UNIVERSIDADE DE SÃO PAULO

INSTITUTO DE GEOCIÊNCIAS

\title{
CARACTERIZAÇÃO DOS GRANULITOS E MIGMATITOS DA REGIÃO DE ALFENAS, MG
}

\author{
Elisa Levatti Alexandre \\ Orientador: Prof. Dr. Renato de Moraes \\ DISSERTAÇÃO DE MESTRADO \\ Programa de Pós-Graduação em Mineralogia e Petrologia
}

São Paulo

2013 
Ficha catalográfica preparada pelo Serviço de Biblioteca e Documentação do Instituto de Geociências da Universidade de São Paulo

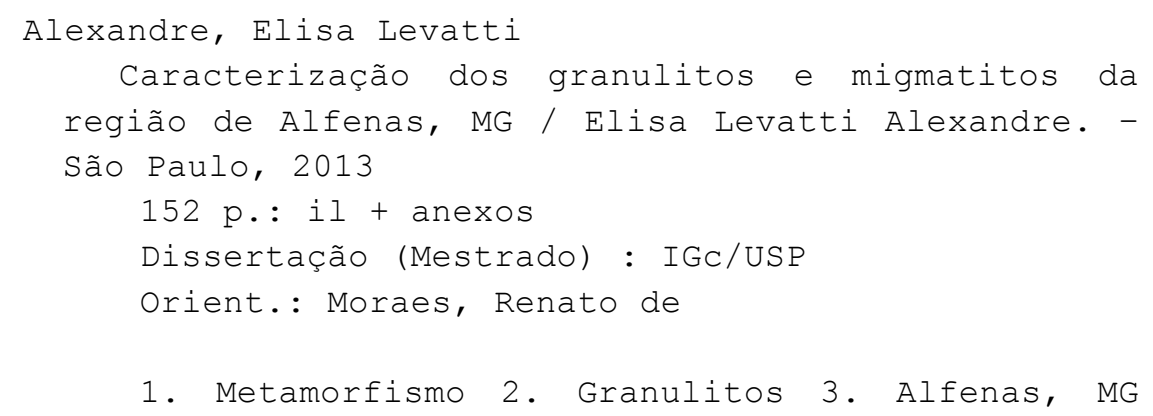




\section{Agradecimentos}

Agradeço a FAPESP, projeto 10/11152-8, pela contribuição na realização de várias etapas dessa dissertação.

A colaboração do Laboratório de Química ICP-OES/MS do GMG-IGc-USP, pelas análises realizadas.

A toda equipe dos laboratórios do Instituto de Geociências (LTA, óptica e laminação) pelas análises realizadas e ao Samuel (Samuca) pela ajuda na preparação das amostras.

Ao laboratório de Microssonda Eletrônica da Universidade Federal do Rio de Janeiro, seus responsáveis e colaboradores por toda compreensão, paciência, disponibilidade e por ajudarem muito na realização das análises.

Agradeço a todos os funcionários do Instituto de Geociências da Universidade de São Paulo, entre eles os seguranças, ao pessoal da limpeza, da gráfica, da biblioteca, da computação, por fazerem parte da minha vida em todos os momentos de geologia.

Aos motoristas Tomás, Marcio, Angelito e Ubiratã pela companhia e por todos os campos que fizemos juntos.

Agradeço a colaboração da Pedreira Santa Terezinha, em Alfenas, Minas Gerais.

Agradeço profundamente ao meu querido orientador prof. Renato, por toda paciência e dedicação, por me dar muitos puxões de orelha e histórias de vida, foram quase sete anos de parceria (não sei como ele aguentou!! Desculpa por fazer seu cabelo cair e ficar branco!!), mas ele me ensinou muito e meu respeito e agradecimento por ele serão eternos.

Agora eu preciso agradecer as pessoas mais importantes na minha vida, que me criaram com carinho, amor, conhecimento, que fizeram de mim o que sou hoje, pela educação e oportunidade de crescimento intelectual e espiritual, que me deram tudo na vida e por ter investido nessa pessoa preguiçosa que sou e mesmo assim acreditaram em mim. Ao meu pai Luiz, minha mãe Gisela, minhas irmãs Paula, Thais e Bio (que é minha terceira irmã, hehehe) e ao novo membro da família, Paulinho, que apesar de não saber o que está acontecendo, já é muito importante e fez parte de tudo isso.

Não posso deixar de agradecer aos meus amigos, que nos momentos mais difíceis me ajudaram a reerguer e continuar! São pessoas maravilhosas, que foram muito importantes na minha vida, pessoas que jamais esquecerei e na qual estou devendo litros de cerveja. A Aline (Massa), ao Claudio (Kabong), Rafaela (Biloba), ao Alex, a Denise, a Ligia (Vesguinha), Andrea (Gê), Luis (Necão), Vinicius (Dispacho), Carlos (Guano), Mariângela (Sabugo), Rodolfo (Lesado), Bruna (Xupix), Saulo (Careca), Barbara, Tábata e ao Prof Carlos.

Agradeço ao Gustavo, pois por ele eu comecei essa jornada da minha vida e se não fosse ele, não teria mudado meu modo de pensar e não teria terminado essa dissertação. Agradeço de coração, pois aprendi muito.

A uma das pessoas mais importantes da minha vida, a minha irmã de coração, Natalia (Spanha), minha amiga, companheira de todas as horas....com ela não tem tempo ruim....vivemos muitas coisas juntas....muitos momentos importantes....e se não fosse por ela talvez eu não tivesse terminado essa dissertação.

E pela pessoa que mudou minha vida nesses últimos meses, a pessoa que me fez redescobrir o amor, as alegrias e as coisas boas da vida, a pessoa que me fez ver um mundo diferente do da geologia, me fez enxergar a realidade e a qual quero passar o resto da vida junto, a pessoa mais maravilhosa desse mundo, o amor da minha vida, João Gabriel. Sem ele não teria conseguido chegar até aqui. 


\section{RESUMO}

Na região de Alfenas, MG, em perfil de norte para sul, a seguinte sucessão de associações de rochas é observada: i) migmatitos, gnaisses e rochas ultramáficas afetados intensamente por zona de cisalhamento; ii) granulitos aluminosos de alta pressão; iii) conjunto de granada granulitos, máficos e félsicos, com lentes ou veios de charnockito e hornblenda-biotita granito, formados por fusão in situ e; iv) unidade de diatexito com paleossoma de hornblenda-biotita gnaisse e granulitos, máficos e félsicos. Essas rochas correspondem, respectivamente, às unidades: Complexo Campos Gerais e às Nappes Três Pontas-Varginha e Socorro-Guaxupé.

As rochas das duas últimas unidades foram afetadas por metamorfismo de fácies granulito, enquanto que os migmatitos e gnaisses do Complexo Campos Gerais sofreram, provavelmente dois episódios de metamorfismo e fusão. As rochas do Complexo Campos Gerais apresentam como paragênese: granada + hornblenda + plagioclásio + feldspato potássico \pm biotita \pm fusão, a qual é representada pelo leucossoma; condições mínimas da transição de fácies anfibolito para granulito são necessárias para formação dessa paragênese, com temperatura de pelo menos $750{ }^{\circ} \mathrm{C}$. Para essas rochas foram feitos cálculos P-T com uma amostra contendo quartzo, plagioclásio, ortoclásio, granada, biotita e hornblenda. Os resultados de pressão são elevados, com valores de 13,3 $\pm 1,4$ kbar e 17,6 $\pm 1,4$ kbar. Para o cálculo de temperatura dois valores muito diferentes foram obtidos, um deles, $560 \pm 166{ }^{\circ} \mathrm{C}$, é baixo demais para as condições de fusão da rocha, e outro com valor é mais apropriado, $835 \pm 185^{\circ} \mathrm{C}$. Alguns dos grãos de feldspato potássico apresentam fraturas e bordas preenchidas por nova geração de feldspato potássico + quartzo + granada, o que pode indicar novo evento de fusão nessas rochas. As disparidades nos resultados de cálculos $P-T$ para as rochas do Complexo Campos Gerais podem ser efeito da dificuldade em definir quais são os minerais do pico metamórfico, quais podem ser relíquias ígneas e quais foram reequilibrados durante o cisalhamento.

Os granulitos aluminosos da Nappe Três Pontas-Varginha apresentam como paragênese cianita + granada + ortoclásio + quartzo + rutilo + líquido (representado pelo leucossoma), indicando pressões mínimas acima de 10,5 kbar e temperaturas entre 850 e $900{ }^{\circ} \mathrm{C}$.

Os granulitos da Nappe Socorro-Guaxupé apresentam duas paragêneses compostas por: i) clinopiroxênio + ortopiroxênio + plagioclásio \pm quartzo e ii) granada + ortopiroxênio + plagioclásio + quartzo + ortoclásio. As paragêneses indicam pressões 
entre 6 e 10 kbar e temperaturas entre $850{ }^{\circ} \mathrm{C}$ e $950{ }^{\circ} \mathrm{C}$. Os resultados dos cálculos indicam que a rocha sofreu metamorfismo de fácies granulito, com pico metamórfico entre 800 a $950{ }^{\circ} \mathrm{C}$ e pressões em torno de 9 a $11 \mathrm{kbar}$, e passou por intenso processo de migmatização e retrometamorfismo tardio em fácies anfibolito.

As rochas da Unidade Diatexítica da Nappe Socorro-Guaxupé apresentam composições provavelmente semi-pelíticas, por apresentarem maior quantidade de fundido muitos cristais de granada. A rocha apresenta como paragênese de pico metamórfico: granada + hornblenda + plagioclásio + feldspato potássico + quartzo. $\mathrm{O}$ campo de estabilidade da rocha varia entre 750 a $950{ }^{\circ} \mathrm{C}$ de temperatura, compatível com a fusão da biotita e hornblenda e as pressões não devem ultrapassar 10kbar, o que é delimitado pela estabilidade da sillimanita, que é o aluminossilicato observado em campo.

As paragêneses contrastantes nos três domínios são reflexos das condições $P-T$ e composição das rochas. Mesmo com grandes incertezas, de modo geral, pode-se dizer que as pressões aumentam de sul para norte, em aumento quase que contínuo entre as rochas da Nappe Socorrro-Guaxupé e Três Pontas-Varginha. Além disso, não há variação termométrica significativa entre as unidades mapeadas, indicando que sofreram o mesmo processo metamórfico e que as variações estruturais encontradas entre elas se dão pela variação composicional, pela porcentagem de água no sistema e pela taxa de fusão de cada uma. 


\section{ABSTRACT}

In the region of Alfenas, $\mathrm{MG}$, in a geologic section from north to south, the following succession of associations of rocks is observed: $i$ ) migmatites, gneisses and ultramafic rocks intensely affected by a shear zone; $i$ ) high-pressure aluminous granulites; iii) a group of garnet granulites, mafic and felsic, with lenses or veins of charnockite and hornblende-biotite granite, formed by in situ melting; iv) unit of diatexite with paleosome composed of hornblende-biotite gneiss of and mafic or felsic granulites. These rocks correspond, respectively, to units: Campos Gerais Complex, Três Pontas-Varginha Nappe and Socorro-Guaxupé Nappe.

The rocks of the last two units were affected by granulite facies metamorphism, whereas the migmatites and gneisses of Complex Campos Gerais suffered, probably, two episodes of metamorphism and partial melting. The rocks of the Complex Campos Gerais present as paragenesis: garnet + hornblende + plagioclase feldspar \pm biotite \pm melting, which is represented by leucosome; minimum $P$ - $T$ conditions are of the transition from amphibolite to granulite facies, which are required for formation of this paragenesis, with a temperature of at least $750{ }^{\circ} \mathrm{C}$. For these rocks, $P-T$ calculations were made with a sample containing quartz, plagioclase, orthoclase, garnet, biotite and hornblende. The results produced high-pressures, with values of 13,3 $\pm 1,4 \mathrm{kbar}$ and $17,6 \pm 1,4$ kbar. For the calculation of temperature, two very different values were obtained, one of them, $560 \pm 166^{\circ} \mathrm{C}$, is too low for the conditions of partial melting for these rocks, and with another one more appropriate, $835 \pm 185^{\circ} \mathrm{C}$. Some of the feldspar grains exhibit fractured edges that are filled with new generation of quartz + feldspar + garnet, which may indicate a new partial melting event. Disparities in outcomes for $P-T$ calculations rocks of Campos Gerais Complex could be the effect of difficult to define what are the metamorphic peak minerals, which may be the igneous relict and which were adjusted during late shearing.

The aluminous granulites of Três-Ponta-Varginha Nappe present as paragenesis kyanite + garnet + orthoclase + rutile + quartz + liquid (represented by leucosome), indicating minimum pressures higher than $10.5 \mathrm{kbar}$ and temperatures between 850 and $900{ }^{\circ} \mathrm{C}$.

The granulites of Socorro-Guaxué Nappe present two parageneses consisting of: i) clinopyroxene + orthopyroxene + plagioclase \pm quartz and $i$ ) garnet + orthopyroxene 
+ plagioclase + quartz + orthoclase. The parageneses indicate pressures between 6 and $10 \mathrm{kbar}$ and temperatures between $850^{\circ} \mathrm{C}$ and $950^{\circ} \mathrm{C}$. Calculation results indicate that the rock has undergone granulite facies metamorphism with metamorphic peak between 800 and $950{ }^{\circ} \mathrm{C}$ and pressures around 9-11 kbar, and went through an intense process of migmatization and later retrogression in amphibolite facies.

The rocks of Diatexite Unit of Socorro-Guaxupé Nappe have probably semipelitic compositions, due to their larger amount of melt and many garnet crystals. The peak metamorphic paragêneses is: garnet + hornblende + plagioclase + quartz + feldspar. The stability field of the rock varies between 750 to $950{ }^{\circ} \mathrm{C}$, temperature compatible with the partial melting of biotite and hornblende and the pressure should not exceed $10 \mathrm{kbar}$, which is delimited by the stability of sillimanite, the aluminumsilicate observed in the field.

The contrasting parageneses in the three areas are reflections of $P-T$ conditions and composition of the rocks. Even with large uncertainties, in general, it can be said that the pressures increase from south to north, almost continuous increase in the rocks of Socorrro Guaxupé Nappe and Três Pontas-Varginha Nappe. Furthermore, no significant thermometric variation between the mapped units, indicating that underwent the same metamorphic process and that structural variations found between that units are given by the compositional variation, the percentage of water in the system and the rate of partial melting of each one. 


\section{Sumario}

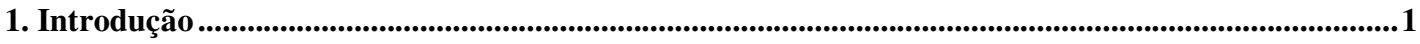

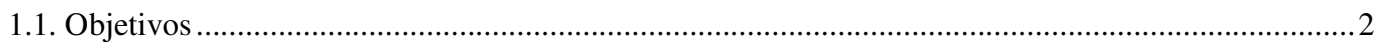

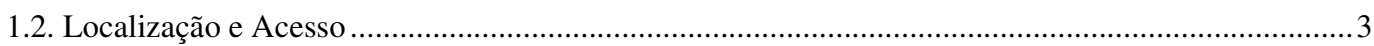

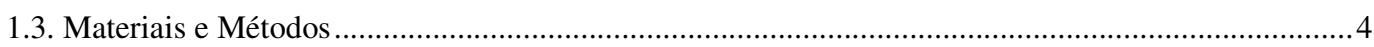

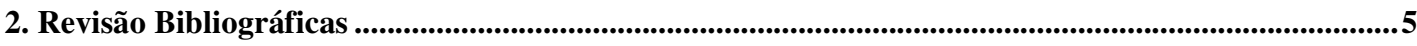

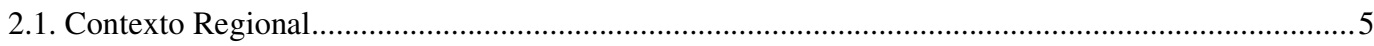

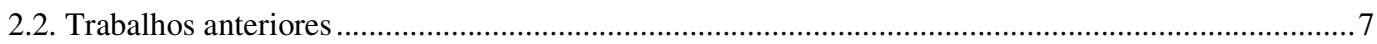

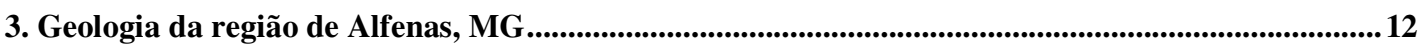

3.1. Unidades do Complexo Campos Gerais............................................................................... 14

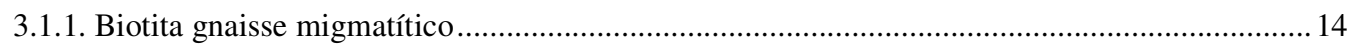

3.1.2. Hornblenda-biotita-granada gnaisse migmatítico ............................................................ 19

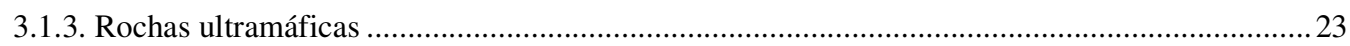

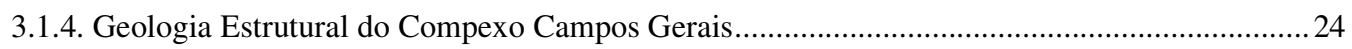

3.2. Unidade da Nappe Três Pontas-Varginha ................................................................................... 25

3.2.1. Geologia Estrutural da Unidade da Nappe Três Pontas-Varginha ........................................ 29

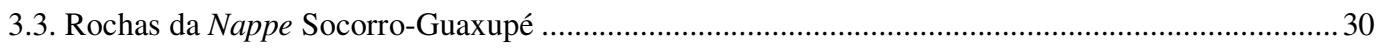

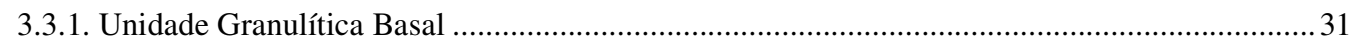

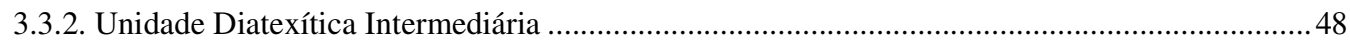

3.3.3. Geologia Estrutural da Unidade da Nappe Socorro-Guaxupé ....................................................52

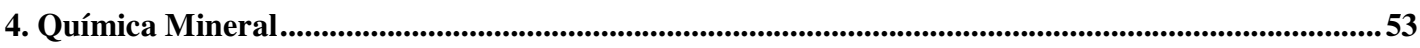

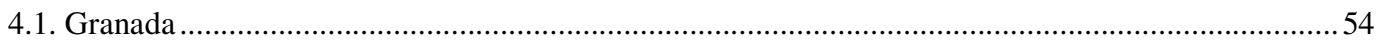

4.1.1. Granada do hornblenda-biotita-granada gnaisse migmatítico do Complexo Campos Gerais ....54

4.1.2. Granada das rochas da Nappe Socorro-Guaxupé ................................................................56

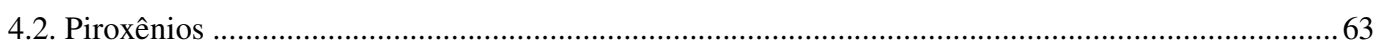

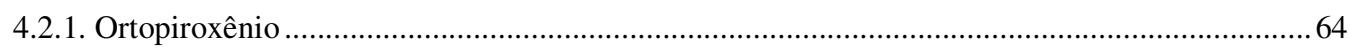

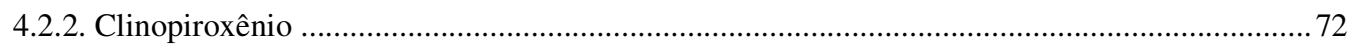

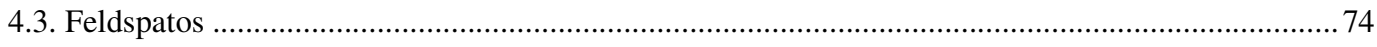

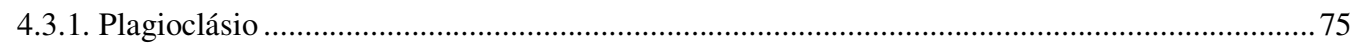

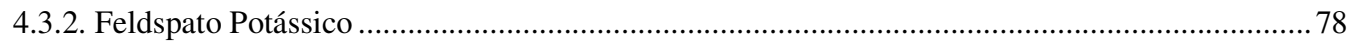

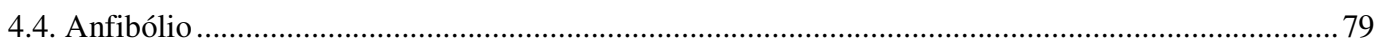

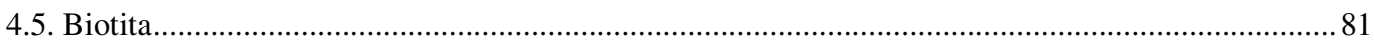

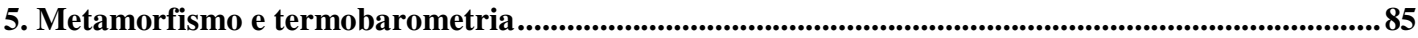

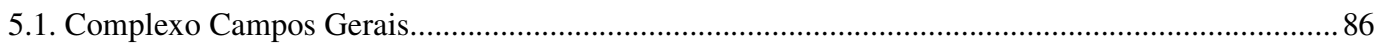

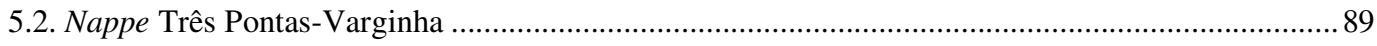

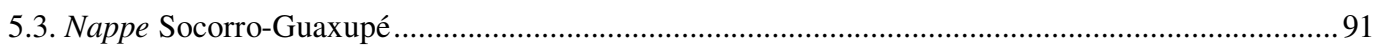

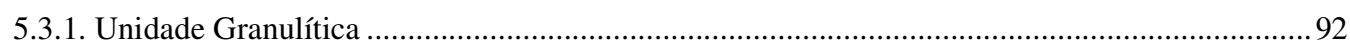

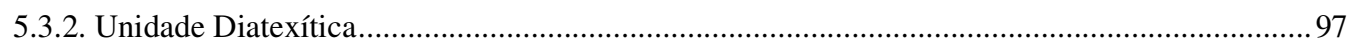

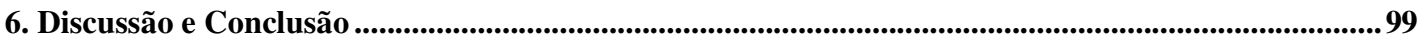

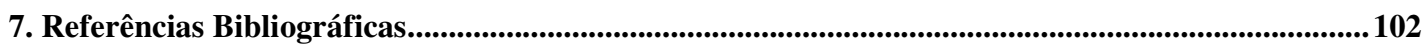

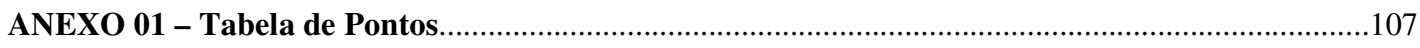

ANEXO 02 - Química Mineral........................................................................................................113

ANEXO 03 - Mapa Geológico e Mapa de Pontos.............................................................................147 


\section{Introdução}

Os granulitos são rochas metamórficas formadas em temperaturas acima de $800^{\circ} \mathrm{C}$, no intervalo amplo de pressão, entre 3 e 16 kbar (Pattison, 2003) e apresentam como mineral índice ortopiroxênio (Behr, et al., 1971). O estudo dos granulitos trás informações sobre a formação e evolução da crosta continental inferior, local em que a maioria dessas rochas é gerada e, consequentemente, ajuda no entendimento dos processos que ocorrem na raiz das cadeias de montanhas. Nesse ambiente há perturbações extremas da geoterma continental gerando intenso magmatismo contemporâneo ao metamorfismo (Harley, 1989). Um dos primeiros trabalhos a relacionar a gênese de granulitos à fusão foi o de Fyfe (1973) e hoje é comum a interpretação de que alguns granulitos félsicos, máficos e aluminosos representam o resíduo sólido, após extração do fundido, aos quais são gerados pelo cruzamento das reações de fusão (Powell \& Downes, 1990; Moraes et al., 2002; White \& Powell, 2002, 2010). Assim, são comuns, em campo, as associações de granulitos, migmatitos, charnockitos e granitos.

Como os granulitos são formados em temperaturas muito altas na crosta terrestre, a sobreposição das condições $P-T$ dos experimentos feitos para calibrações de geotermobarômetros e as da fácies granulito deveria facilitar os cálculos das condições do pico metamórfico dos granulitos. Entretanto, as composições dos minerais sofrem reajustes significativos após o pico metamórfico, em virtude de difusão, exsolução, reações de transferência de rede, ou reação com o fundido aprisionado, dificultando a determinação das condições do pico metamórfico (Frost \& Chacko, 1988; Pattison \& Bégin, 1994; Moraes et al., 2002), o que ocorre pelo resfriamento lento e longo que essas rochas sofrem na crosta média ou inferior.

Na região de Alfenas, em perfil de norte para sul, a seguinte sucessão de associações de rochas é observada: $i$ ) migmatitos, gnaisses e rochas ultramáficas afetados intensamente por zona de cisalhamento; ii) granulitos aluminosos de alta pressão; iii) conjunto de granada granulitos, máficos e félsicos, com lentes de charnockito e hornblenda-biotita granito formados por fusão in situ e; iv) unidade de diatexito com paleossoma de hornblenda-biotita gnaisse e granulitos, máficos e félsicos. Essas rochas correspondem, respectivamente, às unidades: Complexo Campos Gerais e às Nappes Três Pontas-Varginha e Socorro-Guaxupé. 
Os migmatitos e gnaisses do Complexo Campos Gerais não apresentam mineralogia pela qual se possa restringir de maneira simples as condições $P-T$ do metamorfismo, mas grãos de feldspato potássico apresentam fraturas preenchidas por nova geração de feldspato potássico + quartzo + granada, o que indica novo evento de fusão nessas rochas, em pressões relativamente altas, com $T$ de pelo menos $750{ }^{\circ} \mathrm{C}$ (Cavalcante, et al., 1979). Os granulitos aluminosos da Nappe Três Pontas-Varginha apresentam cianita + granada + ortoclásio + quartzo + rutilo, indicando P > 12 kbar e temperaturas mínimas em torno de $850^{\circ} \mathrm{C}$ (Campos Neto \& Caby, 1999, 2000; Garcia \& Campos Neto, 2003). Os granulitos da Nappe Socorro-Guaxupé apresentam paragênese composta de granada + ortopiroxênio + ortoclásio + plagioclásio + quartzo + líquido, o último na forma de leucossoma contendo granada e ortopiroxênio. $T>$ que $900{ }^{\circ} \mathrm{C}$ e $P>$ 10 kbar são necessárias para gerar essa paragênese e fundido com ortopiroxênio + granada (Campos Neto \& Caby, 1999, 2000; Del Lama, et al., 2000).

O presente trabalho visa estudar com mais detalhe as rochas das três unidades e calcular ou estimar as condições $P-T$ do metamorfismo das três unidades para comparálas. Sendo assim, é importante estabelecer as relações texturais, estruturais e metamórficas dessas rochas, e os possíveis processos que as afetaram e suas condições de formação.

\subsection{Objetivos}

O presente trabalho tem por objetivo confeccionar o mapa geológico, em escala 1:100.000, da região de Alfenas, Minas Gerais, enfatizando os aspectos geológicos, estruturais e metamórficos dos diferentes tipos de rochas, do Complexo Campos Gerais (Cavalcante, et al., 1979) e das Nappes Três Pontas-Varginha e Socorro-Guaxupé (Campos Neto \& Caby 1999, 2000). As condições do pico metamórfico serão calculadas para cada unidade, as quais serão comparadas, visando estabelecer o contexto geológico que propiciou o metamorfismo observado. 


\subsection{Localização e Acesso}

A área de estudo está localizada na porção sul do estado de Minas Gerais, englobando a cidade de Alfenas e Fama (Fig. 01).

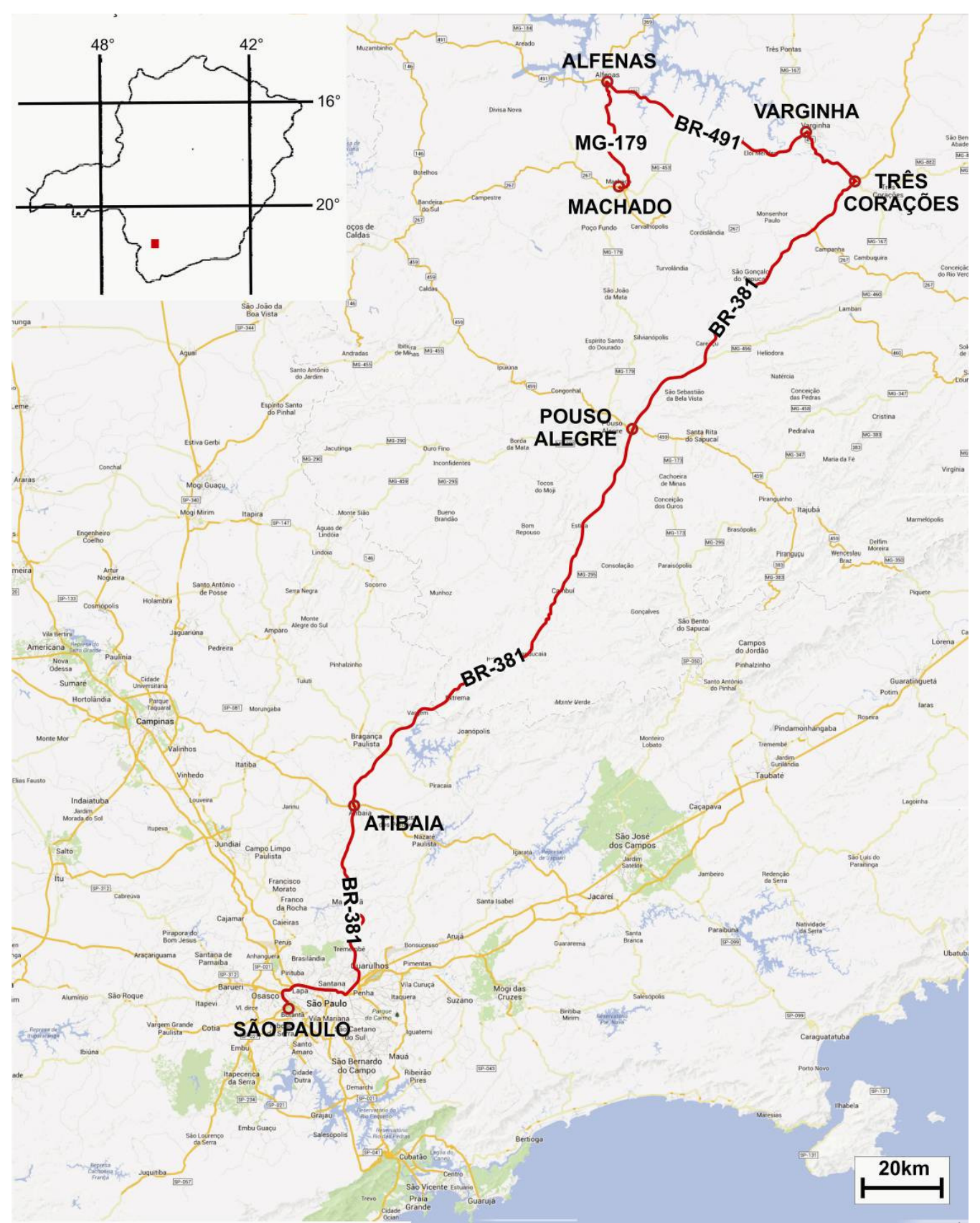

Fig. 01 - Mapa de acesso a área estudada com as principais rodovias e cidades. (modificado de https://maps.google.com.br) 


\subsection{Materiais e Métodos}

Para o desenvolvimento do trabalho foram necessários o levantamento bibliográfico sobre o contexto geológico regional, metamorfismo, termobarometria, associações entre migmatitos e granulitos, fusão, petrografia e química mineral.

Foram realizados quatro trabalhos de campo na região de Alfenas, Minas Gerais, com auxilio de mapas topográficos e geológicos, bússola do tipo CLAR para medidas estruturais, lupa, martelo para coleta de amostras, GPS para localização e caderneta de campo para descrições de afloramentos. Para o mapeamento foram utilizados cartas topográficas, em escala 1:50.000, de Alfenas (SF-23-I-I-3) e Machado (SF-23-I-III-1), fornecidas pelo IBGE - Instituto Brasileiro de Geografia e Estatística. Com os dados coletados pode-se confeccionar um mapa geológico da região em escala 1:100.000 (ANEXO 03). Foram visitados 90 afloramentos, com coleta de 56 amostras de todos os litotipos encontrados na área estudada (ANEXO 01).

Das amostras coletadas, 60 foram serradas, para serem laminadas na Seção de Laminação do Instituto de Geociências da Universidade de São Paulo. Após a petrografia algumas amostras foram selecionadas para que fossem feitas lâminas polidas para serem usadas na microssonda eletrônica.

Petrografia foi usada para separação dos diferentes litotipos, a principio, macroscopicamente, na identificação dos minerais e texturas em 81 seções delgadas (ANEXO 01). Toda petrografia foi executada no Laboratório de Microscopia Petrográfica (LMP) do Instituto de Geociências da Universidade de São Paulo usando o microscópio Zeiss Axioplan de luz transmitida, com câmera fotográfica acoplada para fotomicrografias.

Foram feitas análises químicas de minerais no Laboratório de Microssonda Eletrônica da Universidade Federal do Rio de Janeiro com o equipamento de marca JEOL, modelo JXA-8230, com 5 espectrômetros WDS para análises quantitativas e para análise semi-quantitativa EDS. Os parâmetros usados compreenderam voltagem de aceleração de $15 \mathrm{kV}$, corrente de feixe 20,1 \pm 0,1 nA com padrões de minerais naturais. As seções delgadas polidas para análise na microssonda são confeccionadas no setor de preparação do próprio Laboratório, que conta com equipamentos Logitech e também com metalizador Edwards. 
Os dados de termobarometria foram obtidos através do programa THERMOCALC V.3.26 (Holland \& Powell, 2011). O programa calcula as condições de equilíbrio para cada reação possível, utilizando as atividades dos membros finais das paragêneses em equilíbrio. As atividades dos membros finais foram obtidas com o programa Ax (Holland, 1998). Também foram usados termobarômetros convencionais para comparação de resultados.

O dados coletados para confecção do mapa geológico da região foram tratados pelo conjunto de aplicativos $\operatorname{ArcGIS}^{\circledR}$ v.10 e pela suítes de aplicativos gráficos CorelDRAW-X6 e para o tratamento dos dados estruturais utilizou-se a versão 36 (BETA) do StereoNett.

\section{Revisão Bibliográficas}

\subsection{Contexto Regional}

A Colagem Orogênica Brasiliana é o resultado de sucessão de orogêneses que culminaram na formação do Gondwana Ocidental e pode ser sintetizada em dois sistemas orogênicos maiores, Brasília e Mantiqueira (Fuck et al., 1994; Brito Neves, et al., 1999; Trouw, et al., 2000). A Faixa ou Orógeno Brasília foi também denominada de Tocantins por Campos Neto, 2000. O Orógeno Brasília foi formado entre três blocos continentais: os cratons Amazônico, São Francisco e Paraná e suas rochas registram episódios de subducção e colisão durante o Neoproterozóico (Fuck et al., 1994), envolvendo o fechamento e consumo da crosta do paleo-oceano Goianides, formado pela quebra Toniana do Rodinia (Marangoni, 1994). O Sistema Orogênico Mantiqueira foi formado pela colisão de microplacas e terrenos relacionados ao fechamento do paleo-oceano Adamastor, amalgamado contra a borda oriental do protocontinente formado pelo Orógeno Brasília e o Craton do São Francisco.

O Orógeno Brasília é subdividido em três partes, de leste para oeste: a zona externa, a leste, em que se encontram as coberturas cratônicas sem deformação ou metamorfismo, ou com leve deformação e metamorfismo, principalmente representada pelas rochas do Grupo Bambuí; a Zona interna, formada principalmente pelas rochas do Grupo Araxá e do Complexo Anápolis-Itauçu, além de corpos intrusivos de granitos e gabros. A porção mais a oeste, a zona inferior, é formada pelas rochas do Arco Magmático de Goiás, contendo sequências vulcanossedimentares e rochas ígneas com assinatura juvenil (Fuck et al., 1994). 
Na sua porção sul, denominada de Orógeno Brasília Meridional, as rochas da Nappe Socorro-Guaxupé são equivalentes às do Arco Magmático de Goiás e representam níveis mais profundos da crosta, geradas durante o Cryogeniano Médio, incluindo granulitos e migmatitos diversos, além de corpos graníticos intrusivos. Terrenos metassedimentares metamorfizados em condições de alta pressão ocorrem nas Nappes Três Pontas-Varginha, Carmo da Cachoeira e Aiuruoca-Andrelândia, cujas rochas foram depositadas em ambientes de margem ativa tendo como área fonte depósitos de wacke, sobre fina crosta de antepaís pertencente ao terreno Anápolis-Andrelândia. A maior parte da crosta oceânica e continental da porção oriental desses terrenos foi consumida na subducção (Campos Neto, 2000).

O Orógeno Brasília é formado por dois segmentos, Norte e Sul. As unidades compostas por rochas sedimentares e metassedimentares mostram que a deformação tectônica e o metamorfismo aumentam de leste para oeste, variando de ausência de metamorfismo na porção cratônica que varia até fácies anfibolito e granulito a oeste. A evolução tectônica e metamórfica apresenta vergência do cinturão em direção ao cráton do São Francisco e está marcada por falhas orientadas N-S (Dardene, et al., 2000). O segmento sul é formado pelo Complexo Varginha, que inclui as Nappes Socorro-Guaxupé e Três Pontas-Varginha, e o Grupo Andrelândia composto pelas Nappes Andrelândia, Carmo da Cachoeira, Liberdade e Pouso Alto, klippen Carvalhos, Serra da Natureza, Aiuruoca e o sistema de Nappes Carrancas (Campos Neto, 2000).

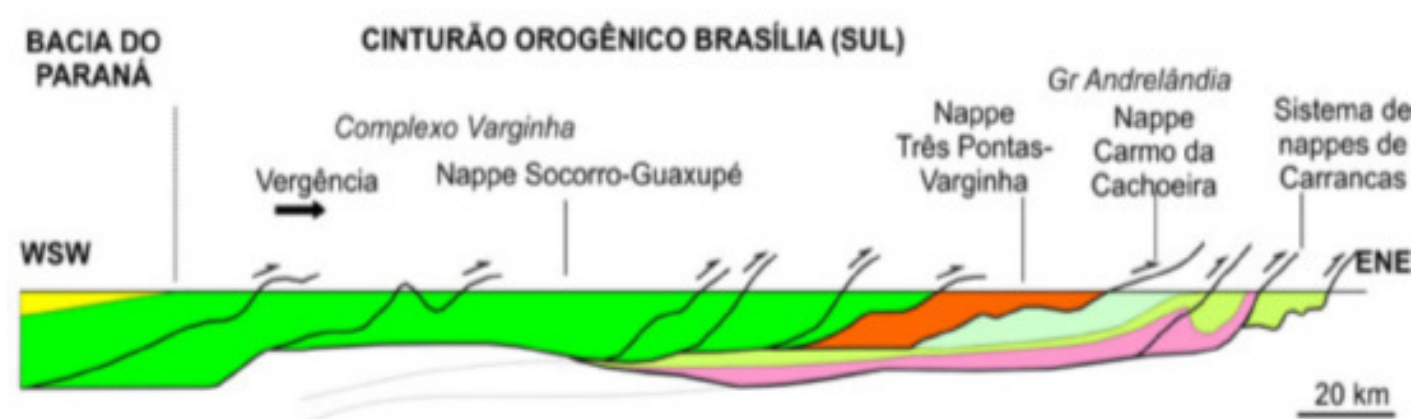

Fig. 02 - Seções simplificadas do conjunto de cavalgamento do Cinturão Brasília (sul). Campos Neto (2000). 


\subsection{Trabalhos anteriores}

Durante o mapeamento de 1:250.000 da folha Varginha Cavalcante et al., (1979) denominaram as rochas pré-cambrianas de Associação Barbacena, que é dividida em Complexos Socorro, Varginha, Paraisópolis, Andrelândia, Amparo, Campos Gerais, Itapira e São João Del Rei.

No extremo sudoeste do Cráton do São Francisco, parte do embasamento Arqueano aflora como um segmento de direção WNW-ESSE, deformado por tectônica neoproterozóica. Este seguimento é conhecido como Complexo Campos Gerais. Determinações U-Pb obtidas por ablação a laser em zircões indicaram idades de cristalização em torno de $2.9 \mathrm{Ga}$ para os ortognaisses, com remobilizações em 2.6 Ga. Populações de zircões herdados sugeriram a presença de uma crosta primitiva com idade máxima de 3.2 a 3.6 Ga (Valeriano et al., 2006). É formado por complexos gnáissicos migmatíticos, ortognaisses de composição granodiorítica a quartzo-granodiorítica, porfiroblásticos ou não, bandados, por vezes miloníticos e hornblenda gnaisses bandados, apresentando enclaves tectônicos de rochas do Grupo Araxá (Cavalcante, et al., 1979).

O Complexo Varginha é constituído por granada-biotita xisto e granada-biotita gnaisse, gnaisses granatíferos, piroxênio granulito, granulito sem piroxênio, rochas calcissilicáticas e dolomito, migmatitos diversos e granitos (Cavalcante, et al., 1979). O Complexo Varginha é separado hoje em Nappes Socorro-Guaxupé, Três Pontas-Varginha e Carmo da Cachoeira, as duas últimas incluindo rochas do Grupo Andrelândia.

Os primeiros estudos sobre o Complexo Varginha foram feitos por Oliveira (1973) que investigou os diversos tipos de gnaisses presentes. Os gnaisses apresentam composição granítica e granodiorítica são os mais comuns, e através de contatos transicionais foram também identificados gnaisse quartzítico e granada gnaisse que gradam para migmatitos. Os migmatitos apresentam uma parte hospedeira, composta por gnaisses escuros e granulitos, o neossoma pode ser granítico, granodiorítico, quartzodiorítico ou pegmatóide. Presença de lentes e boudins de anfibolito e agregados de biotita são comuns no migmatito. A migmatização ocorre em todas as escalas e intensidades, tornando a delimitação das rochas difícil, principalmente a separação de gnaisse verdadeiro de migmatito. Concentrações de biotita nas zonas transicionais entre o biotita gnaisse e o charnockito são comuns. Dados estruturais revelam estrutura geral orientada na direção NW-SE, com ângulos de mergulhos suaves. Granulitos ocorrem associados a 
gnaisses e migmatitos e o processo de migmatização é evento considerado posterior por ter afetado todo o conjunto.

A formação dos granulitos à partir de um conjunto de rochas de natureza calcialcalina diferenciadas foi o primeiro processo efetivo a atingir a região, após a formação de crosta primitiva. Estudos químicos demonstram a natureza trondhjemíticatonalítica tanto dos granulitos como dos migmatitos associados (Oliveira, 1973, Oliveira et al., 1983). Tal processo representou a conjugação de fenômenos magmáticos e metamórficos que atingiram principalmente a base sequenciada do pacote. Nessa porção, além das temperaturas mais elevadas, pode ter ocorrido forte queda da pressão parcial de água, balanceada por aumento da pressão parcial de $\mathrm{CO} 2$, explicando a mineralogia anidra típica dessas rochas como sugerido em trabalhos de Newton et al. (1980) ou Touret (1974).Nessas condições a água poderia se concentrar nas partes superiores do pacote, favorecendo o desenvolvimento de processos de anatexia com formação de leucossoma e explicando a presença de rochas charnockíticas e graníticas em contatos gradacionais. Nova fase de anatexia regional afetou o conjunto de rochas da região, resultando na formação de migmatitos de injeção caracterizados por leucossoma róseos pegmatíticos e aplíticos. Reações entre rochas graníticas e charnockíticas podem ter sido acentuadas nessa fase, com os materiais granulíticos perdendo suas feições típicas e assumindo coloração e mineralogia de tipos graníticos (Oliveira, 1973; Cavalcante et al., 1979).

Duas fases de metamorfismo são identificadas, a mais antiga de fácies granulito e a segunda de fácies anfibolito com temperaturas em torno de 660 a $715{ }^{\circ} \mathrm{C}$. Corpos de gnaisses próximos dos granulitos apresentam temperaturas de metamorfismo em torno de 800 e $840{ }^{\circ} \mathrm{C}$ e pressões inferiores a $8 \mathrm{kbar}$, indicando condições da fácies granulito (Oliveira \& Ruberti, 1979).

Dentro da Associação Guaxupé, foram descritas rochas granulíticas que variam de máfica-ultramáficas até félsicas, chegando a termos hololeucocráticos, de tal forma que pode estabelecer sequência com granulitos máficos na base e félsicos no topo (Oliveira, 1984). Tectonicamente os tipos félsicos estão empurrados por sobre os tipos máficos. Incluídas nesse pacote encontram-se rochas de natureza supracrustal, representadas por quartzito, mármore, rochas calciossilicatadas e eventualmente kinzigitos, que não ultrapassam $10 \%$ do total das rochas observadas para essa área. A maior concentração de granulitos encontra-se na porção norte da unidade, onde tipos de composição gabronorítica apresentam-se intercaladas com tipos de composição enderbítica ou ainda 
mais rica em quartzo. Na porção sul da unidade, os granulitos passam a constituir corpos isolados, rodeados por migmatitos de estruturas diversas, com contatos gradacionais, parecendo constituir restos não atingidos pelo processo de migmatização, enquanto os tipos ricos em quarto, de coloração rósea, passam a se confundir com migmatitos de estruturas evoluídas. Os migmatitos que dominam a porção sul apresentam composição tonalítica, com bandas escuras diorítica e leucossoma granodiorítico a granítico (Oliveira, 1973, Oliveira \& Alves 1974, Oliveira et al., 1983).

Posteriormente, granulitos e migmatitos foram reunidos sob a denominação de Nappe Socorro-Guaxupé, lasca neoproterozóica composta por três unidades de crosta continental profunda: a unidade Granulítica Basal, a Diatexítica Intermediária e a Migmatítica Superior (Campos Neto \& Caby, 2000) (Fig. 03). A porção basal é formada por granada-biotita-ortopiroxênio granulito bandado com intercalações de gnaisse gabronodiorítico e faixas descontínuas de ortognaisse migmatítico de composição tonalito-granodiorito no topo da unidade. Na unidade intermediária são ocorrem biotitagranada diatexito granítico rosado (Haddad et al., 1997; Janasi, 1997a), derivado da fusão por quebra da biotita de fontes metaluminosas a peraluminosas. Encraves metassedimentares ocorrem como faixas de kinzigito. $\mathrm{O}$ migmatito estromático da unidade superior apresenta mesossoma com assinaturas químicas e isotópicas de metagrauvaca e de metapelito oriundos da denudação do arco magmático neoproterozóico (Janasi, 1999).

Intenso magmatismo ocorreu em diferentes níveis da pilha da Nappe, onde os corpos mais profundos são derivados da fusão de granulitos. Nos níveis intermediários dominam granitóides híbridos derivados da fusão da crosta inferior, com participação de rochas máficas e com assinaturas de zonas de subducção. Os batólitos mais rasos formam série calcioalcalina de composição peraluminosa, gerados por fusão com a quebra da muscovita (Campos Neto et al., 1988; Janasi, 1997a, b, c). 


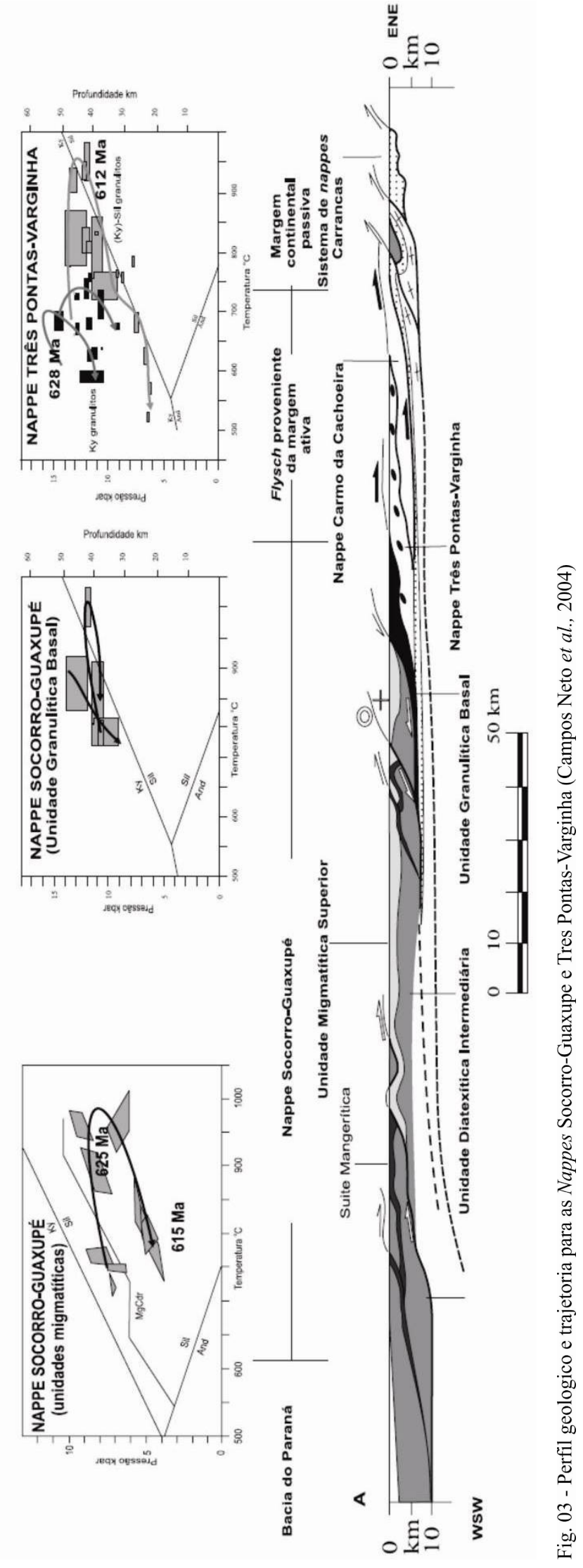


As unidades exibem foliação metamórfica de baixo ângulo e metamorfismo de temperatura ultra-alta, determinado com dados termobarométricos. Os indicadores cinemáticos indicam movimento de topo para ENE dos cavalgamentos. As unidades superiores registram trajetória metamórfica que atinge condições máximas de $800{ }^{\circ} \mathrm{C}$ e 7,5 kbar. Condições de mais alta pressão estão registradas na unidade granulítica basal, com temperaturas de $775-870{ }^{\circ} \mathrm{C}$ e pressão de 9 - $14 \mathrm{kbar}$, respectivamente (Del Lama et al., 2000; Campos Neto \& Caby, 2000; Freitas, 2000; Garcia \& Campos Neto, 2003). Este cenário metamórfico é compatível com ambiente tectônico relacionado à raiz profunda de arco magmático (Campos Neto et al., 2004).

A geoquímica isotópica indica que houve mistura de material neoproterozóico com crosta continental mais antiga, sugerindo que a frente da Nappe Socorro-Guaxupé represente o segmento adelgaçado da Placa Paranapanema, em virtude da menor contaminação de crosta antiga. Idades de zircão registram valores de até 670 Ma para a atividade de arco controlada por subducção, com metamorfismo e plutonismo de até 625 Ma. O equilíbrio metamórfico, associado ao relaxamento térmico colisional, ocorreu entre $615 \pm 16$ Ma e $612 \pm 3$ Ma. As condições do metamorfismo dos granulitos atingiram 740 $\pm 10{ }^{\circ} \mathrm{C}$ e $9 \pm 1,2$ kbar e nos migmatitos $750{ }^{\circ} \mathrm{C}$ e $5,5 \mathrm{kbar}$, respectivamente das unidades do granulito basal e migmatito superior. As idades para os granitos meta e peraluminosos, sin- a tardi-colisionais estão entre $619 \pm 4$ e $604 \pm 10$ Ma. Como a deformação das rochas plutônicas ocorreu em estado sólido, admite-se idade de $615 \mathrm{Ma}$, quando ocorreu o principal período de transporte da Nappe (Campos Neto et al., 2004). 


\section{Geologia da região de Alfenas, MG}

A partir do mapeamento na região de Alfenas, $\mathrm{MG}$, foi elaborado o mapa geológico em escala 1:100.000 (ANEXO 03). Em perfil geológico de norte para sul as seguintes associações litológicas são reconhecidas: $i$ ) migmatito, gnaisse e rochas ultramáficas afetados intensamente por zona de cisalhamento; ii) granulito aluminoso com paragêneses de alta pressão; iii) conjunto de granada granulitos, máficos e félsicos, com veios e lentes de charnockito e hornblenda-biotita granito formados por fusão in situ e; iv) unidade dos diatexitos com paleossoma de hornblenda-biotita gnaisse intercalado com lentes de granulito máfico e félsico. Essas rochas correspondem, respectivamente, ao conjunto empilhado de rochas metamórficas, definido por Cavalcante (1979), Garcia (2001), Campos Neto \& Caby (2000) e Campos Neto et al. (2004) como Complexo Campos Gerais (i), Nappe Três Pontas-Varginha (ii) e às Unidades Basal (iii) e Intermediária (iv) da Nappe Socorro-Guaxupé. Todas as unidades apresentaram foliação principal $\left(S_{2}\right)$ de alto grau, marcada por minerais como piroxênio, quartzo, feldspato, entre outros.

A região apresenta afloramentos com relativo distanciamento entre os mesmos. Foram visitados 91 afloramentos, todos com a sigla ALFE, seguido do número do afloramento, onde 111 amostras foram coletadas para análise (ANEXO 01). Os principais tipos de afloramentos foram de cortes de estradas frescos a muito intemperizados, blocos e lajedos no meio de plantações/pastos e pedreiras abandonadas e/ou em atividade (Fig. 04).

Durante os trabalhos de campo foram coletados dados estruturais de foliação, lineação, eixo de dobras e seus planos axiais, envolvendo descrição e análise das relações geométricas e cinemáticas das estruturas e de suas atitudes. Para essas análises foi utilizada bússola do tipo CLAR, porém, no texto as atitudes foram apresentadas em notação de azimute (com exceção das tabelas do Anexo 01). Os dados foram tratados em estereogramas e plotados no mapa geológico (Anexo 03). Os pólos das atitudes foram plotados em estereogramas usando a projeção no hemisfério inferior em rede de equal area de Schmidt-Lambert. 

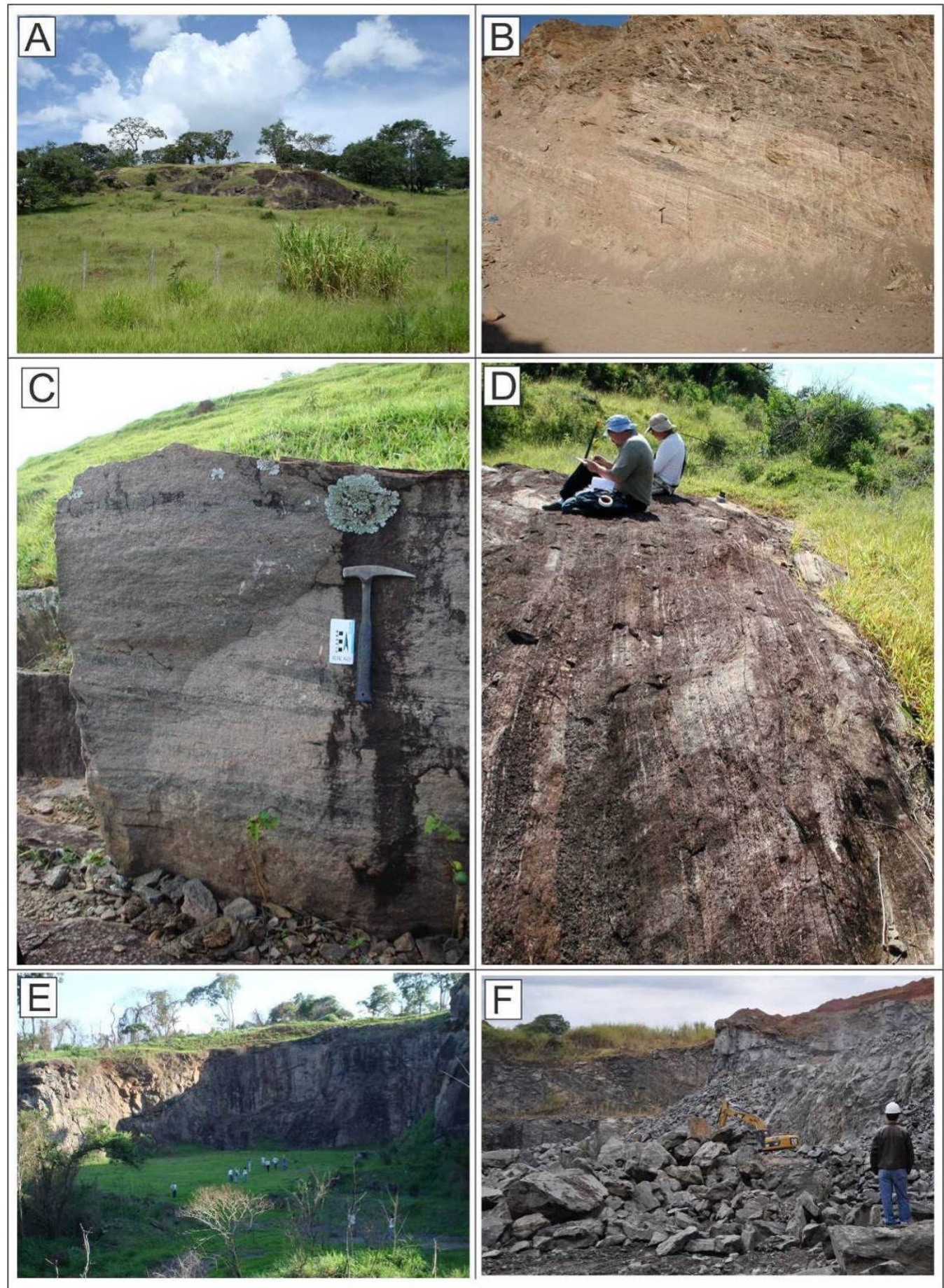

Fig. 04 - Foto dos tipos de afloramentos encontrados na região estudada. Em (A) rochedo e blocos no meio do pasto, podendo a rocha ser fresca ou intemperizada, ALFE26; (B) corte em mina de saibro, muito alterado, mas que ainda é possível observar algumas estruturas na rocha, ALFE59; (C) matacão/bloco cortado para fabricação de paralelepípedos, ALFE40; (D) lajedo de rocha fresca a pouco alterada, em que as camadas mais resistentes se sobressaem deixando mais evidentes estruturas como a foliação, dobras e boudins, ALFE22; (E) mina de brita abandonada, ALFE71; (F) mina Santa Terezinha, em atividade, ALFE45. 


\subsection{Unidades do Complexo Campos Gerais}

As rochas do Complexo Campos Gerais são divididas em dois tipos: biotita gnaisse migmatítico e hornblenda-granada-biotita gnaisse migmatítico, os quais são separados por uma camada de $\pm 5 \mathrm{~m}$ de espessura de muscovita-biotita xisto, o que indica a presença de zona de cisalhamento mais intensa, provavelmente com entrada de água no sistema causando a quebra da biotita e feldspatos e o aparecimento de muscovita. Alguns afloramentos de rocha ultramáfica apresentam-se encaixados esparsamente na porção sul da unidade.

\subsubsection{Biotita gnaisse migmatítico}

O biotita gnaisse migmatítico apresenta cor cinza escura com porções branca amareladas, com exposição mais comum na forma de lajedos e matacões com graus variados de alteração. A rocha apresenta foliação e bandamento composicional preservado, variando de milimétrico a centimétrico $(<20 \mathrm{~cm})$, com bandas quartzofeldspáticas, bandas máficas e bandas de composição intermediária, que sofreram intensa deformação, evidenciada pela presença de feições miloníticas e estruturas de cisalhamento como porfiroclastos de quartzo-feldspato sigmoidais formando pares $S C$ com movimento sinistral com topo para NW e a presença de feições de deformação como dobras do tipo parasitas, intrafoliais e/ou pitigmáticas e boudins. As dobras apresentam charneiras variando de arredondadas a agudas e espessadas, flancos estirados e adelgaçados e nas bandas mais ricas em biotita há concentração das mesmas entre as charneiras formando bolsões, ou entre os flancos onde a camada afina e desaparece. Apresenta granulometria heterogênea, textura variando de granoblástica, protomilonítica a milonítica, marcadas por intensa recristalização do quartzo e por porfiroclastos de feldspato (Fig. 05).

A rocha é composta por quartzo (25-30\%), feldspato (25-35\%) onde a maior parte é plagioclásio An27, oligoclásio, e em menor proporção microclínio e ortoclásio, biotita $(15-30 \%)$, muscovita $(5 \%)$, epidoto $(<2 \%)$, minerais opacos $(<5 \%)$, illmenita, pirita e magnetita, e minerais acessórios $(<1 \%)$, tais como zircão, monazita e apatita.

Os grãos de quartzo e feldspato são os mais abundantes na rocha, encontram-se distribuídos na matriz ou na forma de bandas com espessura de até $20 \mathrm{~cm}$, contínuas ou descontínuas, paralelas à foliação principal ou formando dobras. Apresenta granulação 
heterogênea variando de muito fina a muito grossa $(\sim 0,01-3,0 \mathrm{~mm})$, textura granoblástica e milonítica, com grãos de até $4,0 \mathrm{~cm}$.
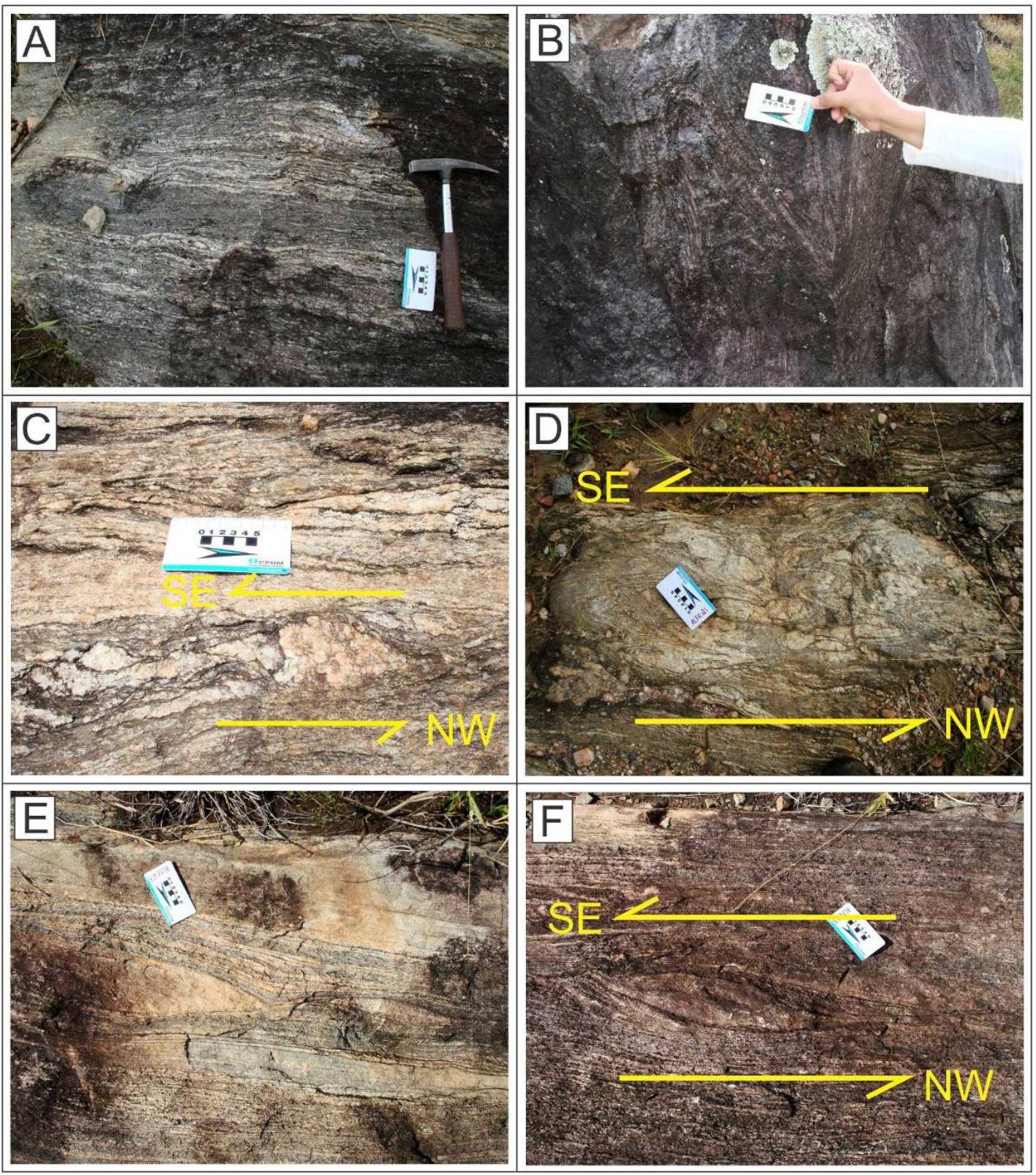

Fig. 05 - Foto do afloramento ALFE04 em A e B e ALFE23 em C, D, E e F. Em A, bandamento composicional migmatítico; em $\mathrm{B}$, dobras intrafoliais com eixo paralelo a foliação principal; em $\mathrm{C}$, porfiroclasto de feldspato sigmoidal com movimento sinistral para SE; em D, dobras pitigmáticas com eixo axial paralelo a foliação principal; em $\mathrm{E}$, boudins de leucossoma sigmoidais com movimento sinistral para NW/SE; em F, detalhe do menor boudin da foto E, indicando melhor o movimento sinistral. 
Os porfiroclastos de feldspatos formam sigmóides com movimento sinistral de topo para NW e apresentam bordas recristalizadas, os veios de quartzo apresentam-se estirados segundo a foliação principal, contendo grãos com extinção ondulante, porém na matriz, ambos, quartzo e feldspato, apresentam-se subidioblásticos a xenoblásticos, com contatos lobados a interdigitados, em alguns casos é possível observar relíquias de contatos poligonizados, mas a rocha sofreu intenso processo de migmatização e é muito comum feições de fusão como quartzo e feldspatos intersticiais a grãos maiores, gotículas de quartzo entre os grãos formando string beads, estruturas em mosaico e mirmequitas (Fig. 06). A maioria das estruturas podem ser confundidas com estruturas de cristalização e não de fusão, dificultando a exibição das mesmas em fotomicrografias.
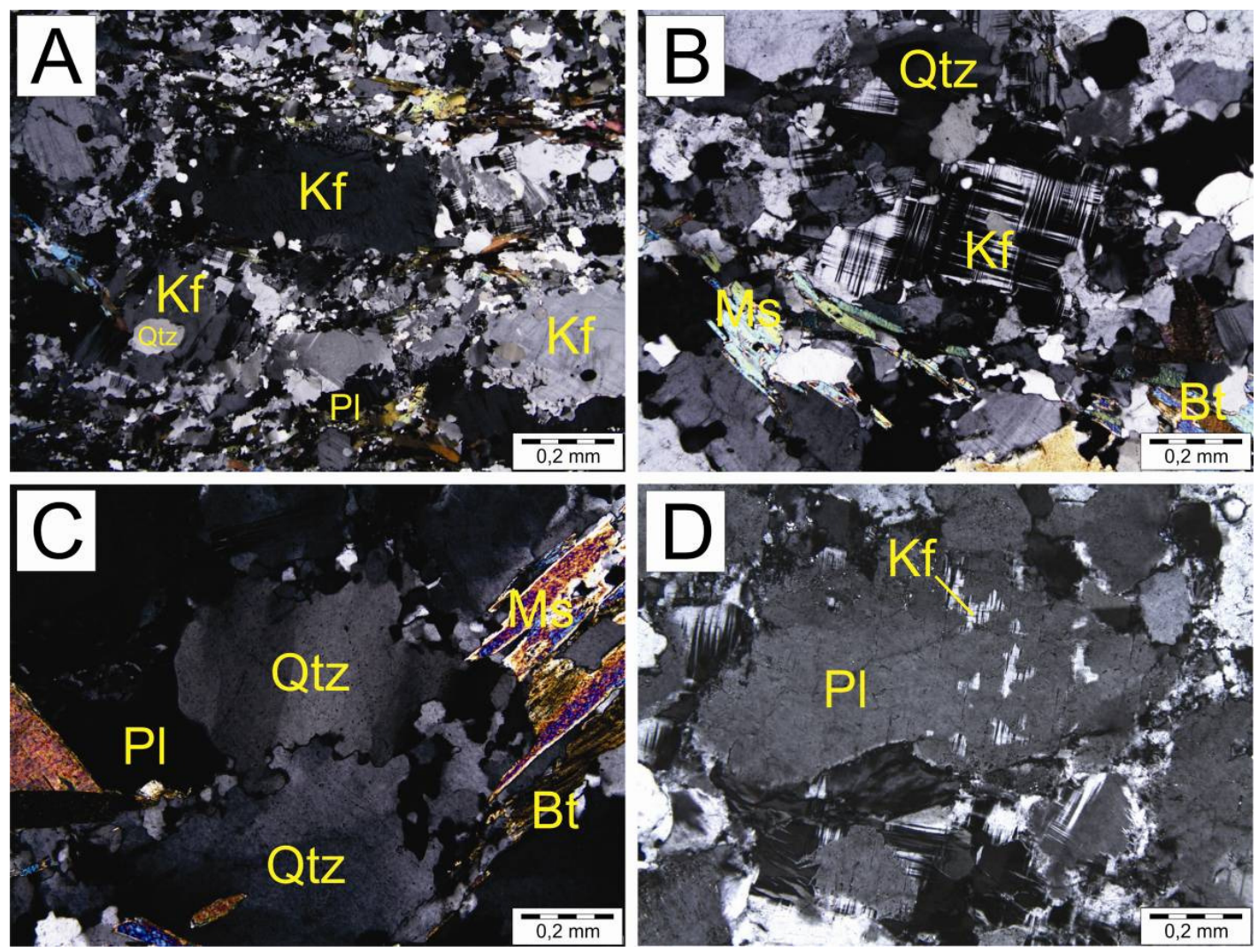

Fig. 06 - Fotomicrografia da lâmina ALFE22a, do Complexo Campos Gerais. Em A, cristal de feldspato potássico reliquiar com borda recristalizada, alguns cristais de quartzo goticulares ao redor do feldspato formam string beads; em $\mathrm{B}$, feldspato potássico com bordas irregulares com quartzo e feldspatos intersticiais aos grãos maiores, formando string beads; em C, quartzo com bordas carcomidas indicando migração de borda agregando cristais menores de quartzo; em D, lamelas de feldspato potássico em plagioclásio, indicando desequilíbrio. A, B, C e D com polarizadores cruzados. Todas as abreviações segundo Kretz (1983). 
A biotita é o mineral máfico mais comum na rocha, principalmente nas bandas mais máficas (melanossoma) e intermediárias. Apresenta cor marrom a verde pardo, com granulação fina a muito fina $(\sim 0,01-0,25 \mathrm{~mm})$, encontra-se orientada segundo a foliação principal, com grãos entrelaçados entre os grãos de quartzo e feldspato da matriz, gerando textura grano-lepidoblástica, ou pode marcar também outros eventos indicados por leves crenulações. Apresenta inclusões de zircão e monazita e em alguns casos foi transformada por muscovita, durante o retrometamorfismo. A muscovita apresenta-se associada à biotita, geralmente substituindo-a, apresenta granulação muito fina ( 0,01-0,125 mm) e é um dos minerais que compõe a foliação principal da rocha (Fig. 07).

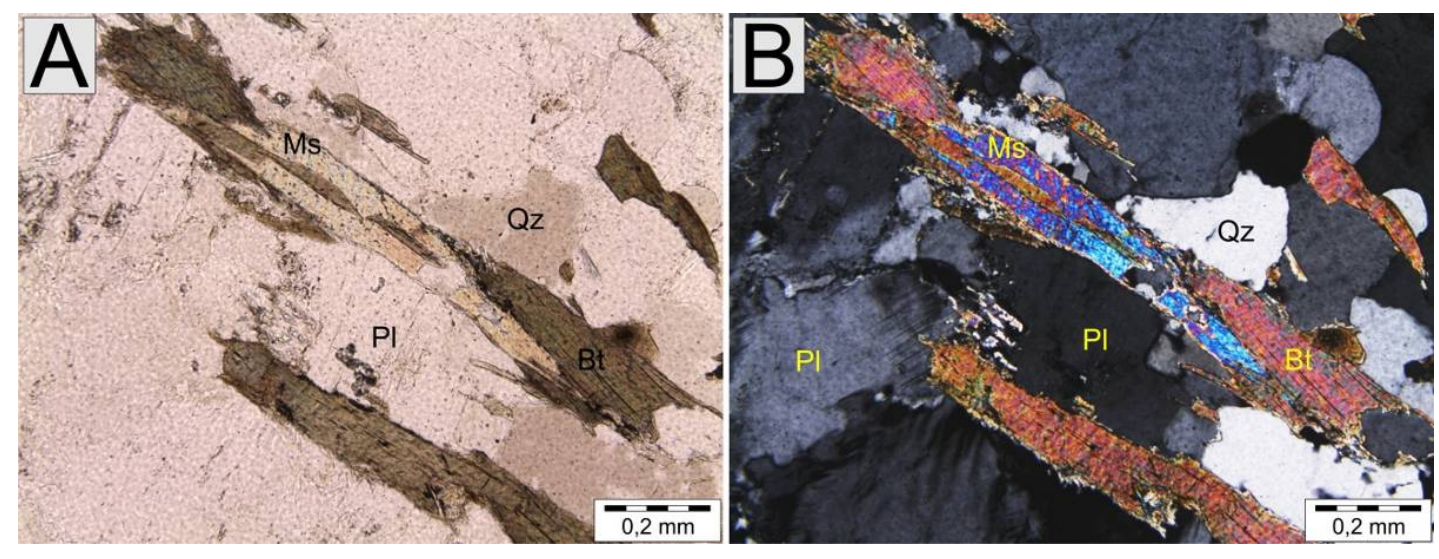

Fig. 07 - Fotomicrografia da lâmina ALFE22a, onde biotita ocorre passando para muscovita. Polarizadores paralelos (A) e cruzados (B).

O epidoto é raro na rocha, sempre associado à apatita ou feldspato, como produto de alteração (Fig. 08). É incolor a levemente amarelado, com granulometria muito fina $(<0,001 \mathrm{~mm})$, com formas e contatos irregulares. Os minerais acessórios como zircão, apatita e monazita, geralmente são arredondados ou euedrais, de granulação muito fina ( 0,001-0,01), podendo ser encontrados dispersos na matriz ou inclusos em outros minerais, e estão distribuídos regularmente por todas as bandas. 


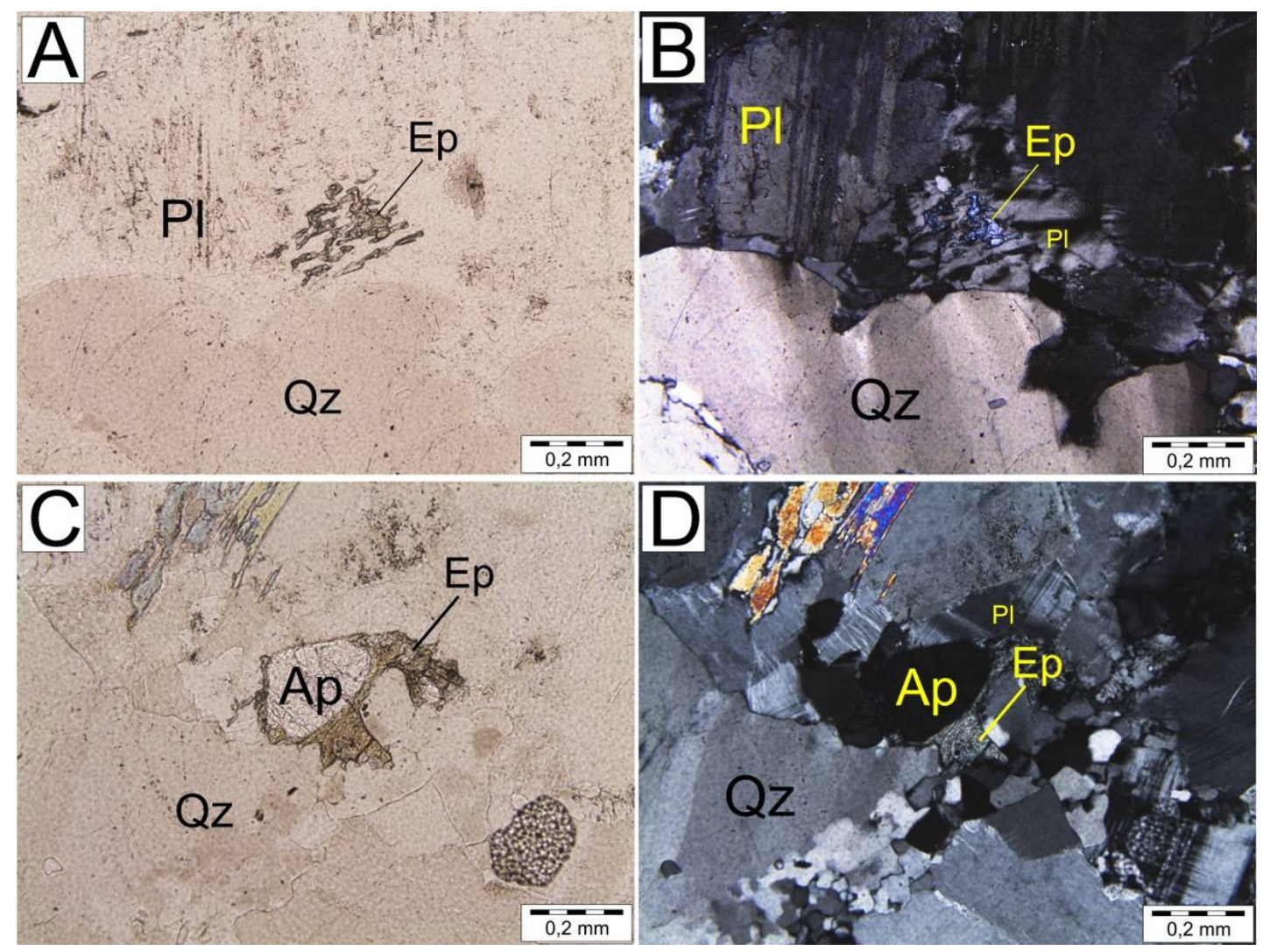

Fig. 08 - Fotomicrografia da lâmina ALFE22a polarizadores paralelos a direita e cruzados a esquerda. Relação do epidoto na rocha. No primeiro caso (A e B) ocorre como alteração do feldspato, no segundo caso (C e D) substitui a apatita.

A Tabela a seguir apresenta a sequência de cristalização e blastese da rocha.

\begin{tabular}{|l|c|c|c|}
\hline Minerais & Pré-deformação & Sn & Pós-deformação \\
\hline Quartzo & & & \\
\hline Feldspatos & & ---------------- & \\
\hline Biotita & & & \\
\hline Muscovita & & & \\
\hline Epidoto & & & \\
\hline
\end{tabular}




\subsubsection{Hornblenda-biotita-granada gnaisse migmatítico}

O hornblenda-biotita-granada gnaisse migmatítico apresenta cor cinza claro, com exposição na forma de matacões e blocos, com variados níveis de alteração. Apresenta foliação definida por biotita, hornblenda, quartzo e feldspatos, cortada por bolsões irregulares de leucossoma, que agregam porções da parte foliada, indicando fusão posterior à deformação, embora alguns veios de leucossoma sejam paralelos à foliação principal gerando bandamento composicional. Nessa rocha só é possível identificar leuco e mesossoma (paleossoma), com evidências de fusão incipiente distinguindo esse migmatito como sendo patch migmatite (Sawyer, 2008) (Fig. 09).

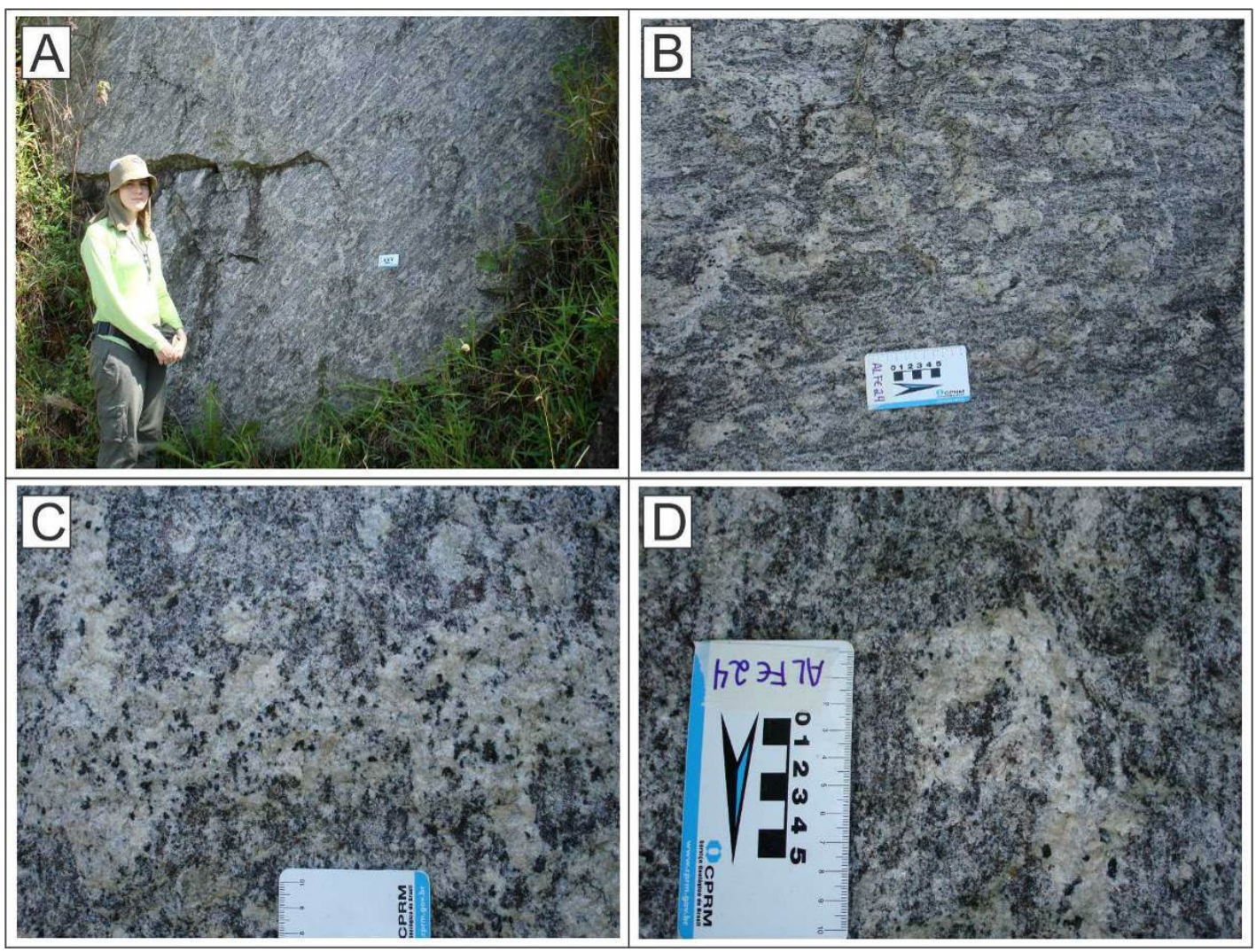

Fig. 09 - Foto do afloramento ALFE24, Complexo Campos Gerais. Em A e B porções de leucossoma cortando e paralelo a foliação; em C evidência de fusão insipiente como o bolsão de leucossoma cortando a foliação com cristais de hornblenda agregados durante a fusão e recristalizados; em D leucossoma cortando a foliação agregando pedaços da rocha hospedeira.

O leucossoma é composto por quartzo ( 20-30\%), feldspatos ( 30-40\%), principalmente microclínio e ortoclásio, com presença de plagioclásio An28, oligoclásio, 
em menor quantidade, hornblenda $(\sim 10-15 \%)$ e granada $(\sim 5-10 \%)$. Apresenta granulação média a grossa $(0,2$ a $3,0 \mathrm{~cm})$, textura granoblástica e porfiroblástica gerada por cristais de até $3,0 \mathrm{~cm}$ de hornblenda. O mesossoma é composto por quartzo ( 10-20\%), feldspatos ( 20-35\%), microclínio e plagioclásio, An28, oligoclásio, hornblenda ( 20$25 \%)$, biotita $(\sim 5-15 \%)$, granada $(\sim 10-25 \%)$, allanita $(\sim 3-5 \%)$, minerais opacos $(<5 \%)$ e minerais acessórios $(<5 \%)$, tais como titanita, rutilo, zircão, epidoto e apatita. Apresenta granulação heterogênea variando de fina a grossa $(0,01-7,0 \mathrm{~cm})$, com textura lepidogranoblástica a nematogranoblástica dependendo do predomínio de biotita ou hornblenda orientada; localmente a deformação é mais intensa e ocorrem porfiroclastos $(\sim 4,0-6,0 \mathrm{~cm})$ de feldspatos com formatos sigmoidais orientados segundo a foliação principal. Alguns desses porfiroclastos apresentam coronas de granada ou biotita. O contato entre o leucossoma e o mesossoma é abrupto e em algumas porções forma selvedge de hornblenda e/ou granada (Fig. 10).

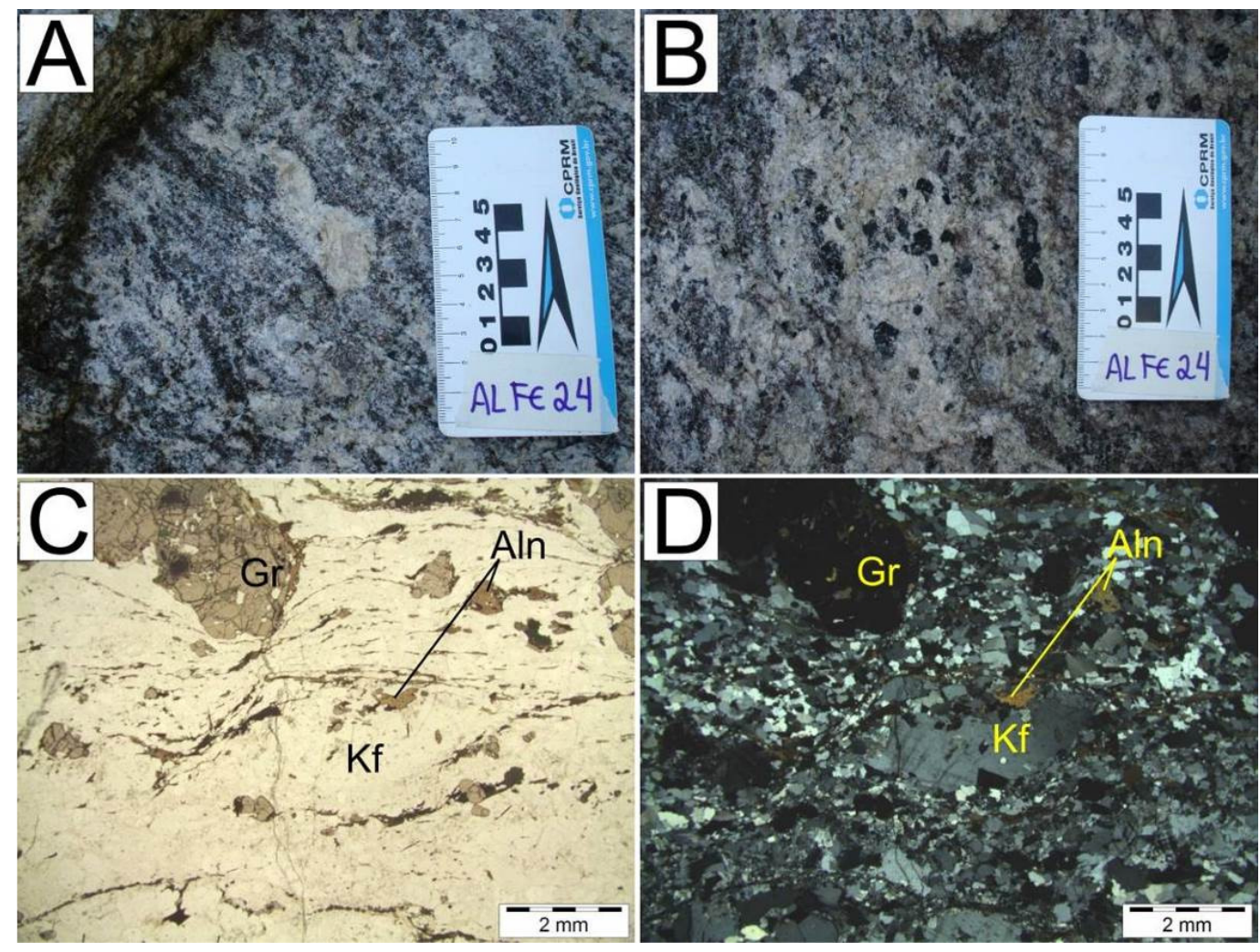

Fig. 10 - Foto do afloramento ALFE24 (A e B) com detalhe de megacristal de feldspato com corona de hornblenda e granada em A e resto de paleossoma no meio de leucossoma em B; em C e D, fotomicrografia da lâmina ALFE24d com polarizadores paralelos na primeira e cruzados na segunda, onde é nítido porfiroclasto reliquiar de feldspato potássico com bordas recristalizadas. 
A hornblenda é mais comum no mesossoma, marcando a foliação principal, e pode ser encontrada no leucossoma em menor quantidade, na forma de fenocristais euédricos desorientados. Apresenta cor verde claro a escuro, com granulação heterogênea $(\sim 0,01 \mathrm{~mm}$ a $3,0 \mathrm{~cm})$. O mesossoma apresenta-se subidioblástica, com contatos arredondados a angulosos e com inclusões de biotita, zircão e quartzo. Em algumas porções substituiu parcialmente granada ou biotita (Fig. 11).

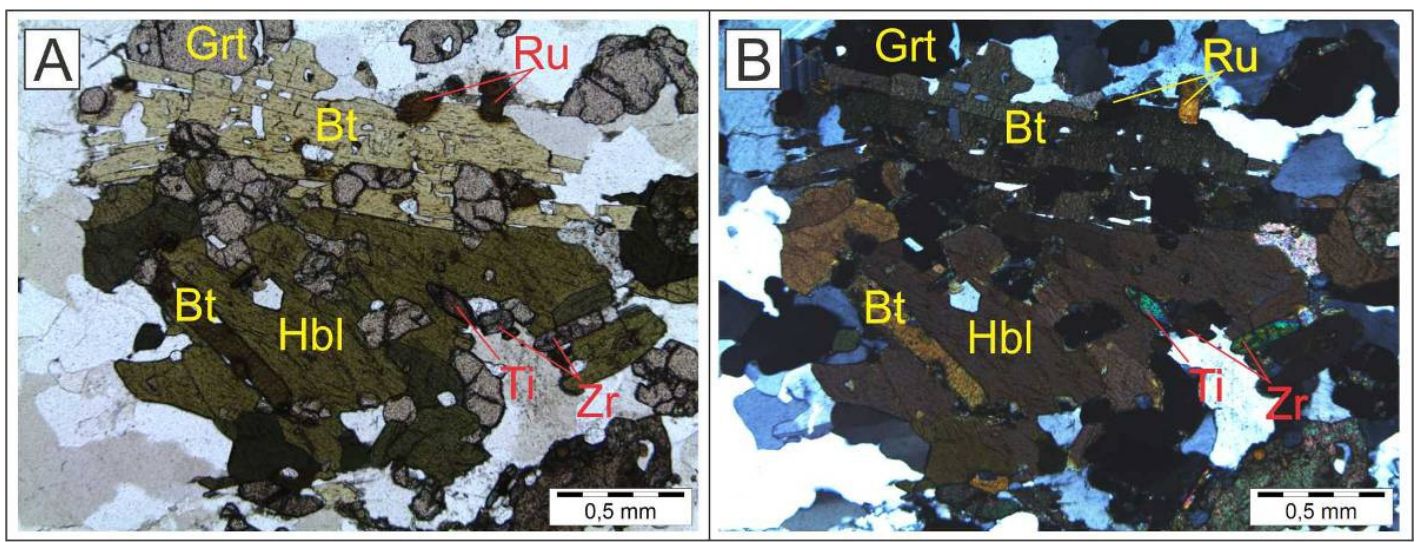

Fig. 11 - Fotomicrografia da lâmina ALFE24e com as relações entre hornblenda e biotita, onde a hornblenda substitui a biotita e a granada. Detalhe para os diversos acessórios como zircão, titanita e rutilo (polarizadores paralelos e cruzados respectivamente).

A granada, presente no leuco- e no mesossoma, apresenta coloração rosada e granulometria fina $(\sim 0,5-1,0 \mathrm{~mm})$, é poiquiloblástica com inclusões de epidoto, na forma de prismas, quartzo e feldspatos arredondados, micas e minerais opacos. Apresenta bordas e formatos irregulares, às vezes forma aglomerados de grãos arredondados e sem inclusões. Em algumas porções encontra-se substituída por hornblenda e biotita e pode formar coronas nos grãos de feldspato do mesossoma (Fig. 12).

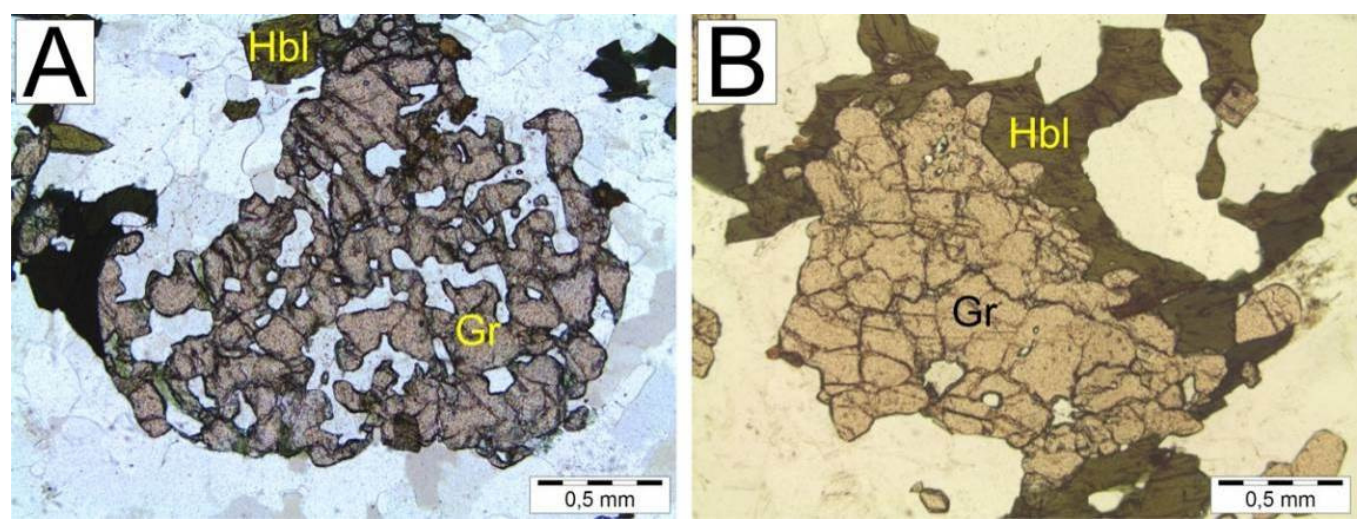

Fig. 12 - Fotomicrografias com polarizadores paralelos a esquerda e cruzados a direita. Em A, lâmina ALFE24b, granada poiquiloblástica com inclusões de quartzo e feldspato e em B, lâmina ALFE24e, granada sendo substituída por hornblenda. 
A biotita define a foliação principal, entrelaçando-se entre os grãos de quartzo e feldspato no mesossoma. Apresenta pleocroísmo variando de marrom escuro a amarelo claro, com granulação muito fina a fina $(\sim 0,01$ a $0,5 \mathrm{~mm})$, com inclusões de zircão e titanita e ocorre nas bordas e fraturas da granada indicando sua substituição.

A allanita se apresenta muito alterada e quase sempre associada à titanita. É encontrada na matriz do mesossoma, possui cor marrom escuro, com granulação fina $(\sim 0,25)$ e zoneamento bem definido em alguns grãos. Os grãos variam entre xenoblásticos a subidioblásticos, às vezes levemente orientados segundo a foliação principal. Inclusões de epidoto, monazita, rutilo, titanita e zircão são comuns (Fig. 13).

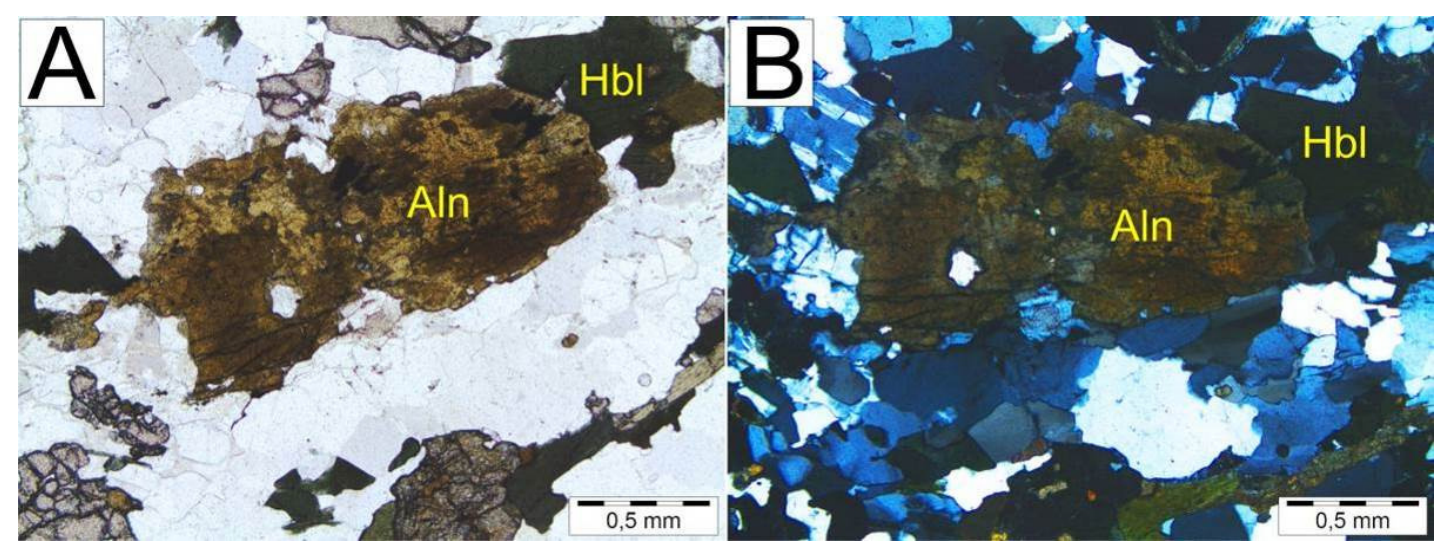

Fig. 13 - Fotomicrografia da lâmina ALFE24b, com cristal grande de allanita com bordas irregulares, zoneamento e orientada segundo a foliação principal. Polarizadores paralelos em A e cruzados em B..

Os grãos de quartzo e feldspatos são mais abundantes no leucossoma, chegando a $70 \%$, já no mesossoma ocupa cerca de 50\%. Apresentam granulação heterogênea variando de muito fina a muito grossa $(\sim 0,01 \mathrm{~mm}$ a $3,0 \mathrm{~cm})$, com textura granoblástica no meso e no leucossoma e porfiroclástica no mesossoma (grãos de até 4,0 cm). Os porfiroclastos de feldspatos formam sigmóides orientados segundo a foliação principal com bordas recristalizadas. O quartzo apresenta extinção ondulante, com grãos xenoblásticos, com contatos lobados a interdigitados. É muito comum feições de fusão como feldspatos e quartzo intersticiais ou formando filmes entre os grãos maiores, cristais que aparentam "boiar" em líquido de plagioclásio cristalizado, quartzo formando string beads entre grãos de feldspato (Fig. 14). 

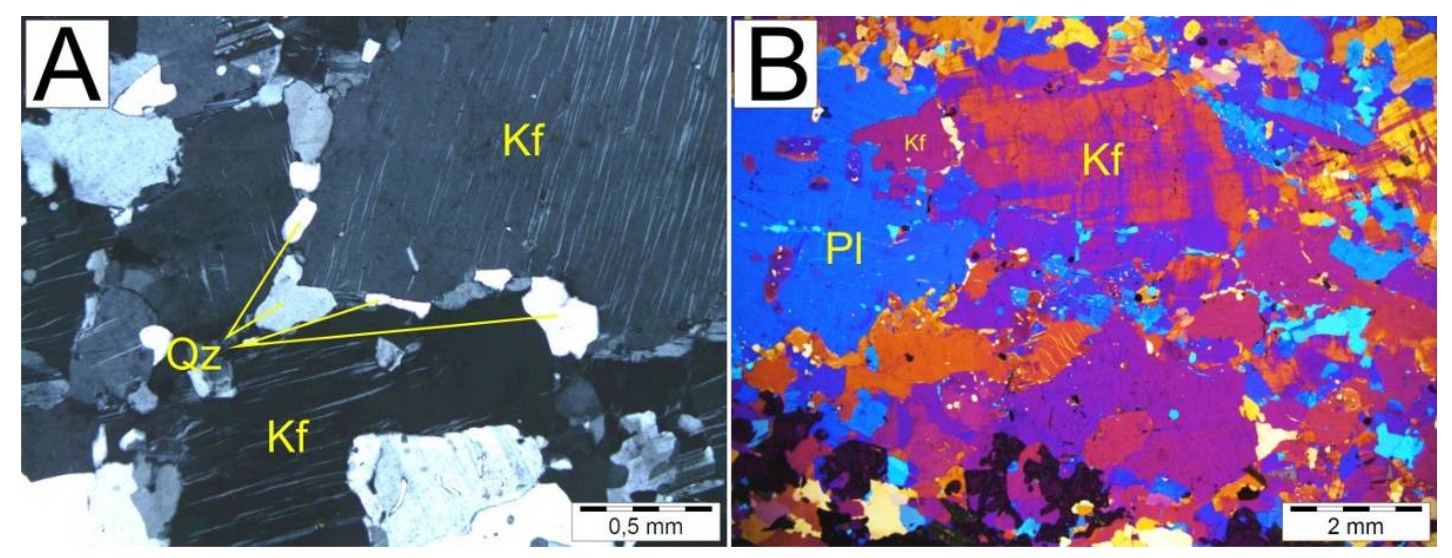

Fig. 14 - Fotomicrografias da lâmina ALFE24b com polarizadores cruzados em A e em B com acessório acoplado. Texturas de fusão. Em A quartzo formando string beads; em B cristal de feldspato potássico com bordas carcomidas e envolto por plagioclásio, como se estivesse desintegrando.

No leucossoma é comum a presença de porções alteradas e feldspatos substituídos por carbonato. Os minerais acessórios presentes estão dispersos no mesossoma ou inclusos em outros minerais, são arredondados ou euedrais, de granulação muito fina a média $(\sim 0,001-0,1)$. A titanita apresenta maior destaque pelo seu tamanho $(\sim 2,0 \mathrm{~mm}) \mathrm{e}$ quantidade (5\%), mas também, são encontrados zircão, rutilo e apatita em menor escala.

No quadro a seguir é representada a relação de cristalização e blastese da rocha.

\begin{tabular}{|l|c|c|c|}
\hline \multicolumn{1}{|c|}{ Minerais } & Pré-deformação & Sin-deformação & Pós-deformação \\
\hline Granada & & & \\
\hline Biotita & & & \\
\hline Hornblenda & & & \\
\hline Feldspatos & & & \\
\hline
\end{tabular}

\subsubsection{Rochas ultramáficas}

As rochas ultramáficas estão expostas na forma de blocos de rocha muito alterada, de cor cinza escuro a ocre amarronzado. A disposição dos blocos no campo, indica que as rochas ultramáficas formam corpos lenticulares de pequenas dimensões. Nos blocos observam-se bordas com leve orientação e núcleos maciços. A rocha apresenta granulação fina $(\sim 0,01 \mathrm{~mm})$, textura blastocumulática a maciça e serpentinítica. É composta por serpentina $(\sim 10 \%)$, clorita $(\sim 20 \%)$, clinopiroxênio $(\sim 5 \%)$, tremolita $(\sim 15 \%)$, olivina $(\sim 30 \%)$, opacos $(<5 \%)$, carbonato $(<5 \%)$. 
Ao microscópio a serpentina tem cor amarelada e apresenta-se substituindo a olivina e outros minerais gerando textura mesh. A olivina é incolor, xenoblástica, com granulação fina ( 0,01 a $2 \mathrm{~mm}$ ), muito fraturada, com bordas irregulares, as quais foram geradas pela substituição de serpentina. A tremolita é incolor e de hábito ripiforme, subidioblástica gerando textura decussada e granulação fina $(\sim 0,01-1,0 \mathrm{~mm})$. A hornblenda magnesiana é incolor, com granulação fina $(<0,5 \mathrm{~mm})$, xenoblástica, muito alterada, e encontra-se substituída por serpentina, clorita e tremolita em alguns grão. O carbonato é subidioblástico, varia de 0,01 a 1,0 mm, geralmente alterando a serpentina e clorita. Os minerais opacos são xenoblásticos com granulação muito fina $(\sim 0,001$ a 0,5 mm) (Fig. 15).
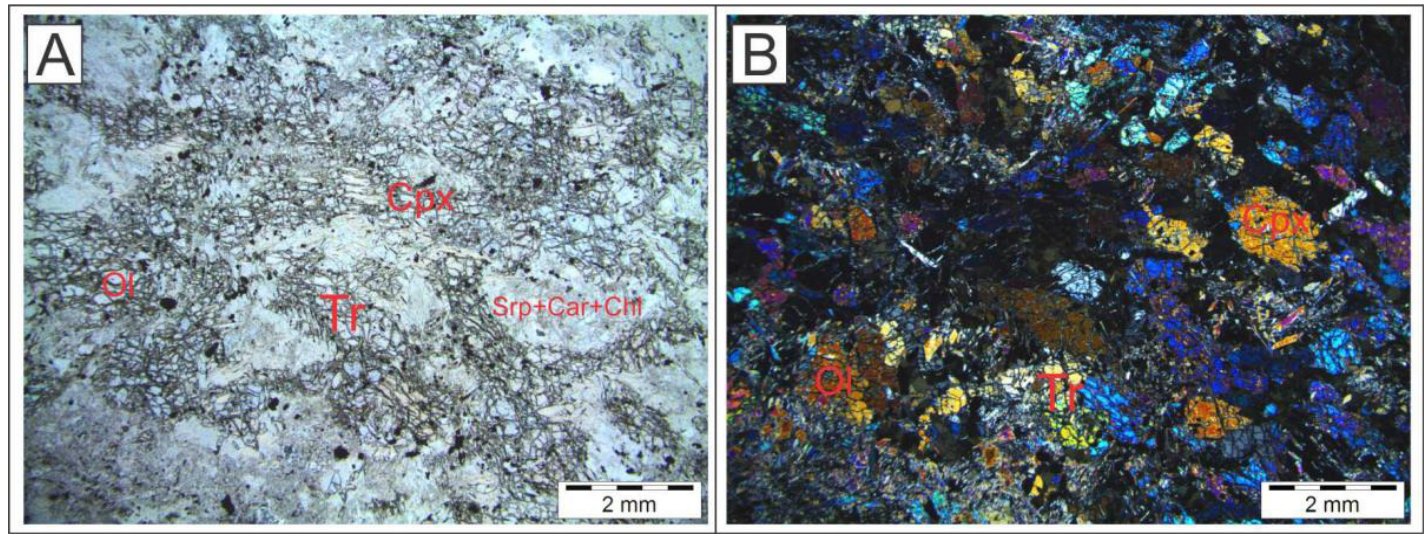

Fig. 15 - Fotomicrografia da lâmina ALFE48 com polarizadores paralelos em A e cruzados em B. Rocha ultramáfica com textura blastocumulática a maciça e serpentinítica. Aglomerados de serpentina, clorita e carbonato são frequentes.

\subsubsection{Geologia Estrutural do Compexo Campos Gerais}

Todo o conjunto reúne rochas que estão associadas ao craton do São Francisco e que foram envolvidas no metamorfismo e deformação do Orógeno Brasília (Brito Neves et al., 1999). Apresentam bandamento composicional e migmatítico que define a foliação principal $\mathrm{S}_{2}$, sendo a biotita, o quartzo, o feldspato e as vezes a fornblenda, os minerais que marcam essa foliação principal $\left(S_{2}\right)$. Devido a deformação na região, muitas estruturas são reconhecidas tais como boudins de camadas ricas em biotita ou de leucossoma e dobras intrafoliais com eixo contido na foliação $S_{2}$. $N a$ zona de cisalhamento alguns porfiroclastos de feldspato potássico maiores que $5 \mathrm{~cm}$ indicam a movimentação normal no sentido sinistral com topo para SE como observado 
anteriormente. Não existe muita diferença da orientação da foliação entre as unidades, sendo a atitude média da foliação para o Complexo Campos-Gerais de N74W/54SW como observado no esterograma a seguir (Fig. 16).

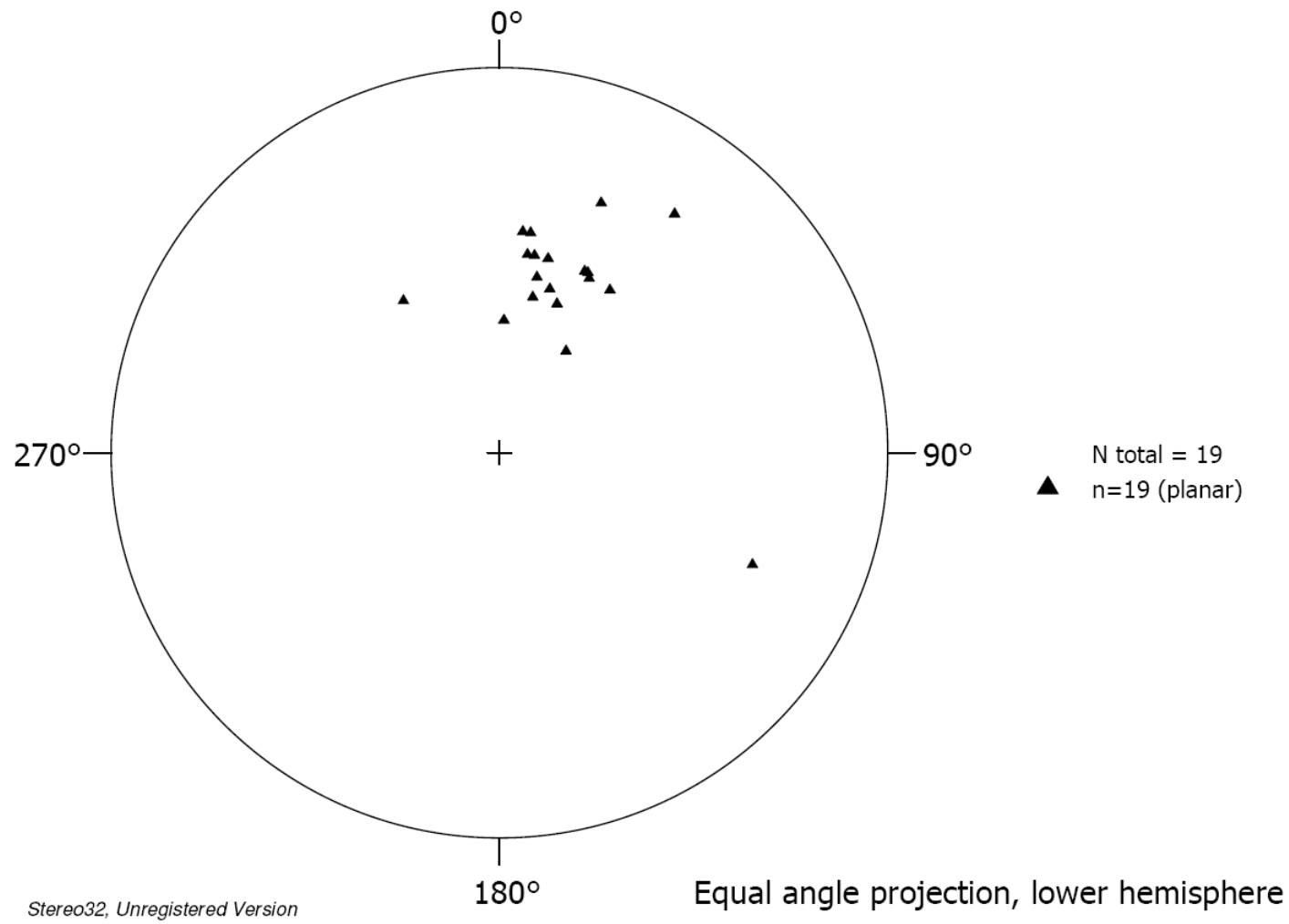

Fig. 16 - Projeção estereográfica da foliação $S_{2}$ do Complexo Campos Gerais. A foliação é plotada como polos e representada por triângulos pretos. Direção preferencial N74W/54SW.

\subsection{Unidade da Nappe Três Pontas-Varginha}

Os granulitos da Nappe Três Pontas-Varginha são migmatitos do tipo estromático com bandamento metamórfico composicional, com diferentes espessuras $(0,1 \mathrm{~mm}$ a 3,0 $\mathrm{cm})$ de leuco, meso e melanossoma. Apresenta boa exposição na área, com afloramentos de blocos frescos, matacões e lajedos até minas de saibro, em que a rocha se apresenta muito alterada. A cor varia entre cinza escuro a branco, com porções rosadas, quando alterada varia de porções brancas dominadas por caolim, a marrom. A granulação é heterogênea variando entre as camadas, com granulação maior nas bandas leucocráticas (até 3,0 mm) e com porfiroblastos de granada de até $1,0 \mathrm{~cm}$ em todas as bandas. $\mathrm{O}$ 
contato entre as bandas é abrupto em algumas porções, com possível formação de selvedge de biotita ao redor do leucossoma. Localmente o contato é transicional entre as bandas. A rocha é foliada, com leve crenulação e apresenta textura granoblástica gerada pelo arranjo dos grãos de quartzo e feldspatos, porfiroblástica gerada pela granada, a lepidogranoblástica, nas bandas mais ricas em biotita. Muitos dos cristais de cianita presentes não apresentam orientação preferencial, podendo formar bolsões de forma sigmoidal, envoltos pela foliação (Fig. 17).

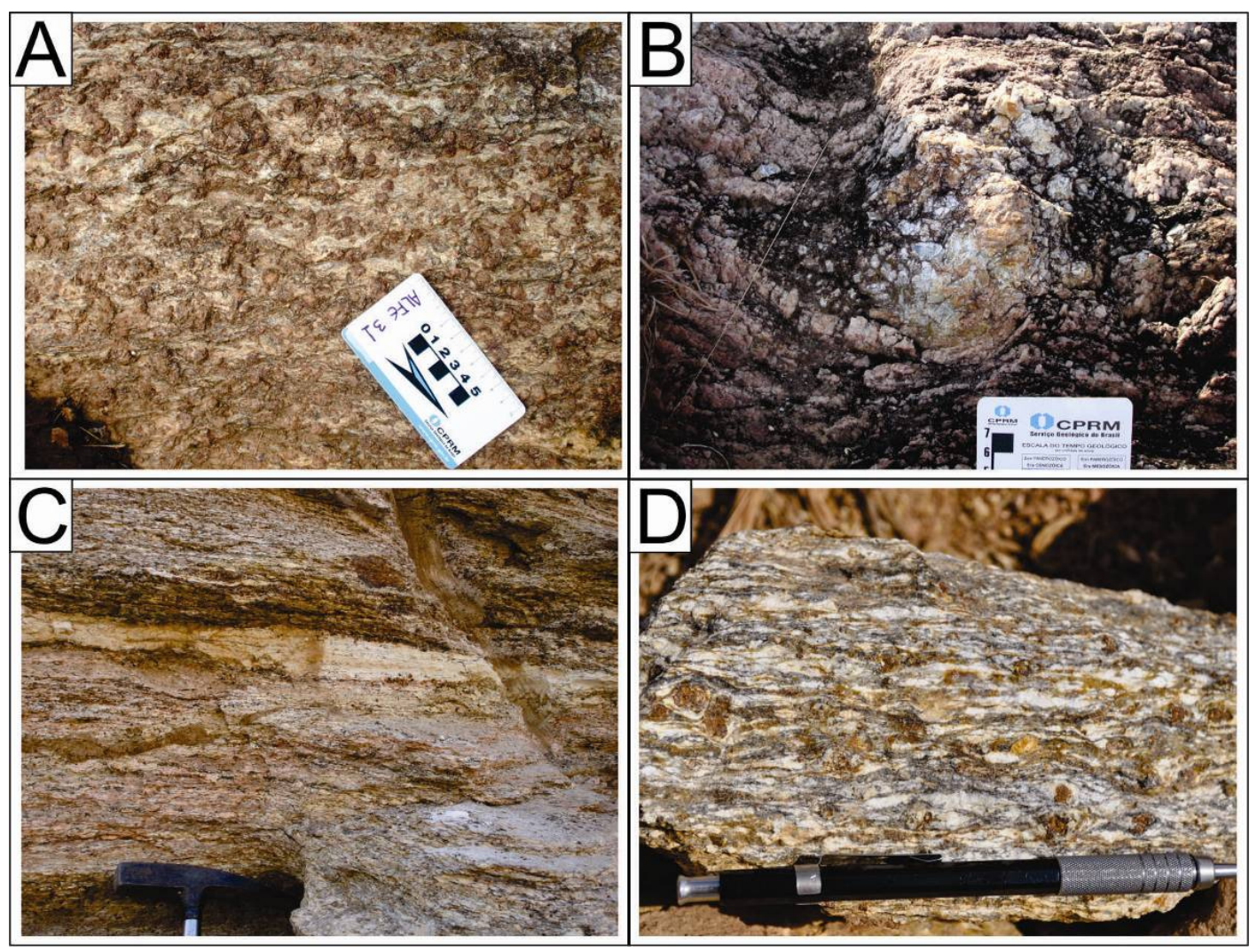

Fig. 17 - Foto dos afloramentos ALFE31 em A, ALfe53 em B, ALFE59 em C e ALFE52 em D. Em A, bandamento da rocha não é muito definido, sendo difícil distinguir as camadas; B, bolsão de cianita com formato sigmoidal com bandamento amoldado ao redor; C, bandamento composicional bem definido com formação de selvedge de biotita no leucossoma e em D, bandamento composicional com detalhe para granadas rotacionadas formando sombra de pressão quartzo-feldspáticas.

A rocha é composta por quartzo ( 20-40\%), ortoclásio ( 20-30\%), plagioclásio $\mathrm{An}_{25}$, oligoclásio $(\sim 10 \%)$, granada ( 15-25\%), biotita ( 10-20\%), cianita $(\sim 5-10 \%)$, minerais opacos $(\sim 5 \%)$ e minerais acessórios, como zircão e rutilo. Minerais retrometamórficos como clorita e muscovita são comuns. 
A rocha apresenta muitas estruturas e texturas metamórficas e de cristalização de fundido, principalmente no leucossoma, estas compostas por quartzo e feldspato, tais como aglomerados de microgrãos intersticiais, textura gráfica, em que o líquido fundido percola entre os poros englobando outros grãos, formando grãos maiores com bordas recristalizadas, apresenta fundido aprisionado que cristaliza na forma de fitas (flaser ) ou microgrãos intersticiais (string beads), apresenta lentes de quartzo orientado segundo a foliação principal. O feldspato potássico apresenta lamelas de exsolução formando pertita e mesopertita, e tem as bordas substituídas por mirmequita quando em contato com plagioclásio. O quartzo e feldspato estão presentes em todas as bandas e apresentam granulação variando de fina a média $(0,1-2,0 \mathrm{~mm})$ e geram textura granoblástica com formas e contatos variados (Fig. 18).

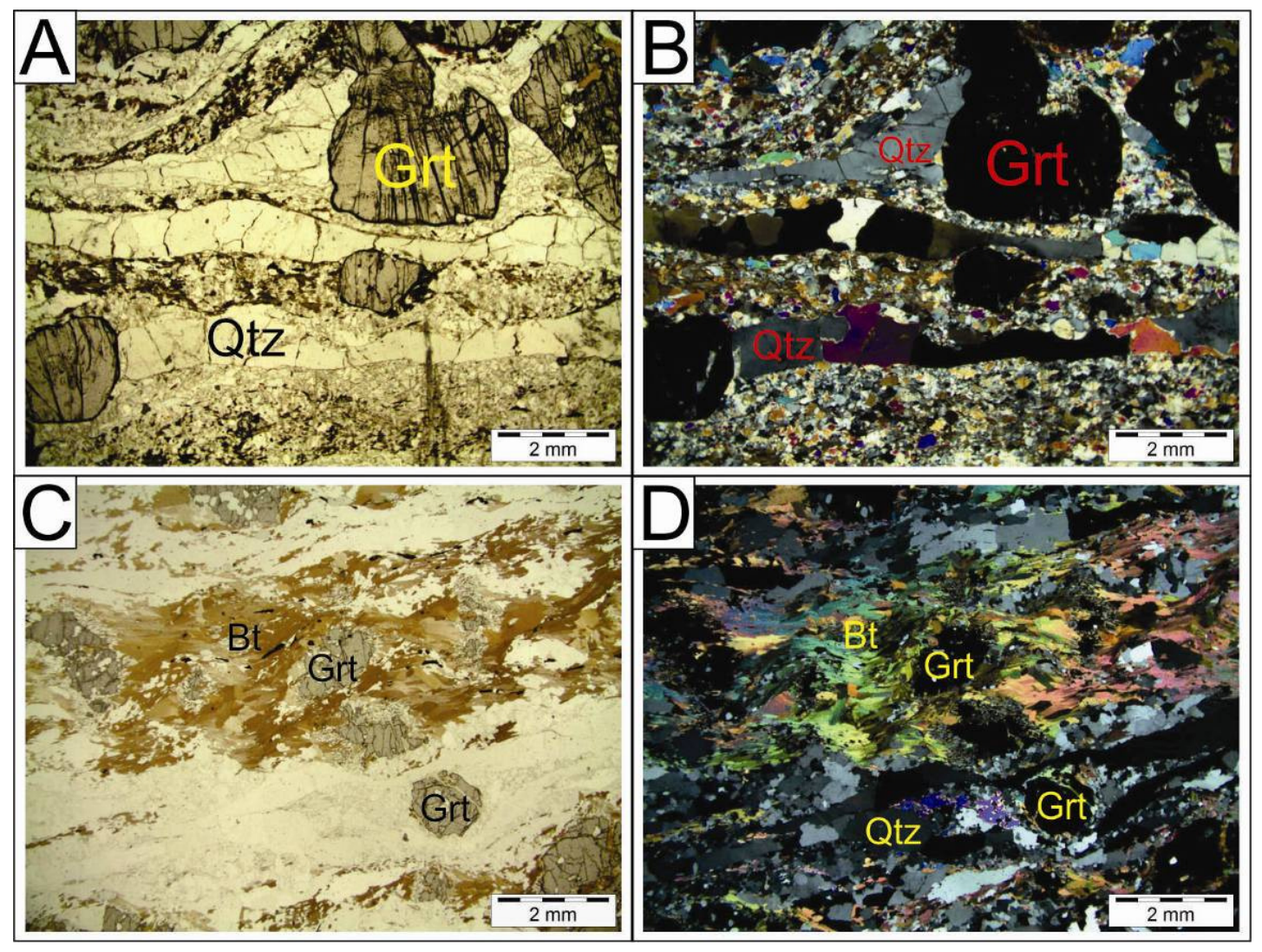

Fig. 18 - Fotomicrografias da lâmina ALFE31. Polarizador paralelo a esquerda e cruzado a direita. Em A e B, bandamento composicional da rocha com leucossoma na forma de fitas de quartzo flaser, granada rotacionada com sombra de pressão quartzo-feldspática; em C e D, banda mais máfica com biotita substituindo a granada, mas também compondo a foliação principal. No leucossoma a granada apresenta-se euédrica. A rocha apresenta uma leve crenulação. 
A granada é porfiroblástica, de cor rosa, com granulação grossa $(\sim 0,5 \mathrm{~mm}-2,0 \mathrm{~cm})$, podendo ser xeno a subidioblástica, sigmoidal, com bordas irregulares a arredondadas e contatos suaves ou interdigitados, com sombra de pressão de quartzo e com foliação se amoldando ao seu redor. Apresenta inclusões de cianita, quartzo e feldspatos arredondados, rutilo e biotita. Pode apresentar fraturas que foram preenchidas por biotita e plagioclásio (Fig. 19).

A biotita é pleocróica, marrom a amarelo claro, orientada segundo a foliação principal e com granulação muito fina $(\sim 0,001-0,2 \mathrm{~mm})$. A substituição por clorita verde retrometamórfica é comum. Apresenta inclusões de minerais acessórios que geram halos pleocróicos e ocorre na forma de simplectitos nas bordas da granada. A muscovita aparenta ser tardia em algumas porções, pois se ocorre sem orientação nas amostras, mas quando está disposta segundo a foliação principal, substituiu a biotita.

A cianita ocorre em bolsões e aglomerados ou compondo a matriz da rocha, porém é muito rara em seções delgadas, e quando observada é incolor, de granulação fina a grossa, pode se apresentar orientada segundo a foliação principal, ou dispersas na matriz e também ocorre como inclusão em granada (Fig. 19).

Os minerais opacos apresentam no máximo $2 \mathrm{~mm}$, podendo estar orientados segundo a foliação principal, ou ocorrer como inclusões xenoblásticas em granada e biotita. Os acessórios podem ser subidioblástico a xenoblástico, às vezes prismáticos dispersos na matriz. 


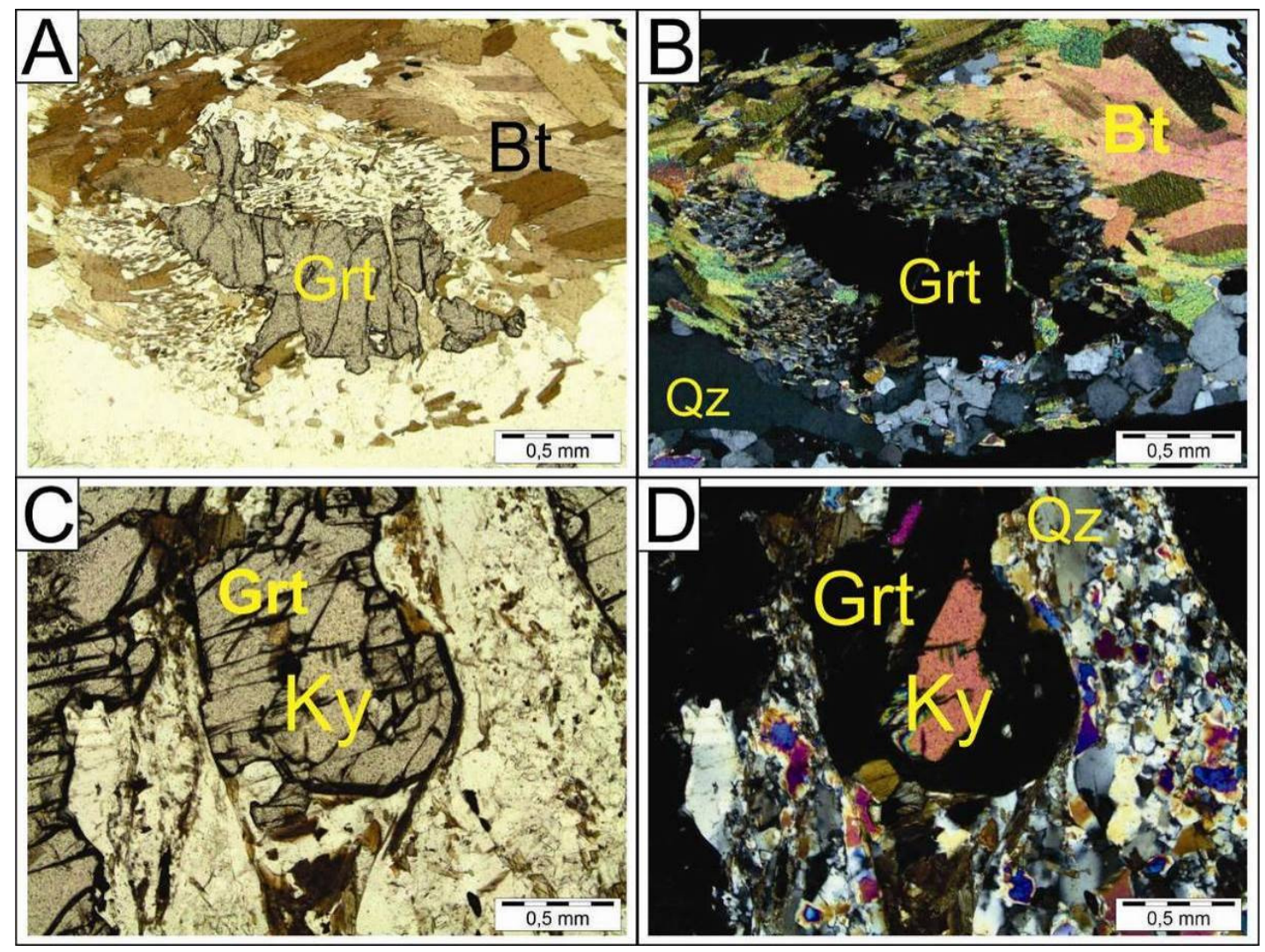

Fig. 19 - Em A e B, fotomicrografia da lâmina ALFE31, com simplectito de biotita e feldspato quando em contato com granada (polarizadores paralelos em A e cruzados em B); em C e D, fotomicrografia de granada com inclusão de cianita, indicando que a granada passou pelo campo da cianita durante sua formação. (polarizadores paralelos em C e cruzados em D).

\subsubsection{Geologia Estrutural da Unidade da Nappe Três Pontas-Varginha}

As rochas da Nappe Três Pontas-Varginha são consideradas como sedimentos de anti-arco, que sofreram subducção, atingindo altas pressões, seguida de rápida exumação (Garcia, 2001 e Campos Neto et al., 2004). A nappe é composta por rochas de fácies granulito de alta pressão, classificados como granulitos aluminosos migmatíticos, com algum bandamento composicional preservado e realçado pela fusão e metamorfismo, com bandas de leucossoma com feldspatos e quartzo bem deformados e melanossoma com cianita e granada, esta última rotacionada. O bandamento é orientado segundo a foliação principal $S_{2}$. A rocha se apresenta muito alterada na área de estudo, dificultando a identificação de estruturas e mineralogia. Sendo a atitude média da foliação para as rochas da Unidade da Nappe Três Pontas-Varginha, de N80W/44SW, representada pelo estereograma a seguir (Fig. 20). 


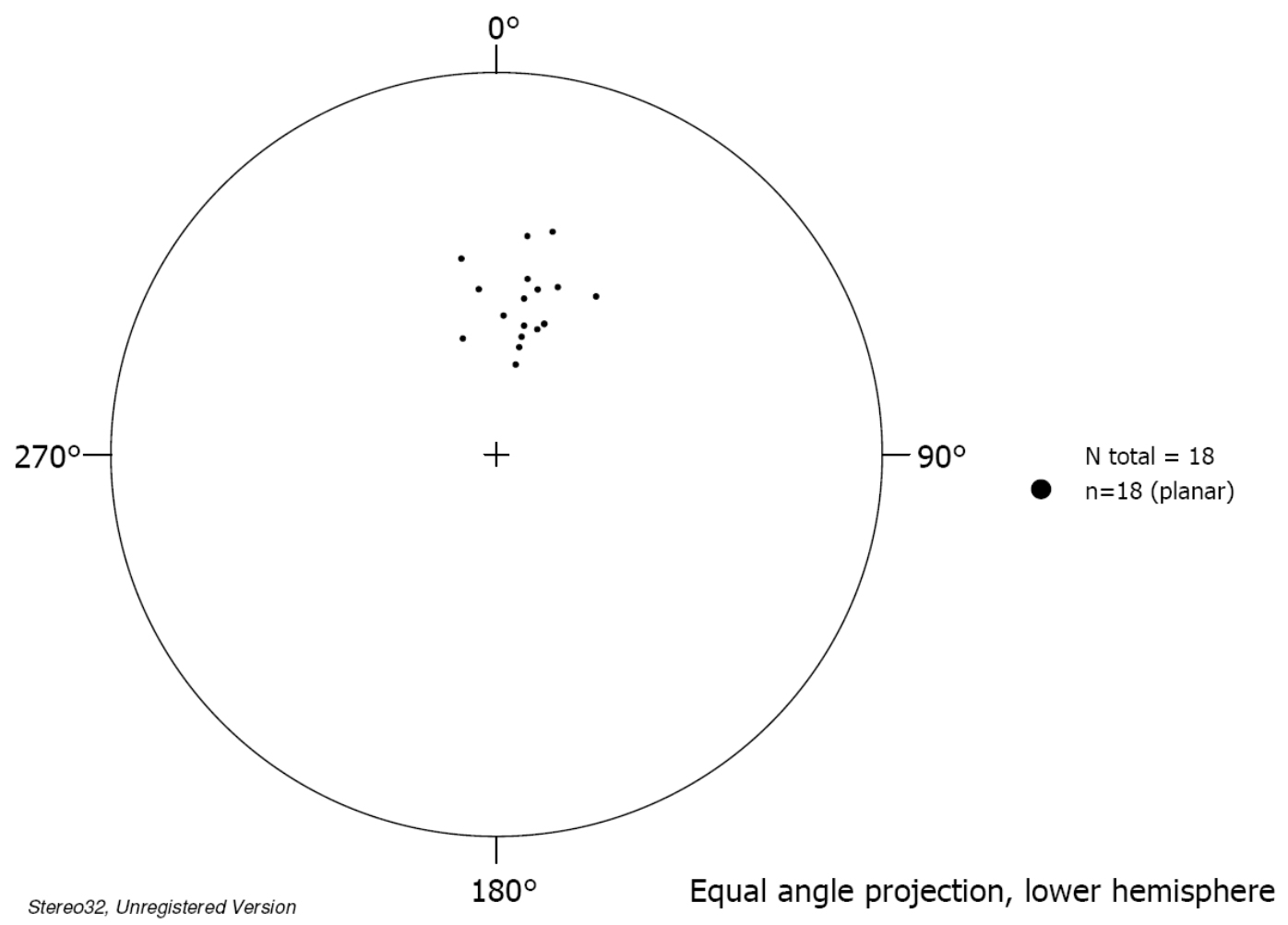

Fig. 20 - Projeção estereográfica da foliação $S_{2}$ da Unidade da Nappe Três Pontas-Varginha. A foliação é plotada como polo e representada por pontos pretos. Direção preferencial N80W/44SW.

\subsection{Rochas da Nappe Socorro-Guaxupé}

As rochas da Nappe Socorro-Guaxupé estão dispostas na porção sul da área de estudo e podem ser divididas em duas unidades: a Unidade Granulítica Basal e a Unidade Diatexítica Intermediária. Dentro das unidades há vários tipos de rochas, entre eles granulitos, máfico e félsico, charnockito, anfibolito, e migmatito. O que diferencia a unidade intermediária da basal é a porcentagem de fusão da rocha, quanto mais ao sul, maior a porcentagem, que é controlada pela composição mais fértil do protolito.

Na Unidade Granulítica Basal há intercalação, desde escala centimétrica, até métrica, de granulitos máficos e félsicos, e na Unidade Diatexítica Intermediária predomina diatexitos com lentes de granulito máfico e félsico subordinados. 


\subsubsection{Unidade Granulítica Basal}

As rochas da Unidade Granulítica Basal apresentam cor cinza escuro esverdeada a rosa amarronzada, com exposição na forma de lajedos, blocos, pedreiras e cortes de estrada, com variados níveis de alteração intempéricas. A rocha quando muito alterada é facilmente confundida com a unidade diatexítica, pois, adquire aspecto granítico. Apresenta granulação muito variada, desde fina a muito grossa $(0,1 \mathrm{~mm}$ a $5,0 \mathrm{~cm}) . \mathrm{O}$ litotipo predominante é dado por intercalação de granulito máfico e félsico, ambos migmatíticos. O bandamento é irregular, com contatos transicionais a abruptos e as camadas variam de espessura em escala milimétrica a métrica $(0,1 \mathrm{~mm}$ a $\sim 1,0 \mathrm{~m})$. Há predomínio de granulito félsico sobre o máfico, que formam lentes paralelas a subparalelas à foliação, que também são paralelas a lentes e veios de leucossoma granítico ou charnockítico. O leucossoma pode cortar a foliação principal ou ainda formar bolsões e lentes de mais de $1 \mathrm{~m}$ de espessura, nesse caso também paralela ao bandamento composicional.

Muitas estruturas deformacionais, tais como dobras intrafoliais, restos de charneiras espessadas com flancos adelgaçados e rompidos, boudins e bandamento composicional, ainda são parcialmente preservadas, mesmo depois do processo de migmatização. O bandamento composicional pode ser cortado por veios e bolsões de leucossoma granítico e charnockítico, que chegam a conter pedaços de granulitos com estruturas preservadas, às vezes formando selvedge de biotita nas bordas dos granulitos.

No leucossoma granítico ocorrem megacristais de hornblenda, biotita e granada, muitas vezes com núcleos de piroxênio nos dois primeiros. Nos veios de charnockito, por sua vez, ocorrem megacristais de ortopiroxênio e granada. No granulito máfico é comum concentração de hornblenda, biotita e granada na forma de bolsões, dando origem a granada granulito máfico ou granada anfibolito (Fig. 21). 


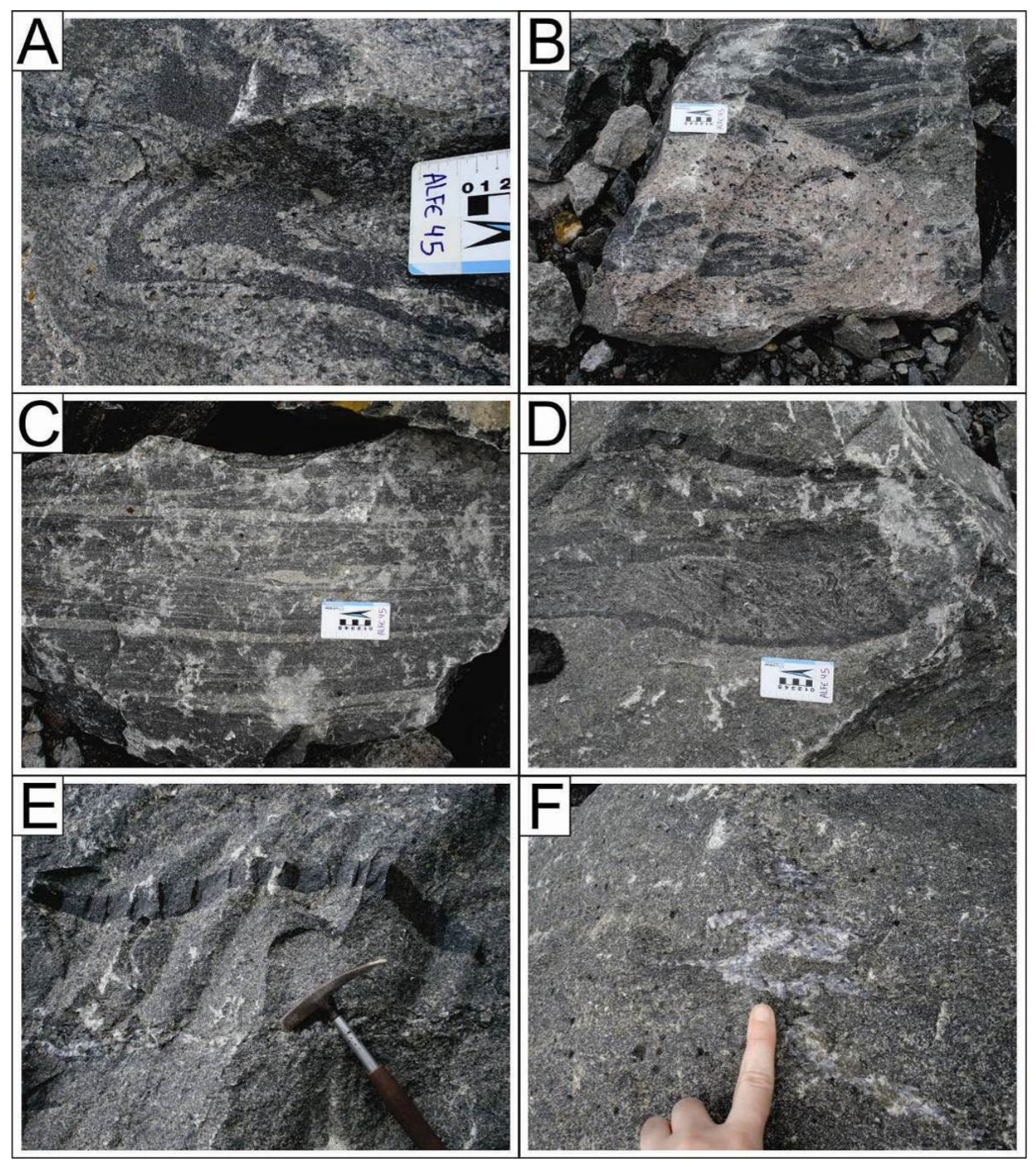

Fig. 21 - Fotos do afloramento ALFE45, Pedreira Santa Terezinha, representando a Unidade Granulítica Basal. Em A, bandamento composicional com dobras intrafoliais; em B, três diferentes rochas em um só bloco, indicando a variedade na unidade, com presença de bandamento migmatítico estromático sendo cortados por leucossoma granítico com rafts de granulito; em C, bandamento migmatítico estromático regular; em D, xenólito da rocha original, com foliação e bandamento preservados, apresentando selvedge de hornblenda; em E, lente de granulito máfico em granulito félsico concordante com a foliação; e em F, charnockito de coloração azulada, cortando o granulito félsico. 


\subsubsection{Hornblenda granulito félsico e hornblenda granulito máfico}

O hornblenda granulito félsico ocorre intercalado com o granulito máfico e seus contatos são gradacionais (Fig. 22), sendo ambos, foliados. As texturas variam entre granoblástica, porfiroblástica a lepidonematoblástica. O hornblenda granulito félsico apresenta granulação média (1,0-3,0 mm) e é composto por quartzo ( 20-30\%), feldspato potássico (ortoclásio) ( 5-10\%), plagioclásio, $\mathrm{An}_{26}$, oligoclásio, ( 15-20\%), ortopiroxênio ( 5-10\%), hornblenda ( 5-20\%), biotita ( 5-15\%), minerais opacos ( 5\%), e apatita e zircão como minerais acessórios $(<3 \%)$. O hornblenda granulito máfico apresenta granulação fina-média $(0,5-3,0 \mathrm{~mm})$ e é composto por quartzo ( 15-20\%), feldspato potássico (ortoclásio) ( $<5 \%$ ), plagioclásio, $\mathrm{An}_{30}$, andesina, ( 10-15\%), ortopiroxênio ( 15-25\%), clinopiroxênio (10-15\%), hornblenda ( 25 - 35\%), biotita $(\sim 10-15 \%)$, minerais opacos $(\sim 10 \%)$, e apatita e zircão como minerais acessórios $(<3 \%)$. Ambas as rochas apresentam como minerais tardios de alteração carbonato, cummingtonita, actinolita e mica branca (Fig. 23).

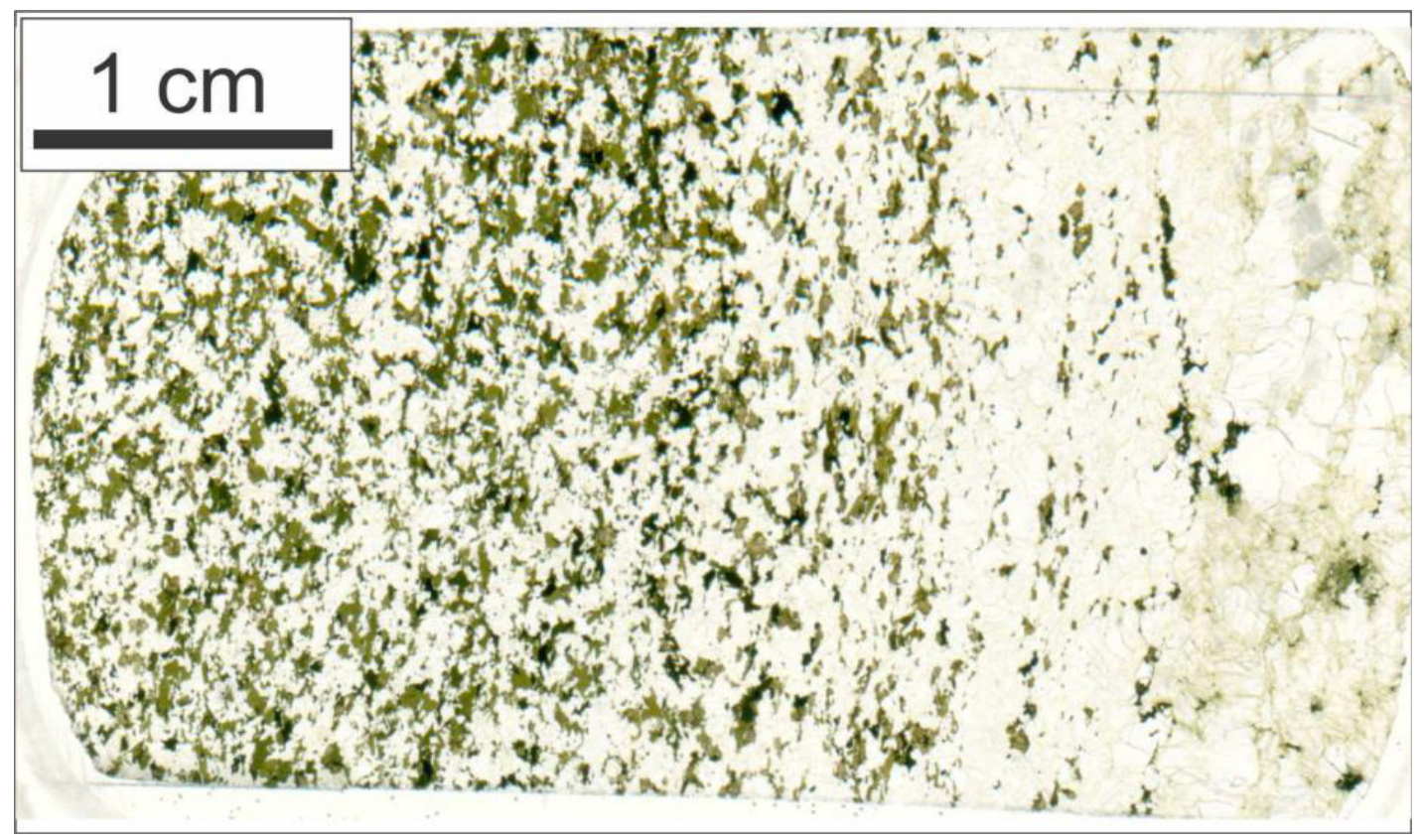

Fig. 22 - Lâmina digitalizada da amostra ALFE45Ia apresentando o contato gradacional entre hornblenda granulito máfico (porção da esquerda) e hornblenda granulito félsico (porção da direita). 


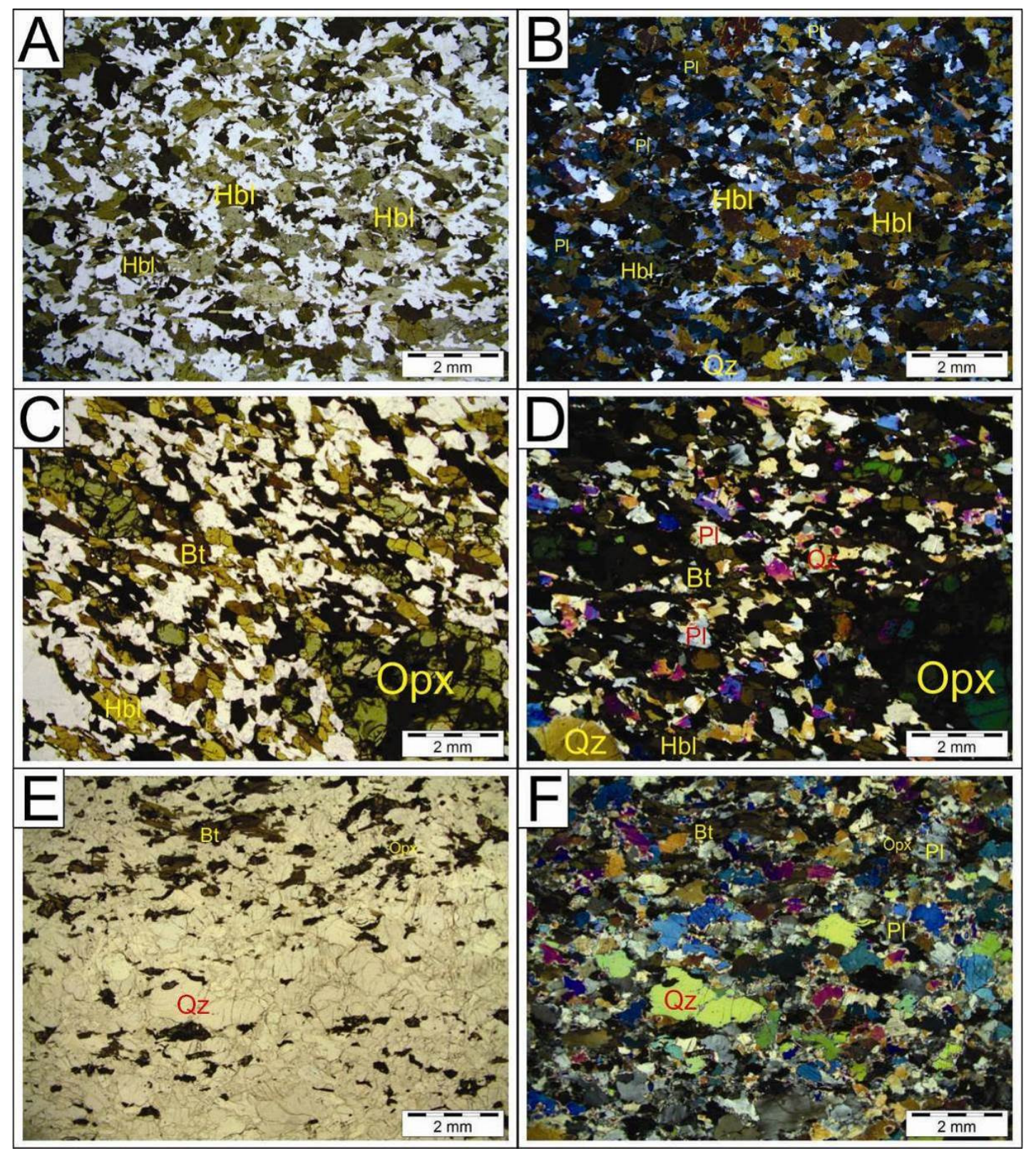

Fig. 23 - Fotomicrografias de hornblenda granulito félsico, com detalhe para foliação marcada pela hornblenda em A e B (amostra ALFE63c, polarizadores paralelos e cruxados respectivamente); Em C e D fotomicrografia do hornblenda granulito máfico com hornblenda, biotita e ortopiroxênio marcando a foliação principal (amostra ALFE45Ia, polarizadores // na primeira e X na segunda); em E e F contato gradual entre o hornblenda granulito máfico com o hornblenda granulito félsico, detalhe para foliação marcada pelo estiramento de quartzo e feldspato no granulito félsico (amostra ALFE45Mb, polarizadores paralelos a esquerda e cruzados a direita). 
A hornblenda apresenta formas e tamanhos variados, com pleocrismo variando de verde garrafa a verde pardo, podendo chegar a $5 \mathrm{~mm}$ ou mais, sendo a maioria dos grãos subidioblásticos a xenoblástico. Apresenta-se em maior quantidade no hornblenda granulito félsico que no máfico. Possui contatos retos com outros grãos de hornblenda e lobado a interdigitado com os outros minerais. Apresenta inclusões de biotita, minerais opacos, quartzo e feldspatos. Alguns grãos ocorrem textura simplectítica e no leucossoma pode apresentar-se porfiroblástica euedral, orientada segundo a foliação principal. Apresenta granulação grossa $(>1 \mathrm{~cm})$. Os simplectitos formados na hornblenda são pseudomorfos de piroxênios compostos por cummingtonita, iddingsita, actinolita e carbonato, indicando retrometamorfismo. Em algumas porções a hornblenda apresenta bordas com cristais de clinopiroxênio, indicando um processo progressivo, mas o contrário é mais comum e é muito comum a presença de epidoto associado à hornblenda, formando grânulos pequenos, levemente pleocróico.

A rocha apresenta orto e clinopiroxênio, o segundo, em maior abundancia no granulito máfico, mas é mais comum aparecer substituindo o ortopiroxênio no processo de retrometamorfismo. Apresentam granulometria fina a média $(0,01-2,0 \mathrm{~mm})$ e estão orientados segundo a foliação principal gerando textura nematoblástica. O ortopiroxênio apresenta pleocroismo variando de rosa a verde, encontra-se muito fraturado com bordas irregulares a alteradas, são subidioblástico a xenoblástico, com bordas irregulares com contatos lobados com o quartzo e feldspato e interdigitado com os outros minerais. Apresenta-se orientado segundo a foliação principal gerando textura nematoblástica e quando no leucossoma, forma porfiroblastos, de granulação muito grossa $(\sim 1 \mathrm{~cm})$, com formas subeuédricas orientadas. Pode apresentar-se substituído por hornblenda, clinopiroxênio e biotita, quando a rocha apresenta-se muito alterada, o ortopiroxênio aparece sendo substituído por agregado de minerais fibrosos (iddingsita - agregado de serpentina e clorita tingido de hidróxido de ferro deixando-os vermelho acobreado) ou por simplectitos de anfibólios mais cálcicos na borda e hornblenda nas extremidades (cummingtonita, antofilita). As vezes apresenta-se substituído por clinopiroxênio. Nesses casos os cristais apresentam bordas carcomidas e são irregulares. Pode formar também, simplectitos de quartzo e plagioclásio quando em contato com feldspato potássico. (Fig. 24). 


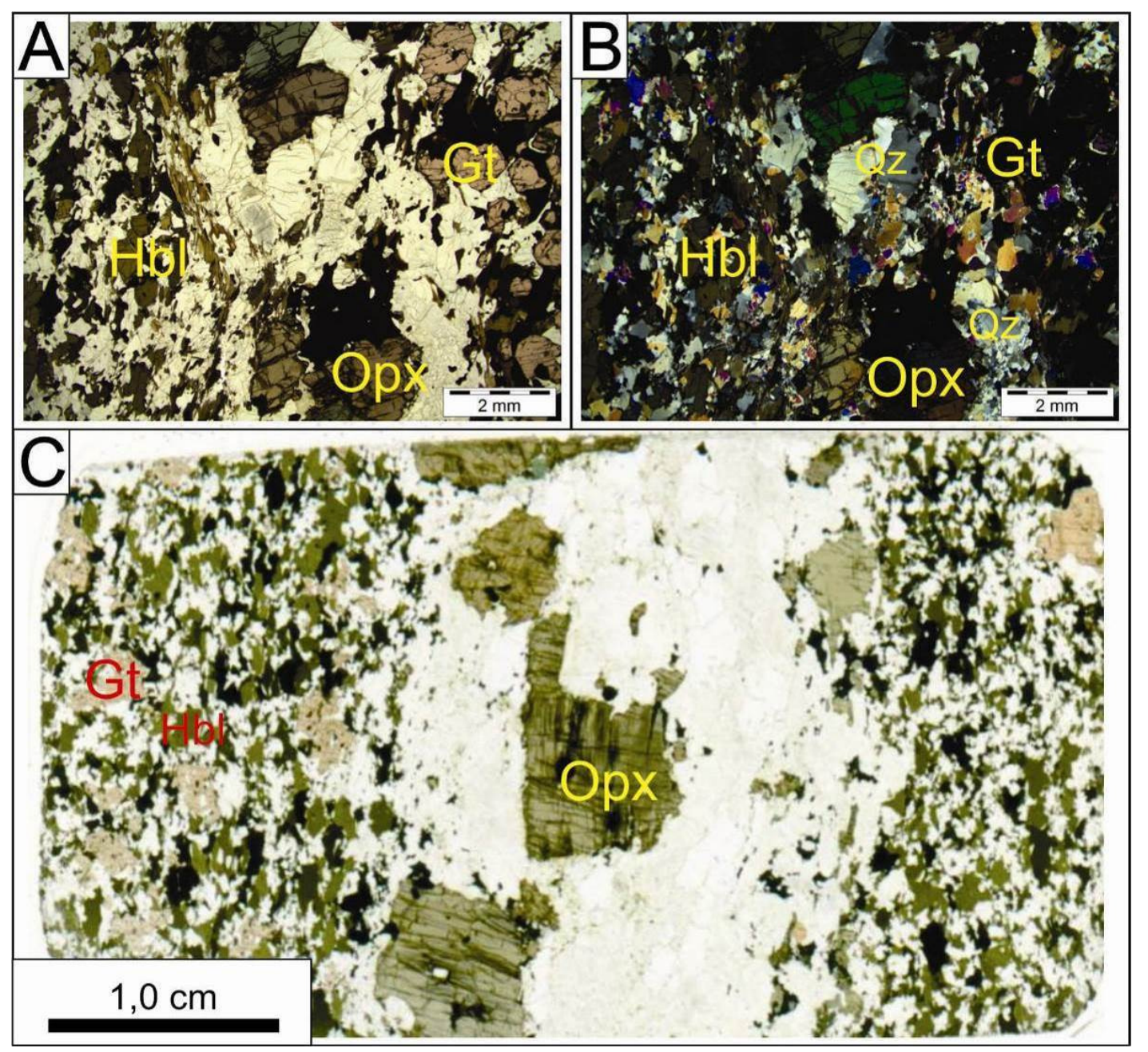

Fig. 24 - Em A e B, fotomicrografia de porfiroblastos de ortopiroxênio no leucossoma (lâmina ALFE45Ib), polarizadores paralelos e cruzados. Em C, lâmina digitalizada para microssonda, da amostra ALFE45V, apresentando leucossoma com porfiroblasto de ortopiroxênio, em contato com o granulito félsico e o granada granulito máfico;

O clinopiroxênio é subidioblástico, podendo chegar a $3 \mathrm{~mm}$, orientado segundo a foliação principal, é verde claro, podendo ser pleocróico variando de verde claro a amarelo esverdeado, apresenta-se substituído por hornblenda e biotita em suas bordas e fraturas. Apresenta inclusão de quarto e ortopiroxênio. (Fig. 25). 


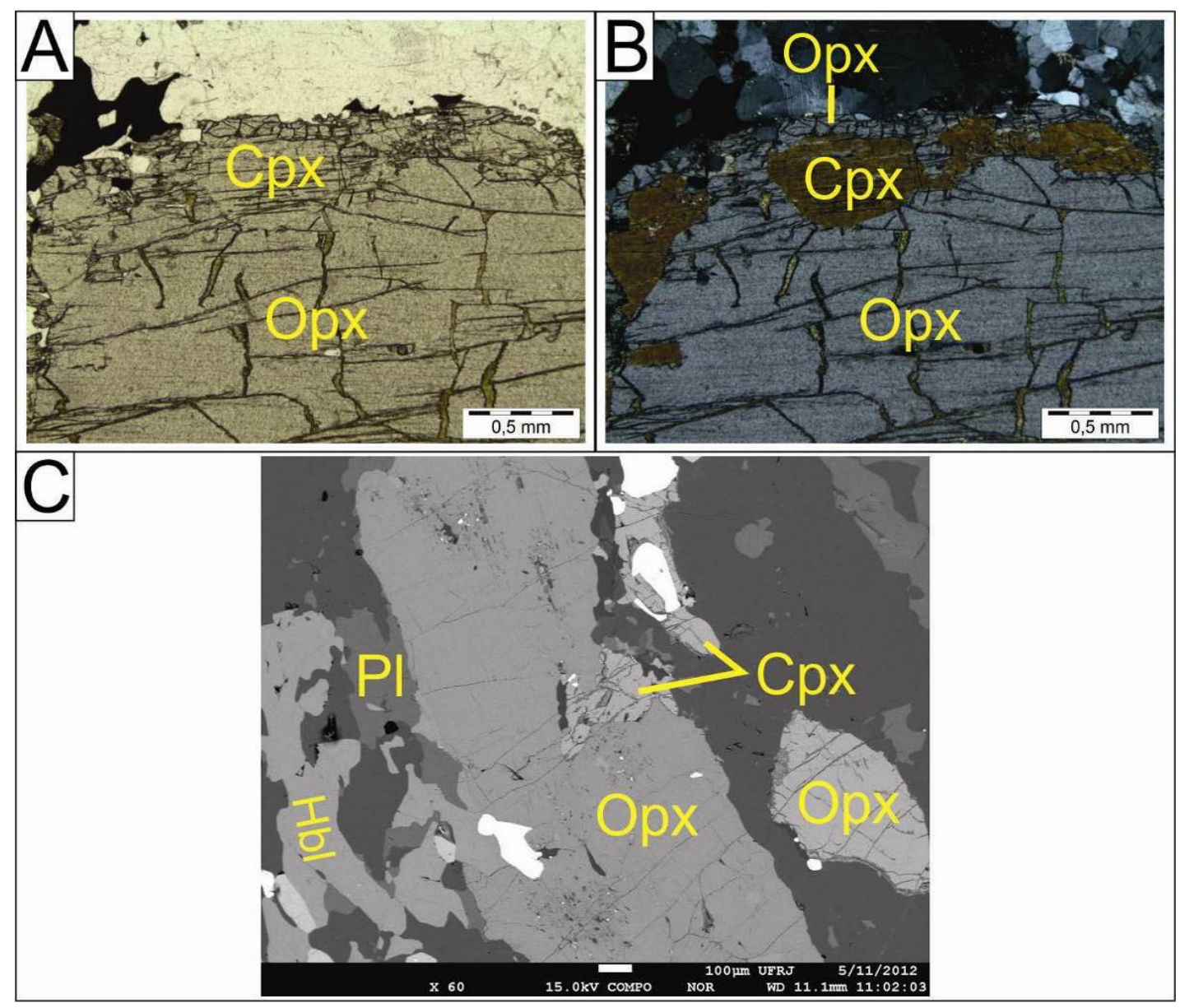

Fig. 25 - Em A e B fotomicrografia de ortopiroxênio com bordas recristalizadas por clinopiroxênio seguidos de uma segunda geração de ortopiroxênio (lâmina ALFE45V, polarizadores // e X respectivamente). Em $\mathrm{D}$, imagens feitas com microscópio eletrônico de varredura no Laboratório de microscopia eletrônica da UFRJ (lâmina ALFE45Ib), pôde ser observado as relações do clino e ortopiroxênio, onde o clinopiroxênio aparece substituindo o ortopiroxênio e opacos.

A biotita apresenta pleocroísmo variando de marrom escuro a bege claro, varia de 0,01 a $2 \mathrm{~mm}$, apresenta-se dispersa (sem orientação) ou substituindo a hornblenda, principalmente nas bordas. Apresenta inclusões de minerais opacos e hornblenda. Na maior parte da rocha a biotita é retrometamórfica e aparece em maior quantidade no granulito máfico.

Os grãos de quartzo e feldspatos estão presentes em toda a rocha, mas são mais abundantes no leucossoma onde se apresentam estirados e orientados segundo a foliação principal, observáveis macroscopicamente, com granulação média a grossa (0,5 a $5 \mathrm{~mm})$. No meso e melanossoma apresentam-se em menor quantidade e com menor 
granulometria e apesar de estarem orientados segundo a foliação principal, são mascarados pelos outros minerais.

Quartzo apresenta-se alongado segundo a foliação, com típica textura flaser, ou intersticial formando aglomerados de microgrãos entre os grãos maiores de feldspatos, que podem indicar equilíbrio por apresentar contatos poligonizados; são grãos xenoblásticos, variando de $0,01 \mathrm{~mm}$ a $1,0 \mathrm{~cm}$, apresentando inclusões de plagioclásio, seus contatos variam de reto a lobado entre si e lobado a interdigitado entre os outros minerais. Na porção máfica os grãos são menores, arredondados a xenoblásticos, com contato reto entre si e lobado com os outros minerais, gerando textura granoblástica.

O plagioclásio apresenta-se levemente alterado, varia de $0,001 \mathrm{~mm} \mathrm{a} 1 \mathrm{~cm}$, apresenta geminação polissintética na maioria dos grãos, varia de xeno a subidioblástico, com alguns grãos bem arredondados, contatos lobados entre si e irregular com os outros minerais, formando mirmequita quando em contato com o feldspato potássico.

O feldspato potássico se apresenta, na maioria dos casos, alterado (sericitização e carbonatação), com tamanhos variando de $0,001 \mathrm{~mm}$ a $1,0 \mathrm{~cm}$, é xeno- a subidioblástico, apresenta contato lobado entre si e irregular, serrilhado a interdigitado com os outros minerais e apresenta muitas lamelas de exsolução, gerando pertita e mesopertita. A quantidade de feldspato potássico diminui à medida que aumenta a quantidade de hornblenda na transição do máfico para o félsico.

O granulito félsico apresenta muitas evidências de fusão que são bem demonstradas nos grãos de quartzo e feldspatos, como aglomerados de microgrãos ou filmes intersticiais de quartzo e feldspatos que mimetizam o fundido aprisionado (Fig. 26).

Os minerais acessórios (zircão e apatita) variam de arredondados até euedrais, com hábito cúbico (quadrado) ou na forma de agulhas. 


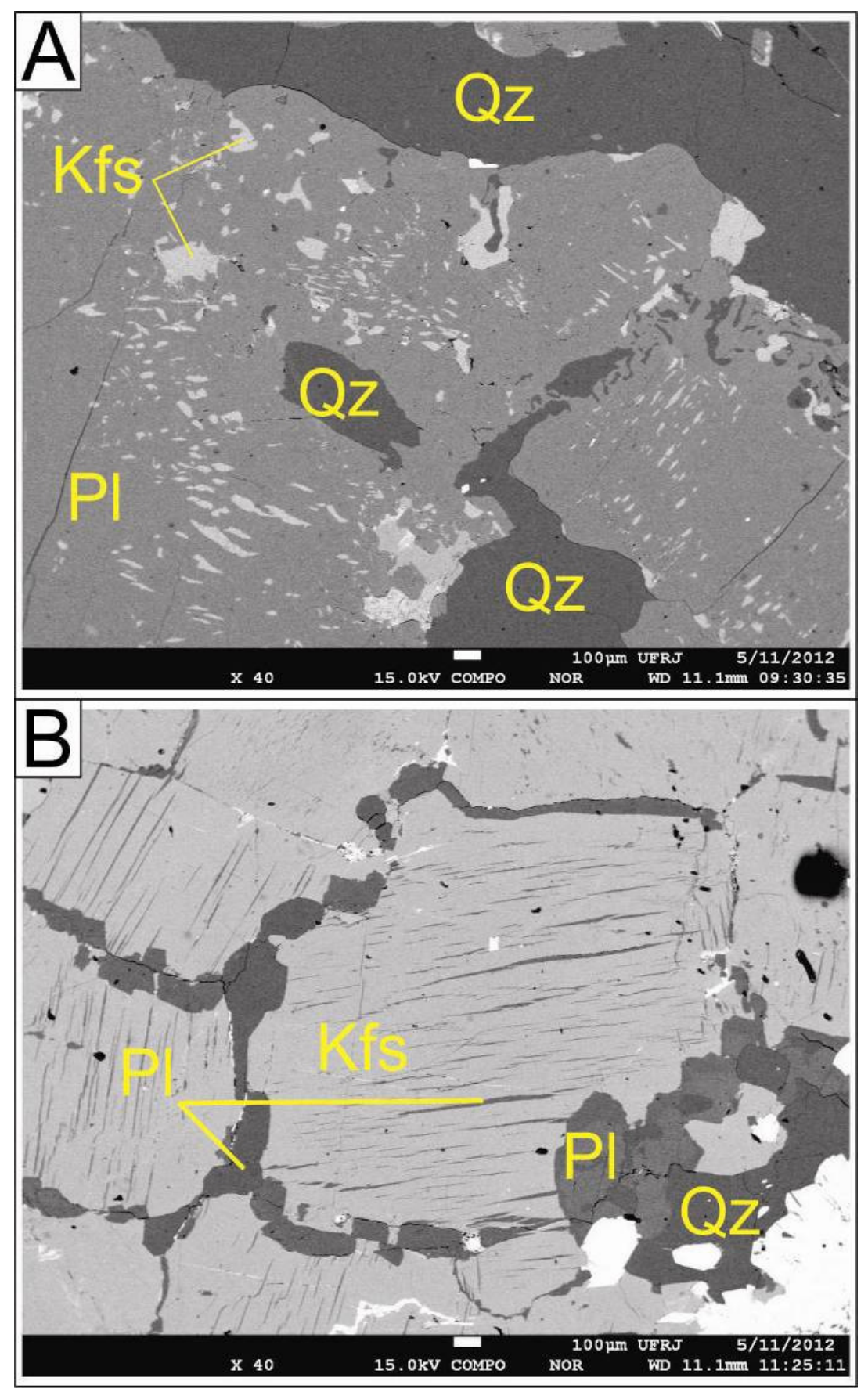

Fig. 26 - Imagens de texturas e estruturas de fusão em microscópio eletrônico de varredura. (LAB-SONDA, UFRJ). Em A e B, quartzo intersticial a grãos de feldspatos e quando em contato com o plagioclásio forma mirmequitas. O feldspato potássico apresenta muitas lamelas de exsolução de plagioclásio; Cristal de plagioclásio envolto por quartzo. Lâmina ALFE45Ib. 


\subsubsection{Granada granulito máfico}

O granada granulito máfico é rocha foliada de granulação média a grossa $(\sim 1,0-$ $3,0 \mathrm{~mm}$ ), de cor preta. O contato entre o granada granulito máfico e as outras rochas é abrupto, às veze com concentração de biotita entre eles, principalmente desenvolvida quando em contato com leucossoma, gerando o selvedge. É composto por granada ( $\sim 35-$ $50 \%$ ), biotita ( 15-20\%), plagioclásio, $\mathrm{An}_{23}$, oligoclásio ( 20-30\%), quartzo ( 5-10\%), feldspato potássico $(\sim 5-10 \%)$, ortopiroxênio ( 3-10\%), minerais opacos $(\sim 15 \%)$ e minerais acessórios, tais como apatita, zircão, espinélio. Sendo que o espinélio está incluso em opacos inclusos na granada. (Fig. 27).

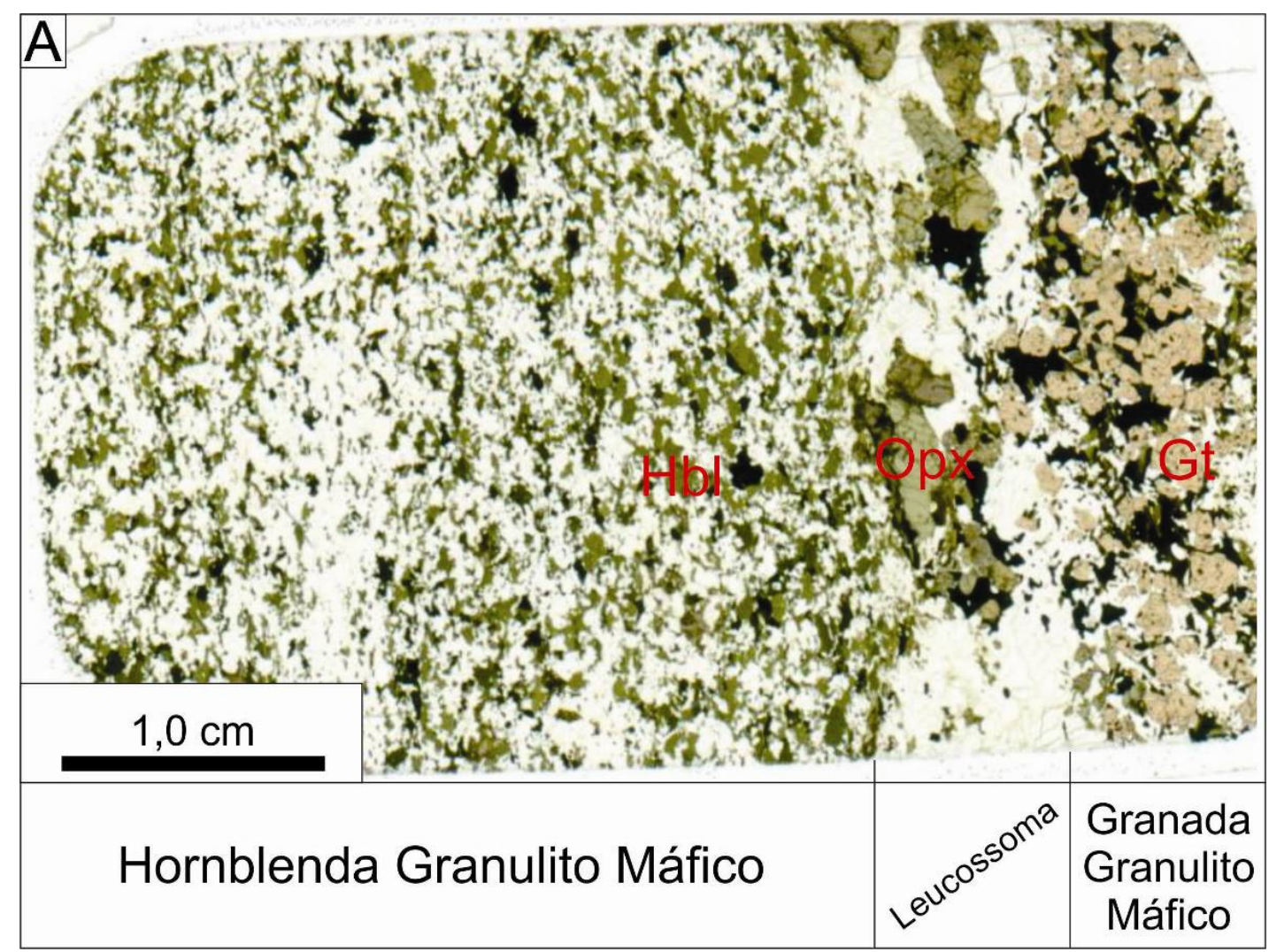

Fig. 27 - Lâmina digitalizada para microssonda. Contato do hornblenda granulito máfico com o granada granulito máfico, separados por pequena camada de leucossoma. Lâmina ALFE45Ib.

A granada é rosa, de granulação média a grossa $(\sim 1-5 \mathrm{~mm})$, apresenta-se subidioblástica, arredondada com bordas regulares, retas a lobadas. Apresenta inclusões de minerais opacos e biotita, as quais são arredondadas ou tabulares, quartzo e feldspatos. Às vezes forma aglomerados de grãos junto com biotita. 
O ortopiroxênio apresenta pleocroísmo variando de rosa a verde, com grãos xenoblásticos, com bordas irregulares, de contato lobado com o quartzo e feldspato e interdigitado com os outros minerais, pode estar entre grãos de granada, e sempre está associado aos minerais opacos. Apresenta granulação muito fina $(<0,5 \mathrm{~mm})$ (Fig. 28).
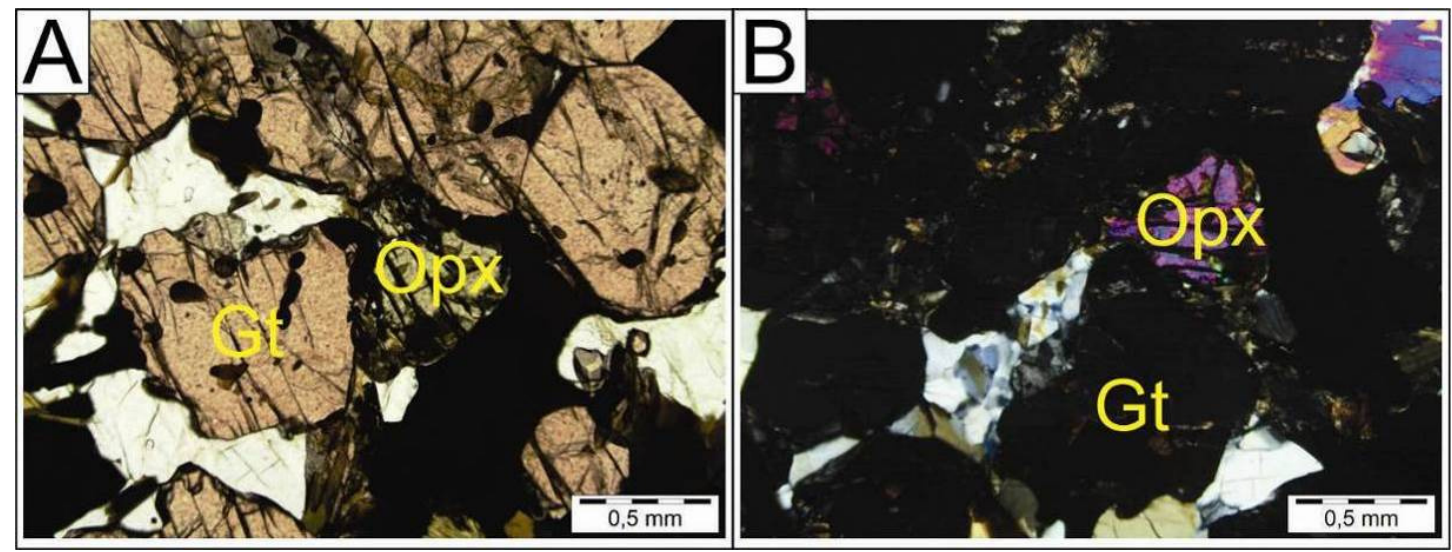

Fig. 28 - Fotomicrografia com ortopiroxênio intersticial a granada na matris do granada granulito máfico. Lâmina ALFE45Ib

Os feldspatos estão levemente alterados, com granulação fina ( 0,001-0,5 mm). O plagioclásio apresenta geminação polissintética com extinção ondulante ou com lamelas deformadas, gerando terminações em cunha. O plagioclásio pode ser antipertítico, com grãos xenoblásticos a subidioblásticos, com evidencias de migração de bordas dos grãos com formação de microgrãos nas bordas ou extinção irregular com formas de grãos, mas que foram agregados ao grão maior, e recristalização, em alguns casos, apresentam contatos poligonizados evidenciando equilíbrio. O quartzo apresenta-se em menor quantidade, formando grãos recristalizados xenoblásticos.

A biotita é pleocróica, com cor variando de marrom a bege claro, de granulação fina $(\sim 0,1-0,5 \mathrm{~mm})$, com formas tabulares orientadas segundo a foliação principal, se amoldando ao redor da granada, ou pode apresentar-se xenoblástica, tendo as bordas arredondadas quando inclusas na granada e nos minerais opacos. Pode ter substituindo a granada, por estar em suas bordas, quando esta fica com as bordas corroídas.

Os minerais opacos são xenoblásticos, de granulação média a grossa, com formas e contatos muito irregulares com a granada. 


\subsubsection{Hornblenda-granada granulito máfico}

O hornblenda-granada granulito máfico é migmatítico, de cor verde escura, granulação média a grossa $(\sim 1,0 \mathrm{~mm}$ a 3,0 mm), foliada, com leucossoma bem definido. O granulito apresenta textura nematogranoblástica, com foliação principal definida pelos grãos de hornblenda. O leucossoma apresenta textura granoblástica e porfiroblástica gerada por porfiroblastos de ortopiroxênio e granada. Quartzo e plagioclásio estão recristalizados, e texturas ígneas, com grãos euédricos desses minerais, são raras. O contato entre o leucossoma e o granulito é, em escala de lâmina, praticamente transicional, pois, embora seja bem delimitado, é a diminuição gradativa de hornblenda e piroxênios e o aumento de quartzo que definem esses limites (Fig. 29A). Muitas vezes na borda do leucossoma há acumulo de hornblenda formando selvedge (Fig. 29B).

O granulito apresenta granulação média $(0,5-3,0 \mathrm{~mm})$ e é composto por quartzo $(\sim 15 \%)$, feldspato potássico (ortoclásio) ( 10\%), plagioclásio, $\mathrm{An}_{27}$, oligoclásio $(\sim 10 \%)$, ortopiroxênio ( 5-20\%), granada ( 5-30\%), hornblenda ( 5-40\%), opacos ( 5-10\%) e acessórios (apatita, zircão) $(<1 \%)$. A hornblenda e biotita só estão presentes na porção granulítica da rocha (Fig. 29).

A hornblenda, presente apenas no granulito, tem pleocroismo variando de verde escuro a claro, com granulação fina a média $(0,2$ a 1,5 mm), é subidioblástica, orientada segundo a foliação principal gerando textura nematoblástica, com contatos retos entre si e lobado a interdigitado com os outros minerais. Apresenta inclusões de minerais opacos, quartzo e feldspatos.

Os grãos de ortopiroxênio do granulito são muito pequenos $(0,01 \mathrm{~mm})$ e fraturados, com bordas irregulares a alterada, xenoblásticos, levemente orientados segundo a foliação principal. No leucossoma apresentam pleocroismo variando de rosa a verde, são grãos subidioblásticos a xenoblásticos, com bordas variando de retas a irregulares, com contatos lobados com o quartzo e feldspato e interdigitado com os outros minerais. A porção alongada dos grãos está disposta paralelamente às paredes do leucossoma e formam porfiroblastos de granulação muito grossa $(>1 \mathrm{~cm})$. Possuem poucas inclusões, geralmente de quartzo arredondado e podem ter bordas substituídas por hornblenda e clinopiroxênio. (Fig. 30). 

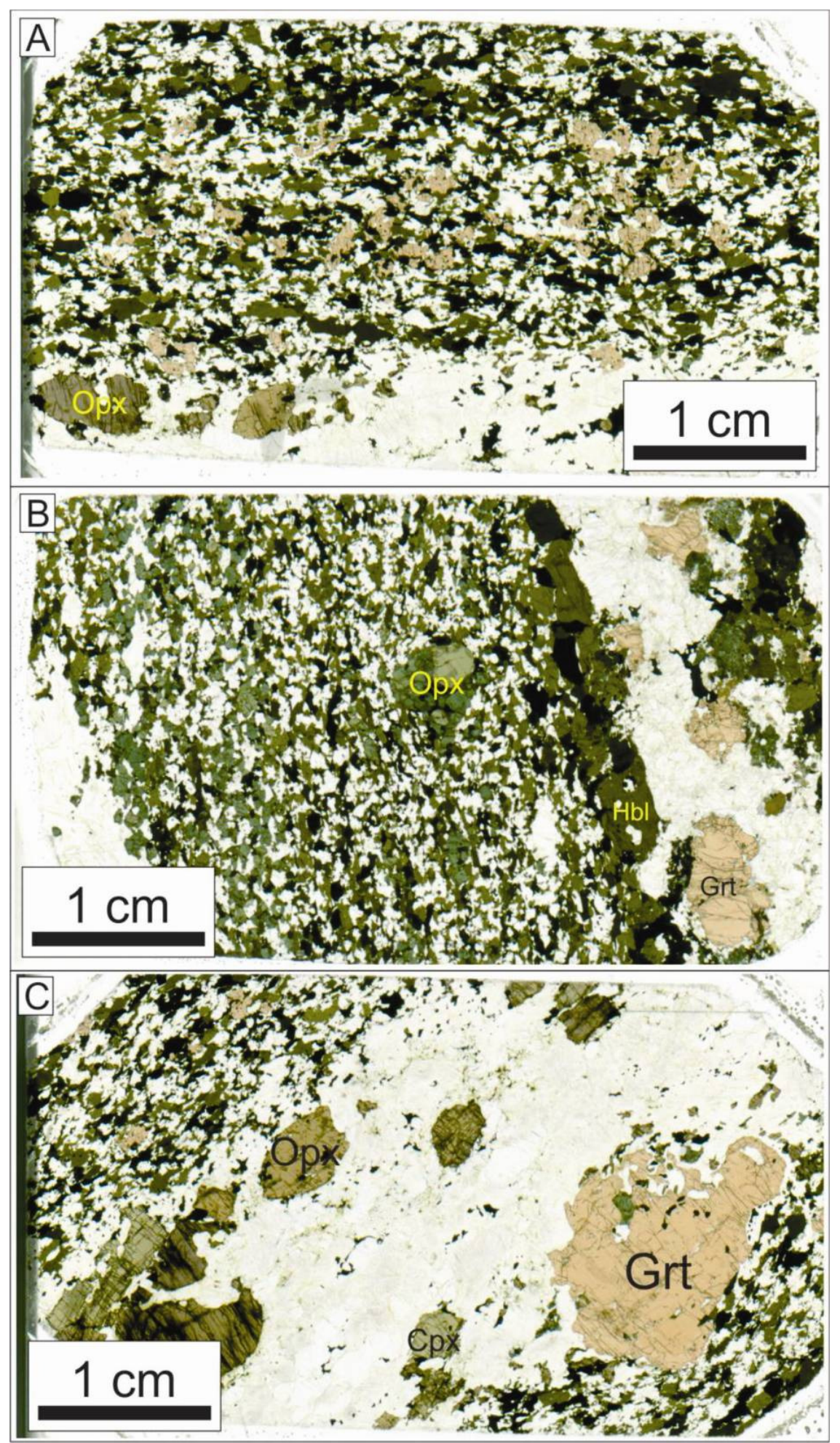

Fig. 29 - Lâminas digitalizadas para microssonda. Em A, mesossoma da rocha composto por quartzo, feldspatos, hornblenda, granada e ortopiroxênio (lâmina ALFE45Vb), em B e C, leucossoma com porfiroblastos de ortopiroxênio e granada, lâminas ALFE45Mb e ALFE45Va respectivamente. Notar que em B há acumulo de hornblenda entre o leucossoma e o mesossoma (selvedge). 


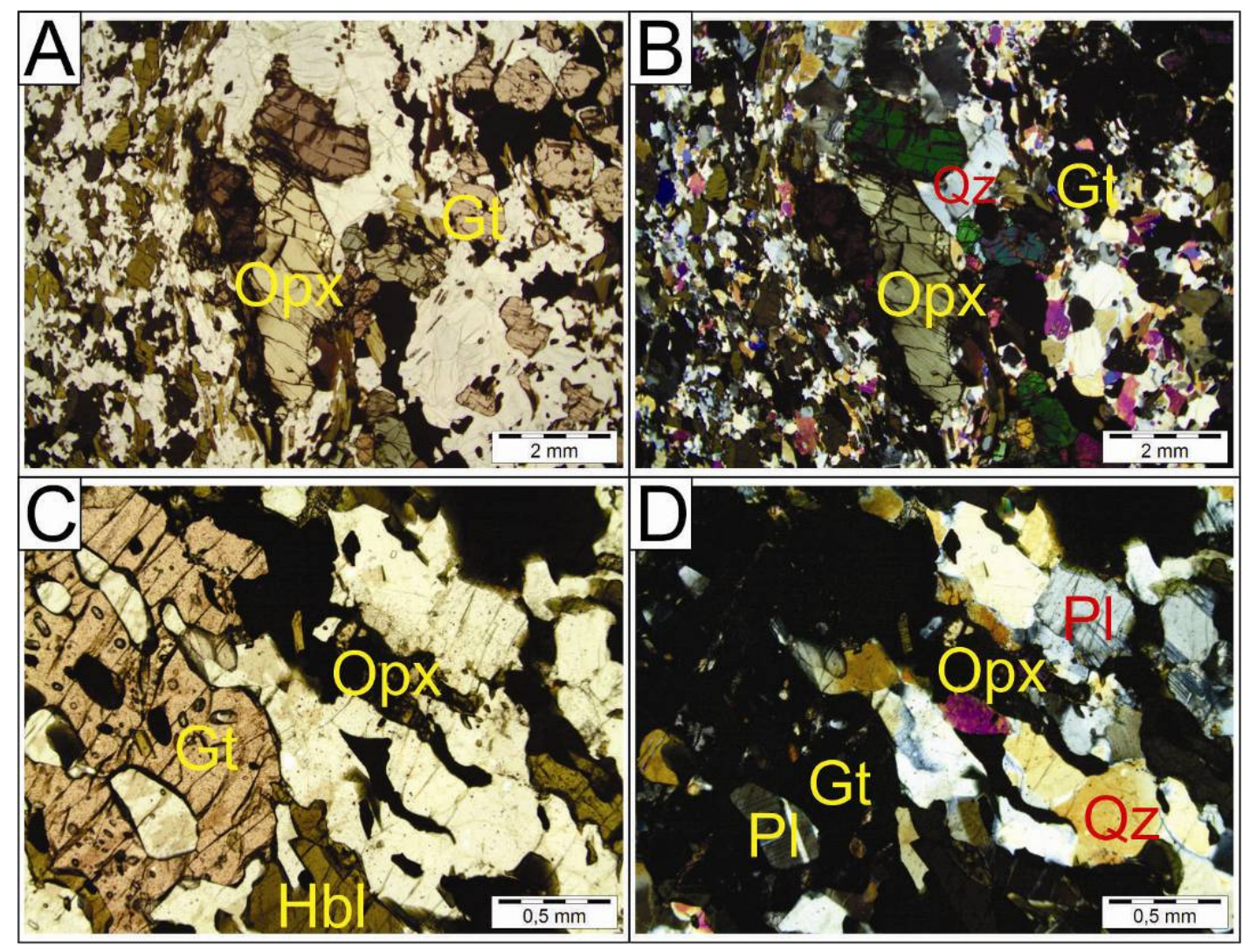

Fig. 30 - Fotomicrografia com polarizadores paralelos a esquerda e cruzados a direita. Em A e B porfiroblastos de ortopiroxênio no pequeno veio de leucossoma que separa o hornblendagranada granulito máfico do hornblenda granulito félsico (lâmina ALFE45Ib); Grãos de ortopiroxênio na matriz do hornblenda-granada granulito máfico em C e D (lâmina ALFE45Ib).

A granada é rosa, granulação heterogênea variando de média a grossa ( 1-5 mm) no granulito a muito grossa $(>1 \mathrm{~cm})$ no leucossoma, sendo que os porfiroblastos são subidioblásticos, com bordas e contatos suaves e poucas inclusões de quartzo, feldspatos e minerais opacos. No granulito, apresenta-se xenoblástica, com bordas irregulares, contatos lobados e com muitas inclusões de minerais opacos, quartzo e feldspatos arredondados (Fig. 31). 


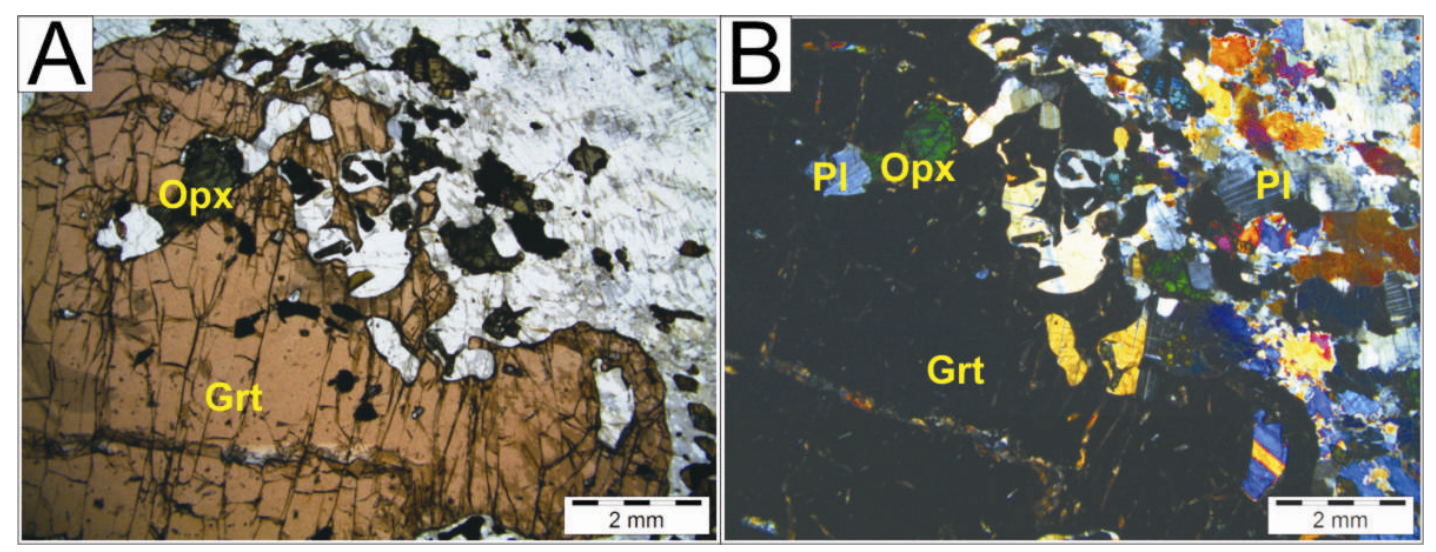

Fig. 31 - Fotomicrografia da lâmina ALFE45Va, onde a granada apresenta bordas irregulares, contatos lobados, poucas inclusões e muitas fraturas. Polarizadores paralelos e cruzados respectivamente.

Os grãos de quartzo e feldspatos são mais abundantes no leucossoma onde apresentam granulação média a grossa $(0,5$ a $5 \mathrm{~mm})$ e estão orientados segundo a foliação principal. No granulito apresentam menor quantidade e com granulação fina. O quartzo forma aglomerados de grãos recristalizados ou como grãos alongados segundo a foliação principal em textura flaser. O plagioclásio apresenta-se xeno- a subidioblástico, com contatos lobados entre si e interdigitado com os outros minerais, forma lamelas de exsolução de feldspato potássico e mirmequita com o quartzo no leucossoma. O feldspato potássico apresenta-se xeno- a subidioblástico, com contatos lobados, serrilhados e interdigitados, apresenta muitas lamelas de exsolução, formando pertita e mesopertita.

Os minerais opacos são xenoblásticos, às vezes redondos, levemente orientados, com contatos lobados com os outros minerais, podendo ser substituído por biotita ou estarem associados ao ortopiroxênio. Apresentam inclusões minúsculas de espinélio verde, de granada, biotita, quartzo e feldspato. Todas arredondadas podendo variar de tamanhos. Os minerais acessórios, zircão e apatita, variam de arredondados até euedrais, com hábitos prismáticos ou arredondados.

\subsubsection{Charnockito}

O charnockito ocorre como veios de leucossoma de espessura entre $5 \mathrm{~mm}$ até $3 \mathrm{~m}$, apresenta coloração verde acinzentada, de granulação grossa $(>3 \mathrm{~mm})$, com textura granoblástica ou ígnea, com porfiroblastos de ortopiroxênio, hornblenda, ou granada. É 
composto por quartzo ( 25-35\%), feldspato potássico ( 25-40\%), plagioclásio, $\mathrm{An}_{23}$, oligoclásio( $20-40 \%)$, ortopiroxênio $(\sim 5 \%)$, clinopiroxênio $(<5 \%)$, minerais opacos $(\sim 8 \%)$ e minerais acessórios, tais como zircão e apatita (Fig. 32).

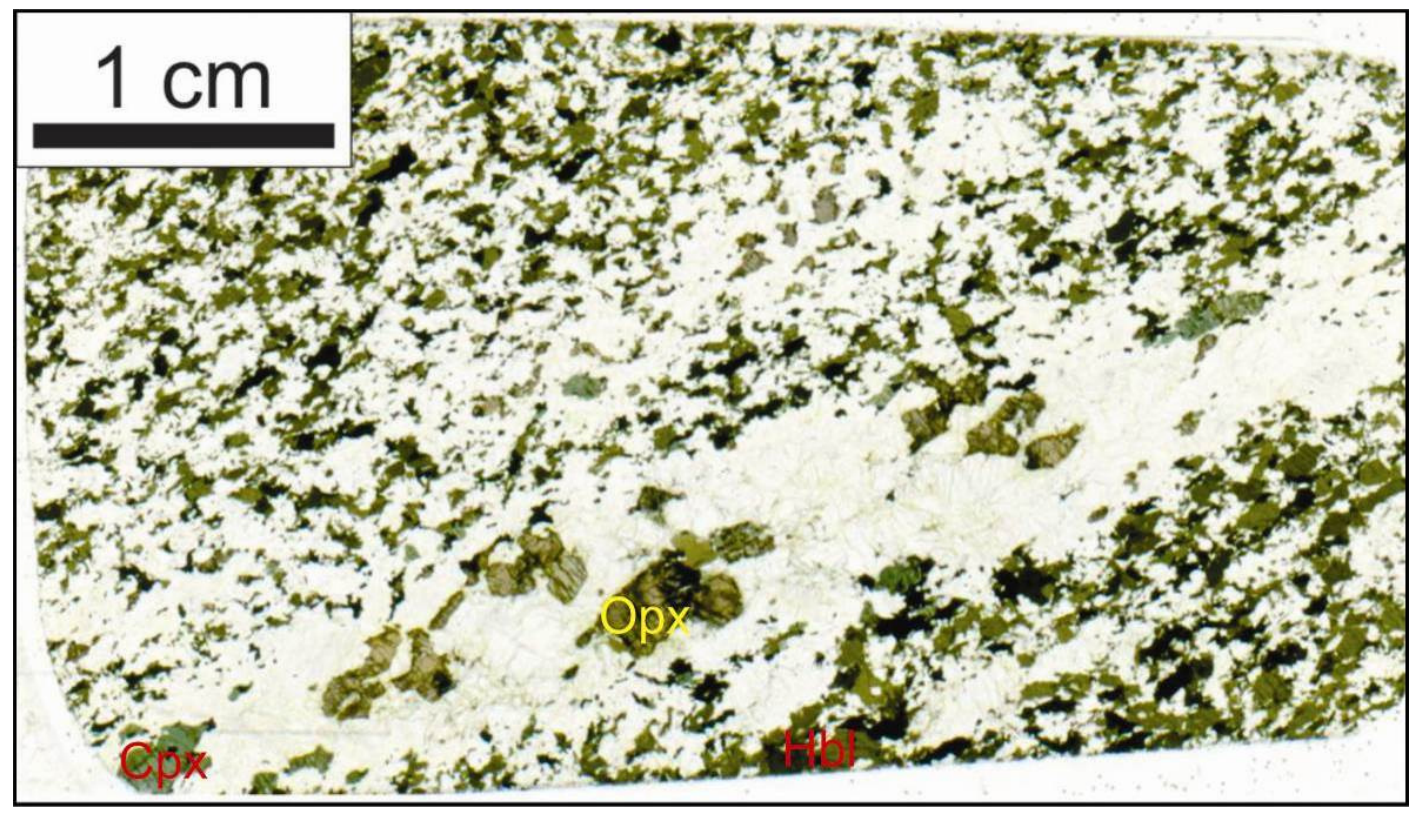

Fig. 32 - Lâmina digitalizada para microssonda do hornblenda granulito máfico com vênula de charnockito. Lâmina ALFE45N.

O quartzo é incolor a levemente azulado, o que dá cor a rocha em algumas amostras, com granulometria variando de média a grossa $(\sim 0,5$ a 3,0 $\mathrm{mm})$, formando grãos alongados segundo a foliação principal. O quartzo ocorre de forma intersticial entre os grãos de feldspatos e piroxênio. Apesar dos feldspatos terem hábito ígneo semi preservado, os grãos de quartzo podem ter muitos sub-grãos, tipo tabuleiro de xadrez, ou estarem recristalizados.

Os grãos de feldspato potássico são em grande parte subidiomórficos, com tamanhos variados, apresentam muitas lamelas de exsolução de todos os tipos como goticulares, ou em fitas onduladas, com contatos serrilhados com o plagioclásio, entre si e com quartzo.

O ortopiroxênio apresenta pleocroísmo variando de verde claro a vermelho claro, com granulação grossa $(\sim 3 \mathrm{~mm})$, formando fenocristais orientados, com formas euedrais a subeuedrais e bordas arredondadas, ou lobadas. Apresenta inclusões de minerais opacos e pode ter as bordas substituídas por clinopiroxênio. 
O clinopiroxênio apresenta cor verde clara, com pleocroismo fraco, com granulação fina a média $(\sim 0,3-1,0 \mathrm{~mm})$, formando fenocristais subédricos com bordas levemente irregulares e contatos lobados. Apresenta inclusões de minerais opacos, quartzo e ortopiroxênio.

Os minerais opacos ocorrem como inclusão nos piroxênios e os minerais acessórios, zircão e apatita, são subidiomórficos, a arredondados e estão distribuídos dispersamente pela rocha.

\subsubsection{Leucossoma granítico com hornblenda e biotita}

O leucossoma granítico com hornblenda e biotita apresenta cor rosa acinzentado, granulação grossa a muito grossa, localmente pegmatítica, com textura maciça a levemente foliada e com presença de feno a megacristais de hornblenda. É composto por quartzo ( 45\%), feldspato potássico ( 30\%), plagioclásio ( 30\%) (andesina), biotita $(\sim 5)$, hornblenda $(\sim 5 \%)$ e minerais opacos. Localmente é observada a transição entre os veios de charnockito para esse leucossoma, com mudança progressiva de cor e substituição dos piroxênios por hornblenda e biotita. Ainda é possível chegar a porções em que a rocha fica desprovida de minerais máficos e gera veios de granito hololeucocrático.

A hornblenda é verde escura a clara, com granulação muito grossa $(>2 \mathrm{~cm})$, com contatos retos e suaves e formas euedrais (Fig. 33), no entanto, em muitas lâminas revela ser constituída por simplectito de hornblenda, plagioclásio e quartzo, substituindo ortoou clinopiroxênio. A biotita verde a parda, associada à hornblenda pode substituir suas bordas ou quase que totalmente, com granulação muito fina, xenomórfica e com contatos retos, localmente forma grãos de mais de $5 \mathrm{~cm}$ (Fig. 33). 


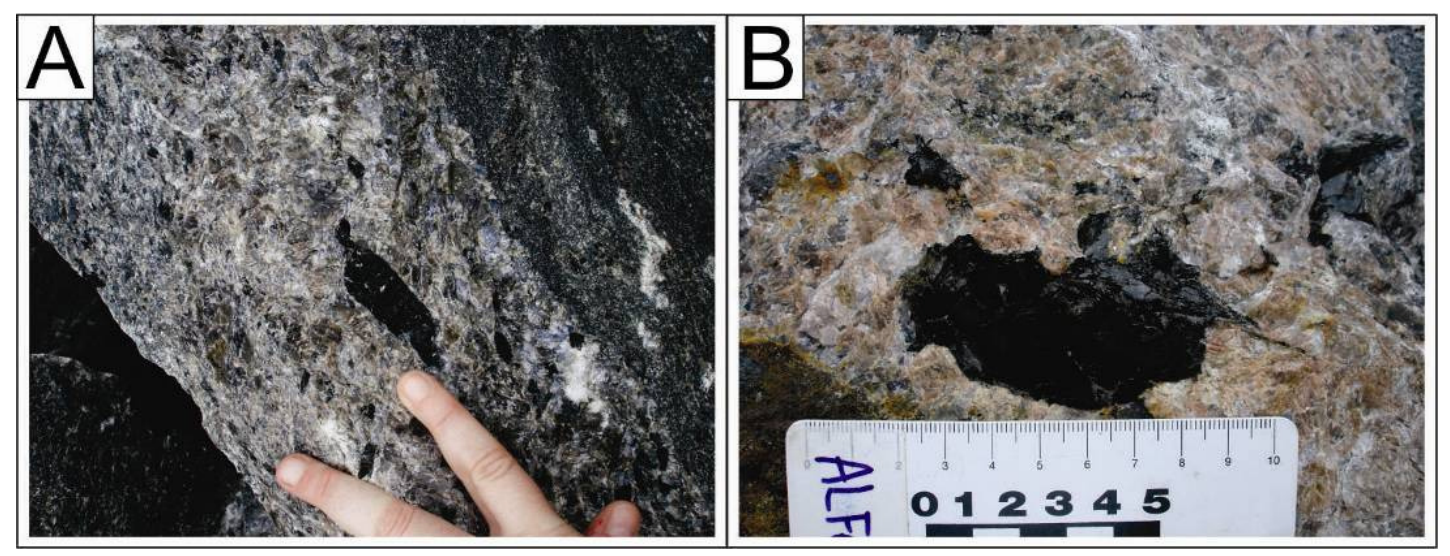

Fig. 33 - Megacristal de hornblenda euedral no leucossoma acinzentado em A e em B, megacristal de biotita em leucossoma rosa. Afloramento ALFE45-Pedreira Santa Terezinha.

O quartzo e os feldspatos apresentam granulação grossa a muito grossa (1,0 a 5 $\mathrm{cm}$, localmente são observados cristais de feldspato $>10 \mathrm{~cm}$ ), cores variando de branco acinzentado a rosa, com formas e contatos variados como reto, lobado, decussado e serrilhado. Os feldspatos apresentam bordas recristalizadas e muitas lamelas de exsolução entre eles e o quartzo pode formar microgrãos intersticiais.

\subsubsection{Unidade Diatexítica Intermediária}

A Unidade Diatexítica Intermediária é formada por diatexito nebulítico com rafts da rocha original, mas já totalmente modificada, além de porções com estrutura estromáfica, nas quais ocorrem lentes de granulitos máficos ou félsicos, as quais são descontínuas no campo. A rocha apresenta altas taxas de fusão, fazendo com que a mesma perca quase totalmente as estruturas originais, tornando-a com aspecto difuso e maciço e com características graníticas. Mas é possível diferenciar o diatexito de intrusões graníticas pela presença de porções preservadas da rocha e pela presença de estruturas pretéritas preservadas em rafts. A rocha que predomina na unidade é o diatexito, ora com hornblenda, ora com granada, ora com biotita, ou pela combinação de todos esses minerais.

Nessa unidade a rocha pode apresentar muitas estruturas, principalmente nos rafts, como bandamento composicional sem continuidade lateral, dobras com flancos rompidos, boudins do paleossoma granulítico, formação de bordas de reação tipo selvedge, 
schilieren, cristalização de porfiroblastos de granada e hornblenda em leucossoma, aspecto pegmatóide no granito, com cristais de até $5 \mathrm{~cm}$ de feldspatos (Fig. 34).
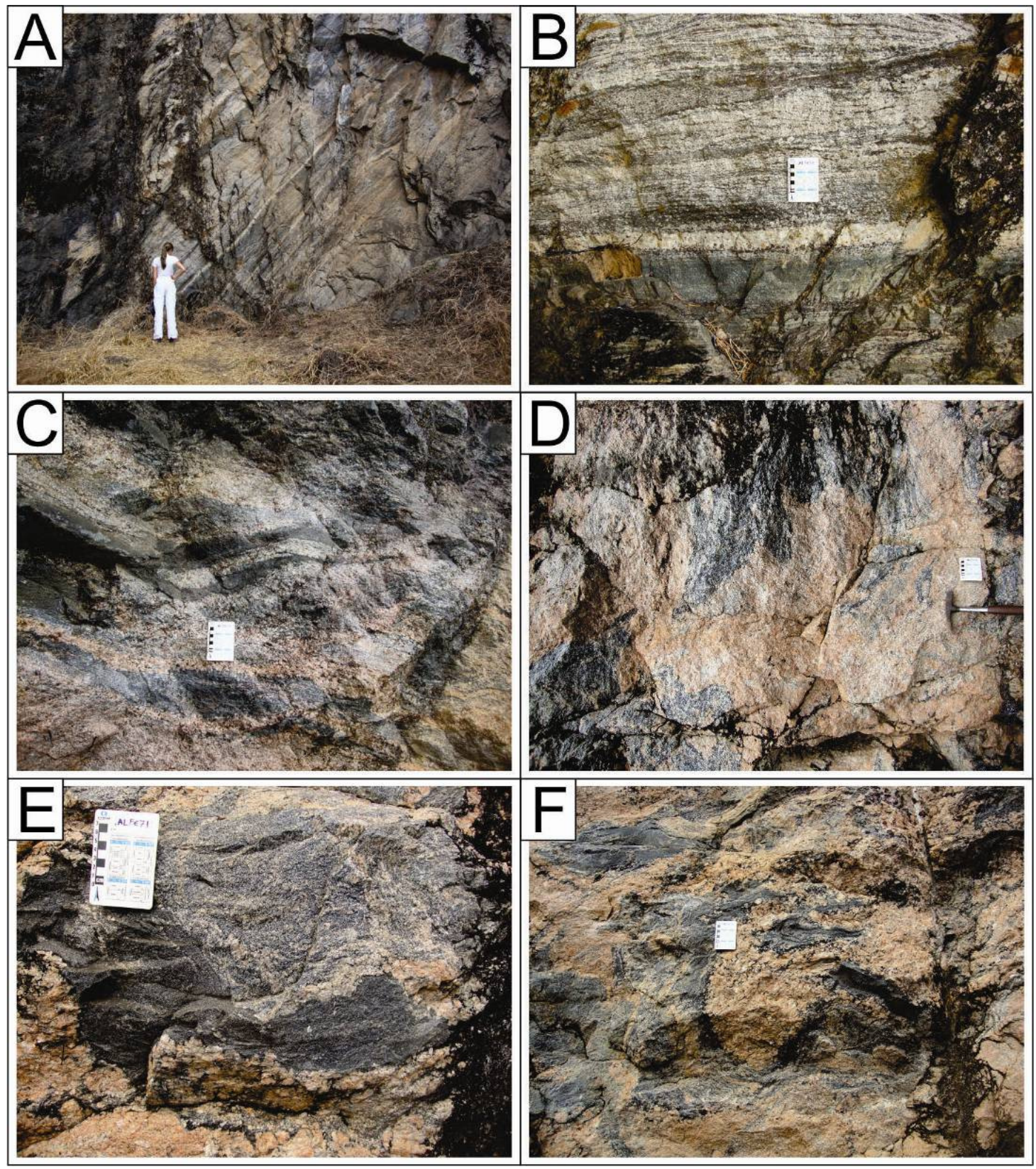

Fig. 34 - Fotos do afloramento ALFE71, pedreira abandonada próxima a rodovia MG-179. Em A, bandamento composicional mostrando porção não diatexítica; em B bandamento composicional preservado, detalhe para a camada de granulito máfico separada de gnaisse migmatítico por leucossoma com granada; em C, lentes de granulito máfico e anfibolito com formas irregulares, mantendo a orientação segundo a foliação principal; em D, rafts de granulito félsico com estrutura de bandamento dobrado preservada; em E, raft de granulito félsico e granulito máfico; em $\mathrm{F}$, formação de leucossoma in situ. 
O diatexito apresenta cor rosa, granulação grossa a muito grossa, com porções pegmatíticas, com textura maciça e presença de megacristais de granada de até $8 \mathrm{~cm}$. A rocha é composta por quartzo $(\sim 30 \%)$, feldspato potássico $(\sim 45 \%)$, plagioclásio, oligoclásio $(\sim 30 \%)$, biotita $(\sim 5 \%)$, hornblenda $(\sim 5 \%)$, granada $(\sim 10 \%)$ e minerais opacos. (Fig. 35).

A hornblenda verde escura a clara, com granulação grossa $(\sim 0,5$ a $1,0 \mathrm{~cm})$, com contatos e formas regulares, forma cristais subeuedrais. A biotita verde amarronzada, com granulação muito fina, xenomórfica e com contatos retos, substitui a hornblenda.

A granada apresenta-se euédrica a subeuédrica, arredondada, formando megacristais ou aglomerados de grãos. Apresenta bordas e contatos regulares a levemente alterados. Pode apresentar inclusões de biotita, quartzo e feldspatos arredondados e de minerais opacos. (Fig. 36).
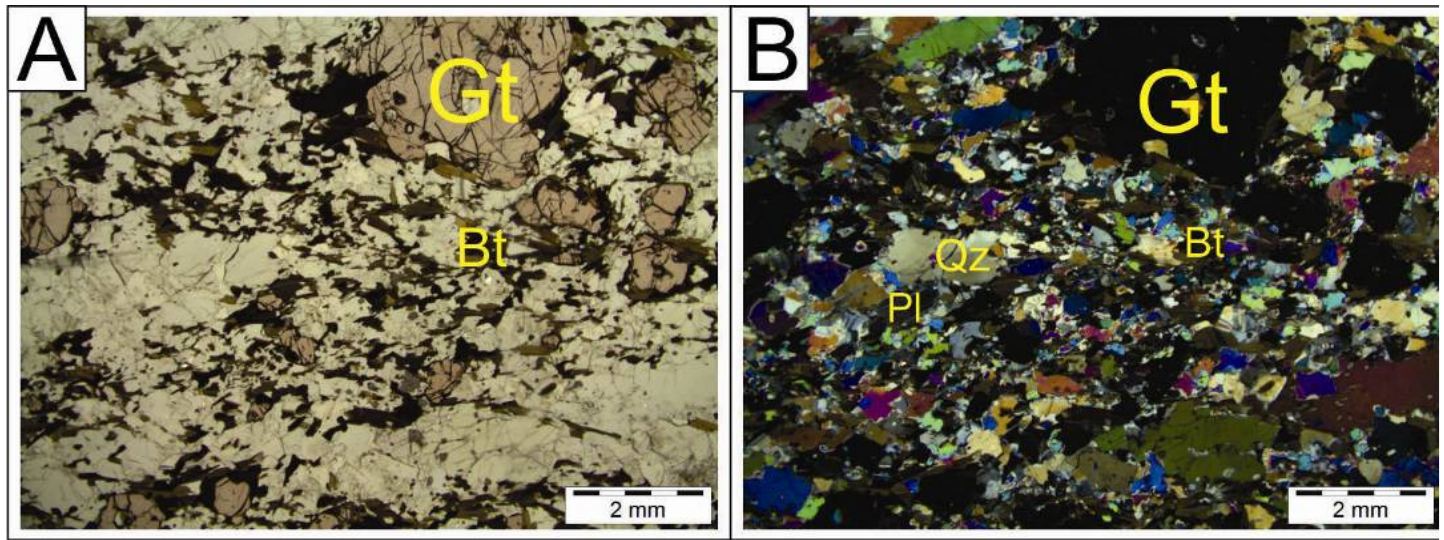

Fig. 35 - Fotomicrografias da lâmina ALFE24, com polarizadores paralelos e cruzados respectivamente. Foliação marcada por biotita e quartzo, na presença de porfiroblastos de granada. A biotita aparece envolvendo alguns grãos de granada.

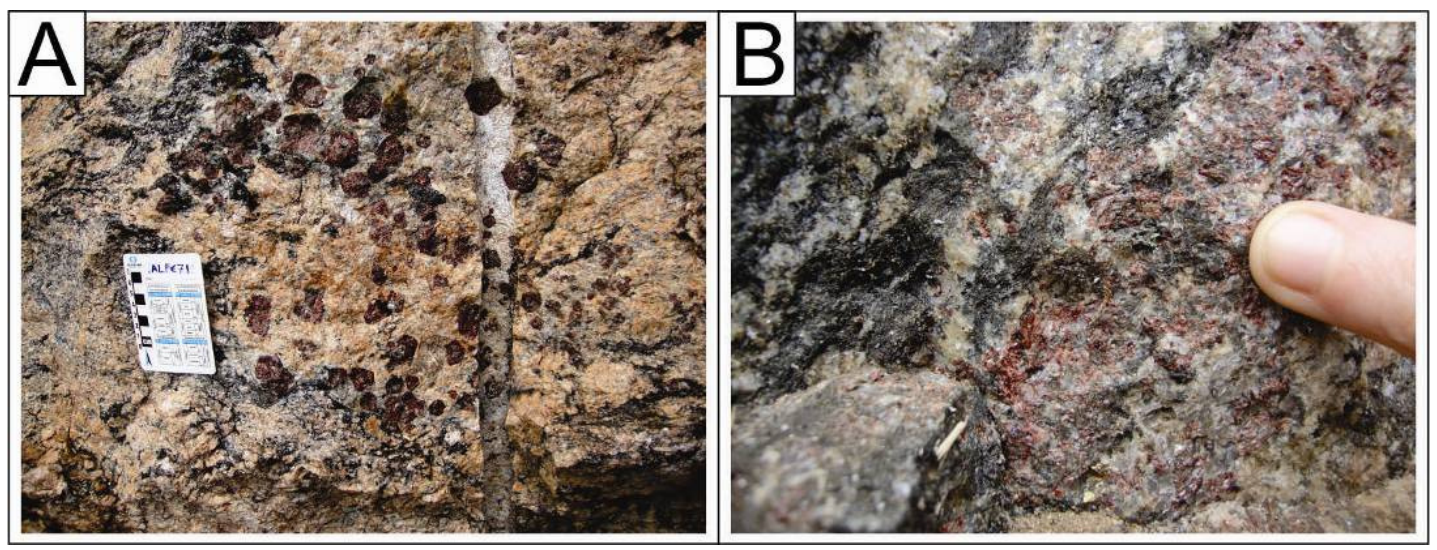

Fig. 36 - Fotos do afloramento ALFE71. Em A concentração de porfiroblastos de granada no leucossoma granítico, detalhe para porfiroblastos de granadas euédricos; em B, aglomerado de micro granadas em paleossoma. 
O quartzo e os feldspatos apresentam granulação grossa a muito grossa (1,0 a 5 $\mathrm{cm}$ ), cores variando rosa a laranja para o feldspato potássico e branco para o plagioclásio e incolor para o quartzo. Os feldspatos apresentam bordas recristalizadas e muitas lamelas de exsolução, mas em boa quantidade das lâminas descritas, os grãos são euédricos a subédricos, com quartzo intersticial, o qual pode estar recristalizado. (Fig. 37)

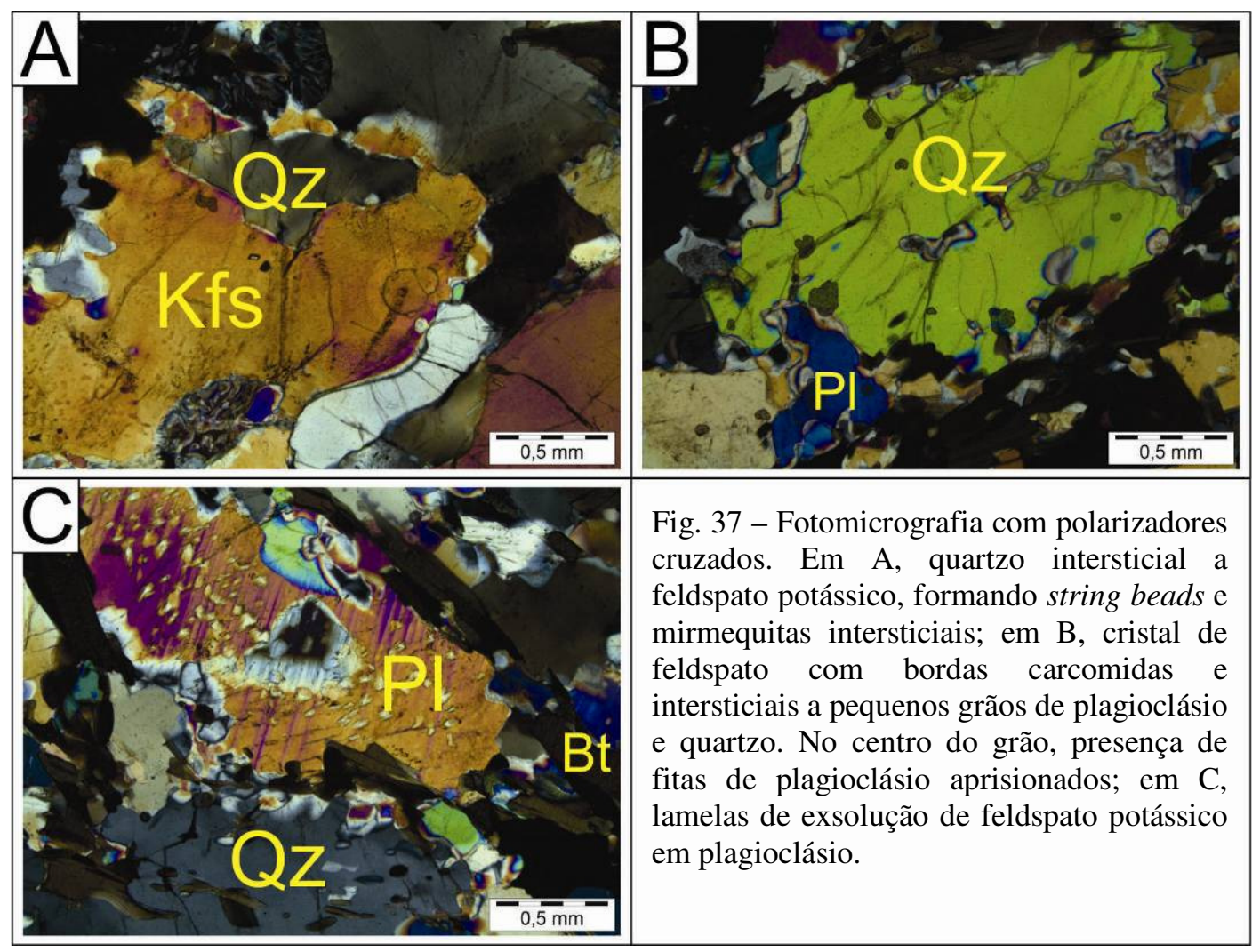

Os Rafts são porções preservadas da rocha original que são encontradas no meio do leucossoma granítico. Esse nome é dado pela forma que essas estruturas apresentam, como se fossem "canoas" boiando em granito. Geralmente preservam as estruturas da rocha anterior como bandamento composicional, dobras intrafoliais, parasitas e pitigmáticas. Podem formar bordas de reação, selvedge, quando em contato com o leucossoma. (Fig. 38). 


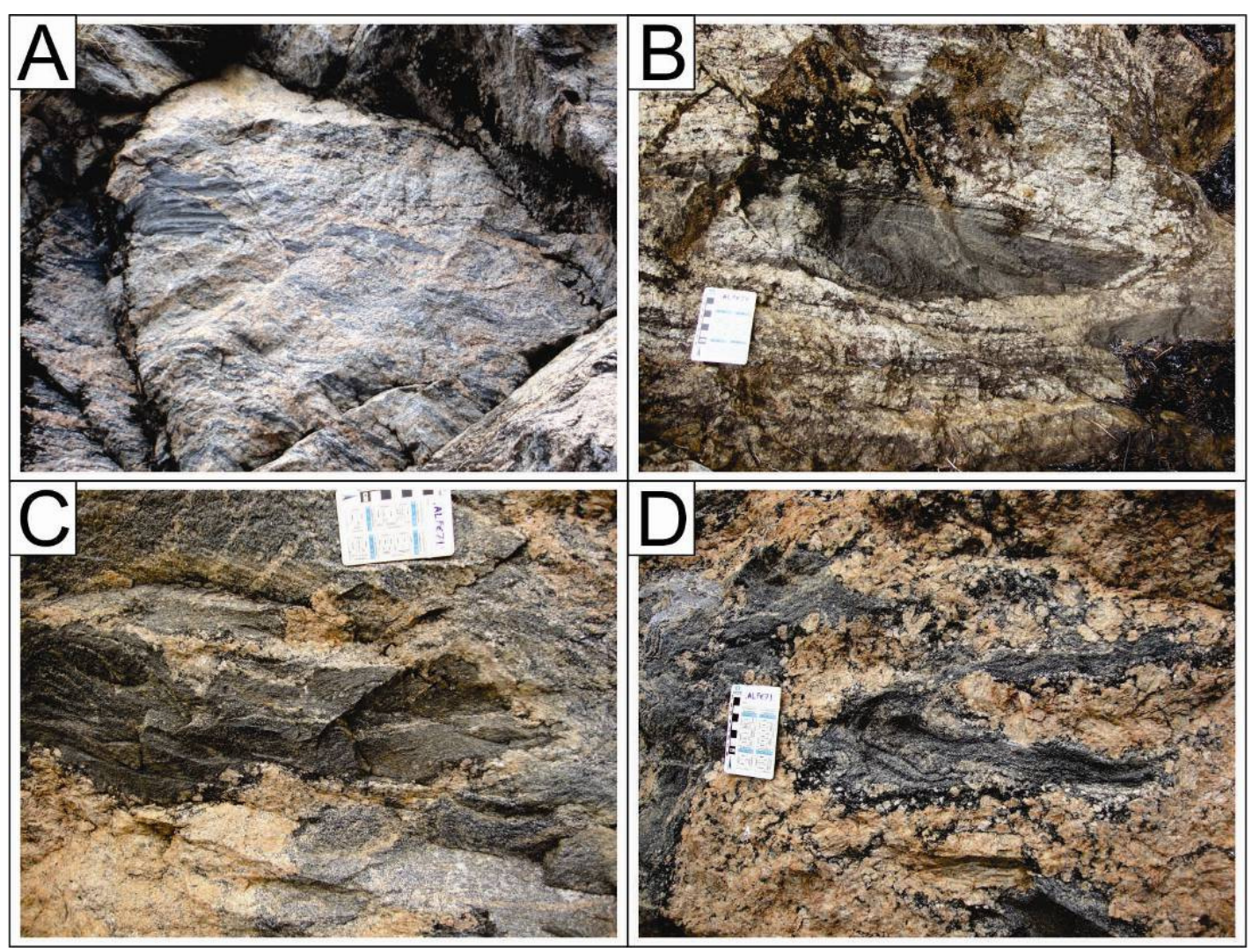

Fig. 38 - Foto do afloramento ALFE71, indicando os rafts no diatexito. Em A, começo de formação de rafts ainda apresentam-se orientados segundo a foliação principal com menor porcentagem de fundido entre eles; em B, boudin de anfibolito; em $\mathrm{C}$, boudin de anfibolito com borda de reação formando leucossoma; em D; raft de hornblenda granulito máfico bandado.

\subsubsection{Geologia Estrutural da Unidade da Nappe Socorro-Guaxupé}

Sendo a atitude média da foliação para as rochas da Nappe Socorro-Guaxupé de N88W/36SW (Fig. 39). Os resultados indicam que a foliação não varia muito entre as unidades e o mergulho das camadas aumenta gradativamente de sul para norte como mostrado no perfil (ANEXO 03). Com as lineações direcionais o resultado foi semelhante entre as unidades, com média de N78W/03. Os eixos de dobra são coincidentes com as lineações indicando que a direção de movimento que gerou as dobras foi o mesmo que gerou as lineações. 


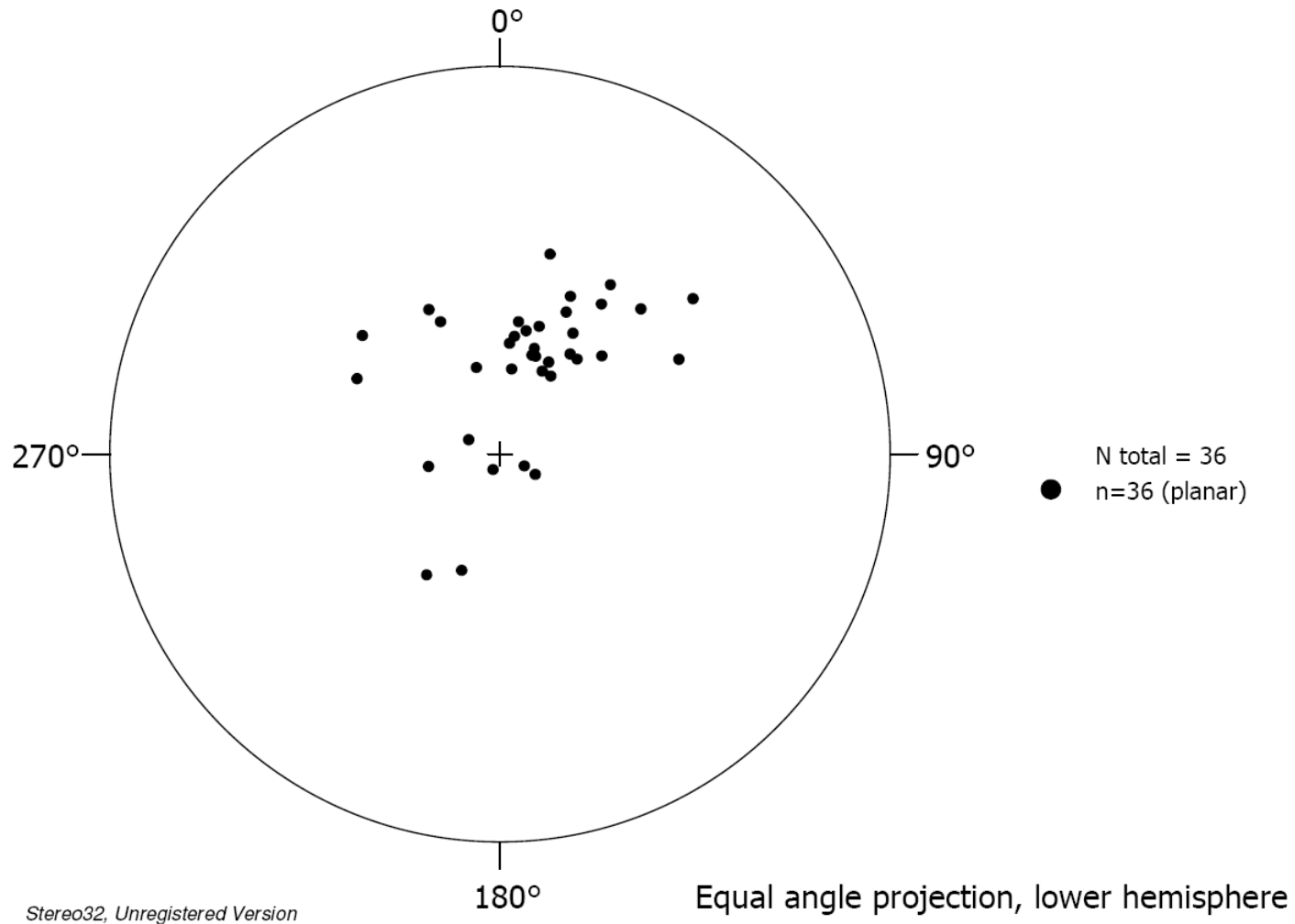

Stereo32, Unregistered Version

Fig. 39 - Projeção estereográfica da foliação $S_{2}$ da Nappe Socorro-Guaxupé. A foliação é plotada como polo e representada por pontos pretos no estereograma. Direção preferencial N88W/36SW.

\section{Química Mineral}

Após a petrografia algumas lâminas foram selecionadas para análise química de minerais com microssonda eletrônica, para investigação das variações químicas dos minerais nos litotipos principais investigados e para levantar dados para termobarometria.

A composição química dos minerais foi obtida usando a microssonda eletrônica JEOL-JXA8230 Super-Probe com cinco espectrômetros WDS para análises quantitativas e EDS, acoplado para análise semi-quantitativa, no Laboratório de Microssonda (LABSONDA) do Instituto de Geociências da Universidade Federal do Rio de Janeiro. As seguintes condições foram usadas para as análises: voltagem de $15 \mathrm{kV}$, corrente do feixe de 20,1 \pm 0,1 nA e como padrões foram usados minerais naturais. As fórmulas estruturais dos minerais analisados foram calculadas pelo programa Ax de Tim Holland e com o Microsoft Exel®.

As análises foram feitas em grãos selecionados em texturas e paragêneses diversas. Foram analisadas oito seções delgadas, onde ALFE24b pertence a unidade 
Campos Gerais, ALFE11, ALFE45Ib, ALFE45N, ALFE45V1 e ALFE45Va representam a unidade Granulítica da Nappe Socorro-Guaxupé e as seções ALFE71C e ALFE71E1 pertencentes a unidade Diatexítica da Nappe Socorro-Guaxupé. Foram feitos perfis ao longo dos grãos, análises pontuais e mapas composicionais para determinar a variação da composição do grão. Os resultados das análises estão apresentados no ANEXO 02.

\subsection{Granada}

A granada é um mineral importante para o estudo de rochas metamórficas por ser estável em quase todo intervalo de pressão e temperatura, podendo ser usada em cálculos $P-T$. O cálculo da fórmula estrutural foi baseado em 8 cátions e 12 átomos de oxigênio, o $\mathrm{Fe}^{3+}$ foi calculado com o balanço das cargas para que se obtenha exatamente essa proporção de cátions e oxigênios e para o cálculo dos membros finais da granada foram usados as expressões sugeridas por Deer et al. (1982):

$$
\begin{aligned}
& \text { Almandina }(\text { Alm })=\left[\mathrm{Fe}^{2+} /\left(\mathrm{Fe}^{2+}+\mathrm{Mg}+\mathrm{Mn}+\mathrm{Ca}\right)\right]^{*} 100 \\
& \text { Piropo }(\text { Prp })=\left[\mathrm{Mg} /\left(\mathrm{Fe}^{2+} \mathrm{Fe}+\mathrm{Mg}+\mathrm{Mn}+\mathrm{Ca}\right)\right]^{*} 100 \\
& \text { Esperssatita }(\mathrm{Sps})=\left[\mathrm{Mn} /\left(\mathrm{Fe}^{2+}+\mathrm{Mg}+\mathrm{Mn}+\mathrm{Ca}\right)\right]^{*} 100 \\
& \text { Grossulária }(\mathrm{Grs})=\left\{\left[\mathrm{Ca} /\left(\mathrm{Fe}^{2+}+\mathrm{Mg}+\mathrm{Mn}+\mathrm{Ca}\right)\right]^{*} 100\right\}-\mathrm{Adr} \\
& \text { Andradita }(\text { Adr })=\left[\mathrm{Fe}^{3+} /\left(\mathrm{Fe}^{3+}+\mathrm{Al}\right)\right] * 100
\end{aligned}
$$

\subsubsection{Granada do hornblenda-biotita-granada gnaisse migmatítico do Complexo Campos Gerais}

$\mathrm{Na}$ amostra do Complexo Campos Gerais (ALFE24B) foram analisados três grãos subidioblásticos, levemente arredondados, com inclusões arredondadas de quartzo e feldspato, contatos irregulares, e às vezes associados à biotita. Dois grãos (24b_Grt_01 e o 24b_Grt_02) estão na matriz e o outro (24b_Grt_03) encontra-se na interface da matriz com o porfiroclasto de feldspato. A composição da granada é rica em almandina (60-64,6 \%), com proporções medianas de grossulária (26- $4 \%$ mol) e baixos conteúdos de piropo $(<1,9 \%$ mol $)$ e espessartita $(0,7-1,02 \%$ mol $)$. Os perfis são planos, com pequenas diferenças da composição da borda para o centro. As concentrações de magnésio e manganês são as que apresentam menores variações ao longo dos grãos. No grão 24b_Grt_01 há empobrecimento de ferro em uma das bordas com aumento progressivo em direção a outra borda. O cálcio é também apresenta pouca variação ao longo do grão, 
com leve decréscimo em uma das extremidades (Fig. 40A). No segundo grão (24b_Grt_02) uma das análises pegou parte de uma inclusão gerando composição sem significado, a qual foi excluída. As bordas apresentam-se mais ricas em ferro com diminuição em direção ao centro. Próximo do ponto excluído a porcentagem de ferro aumenta. As bordas do grão são mais pobres em cálcio que aumentam progressivamente em direção ao núcleo. (Fig. 40B). O terceiro grão (24b_Grt_03) apresenta bordas mais ricas em ferro com diminuição em direção ao núcleo e o comportamento do cálcio é inverso ao do ferro (Fig. 40C).

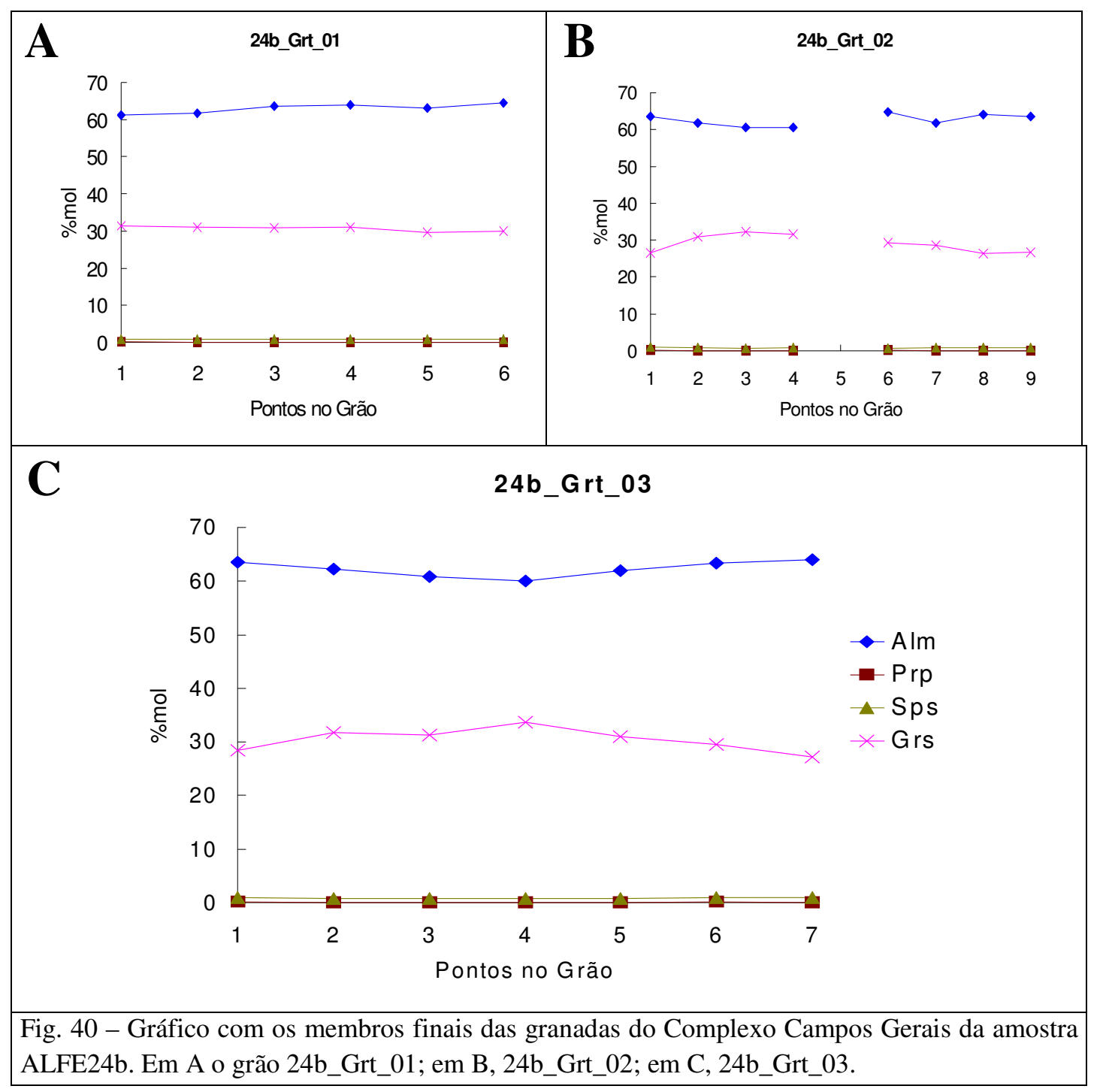




\subsubsection{Granada das rochas da Nappe Socorro-Guaxupé}

As seções delgadas selecionadas da Nappe Socorro-Guaxupé foram divididas em amostras da Unidade Granulítica (ALFE45Ib, ALFE45V1 e ALFE45Va) e da Unidade Diatexítica (ALFE71C e ALFE71E1).

\subsubsection{Granada da Unidade Granulítica}

$\mathrm{Na}$ amostra ALFE45Ib foram analisadas cinco grãos de granada subidioblásticos, com contatos suaves a retos, geralmente associados a biotita e com poucas inclusões arredondadas de quartzo e minerais opacos xenoblásticos. A granada 45Ib_GRT_01 e a 45Ib_GRT_02 encontram-se na interface do leucossoma com ortopiroxênio e o granada granulito, o grão 45Ib_GRT_03 foi excluído por apresentar valores de fechamento muito abaixo. Os outros grãos encontram-se na matriz do granada granulito. Todos os grãos apresentam valores maiores de almandina ( 53-57,5\%) e menores de piropo ( 17- 27\%), espessartita ( 9-11\%) e grossulária ( 10-17\%). Manganês apresenta pequenas variações em todos os grãos, mantendo perfil planar sem variações expressivas, já os outros componentes apresentam pequenas variações em todos os grãos. No grão 45Ib_GRT_01, as bordas apresentam maior concentração de ferro e menor concentração de magnésio e cálcio (Fig. 41A). O segundo grão, 45Ib_GRT_02, apresenta bordas mais ricas em ferro e mais pobres em magnésio e leve diminuição de cálcio no núcleo (Fig. 41B). O quarto grão é composto por dois grãos amalgamados, o primeiro (45Ib_GRT_04a) até o ponto 10 e o segundo (45Ib_GRT_04b), menor, do 10 ao 15. O grão 45Ib_GRT_04a apresenta aumento de ferro e diminuição de magnésio do núcleo para as, enquanto que cálcio é praticamente homogêneo. O grão 45Ib_GRT_04b apresenta características semelhantes ao grão 45Ib_GRT_04a (Fig. 41C-D). No quinto grão (45Ib_GRT_05) as bordas são mais ricas em ferro e proporcionalmente mais pobres em magnésio, com leve variação entre os pontos 10 e 14 onde a proporção de ferro e magnésio é inversa. Quantidades homogêneas de manganês e cálcio são observadas ao longo dos grãos, com o último com diminuição no ponto 9 (Fig. 41E). 


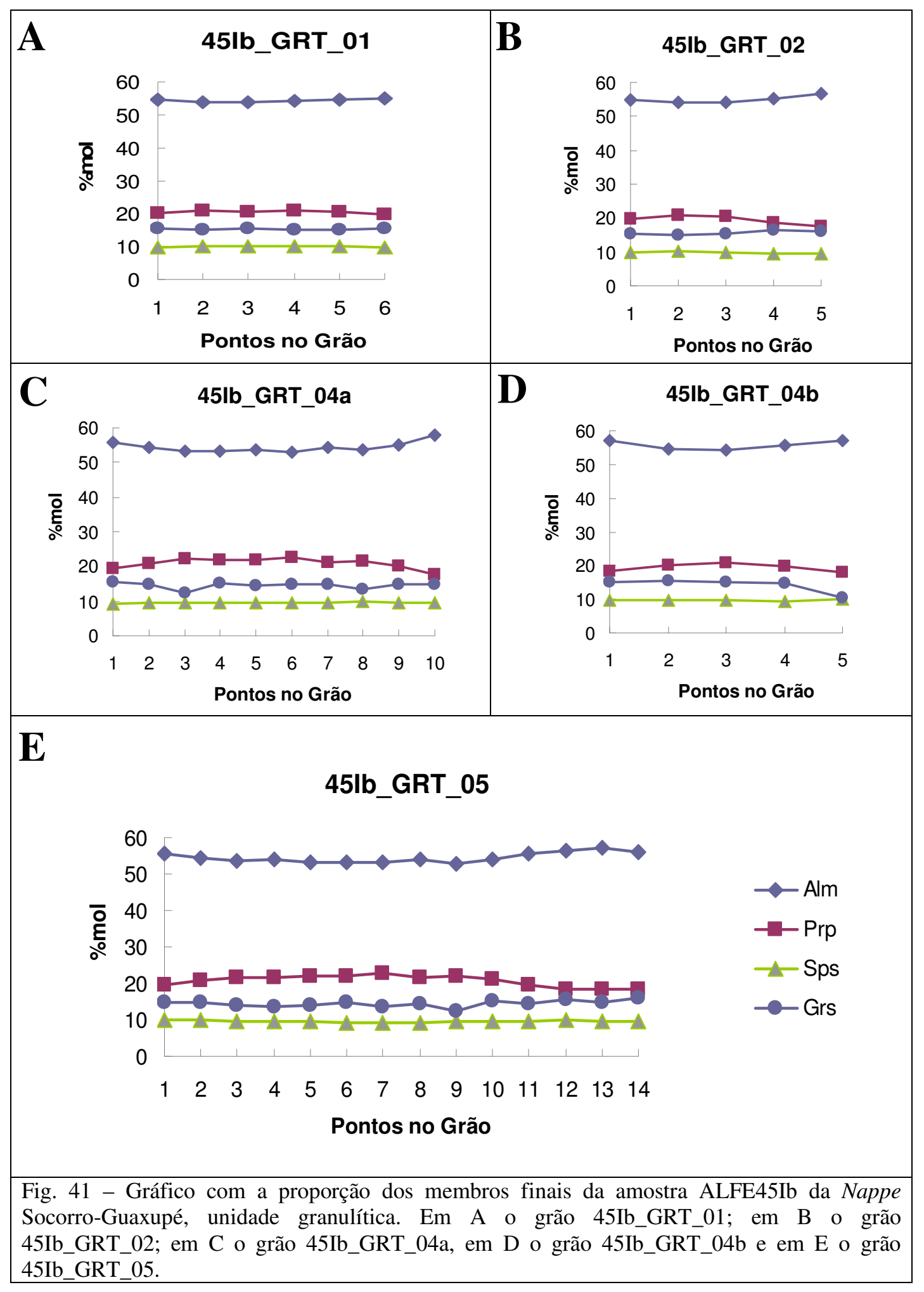


Na amostra ALFE45V1 foram selecionados três grãos, os dois primeiros na matriz do hornblenda-granada granulito e o segundo na interface com o leucossoma. Os grãos da matriz são xenoblásticos, com contatos lobados a interdigitados e com inclusões de quartzo xenoblástico ou arredondado. O grão na interface é subidioblástico, arredondado, com bordas suaves e contatos retos, não apresentando inclusão. Os grãos da matriz apresentam composição rica em almandina ( 49-54 \%), piropo ( 22,5-27 \%), grossulária $(\sim 16-19,5 \%)$ e espessartita $(\sim 4,7-6 \%)$. O comportamento do manganês em todos os grãos é similar formando perfil homogêneo sem variações da borda para o núcleo. Os outros elementos apresentam pequenas variações de acordo com os grãos analisados. No primeiro grão analisado na matriz (45V1_GRT_01) a proporção de ferro é maior em uma das bordas, diminui em direção ao núcleo, aumenta um pouco em direção a outra borda e volta a diminuir na borda. O comportamento do magnésio é inverso ao do ferro e o cálcio varia em uma das bordas com valor mais baixo, aumentando em direção ao núcleo, volta a decair na porção mais próxima da outra borda e eleva na borda (Fig. 42A). O segundo grão da matriz (45V1_GRT_02) apresenta bordas mais ricas em ferro, com diminuição em direção ao núcleo, tendo leve aumento no núcleo. Magnésio e cálcio apresentam comportamento inverso ao ferro (Fig. 42B).

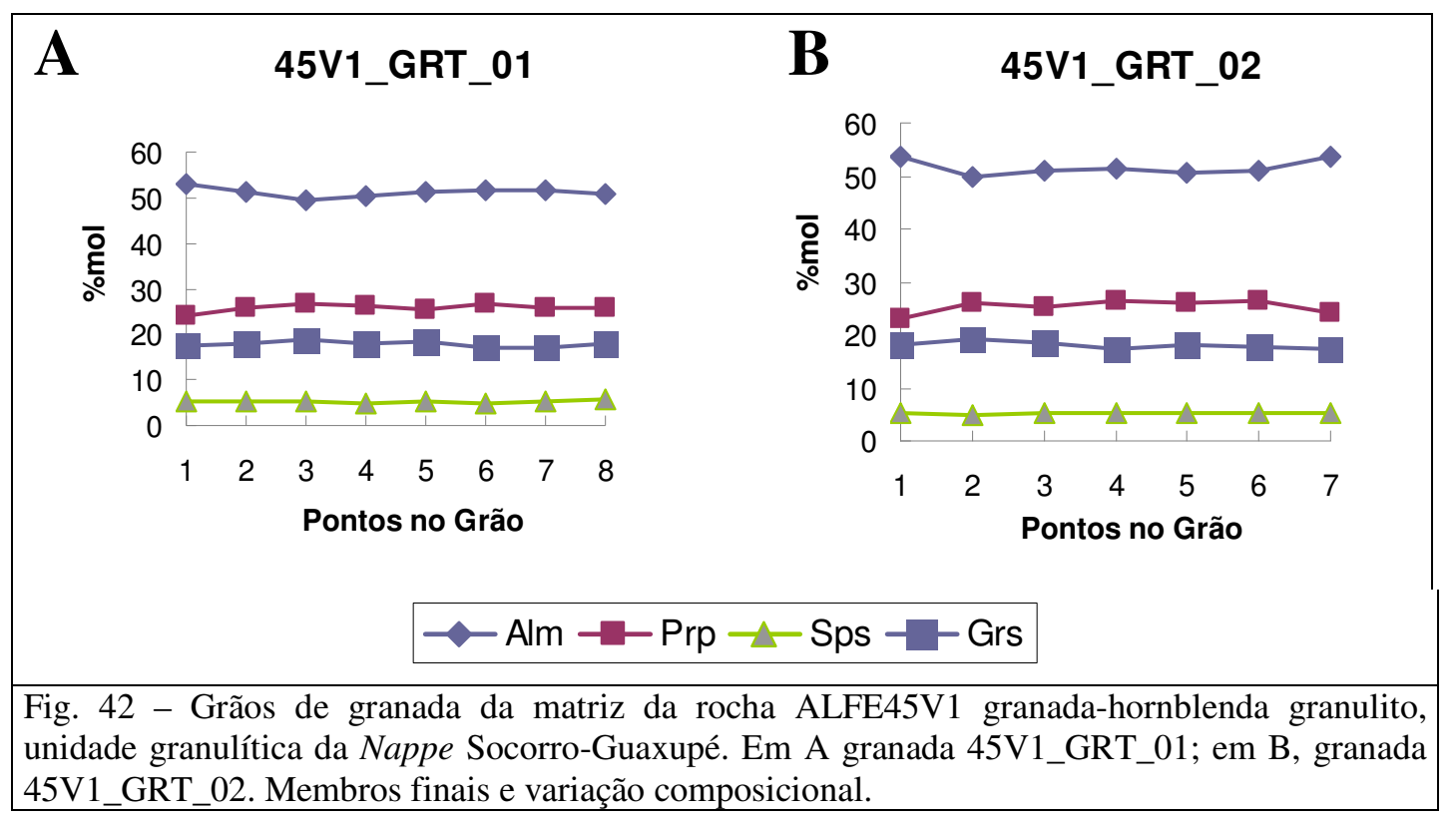

A granada analisada da interface leucossoma/granulito (45V1_GRT_03) apresenta almandina entre 51,45 e 53,46 \%, piropo entre 22,15 e 25,33 \%, grossulária 18,08 e 18,75 $\%$ e espessartita entre 4,85 e 5,64. A composição da granada é rica em almandina, com 
proporção de Fe maior nas bordas e inversamente proporcional ao magnésio. Teores de manganês e cálcio são homogêneos em todo o grão (Fig. 43).

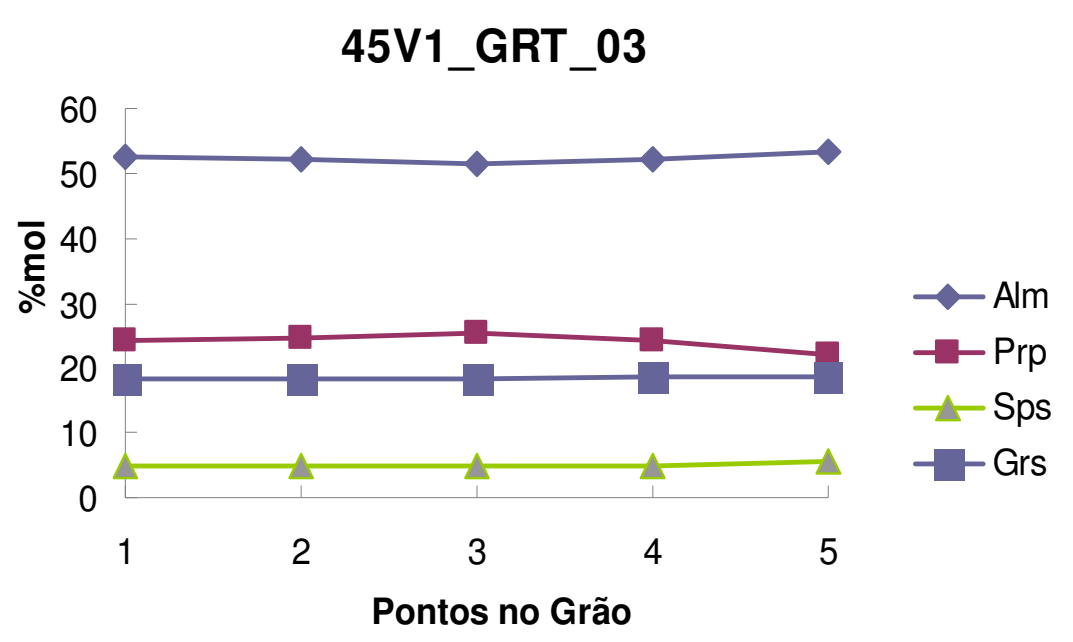

Fig. 43 - Granada 45V1_GRT_03 da interface leucossoma/granada-hornblenda granulito, unidade granulítica da Nappe Socorro-Guaxupé.

$\mathrm{Na}$ amostra ALFE45Va foi analisado um único porfiroblasto de granada (45Va_GRT_01), localizado na interface do leucossoma com o hornblenda-granada granulito. Apresenta-se xenoblástico, muito fraturado, com contatos irregulares e com inclusões de quartzo, feldspatos e minerais opacos. Observa-se pouca variação da composição ao longo do grão, sendo a composição dominada por almandina (50,50 $52,33 \%)$ e frações menores de piropo $(23,82$ - 26,75 \%), grossulária $(17,24-78,78 \%)$ e espessartita $(3,87$ - 4,43 \%). Há leve variação no ponto 20 em relação a ferro e magnésio. Uma das bordas apresenta menor concentração de ferro e magnésio e maior concentração de cálcio e manganês (Fig. 44). 


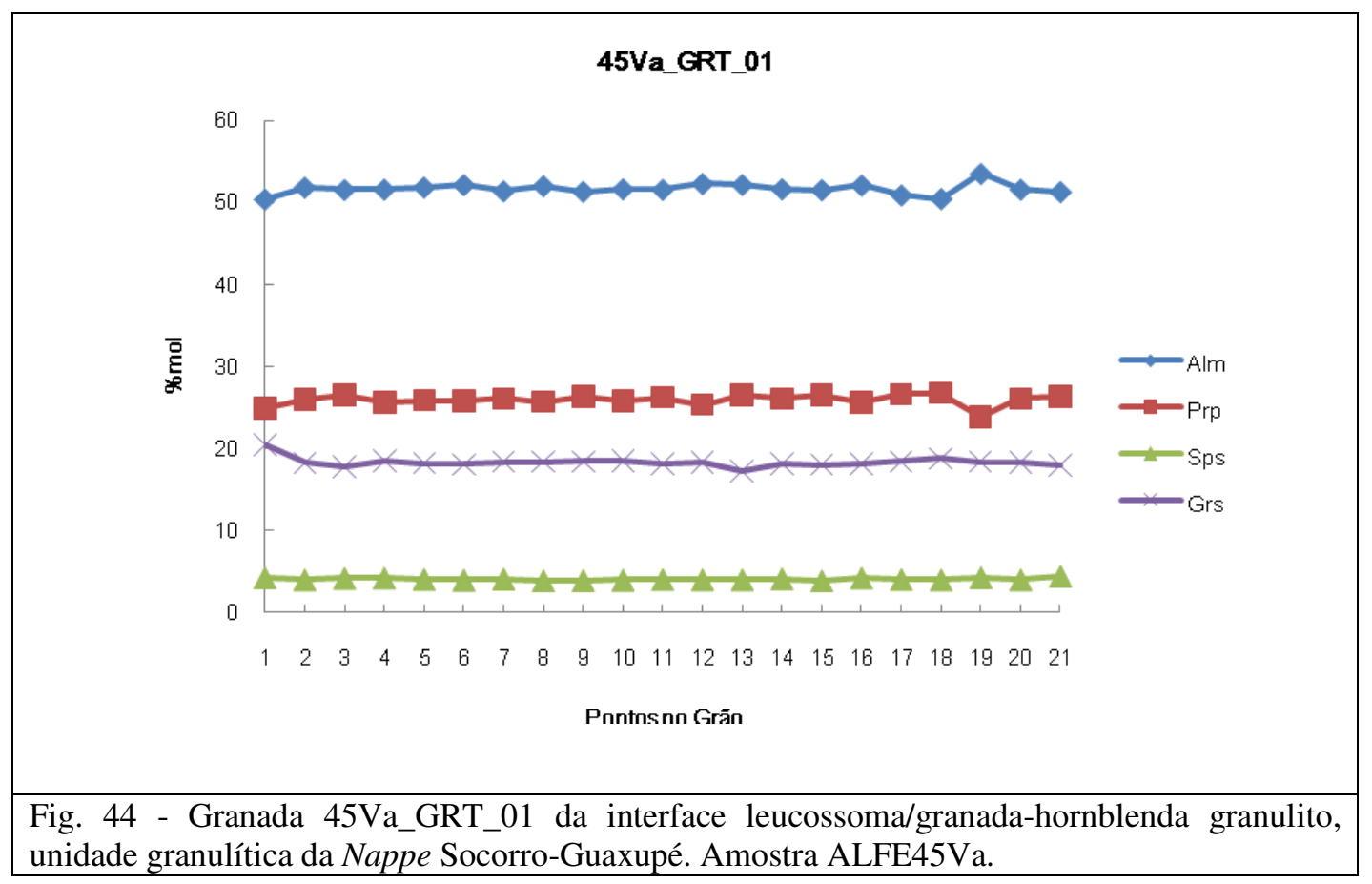

\subsubsection{Granada da Unidade Diatexítica}

A amostra ALFE71C representa o leucossoma da rocha onde três grãos subidioblásticos de granada e com contatos lobados e suaves foram analisados. Os grãos apresentam poucas inclusões e as vezes têm as bordas substituídas por biotita. $\mathrm{O}$ grão 71C_GRT_01 é formado pelo amalgamento de dois grãos, portanto as análises são divididas em 71C_GRT_01a, do ponto 1 a 6, e 71C_GRT_01b, do ponto 6 ao 12. Todos os grãos apresentam comportamento químico similar e são compostos principalmente por almandina ( 58-65,5\%), e proporções menores de piropo ( 19-28 \%), grossulária $(\sim 6,4-$ $10,6 \%)$ e espessartita ( 4,0-7,7 \%), com pouca variação composicional ao longo dos grãos. O primeiro grão apresenta concentrações de ferro maiores nas bordas e aumento de magnésio no núcleo, mais evidente no grão 71C_GRT_01a. A proporção de manganês ao longo do grão varia pouco, tendo no grão 71C_GRT_01a aumento relativo na borda em contato com o leucossoma, já em 71C_GRT_01b, não é verificada variação. As proporções de cálcio são homogêneas ao longo dos grãos com pequenas variações (Fig. 45 A e B). 


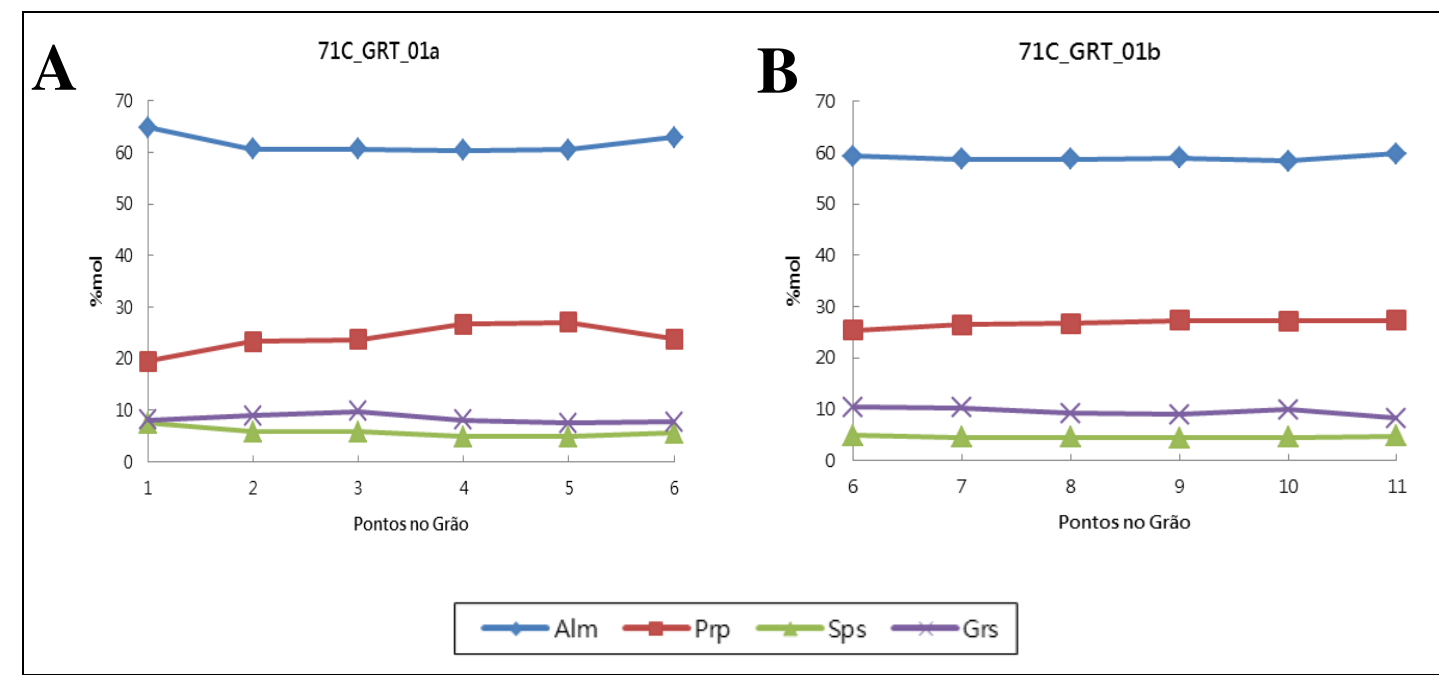

Fig. 45 - Granadas 71C_GRT_01a-b do leucossoma, unidade diatexítica da Nappe SocorroGuaxupé. Amostra ALFE71C com as razões dos membros finais e as variações composicionais ao longo do grão.

O segundo grão (71C_GRT_02) apresenta pouca variação de ferro e manganês ao longo do grão, com leve aumento de magnésio em uma das bordas. O cálcio apresenta comportamento heterogênio apresentando desnível entre o ponto 4 e 5 com diminuição em direção ao ponto 10 (Fig. 46 A). O último grão analisado (71C_GRT_03) apresenta comportamento decrescente de uma borda a outra em relação ao ferro e manganês, crescente em relação ao magnésio, proporcionalmente inverso ao ferro, e núcleo mais rico em cálcio (Fig. 46 B).

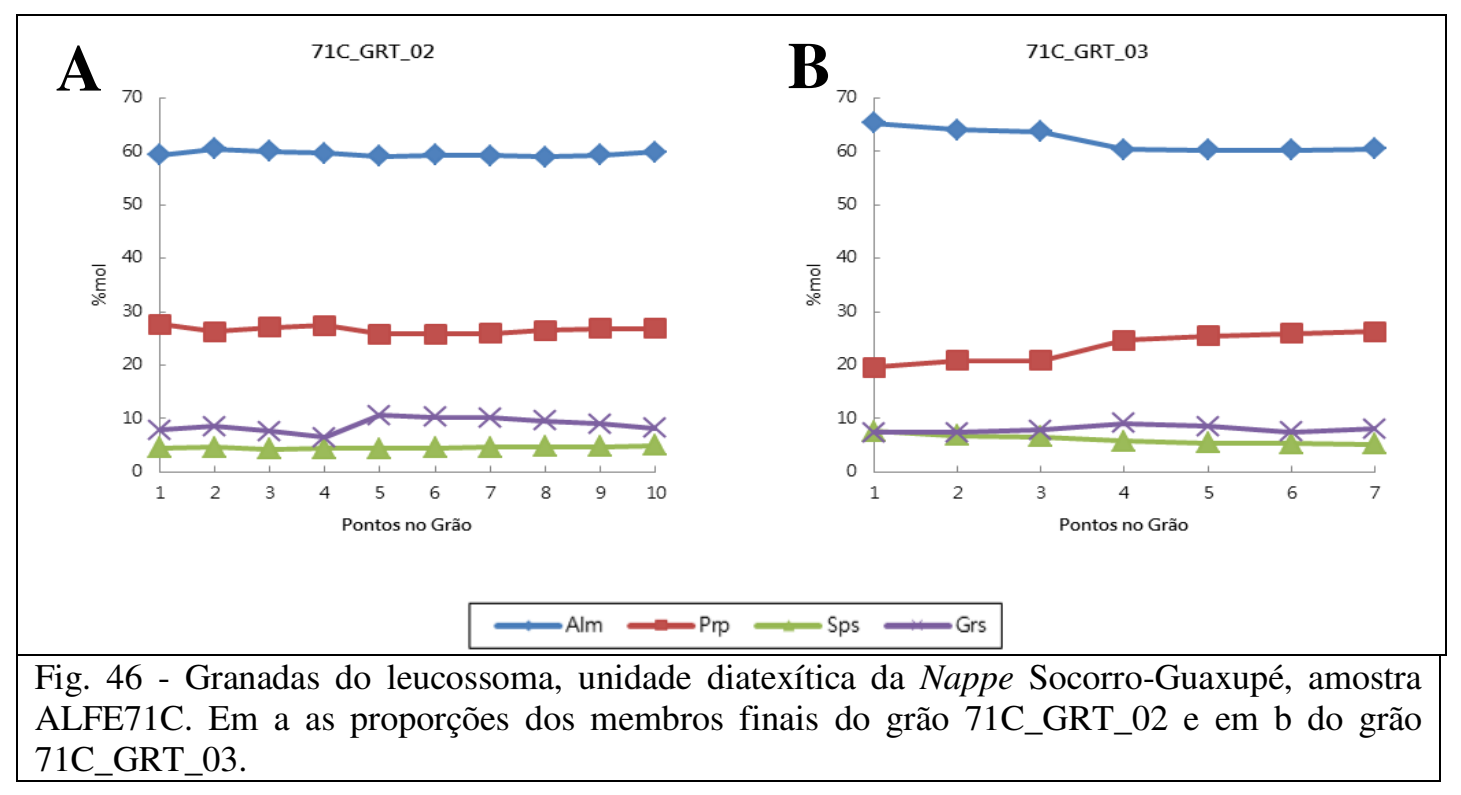


A outra amostra da unidade diatexítica é a ALFE71E1 onde foram analisados três grãos de granada, um na interface de leucossoma com o mesossoma e duas no diatexito. O primeiro (71E1_GRT_01) é porfiroblasto com forma arredondada, bordas irregulares, com inclusão de quartzo e minerais opacos e apresenta bordas substituídas por biotita. A composição é dominada por almandina $(58,44-63,51 \% 1)$, com proporções menores de piropo $(24,75-32,12 \%)$, grossulária $(4,50-10,97 \%)$ e espessartita $(3,12-3,80 \%)$. Manganês não varia ao longo do grão, com perfil plano, enquanto que ferro e cálcio apresentam aumento da concentração nas bordas, e diminuição de magnésio. $\mathrm{O}$ cálcio apresenta um núcleo mais rico, mas há um deslocamento da maior concentração em relação ao centro do grão (Fig. 47).

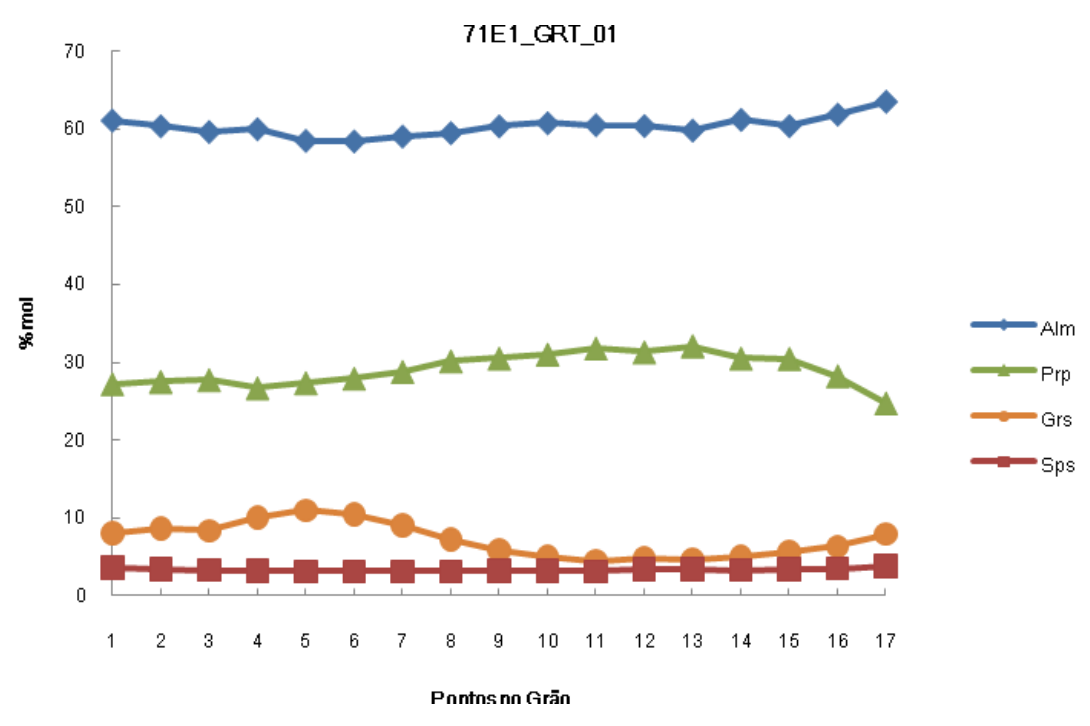

Fig. 47 - Granada 71E1_GRT_01 da interface entre leucossoma e matriz (mesossoma), unidade diatexítica da Nappe Socorro-Guaxupé. Amostra ALFE71E1 apresentando as frações dos membros finais da granada.

Os segundo e terceiro grãos são ovalados, levemente orientados segundo a foliação principal, com contatos lobados e suaves, com poucas inclusões de minerais opacos. O grão 71E1_GRT_02 apresenta um dos lados bordeado por biotita. Foi feito um perfil com oito pontos. As concentrações de almandina são as mais elevadas ( 60 - 64 $\%)$, médias de piropo $(\sim 21-28,5 \%)$ e baixas de espessartita $(\sim 3,44-4,34 \%)$ e grossulária $(5,25-10,28 \%)$. As variações composicionais são pequenas, com aumento de ferro e cálcio em direção às bordas e diminuição de magnésio, enquanto manganês é praticamente plano (Fig. 48). 


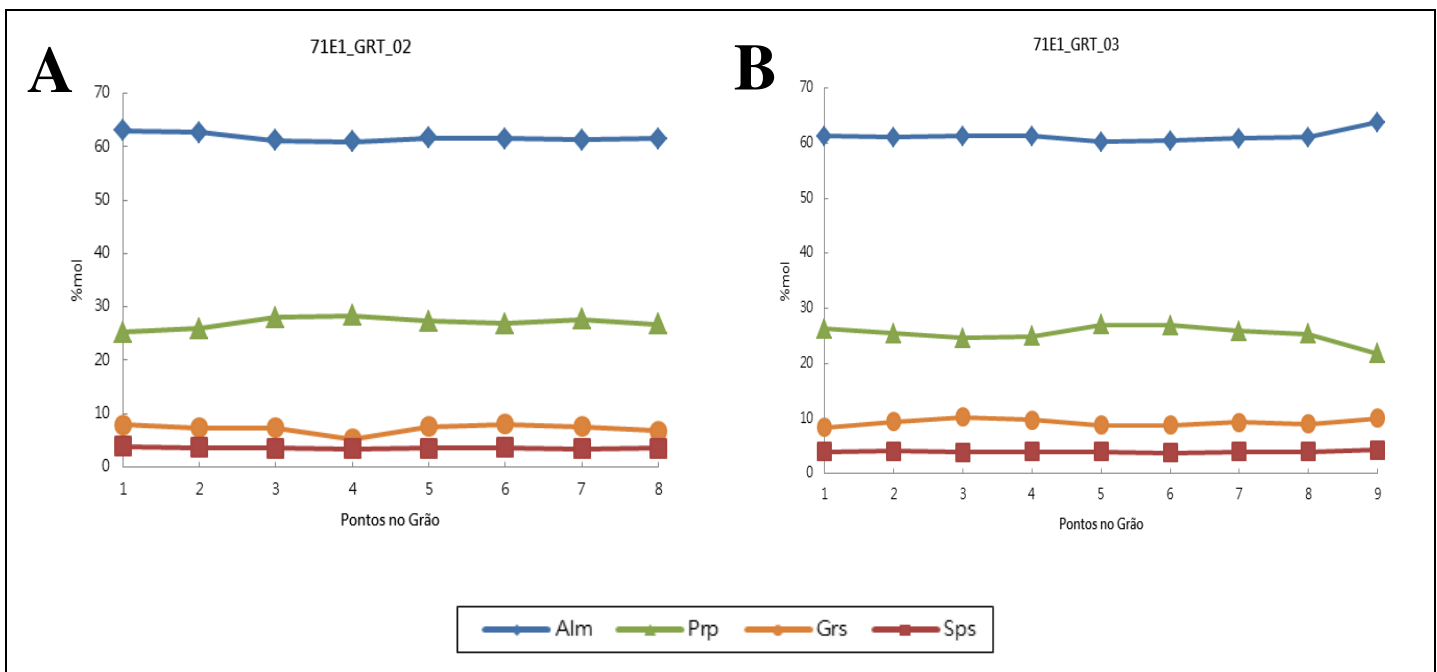

Fig. 48 - Granada da matriz (mesossoma), unidade diatexítica da Nappe Socorro-Guaxupé, amostra ALFE71E1, com razões molares dos membros finais e as variações composicionais ao longo dos grãos. Em A o grão 71E1_GRT_02 e em B o grão 71E1_GRT_03.

\subsection{Piroxênios}

Os piroxênios são muito importantes por ocorrer em quase todos os tipos de rochas ígneas e metamórficas de temperatura média a alta. Piroxênios são silicatos que contêm cadeias simples de $\mathrm{SiO}_{3}$ formadas por tetraedros de $\mathrm{SiO}_{4}$ interligados pelos vértices. Geralmente, pequenas quantidades de Si são substituídas por Al ou outros cátions pequenos. A repetição ao longo da cadeia (eixo c) compreende dois tetraedros e tem comprimento aproximado de $0,52 \mathrm{~nm}$. A fórmula química geral para todos os piroxênios é (M2)(M1)T2O6, onde M2 se refere a cátions em coordenação octaédrica geralmente distorcida, como $\mathrm{Na}, \mathrm{Ca}, \mathrm{Mn}, \mathrm{Fe}$ e $\mathrm{Mg}$., quando sítio M2 é totalmente ocupado, o Fe restante entra no sítio M1. M1 se refere a cátions em coordenação octaédrica regular, sendo os mais comuns: $\mathrm{Al}, \mathrm{Ti}, \mathrm{Mg}$ e Fe, e T a cátions em coordenação tetraédrica (Garda, G. M.; Atencio, D., 1990).

Podem ser divididos em três grupos, um cristalizado no sistema ortorrômbico originando os ortopiroxênios, outra no sistema monoclínico gerando os clinopiroxênios e a terceira no sistema triclínico, denominada piroxenóide. Os piroxênios são classificados de acordo com o cátion que ocupa o sítio M2, podendo ser sódico, cálcico ou ferromagnesiano (Fig. 49). 


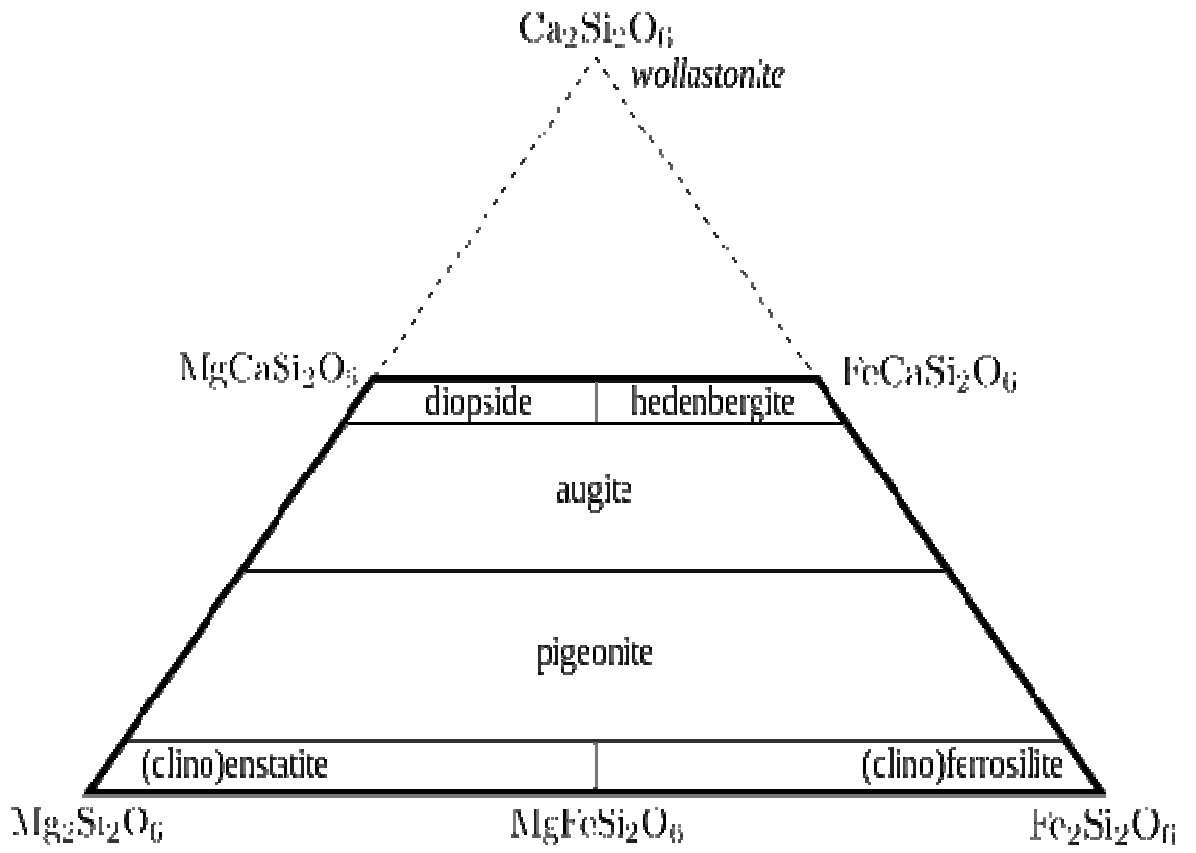

Fig. 49 - Diagrama com intervalos de composições de piroxênios.

\subsubsection{Ortopiroxênio}

O ortopiroxênio é considerado o mineral índice para o fácies granulito. Quando o sítio M2 é ocupado por Fe ou Mg o piroxênio entra no grupo dos ortopiroxênios, para os quais predominam as substituições FeMg $g_{-1}$, a tschermakíticas $\left(\mathrm{Al}^{\mathrm{VI}} \mathrm{Al}^{\mathrm{IV}} \mathrm{Mg}_{-1} \mathrm{Si}_{-1}\right)$ e, em menor quantidade, $\mathrm{CaMg}_{-1}$ (Fig. 50).

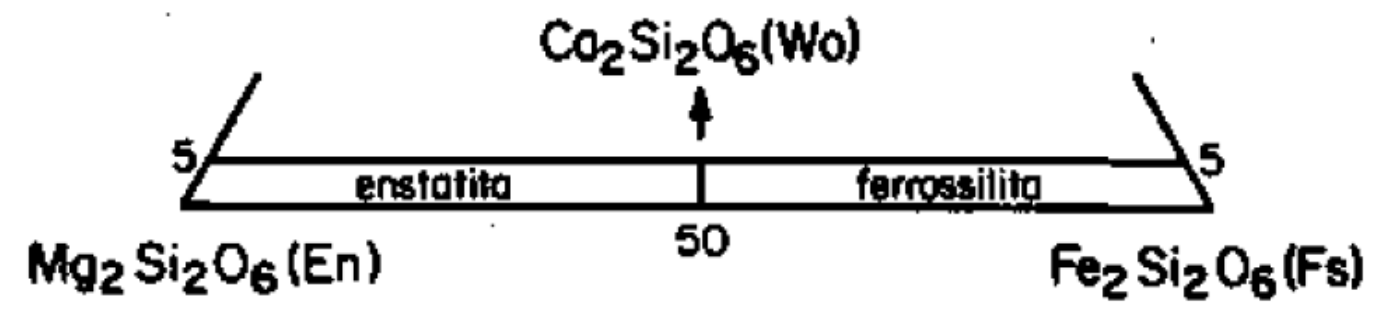

Fig. 50 - Intervalos de composições de ortopiroxênios com nomes aceitos 
Os grãos de ortopiroxênio analisados pertencem aos granulitos da unidade granulítica da Nappe Socorro-Guaxupé, por serem petrograficamente mais adequados para os cálculos termobarométricos. Quatro amostras foram selecionadas: ALFE11a, ALFE45Ib, ALFE45N e ALFE45V1, representativas de todas as rochas da unidade.

A amostra ALFE11a é um granulito félsico bandado onde foram analisados três grãos, um no leucossoma e dois no granulito. O grão do leucossoma é subidioblástico, arredondado, com fraturas e bordas alteradas e os grãos do granulito são xenoblásticos, levemente alongados segundo a foliação principal, com contornos e bordas irregulares. Ao longo dos grãos, em ambos os tipos, não há variação química muito expressiva de $\mathrm{Al}^{\mathrm{IV}}, \mathrm{Al}^{\mathrm{VI}}$ e $\mathrm{X}_{\mathrm{Mg}}$ (Fig. 51A-C), sendo o comportamento de $\mathrm{Al}^{\mathrm{IV}}$ inversamente proporcional ao $\mathrm{Al}^{\mathrm{VI}}$. Em relação às trocas catiônicas $\mathrm{FeMg}_{-1}$ e $\mathrm{AlMg}_{-1}$ (Tschermak) é evidente que o grão do leucossoma (11a_OPX_01) é mais rico em Fe e Al do que os do granulito (11a_OPX_02 e 11a_OPX_03), como pode ser observado nas Figuras 52A e 52B.

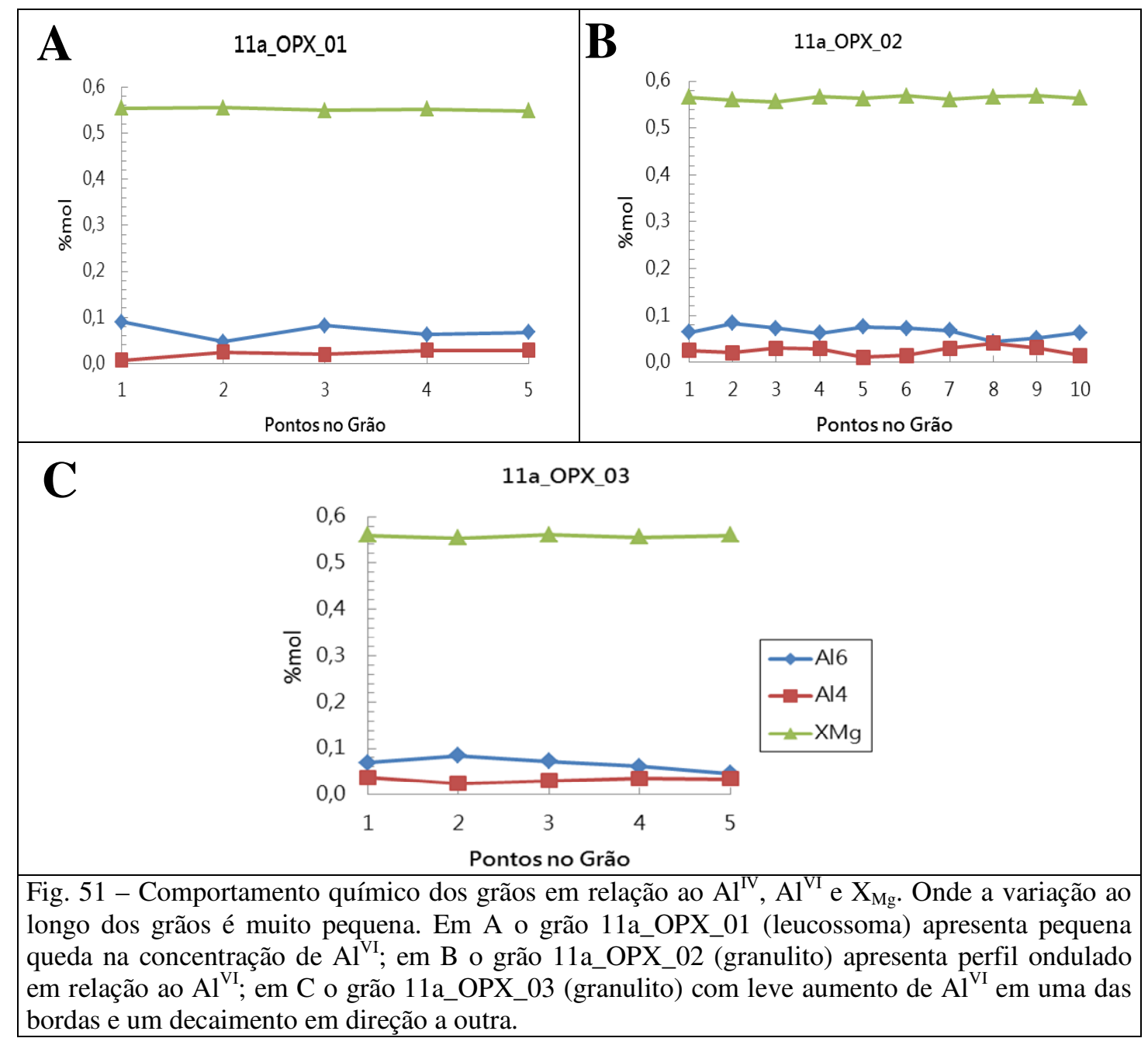




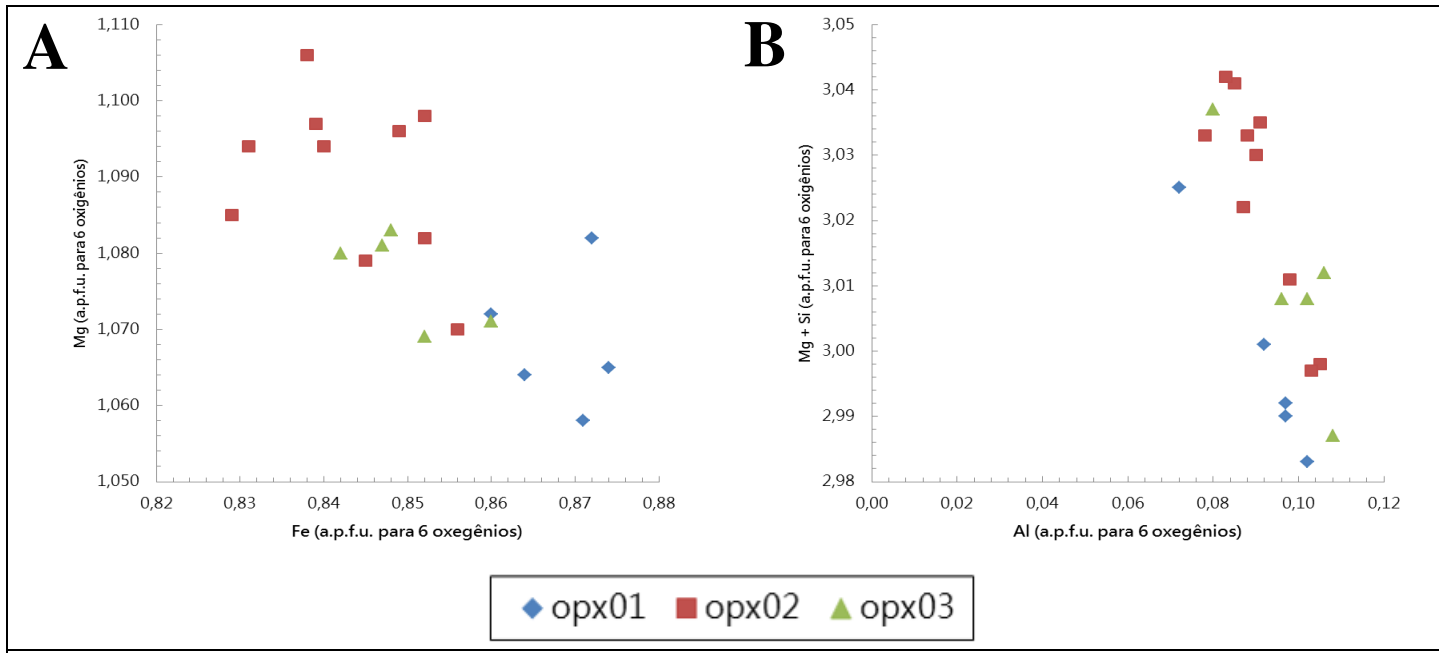

Fig. 52 - Em A substituição $\mathrm{FeMg}_{-1}$ e em B substituições tschermak. Observa-se em a que os grãos plotam em porções diferentes dos gráficos, sendo o leucossoma mais pobre em magnésio e o granulito mais pobre em ferro.

ALFE45Ib é amostra do contado do granada granulito máfico com o hornblenda granulito félsico, separados por leucossoma com porfiroblastos de ortopiroxênio. Foram analisados seis grãos, sendo os três primeiros do granada granulito máfico, o terceiro do leucossoma, entre as duas rochas, e o dois últimos são na interface do leucossoma com o granada granulito máfico. Todos os grãos analisados tiveram pequenas variações químicas muito sutis de alumínio e $\mathrm{X}_{\mathrm{Mg}}$ em relação bordas para os centros dos grãos (Fig. 53). Os grãos analisados no granulito (45Ib_OPX_01, 45Ib_OPX_02, 45Ib_OPX_03) são xenoblásticos e estão intersticiais as de granada, que predominam na maior parte da rocha, apresentam contatos e bordas irregulares e granulação muito fina. O grão analisado no leucossoma (45Ib_OPX_04) é porfiroblástico, subidioblástico, com contatos retos e lobados e alongados segundo a foliação principal, em uma das bordas apresenta-se substituídas por clinopiroxênio e hornblenda. Os grãos da interface (45Ib_OPX_05 e 45Ib_OPX_06) são semelhantes aos da matriz, xenoblásticos, com formas e contatos irregulares e de granulação fina. Todos os perfis são praticamente planos com $\mathrm{X}_{\mathrm{Mg}}$ variando de 0,517 a 0,538 . 


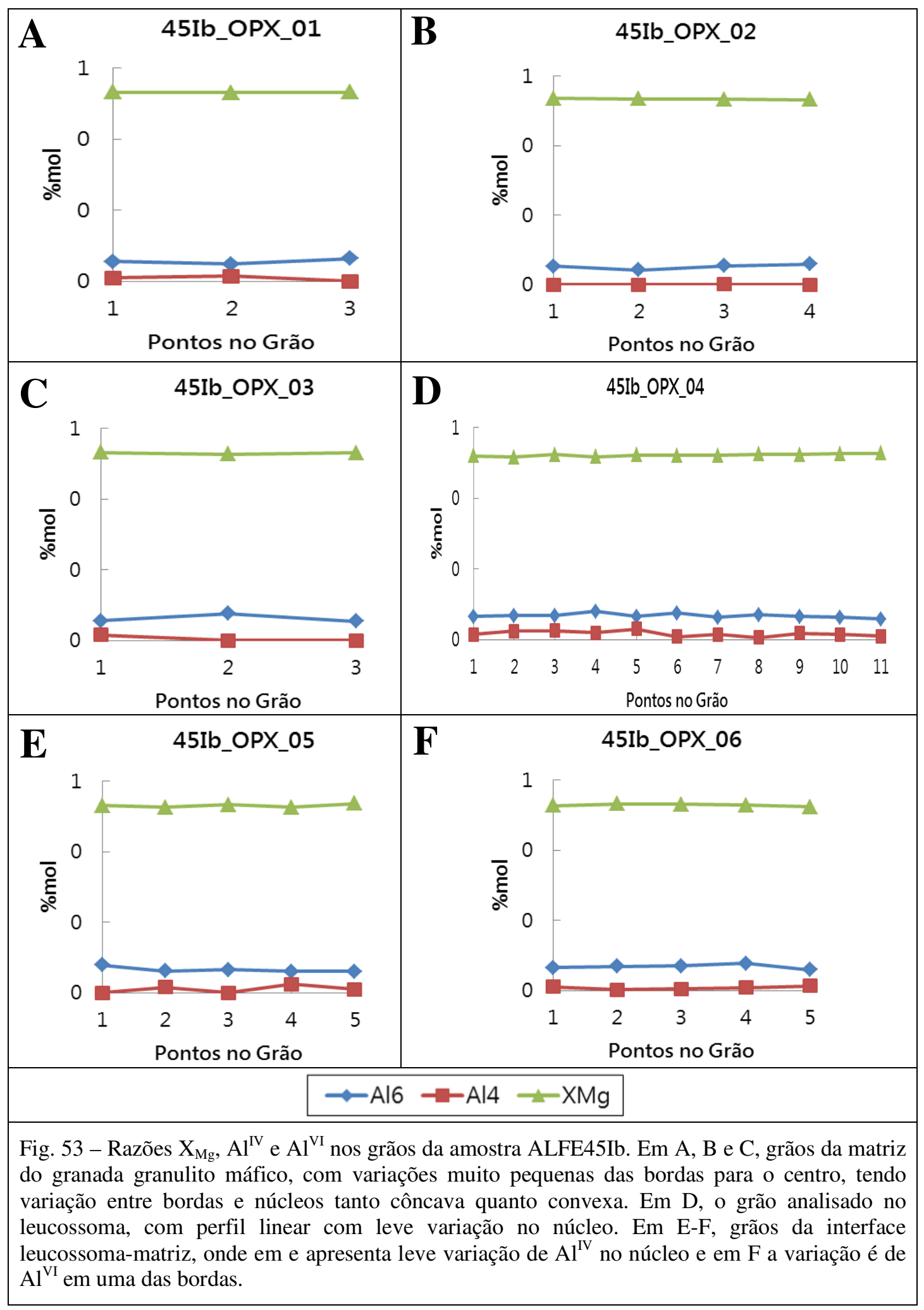


Percebe-se que a variação da quantidade de ferro entre os grãos analisados é quase nula, mas a variação de magnésio é acompanhada de modo inverso pelo alumínio indicando a ação da à substituição Tschemak (Fig. 54 A). O grão do leucossoma é o mais rico em alumínio e os da interface têm composição intermediária com os do granulito, que são os mais pobres em alumínio e os mais ricos em magnésio (Fig. 54B).

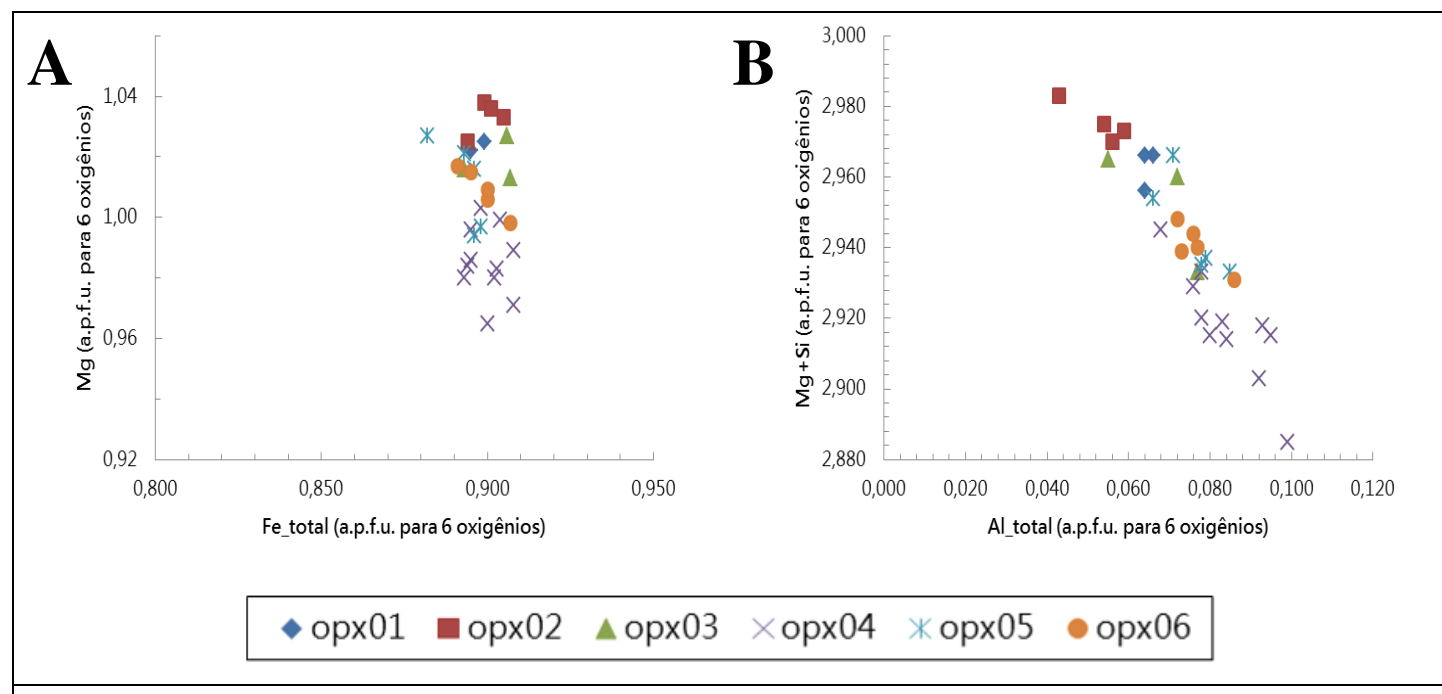

Fig. 54 - Em A, substituição $\mathrm{FeMg}_{-1}$; em $\mathrm{B}$, substituições tschermak. O ferro se mantém constante, o alumínio aumenta e o magnésio diminui da matriz para o leucossoma.

A amostra ALFE45N é de granulito félsico cortado por veio de leucossoma com porfiroblastos de piroxênio. Foram analisados seis grãos, tanto no granulito como no leucossoma, e em ambas as partes os grãos apresentam leve alteração ou encontram-se substituídos por hornblenda. Os grãos da matriz são subidioblásticos a xenoblásticos, com contatos irregulares e granulação muito fina, geralmente associados a hornblenda. No leucossoma são porfiroblasto, com formas e contatos suaves a levemente irregulares, apresentam fraturas e bordas substituídas por hornblenda e estão alongados segundo foliação principal. A razão $\mathrm{X}_{\mathrm{Mg}}$ apresenta perfil plano e homogêneo ao longo dos grãos, mas as proporções de alumínio variam levemente da borda para o centro, sendo $\mathrm{Al}^{\mathrm{IV}}$ inversamente proporcional ao $\mathrm{Al}^{\mathrm{VI}}$ (Fig. 55). 


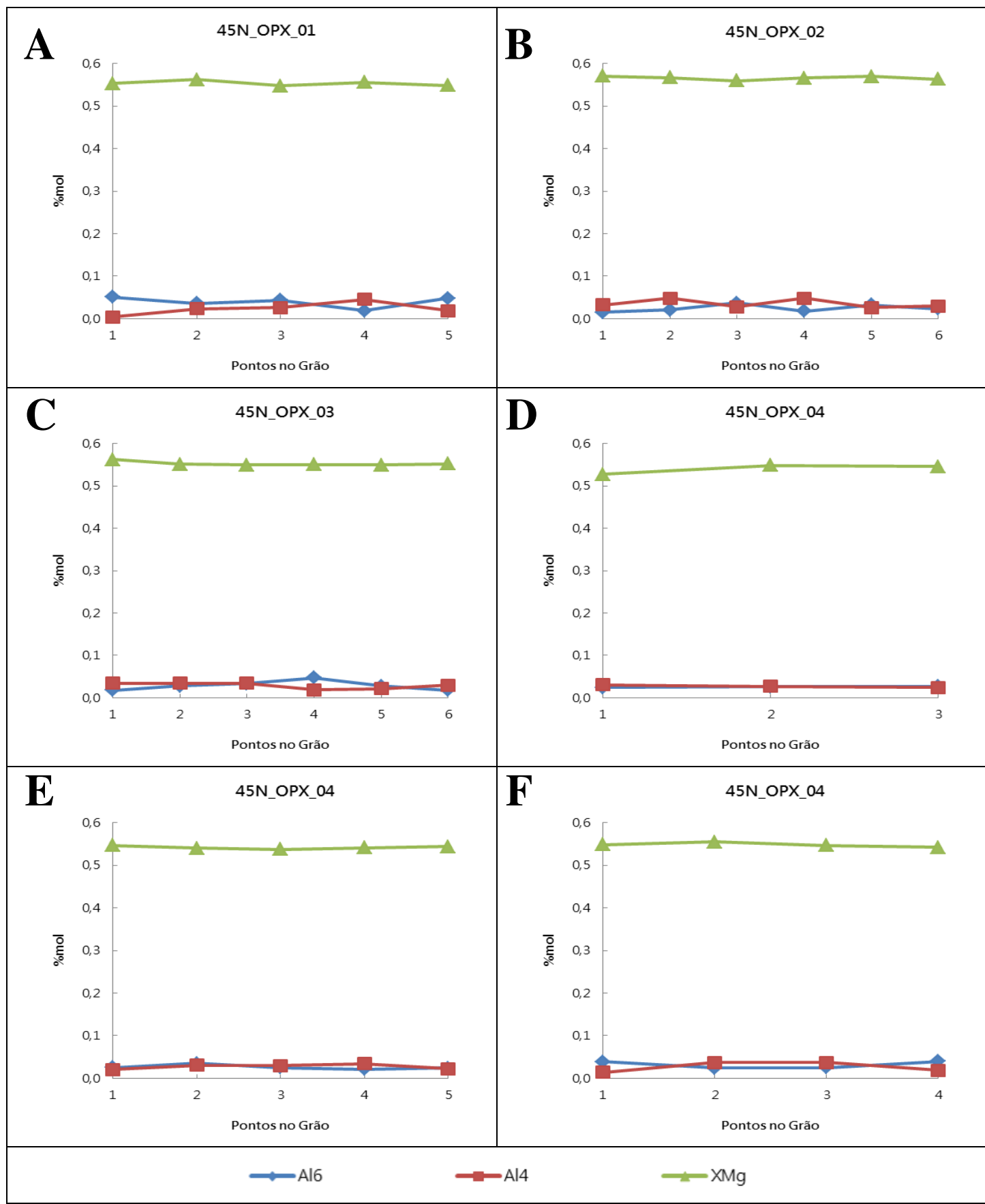

Fig. 55 - Razão $\mathrm{X}_{\mathrm{Mg}}$ e proporções $\mathrm{Al}^{\mathrm{VV}}$ e $\mathrm{Al}^{\mathrm{VI}}$ em todos os grãos. Em A, B, C são os grãos analisados no leucossoma, tendo o $\mathrm{Al}^{\mathrm{VI}}$ variando mais nos núcleos que nas bordas. Em D, E, F, são os grãos analisados na matriz que apresentam mais regularidade em relação as proporções de alumínio ao longo dos grãos. 
Os grãos do leucossoma (45N_OPX_01, 45N_OPX_02 e 45N_OPX_03) apresentam maiores concentrações de magnésio em relação aos do granulito (45N_opx_04, 45N_OPX_05 e 45N_OPX_06), entretanto as concentrações de ferro e alumínio apresentam menor variação entre leucossoma e granulito (Fig. 56).

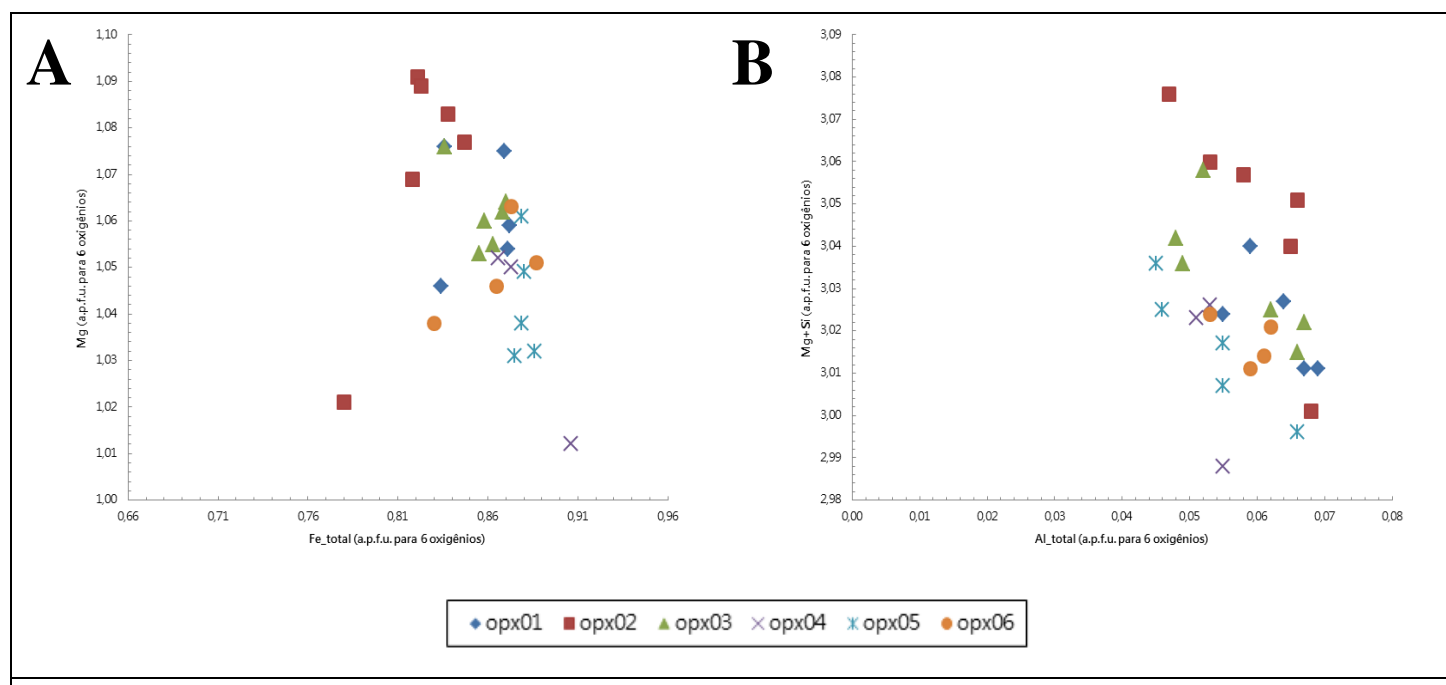

Fig. 56 - A) Substituição FeMg-1 e B) substituições tschermak. Não há muitas variações de ferro e alumínio na rocha, porem a quantidade de magnésio diminui do leucossoma em relação a matriz.

A amostra ALFE45V1 é de granada granulito com veios de leucossoma paralelo ao bandamento contendo porfiroblastos de ortopiroxênio e granada. Foram analisados seis grãos, dois no leucossoma (45V1_OPX_01 e 45V1_OPX_02), um na interface do leucossoma com o granulito (45V1_OPX_03) e outros dois no granada granulito (45V1_OPX_04 e 45V1_OPX_05). Os porfiroblastos do leucossoma (até 1,0 cm) variam de idioblásticos a xenoblásticos, com bordas corroídas e irregulares e com fraturas alteradas. O grão da interface é mais límpido, um pouco menor que os do leucossoma $(<0,5 \mathrm{~mm})$, xenoblásticos, com bordas irregulares, e os grãos do granulito são xenoblásticos, alongados segundo a foliação principal, de granulação muito fina, contornos irregulares e muito fraturados, geralmente associados à hornblenda. As razões $\mathrm{X}_{\mathrm{Mg}}$ e a concentração de alumínio são regulares ao longo dos grãos com variações mais expressivas em alumínio nos grãos do leucossoma, onde um apresenta maiores concentrações de $\mathrm{Al}^{\mathrm{VI}}$ no núcleo e o outro as concentrações de $\mathrm{Al}^{\mathrm{IV}}$ são maiores que as de $\mathrm{Al}^{\mathrm{VI}}$ nas bordas. Em um dos grãos da matriz as proporções de $\mathrm{Al}^{\mathrm{IV}}$ são maiores que as de $\mathrm{Al}^{\mathrm{VI}}$ (Fig. 57). 


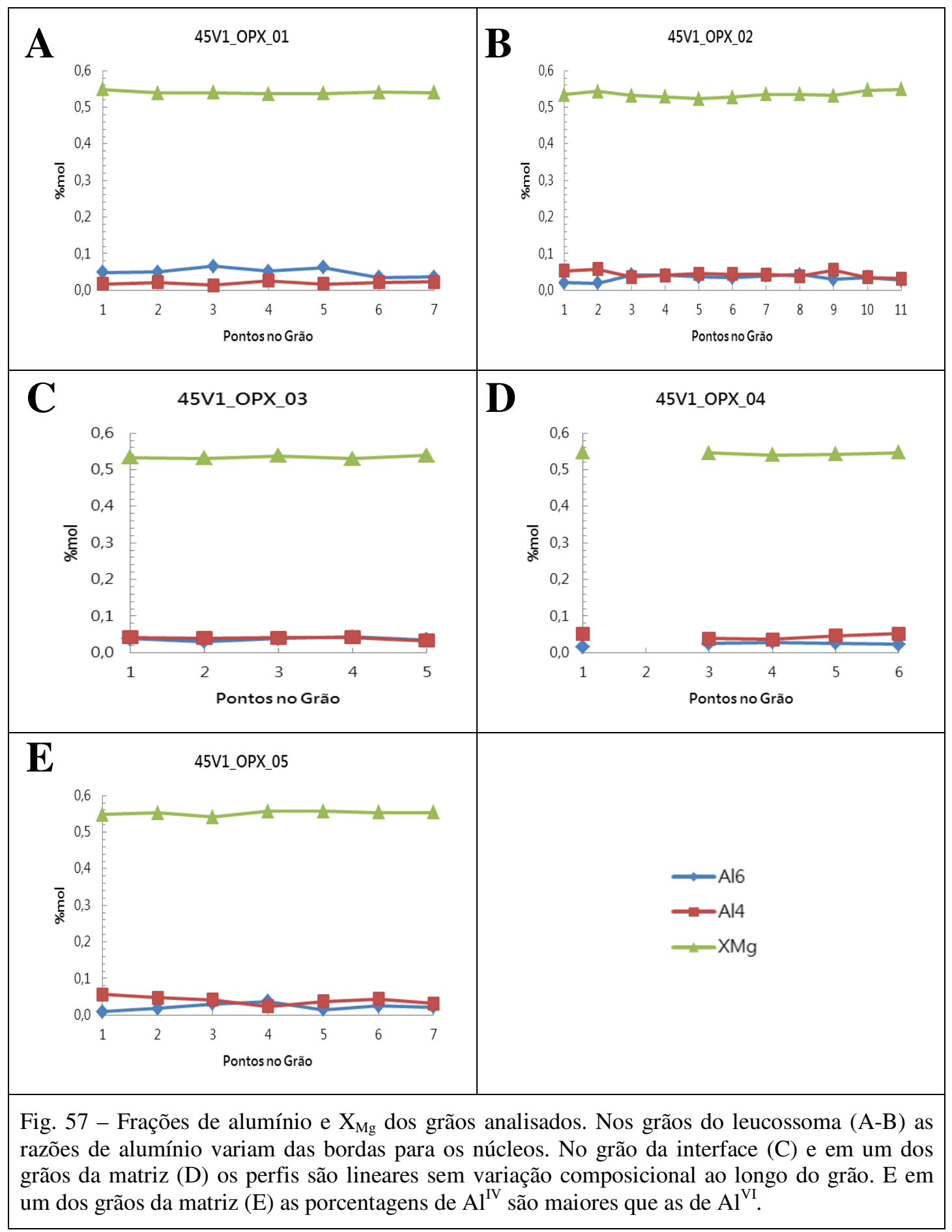


As trocas entre magnésio-ferro e magnésio-alumínio (Tschemak) indicam que os grãos do granulito são mais ricos em magnésio que os do leucossoma, formando um perfil decrescente tanto em relação ao ferro quanto ao alumínio. A variação de ferro e alumínio não é muito expressiva, mas é possível diferenciar que no leucossoma os grãos são mais ricos em ferro e alumínio, principalmente nesse último, do que o do granulito (Fig. 58).

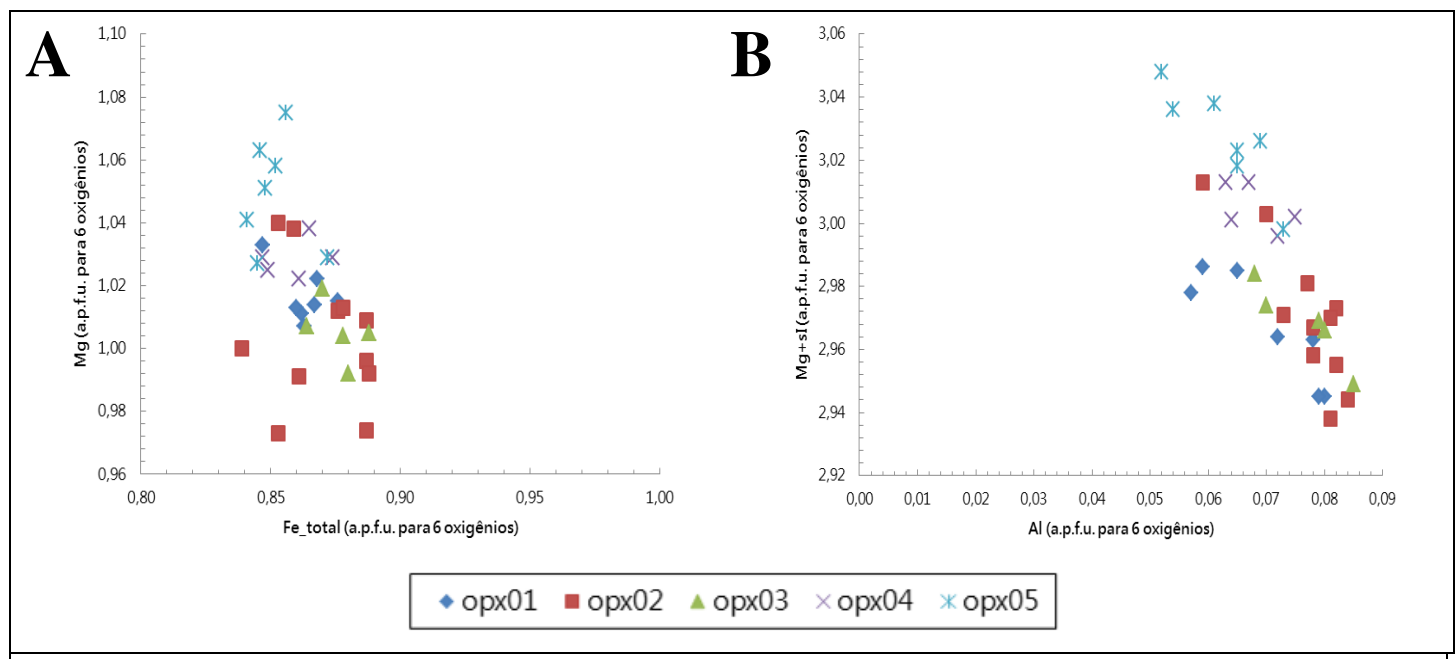

Fig. 58 - Relação $\mathrm{FeMg}_{-1}$ e $\mathrm{Al}_{\text {total }} \mathrm{Mg}_{-1}$ (Tschermak), onde o leucossoma (opx01 e opx02) apresenta-se mais rico em magnésio e mais pobre em ferro e alumínio.

\subsubsection{Clinopiroxênio}

O clinopiroxênio é classificado de acordo com a ocupação do sítio M2 por cálcio ou sódio e também ocorrem trocas catiônicas do tipo Tschermak. A amostra selecionada para análise foi a ALFE45N que apresenta clinopiroxênio em equilíbrio com ortopiroxênio. Foram analisados quatro grãos, dois no leucossoma (45N_CPX_01 e 45N_CPX_02) e dois no granulito félsico (45N_CPX_03 e 45N_CPX_04). Tanto os grãos do granulito félsico quanto do leucossoma são subidioblásticos, alongados segundo a foliação principal, com contatos e bordas irregulares. Os grãos do granulito são menores e apresentam as bordas substituídas por hornblenda e os grãos do leucossoma são porfiroblásticos $(0,5 \mathrm{~mm})$ e apresentam-se mais límpidos em relação aos do granulito. A composição do clinopiroxênio não apresenta muitas diferenças entre os grãos do leucossoma e do granulito e as variações de alumínio e $\mathrm{X}_{\mathrm{Mg}}$ ao longo dos grãos são sutis, com valores de $\mathrm{X}_{\mathrm{Mg}}$ variando entre a 0,6 e 0,6 (Fig. 59). Nos gráficos de vetores de troca 
é possível observar pequeno aumento de alumínio e ferro dos grãos do leucossoma em relação aos do granulito (Fig. 60).

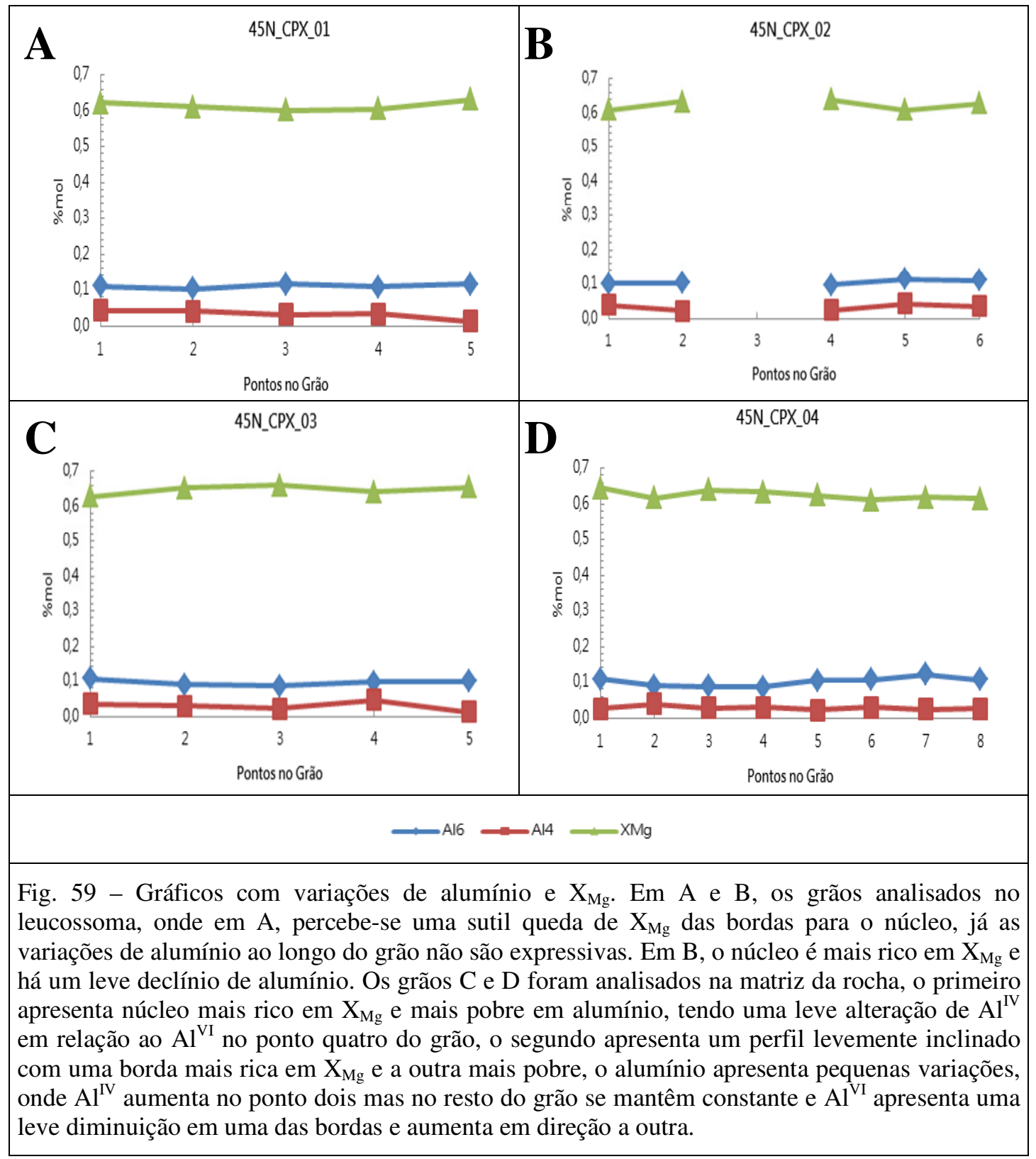




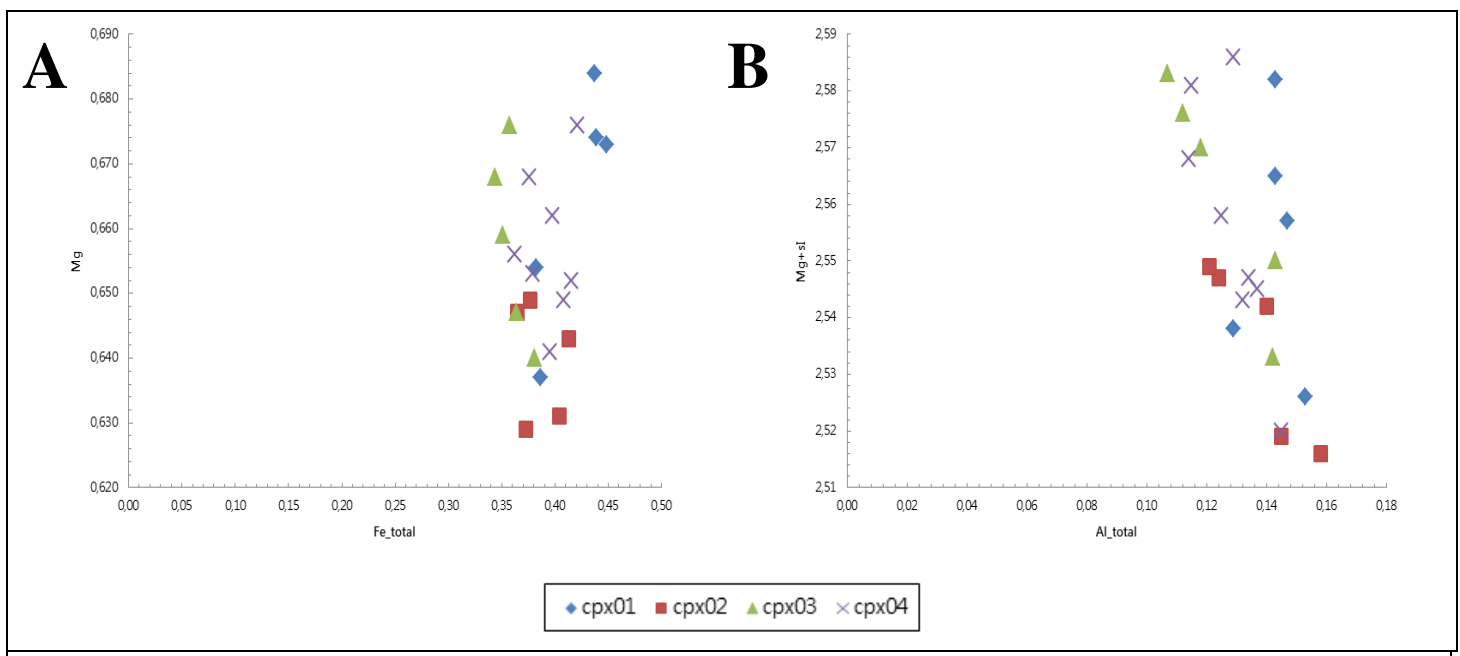

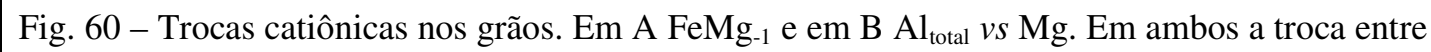
os elementos é sutil, a medida que a rocha perde magnésio ela enriquece levemente em alumínio.

\subsection{Feldspatos}

Feldspatos são minerais importantes em cálculos de pressão e sua composição é sensível as mudanças de temperatura do metamorfismo, sendo um grupo importante para os cálculos $P$ - $T$ do metamorfismo. A fórmula estrutural dos feldspatos é: $\mathrm{MT}_{4} \mathrm{O}_{8}$, sendo que quando $\mathrm{M}$ é ocupado por $\mathrm{K}$ e $\mathrm{Na}$, o sítio $\mathrm{T}$ é ocupado por $\mathrm{Al}+3 \mathrm{Si}$, mas se $\mathrm{M}$ é ocupado por $\mathrm{Ca}, \mathrm{T}$ é preenchido por $2 \mathrm{Al}+2 \mathrm{Si}$. Duas soluções sólidas binárias dividem a composição do grupo dos feldspatos, tendo como membros finais albita e feldspato potássico $\left(\mathrm{NaAlSi}_{3} \mathrm{O}_{8}-\mathrm{KAlSi}_{3} \mathrm{O}_{8}\right)$, e do plagioclásio com albita e anortita $\left(\mathrm{NaAlSiO}_{8}-\right.$ $\left.\mathrm{CaAl}_{2} \mathrm{Si}_{2} \mathrm{O}_{8}\right)$ como membros finais. Só em temperaturas muito elevadas é possível observar a mistura dos três membros finais, mas de forma limitada. Para as variações composicionais é necessário ocorrer as substituições $\mathrm{KNa}_{-1}$ e $\mathrm{NaSiCa}_{-1} \mathrm{Al}_{-1}$. Para o cálculo dos membros finais foram usadas as fórmulas:

$\operatorname{Anortita}(\mathrm{An})=(\mathrm{Ca} /(\mathrm{Ca}+\mathrm{Na}+\mathrm{K})) * 100$

Albita $(\mathrm{Ab})=(\mathrm{Na} /(\mathrm{Ca}+\mathrm{Na}+\mathrm{K})) * 100$

Ortoclásio $(\mathrm{Or})=(\mathrm{K} /(\mathrm{Ca}+\mathrm{Na}+\mathrm{K})) * 100$ 
As rochas estudadas apresentam os dois feldspatos. Para as rochas do Complexo Campos Gerais foram analisados plagioclásio e feldspato alcalino, porém, apenas plagioclásio para as rochas da Nappe Socorro-Guaxupé.

\subsubsection{Plagioclásio}

Foram analisados grãos de plagioclásio de uma amostra do Complexo Campos Gerais (ALFE24b) e de cinco da Nappe Socorro-Guaxupé, onde três amostras são da Unidade Granulítica (ALFE11a, ALFE45i e ALFE45v1) e duas da Unidade Diatexítica (ALFE71c e ALFE71e1). Na amostra do Complexo Campos Gerais foram analisados cinco grãos na matriz. Os grãos apresentam composição $A n_{4,6-12,0} \mathrm{Ab}_{87,5-95,1} \mathrm{Or}_{0,1-3,8}$, geralmente com o núcleo dos grãos mais pobre em $\mathrm{Ca}$, com exceção do primeiro grão (24b_plg_01) que apresenta o núcleo mais rico em Ca (Fig. 61).

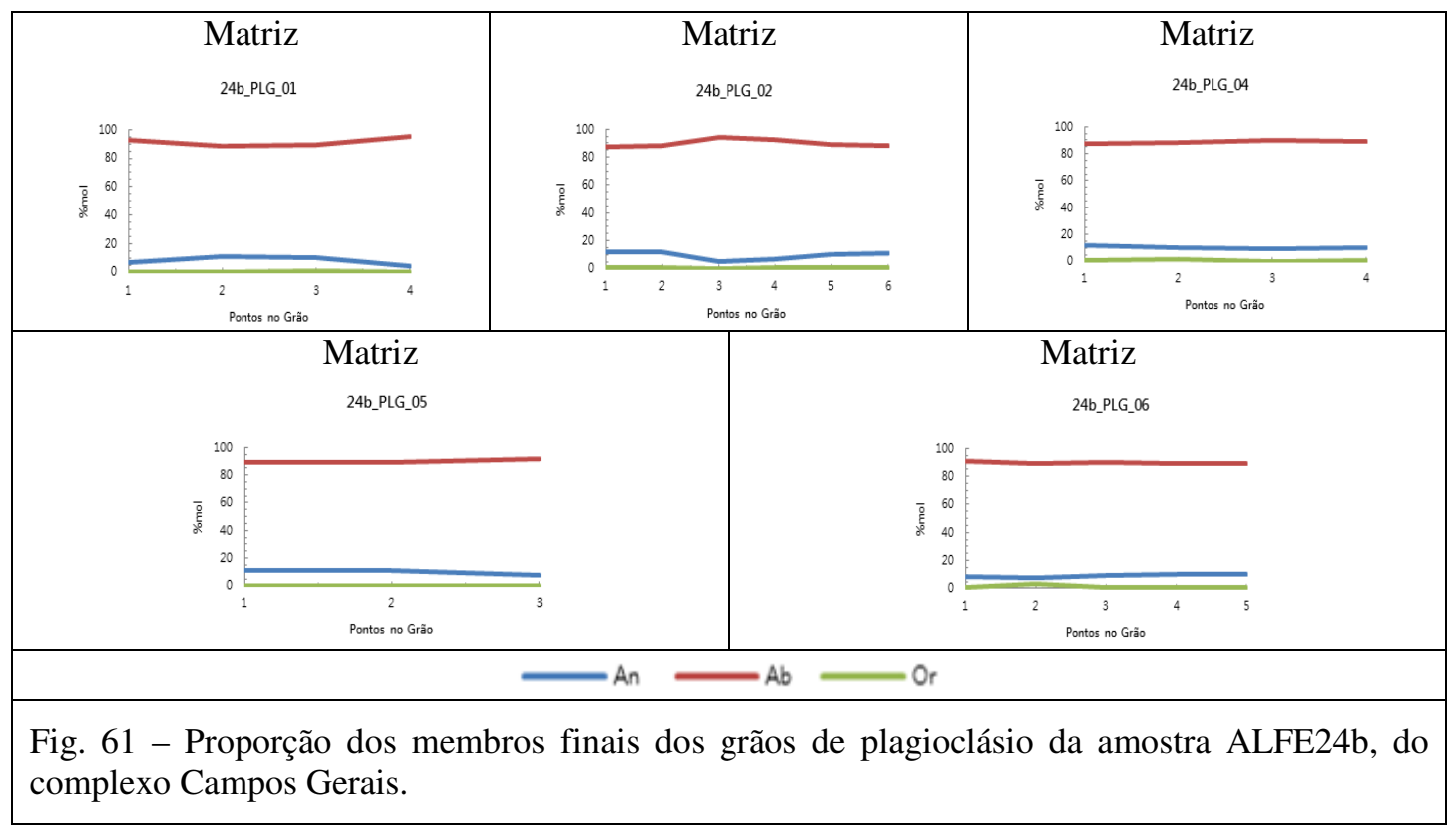

As amostras da unidade granulítica são ALFE11a, ALFE45I e ALFE45N. Ao todo foram analisados vinte grãos, sendo nove no leucossoma e onze em granulitos. Na amostra ALFE11a a composição dos grãos do leucossoma é $\mathrm{An}_{28,0-30,2} \mathrm{Ab}_{67,8-69,4} \mathrm{Or}_{1,8-2,8}$, com Ca crescente em uma das bordas, e no granulito félsico $\mathrm{An}_{28,1-31,1} \mathrm{Ab}_{65,4-68,6} \mathrm{Or}_{1,6-5,4}$, com teor de Ca menor no núcleo dos grãos (Fig. 62). 


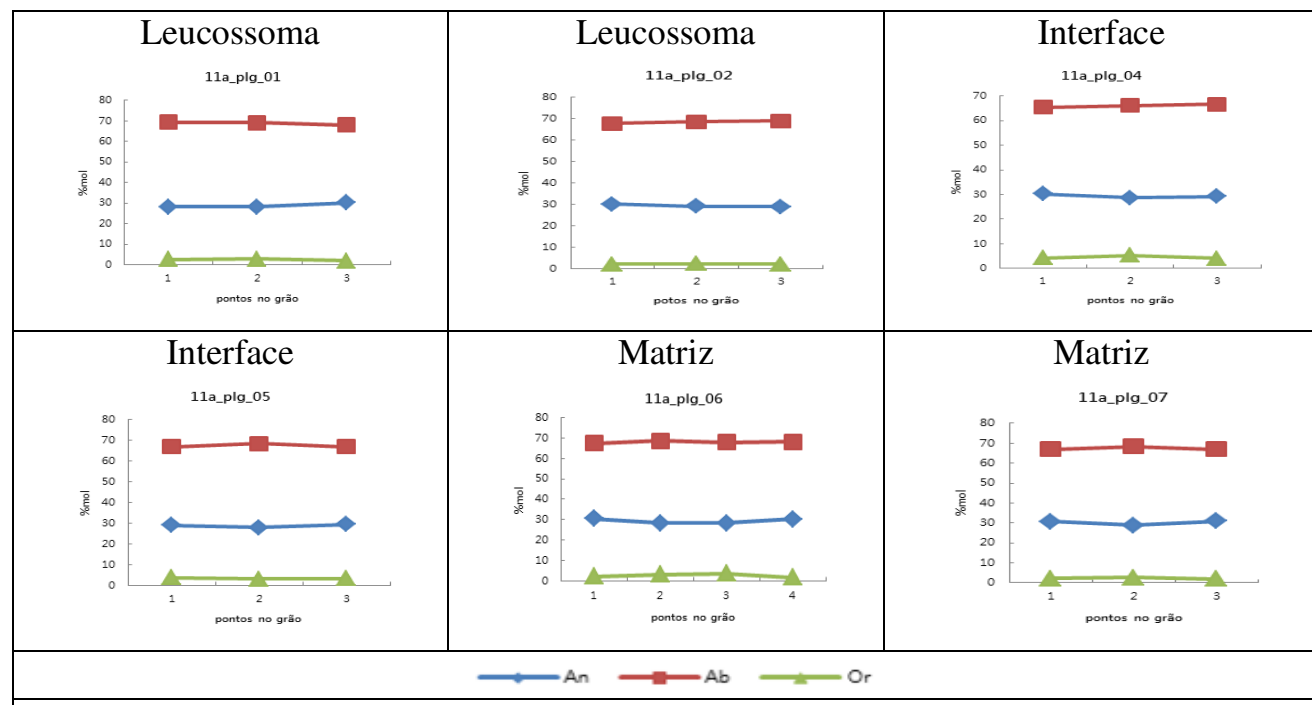

Fig. 62 - Proporção dos membros finais dos grãos de plagioclásio da amostra ALFE11a.

$\mathrm{Na}$ amostra ALFE45I os grãos do leucossoma apresentam composição $\mathrm{An}_{27,5-}$ ${ }_{32,5} \mathrm{Ab}_{65,1-71,4} \mathrm{Or}_{1,1-2,9}$, com diminuição de $\mathrm{Ca}$ de uma borda para outra nos dois grãos, e os do granulito apresentam composição $\mathrm{An}_{29,8-32,6} \mathrm{Ab}_{65,5-68,2} \mathrm{Or}_{1,2-3,4}$, a qual não varia muito ao longo dos grãos deixando os perfis planos (Fig. 63).

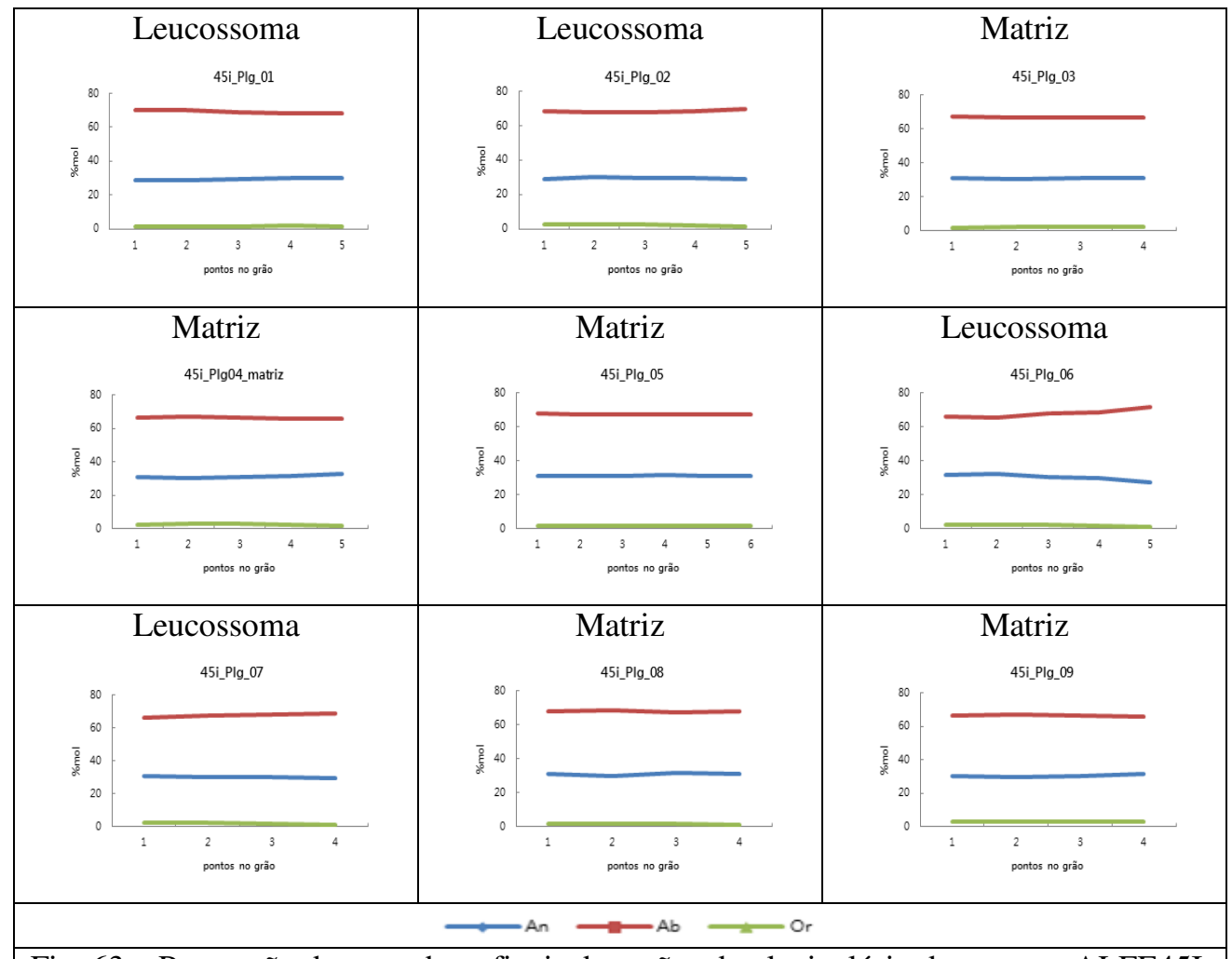

Fig. 63 - Proporção dos membros finais dos grãos de plagioclásio da amostra ALFE45I. 
A composição dos grãos do leucossoma da amostra ALFE45N é $A_{26,7-28,3} A_{6} b_{69,7-}$ 71,4 $\mathrm{Or}_{1,1-2,1}$ e os do granulito é $\mathrm{An}_{27,3-28,8} \mathrm{Ab}_{68,4-70,194} \mathrm{Or}_{1,6-2,9}$. Não há variações expressivas ao longo dos grãos tanto na matriz como no leucossoma, a diferença entre os dois está na proporção de anortita, que é um pouco maior na matriz (Fig. 64).

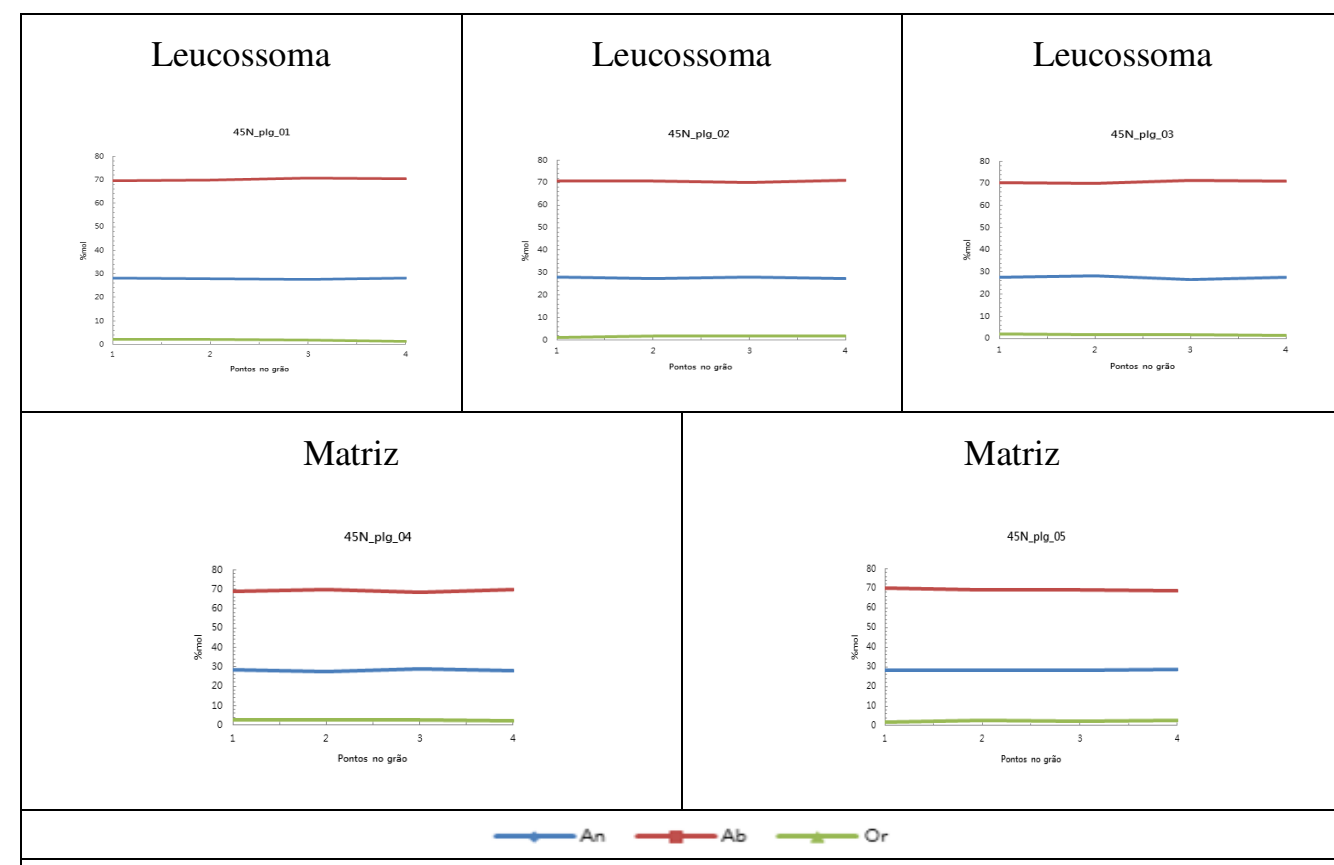

Fig. 64 - Proporção dos membros finais dos grãos de plagioclásio da amostra ALFE45N.

As rochas da unidade diatexítica são representadas pelas amostras ALFE71c (leucossoma) e ALFE71e1 (matriz). Ao todo foram analisados oito grãos, três no leucossoma e cinco na mesossoma. Os grãos do leucossoma apresentam $\mathrm{An}_{20,3-29,0} \mathrm{Ab}_{68,4-}$ ${ }_{77,4} \mathrm{Or}_{1,0-6,4}$, todos com teores de Ca mais elevados no núcleo e os grãos do mesossoma apresentam composição $\mathrm{An}_{31,4-35,0} \mathrm{Ab}_{61,8-65,1} \mathrm{Or}_{22,0-3,8}$ com comportamento quimicamente homogêneo ao longo dos grãos. Os grãos do mesossoma apresentam muito mais Ca que os do leucossoma (Fig. 65). 


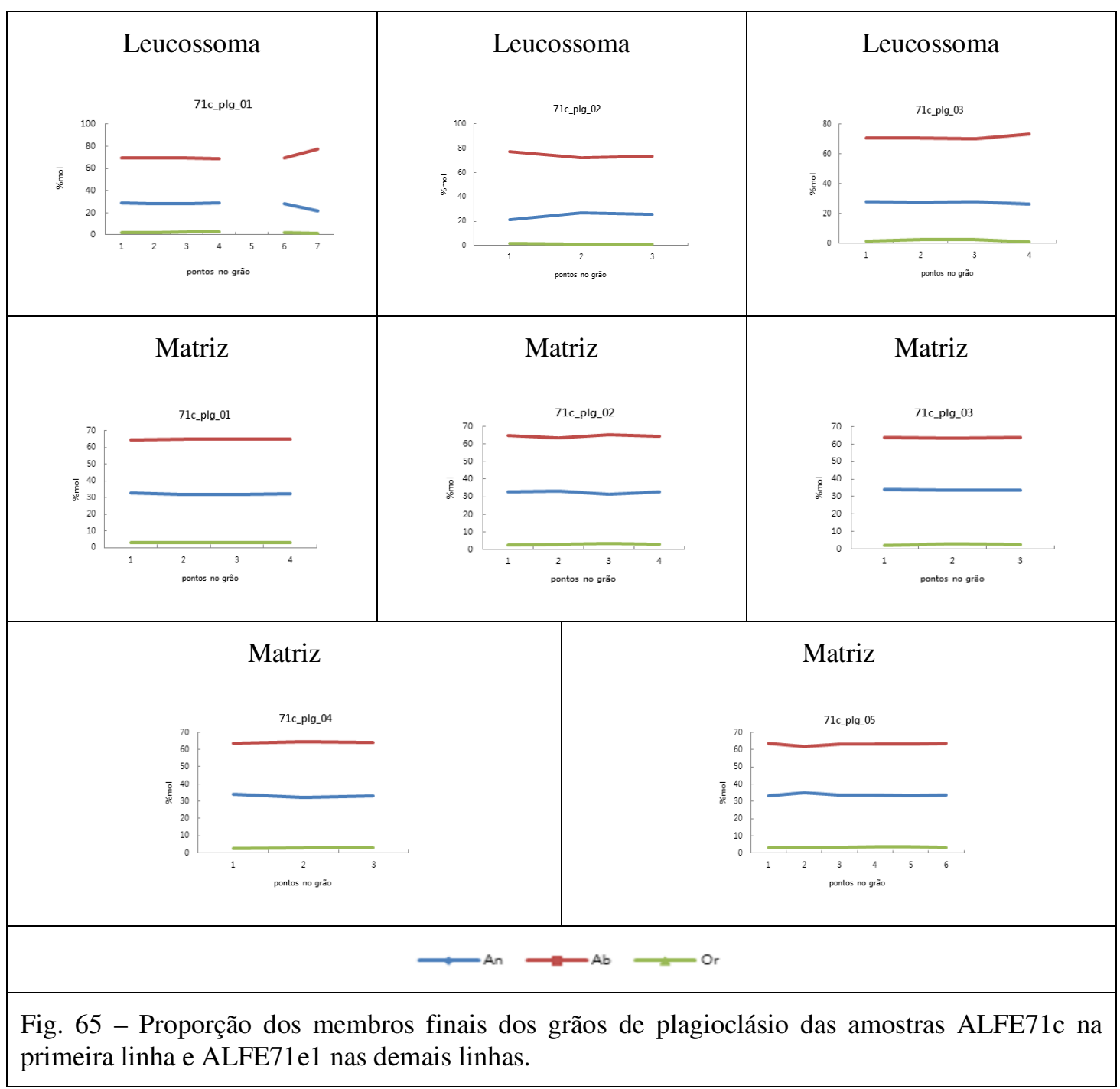

\subsubsection{Feldspato Potássico}

Apenas uma amostra foi selecionada para feldspato potássico, a ALFE24b. Foram analisados cinco grãos e sua composição é: $\mathrm{An}_{9,9-10,8} \mathrm{Ab}_{2,0-5,9} \mathrm{Or}_{83,9-88,1}$, com bordas mais ricas em $\mathrm{K}$ na maioria dos grãos e com presença de leve aumento em Na no núcleo dos grãos (Fig. 66). A irregularidade do conteúdo de $\mathrm{Na}$ e Ca está ligado ao fato de que é muito difícil obter análises sem influência das lamelas de exsolução que ocorrem em escala sub-microscópica. 


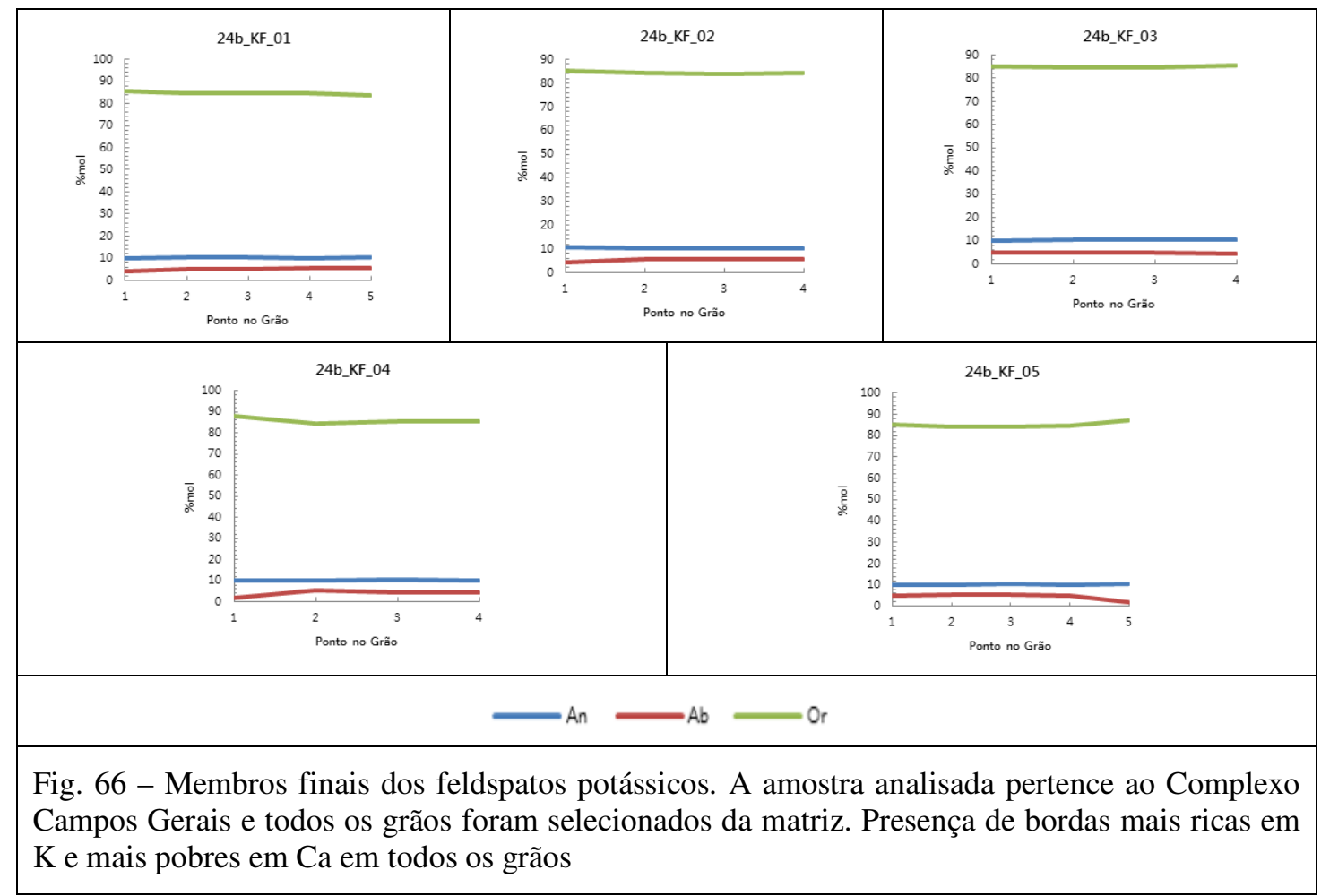

\subsection{Anfibólio}

O anfibólio é um grupo de minerais com importância similar ao grupo dos piroxênios e ocorre em diversos tipos de rochas ígneas e principalmente nas rochas metamórficas de temperatura média a alta. A formula geral é representada por: $\mathrm{X}_{2^{-}}$ ${ }_{3} \mathrm{Y}_{5} \mathrm{Z}_{8} \mathrm{O}_{22}(\mathrm{OH})_{2}$, onde a posição A é ocupada por cátions grandes (com cerca de 1,3A de raio), em coordenação 12 com o oxigênio dos vértices dos tetraedros, representados principalmente por $\mathrm{K}, \mathrm{Ba}$ e $\mathrm{Rb}$; a posição $\mathrm{X}$ é ocupada por cátions grandes (cerca de $1 \mathrm{~A}^{\mathrm{o}}$ de raio), em coordenação 8 com o oxigênio dos vértices cúbicos, representados principalmente por $\mathrm{Ca}$, $\mathrm{Na}$ e mais raramente o $\mathrm{K}$; a posição $\mathrm{Y}$ é ocupada por cátions com dimensões de raios iônicos ao redor de 0,7A como $\mathrm{Mg}, \mathrm{Fe}^{2+}, \mathrm{Fe}^{3+}, \mathrm{Al}, \mathrm{Mn}, \mathrm{Ti}, \mathrm{Li}, \mathrm{Mn}^{3+}$, Cr, etc., resultando em coordenação 6 (octaédrica) com o oxigênio; a posição Z, é ocupada por cátions pequenos em coordenação tetraédrica com o oxigênio gerando o radical da estruturação dos silicatos; "m", "n" e "o" correspondem ao número de elementos na formula química. A classificação dos anfibólios pode ser baseada na 
composição química ou cristaloquímica, em propriedades óticas e outras propriedades determinativas (Garda, G.M., Atencio, D., 1991).

Quando a fórmula padrão do anfibólio estiver determinada, este é primeiramente classificado entre um dos quatro grupos principais de anfibólios com base no número de átomos de $(\mathrm{Ca}+\mathrm{Na})_{\mathrm{B}}$ e $\mathrm{Na}_{\mathrm{B}}$. Esses grupos são (Leake, 1997):

(1) $\mathrm{Se}(\mathrm{Ca}+\mathrm{Na})_{B}<1.00$ e a soma dos íons $(\mathrm{Mg}, \mathrm{Fe}, \mathrm{Mn}, \mathrm{Li})_{B} \geq 1.00$, então serão do grupo dos anfibólios $\mathrm{Mg}-\mathrm{Fe}-\mathrm{Mg}-\mathrm{Li}$;

(2) $\mathrm{Se}(\mathrm{Ca}+\mathrm{Na})_{B} \geq 1.00$ e $\mathrm{Na}_{B}<0.50$, então serão do grupo dos anfibólios cálcicos.

(3) $\mathrm{Se}(\mathrm{Ca}+\mathrm{Na})_{B} \geq 1.00$ e $\mathrm{Na}_{B}$ esta no interval entre 0.50 a 1.50 , então serão do grupo dos anfibólios de $\mathrm{Na}-\mathrm{Ca}$.

(4) $\mathrm{Se} N a_{B} \geq 1.50$, então serão do grupo dos anfibólios Sódicos.

Dentro de um destes grupos o anfibólio poderá ser então nomeado por meio do diagrama bidimensional apropriado, utilizando-se o número de átomos de $\mathrm{Si}$ e a razão $\mathrm{Mg} /\left(\mathrm{Mg}+\mathrm{Fe}^{2+}\right)$ poderão ser classificados.

Os anfibólios das rochas da região estudada apresentaram composições químicas (ANEXO 2) que se encaixam nas condições propostas por Leake (1997) onde $(\mathrm{Ca}+\mathrm{Na})_{B}$ $\geq 1.00$ e $N a_{B}<0.50$ (Fig. 67), sendo assim os anfibólios são do grupo dos anfibólios cálcicos, mais especificamente a Ferropargasita.

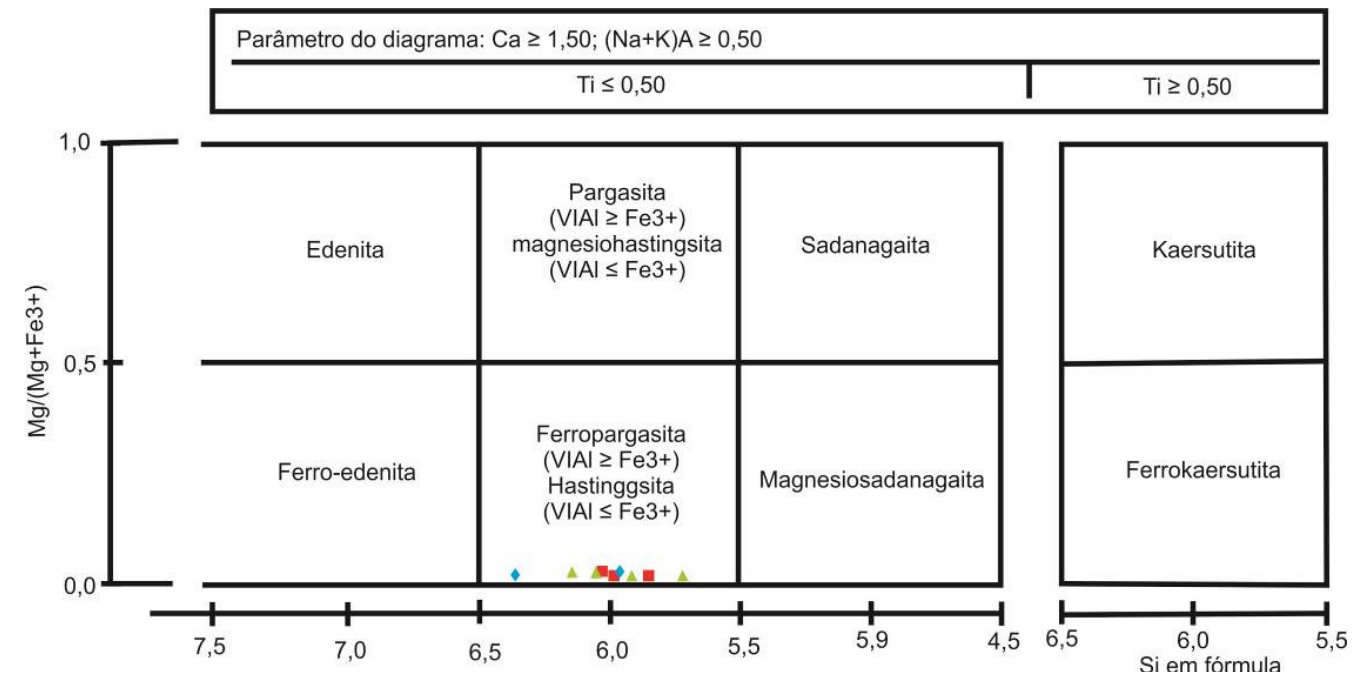

Fig. 67 - Gráfico de classificação dos Anfibólios Cálcicos. O pontos coloridos indicam aproximadamente a composição dos anfibólios das rochas da região. 
Com a análise das rochas ficou evidente que, devido ao intenso metamorfismo das rochas e a influência de água no sistema, o anfibólio da Nappe Socorro-Guaxupé não é adequado para análise, pois há muita variação de composição entre os grãos de anfibólio. Assim todas as análises são de rochas do Complexo Campos Gerais. A amostra selecionada para análise foi ALFE24b e nela foram selecionados três grãos (24b_hbl_01, 24b_hbl_02 e 24b_hbl_03). Os grãos são xenoblásticos com contornos e bordas regulares.

Em relação às trocas catiônicas, não há variação expressiva das bordas para o centro dos grãos. O grão 24b_hbl_01 apresenta decréscimo em Ti em uma das bordas e o grão 24b_hbl_02 apresenta o núcleo mais rico em alumínio (Fig. 68).

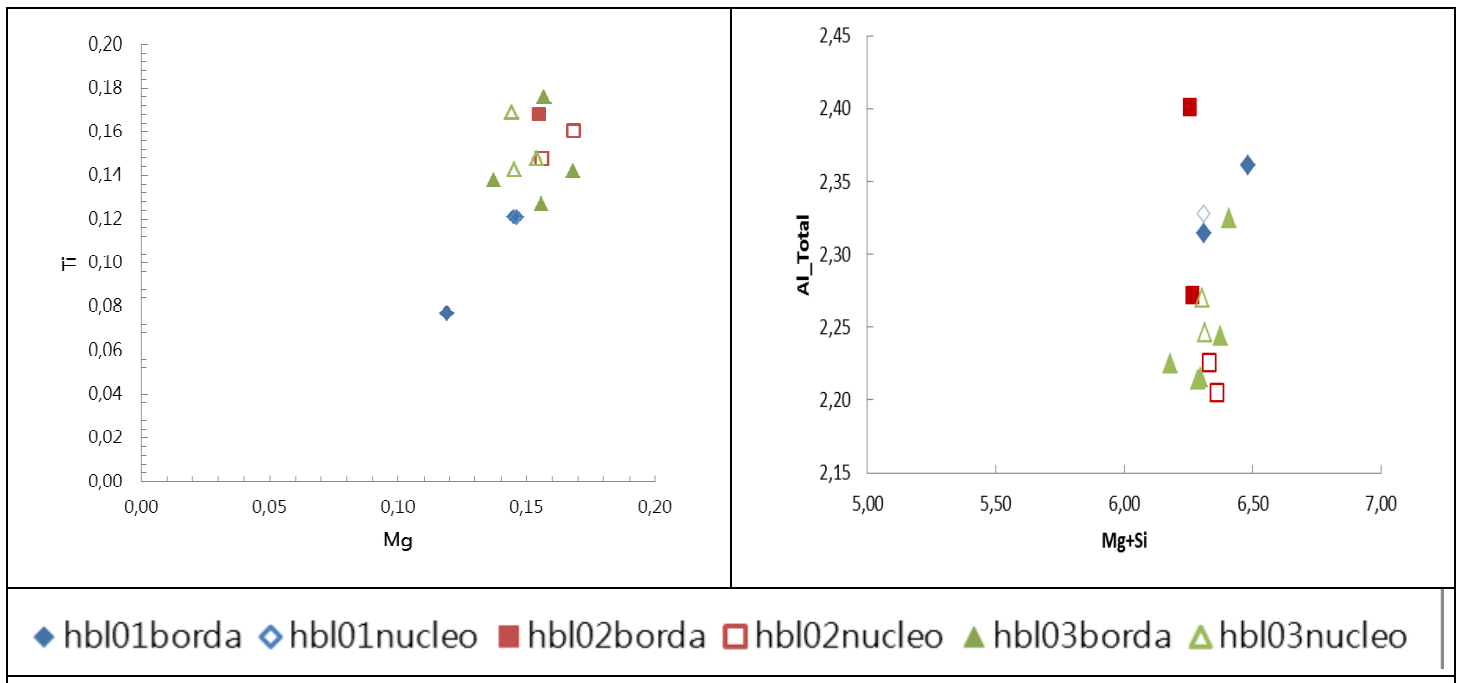

Fig. 68 - Vetores de trocas catiônicas, onde 24b_hbl_01 apresenta uma das bordas mais pobre em Ti e o grão 24b_hbl_02 não apresenta variação de núcleo e borda.

\subsection{Biotita}

A biotita é a mica escura de composição muito variável, podendo ser observada em amplo campo $P-T$ metamórfico. A fórmula estrutural resumida é: $\mathrm{A}(\mathrm{M} 1+\mathrm{M} 2)_{3} \mathrm{~T}_{4} \mathrm{O}_{10}(\mathrm{OH})_{2}$ onde A é ocupado por $\mathrm{K}$ com menor quantidade de $\mathrm{Na}$, os sítios M1 e M2 são ocupados por $\mathrm{Al}, \mathrm{Mg}$ e Fe com Mn, Cr, Ti e Li, e a posição T é ocupada por $\mathrm{Si}$ e $\mathrm{Al}$ e as vezes por $\mathrm{Fe}^{3+}$ e Ti, sendo a proporção $\mathrm{Si}: \mathrm{Al}$ de 6:2. Os grãos analisados são de rochas do Complexo Campos Gerais (ALFE2b) e da Nappe Socorro-Guaxupé, unidade diatexítica (ALFE71c e ALFE71e1). 
Três grãos de biotita foram analisados na matriz da rocha do Complexo Campos Gerais (24b_bt_01,24b_bt_02 e 24b_bt_03). Pode-se observar que os teores de Fe, Ti e Al nos grãos são elevados. Há uma correlação positiva entre $\mathrm{X}_{\mathrm{Mg}}$ com Ti e Fe com $\mathrm{Mg}$ e correlação negativa entre Mg, Si e Ti com Al (Fig. 69).

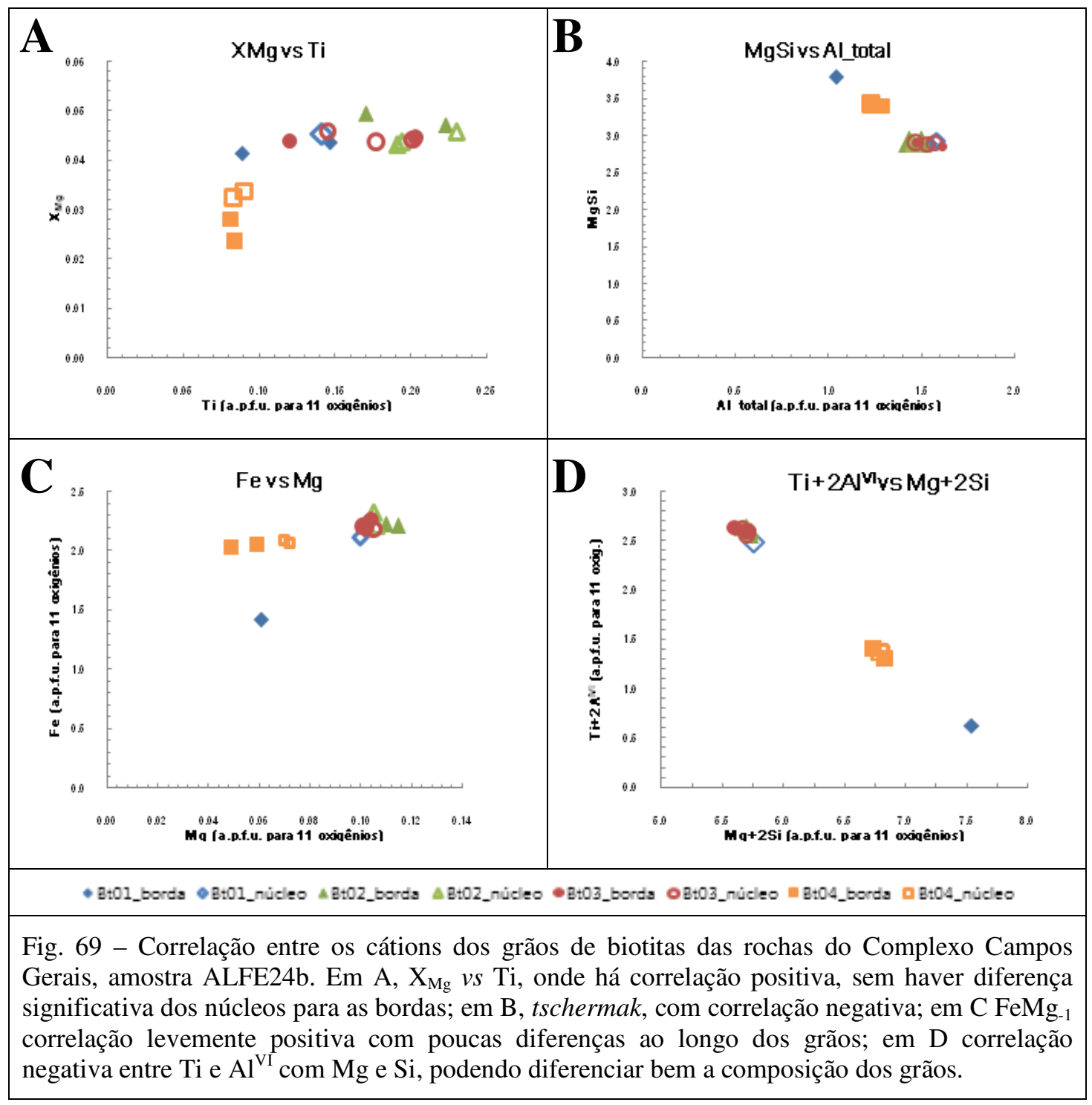

Nas rochas da Nappe Socorro-Guaxupé foram selecionadas duas amostras, na primeira (ALFE71c) foram analisados três grãos no leucossoma da rocha. Todos os grãos analisados são texturalmente estáveis. Pelas análises observa-se que os teores de $\mathrm{Fe}, \mathrm{Mg}$ e $\mathrm{Al}$ são elevados e ocorrem correlações negativas entre $\mathrm{X}_{\mathrm{Mg}}, \mathrm{Mg}$ e $\mathrm{Si}$ com $\mathrm{Ti}$ e $\mathrm{Al}$ e $\mathrm{Fe}$ com Mg. Não é possível padronizar as diferenças entre as bordas e os núcleos, mas é possível separar bem os grãos analisados. O primeiro grão (Bt01) apresenta teores mais 
elevados de $\mathrm{X}_{\mathrm{Mg}}$ e $\mathrm{MgSi}$, e menores de $\mathrm{Fe}$ e Ti, o terceiro grão (Bt03) apresenta proporções mais elevadas de $\mathrm{Fe}$, Ti e $\mathrm{Al}$ e baixos teores de $\mathrm{X}_{\mathrm{Mg}}$ e $\mathrm{Si}$, o segundo grão (Bt02) apresenta-se intermediário ao primeiro e ao terceiro (Fig. 70).

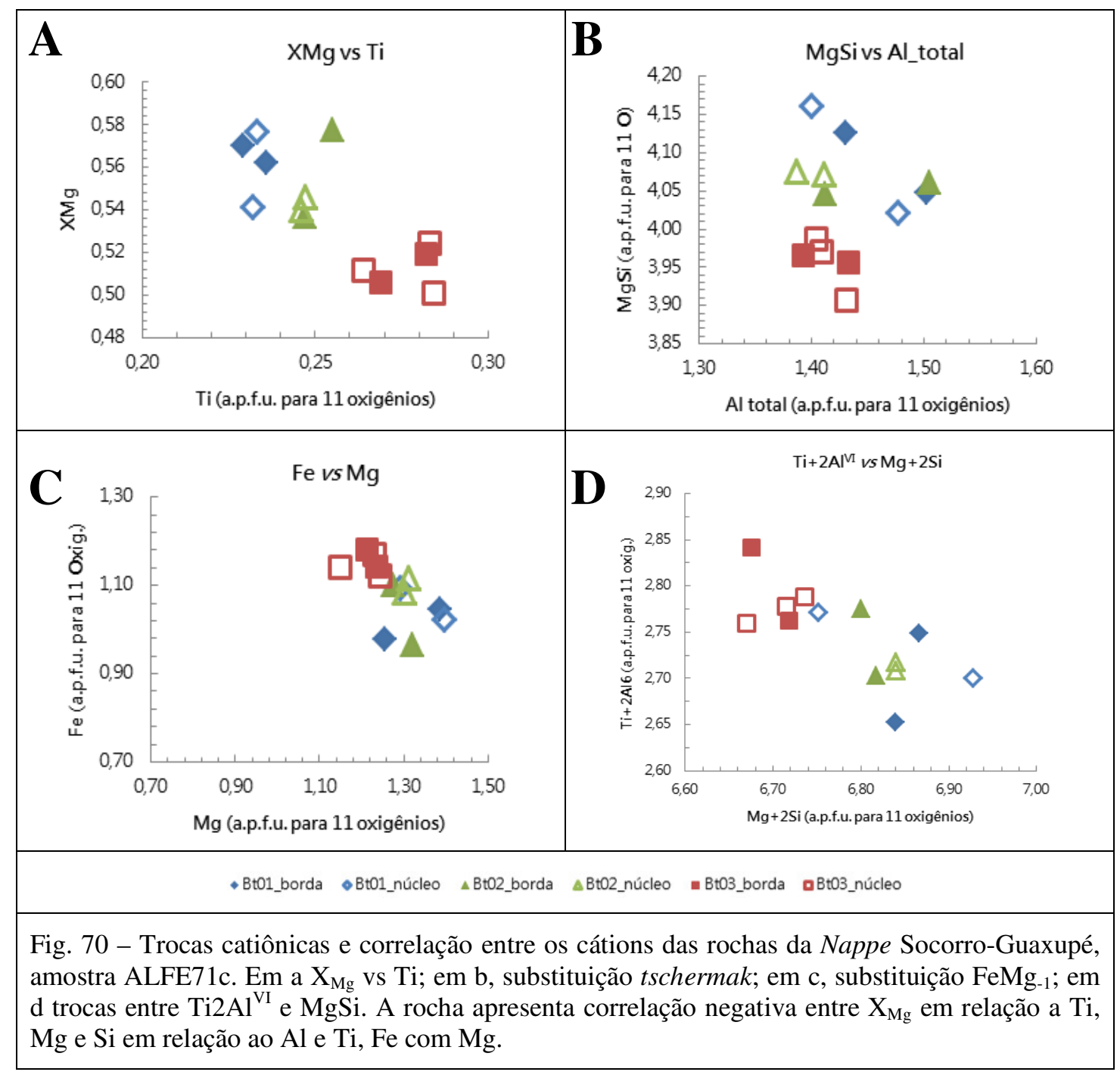

$\mathrm{Na}$ amostra ALFE71e1 foram analisados seis grãos na matriz da rocha. Os grãos apresentam-se estáveis com os outros minerais e estão orientados segundo a foliação principal. Não é possível estabelecer padrão entre bordas e núcleos, nem entre os grãos, pois se apresentam na forma de nuvens dispersa de pontos. A composição dos grãos analisados apresenta correlações negativas entre as trocas catiônicas de $\mathrm{X}_{\mathrm{Mg}}$ com $\mathrm{Ti}, \mathrm{Mg} \mathrm{e}$ Si com Al, Fe com Mg e Ti e Al com Mg e Si (Fig. 71). 


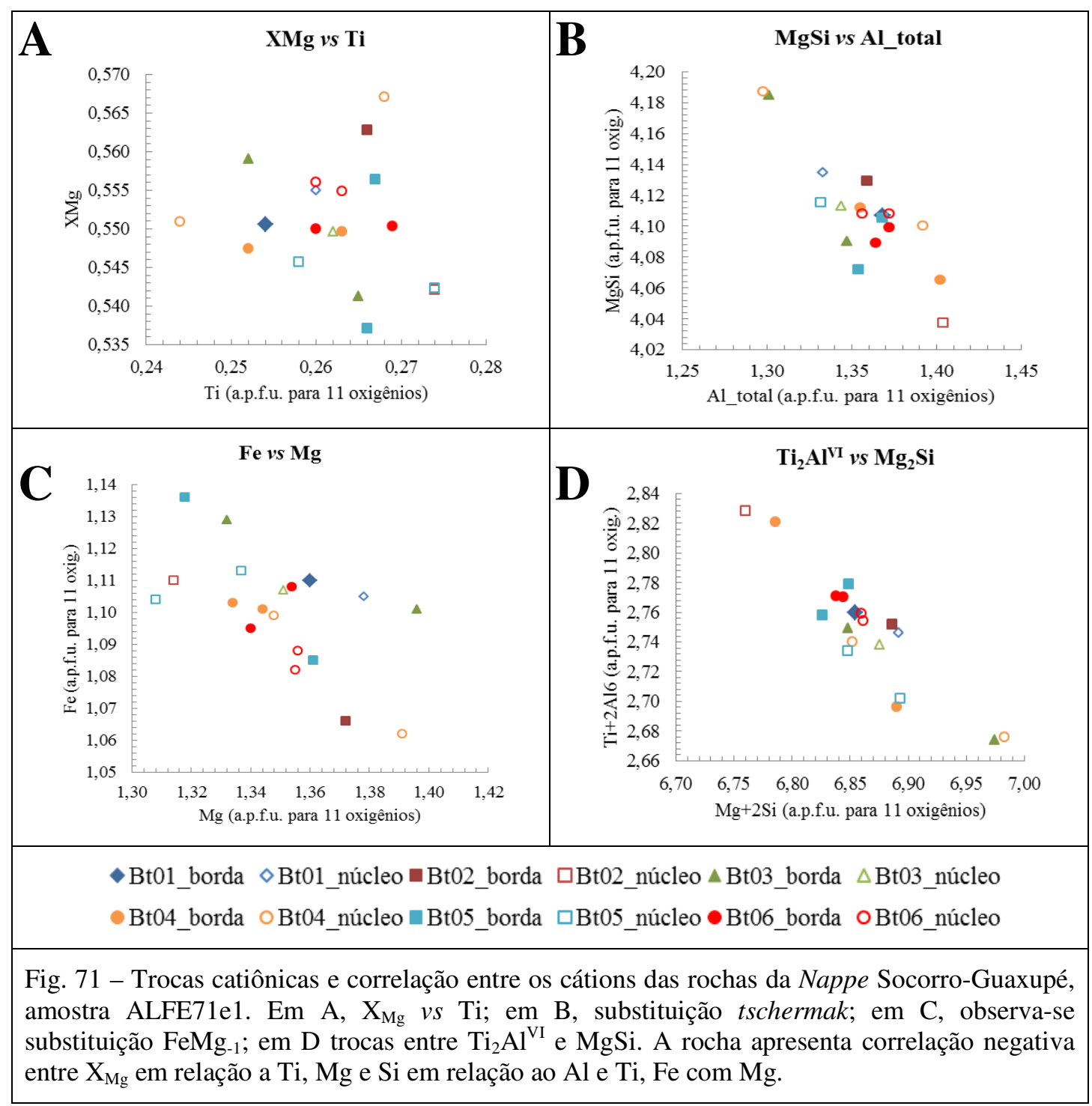




\section{Metamorfismo e termobarometria}

Metamorfismo é um processo em estado subsólido de transformação mineralógica, textural ou química de rochas no interior da terra à pressões e temperaturas variadas (Miyashiro, 1994). A termobarometria reúne os métodos usados para calcular essas condições de pressão e temperatura do metamorfismo, usando reações metamórficas específicas e a composição química dos minerais do pico do metamorfismo. Para determinar a temperatura (geotermômetros) são usadas reações que envolvem grandes variações de entropia e pequenas variações de volumes molares, onde há troca de elementos com raios iônicos semelhantes em sítios de mesma coordenação. Para determinar pressão (geobarômetros) são usadas reações com pequena variação de entropia e entalpia, mas com grandes variações dos volumes molares, e as trocas ocorrem entre elementos com raios iônicos diferentes e que ocupam sítios de coordenação diferentes (Spear, 1993).

Para o estudo do metamorfismo das rochas investigadas foi necessária a realização de petrografia, para determinar as paragêneses minerais e texturas mais evidentes do metamorfismo e de fusão, a análise da composição química dos minerais, o cálculo das fórmulas estruturais e, por fim, os cálculos de pressão e temperatura usando programas como PTMAFIC, (Soto \& Soto, 1995), THERMOCALC v3.26, com banco de dados de 2003 (Holland \& Powell, 2011) e fórmulas de geotermômetros e geobarômetros convencionais tabuladas no Excel®. Com os resultados foram usados diagramas de compatibilidade, diagramas de fases e grades petrogenéticas para cada unidade da área estudada.

As amostras selecionadas para o cálculo de pressão e temperatura foram: ALFE11a, ALFE24b, ALFE45ia, ALFE45N, ALFE45v1, ALFE45Va, ALFE71c e ALFE71E1, onde a relação de minerais analisados é apresentada na Tabela 01. Apenas as amostras 24b, 45Ia, 45N e 45V1 foram usadas para o cálculo de temperatura e pressão, por apresentarem paragêneses mais adequadas para o mesmo. 
Tabela 01 - Relação entre minerais e lâminas analisadas e os programas usados para o cálculo de pressão e temperatura.

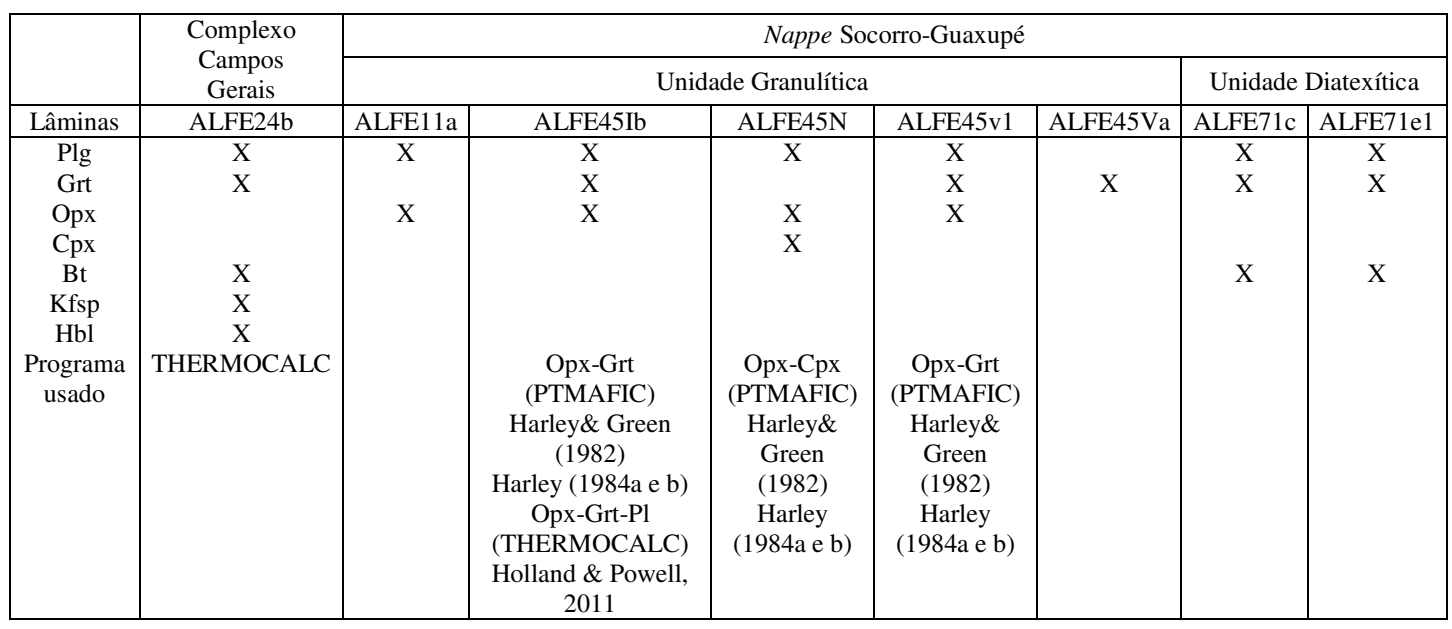

\subsection{Complexo Campos Gerais}

Para as rochas do Complexo Campos Gerais é difícil estimar as condições do pico metamórfico, primeiro por apresentarem mineralogia pouco favorável a estimativa do campo $P-T$ de estabilidade e por apresentarem estruturas reliquiares, como porfiroclastos tabulares de feldspato com bordas recristalizadas, feições deformacionais, como estruturas miloníticas, com porfiroclastos de feldspatos rotacionados e formando sigmóides, e estruturas de fusão, como leucossoma in situ ou cortando a foliação (Fig. 72 C-D). A possível paragênese de pico metamórfico observada nessas rochas é: granada + hornblenda + plagioclásio $\left(\mathrm{An}_{4,6-12,0} \mathrm{Ab}_{87,5-95,1} \mathrm{Or}_{0,1-3,8}\right)+$ feldspato potássico \pm biotita \pm fusão (Fig 73), a qual é representada pelo leucossoma.

Parte significativa dos grãos de biotita e, possivelmente, de hornblenda é retrometamórfica, pois substituiu a granada, mas vários grãos estão orientados segundo a foliação principal e devem estar em equilíbrio com os outros minerais citados que formam a paragênese da rocha. Muitas estruturas de fusão e deformação são vistas tanto em afloramentos (Fig 72 C-D), já citados anteriormente, como em microscópio, como cristais de quartzo e feldspatos vermiformes intersticiais a grãos maiores, formando string beads, ou cristais subidioblásticos com bordas recristalizadas (Fig. 72 A-B), indicando 
que a temperatura foi suficiente para fundir a rocha, sendo que para fundir o anfibólio é necessário temperaturas e pressões maiores que $925^{\circ} \mathrm{C}$ e $10 \mathrm{kbar}$ (Skjerlie et al, 1996).

As rochas do Complexo Campos Gerais afloram em zona de cisalhamento, o que facilitou o processo de hidratação, indicado pela presença de minerais hidratados e talvez da fusão, já que ocorrem veios tardios de leucossoma cortando a rocha. Durante o retrometamorfismo foram gerados de forma sucessiva hornblenda, biotita, muscovita, epidoto e carbonato, sendo que a substituição dos minerais de mais alta temperatura pode ocorrer de forma parcial ou quase que total, como por exemplo, a substituição do microclínio por muscovita (Fig. 72B).

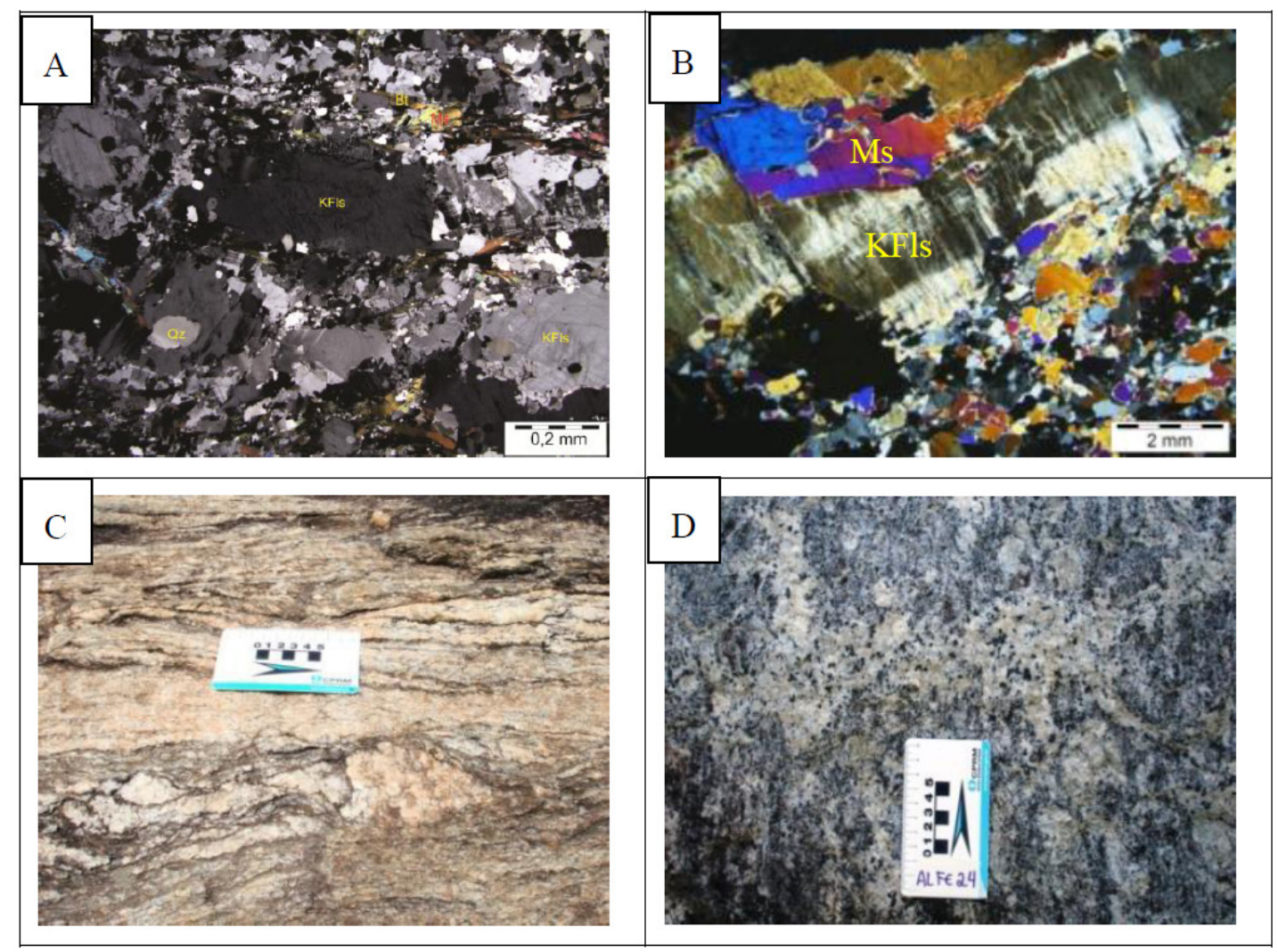

Fig. 72 - Fotomicrografica com polarizadores cruzados de textura ígnea preservada em A e B, com porfiroclástos de feldspatos tabulares, com bordas recristalizadas (lâmina ALFE24b e ALFE24e); em C; foto tirada do afloramento ALFE16, apresentando porfiroclásto de feldspato sigmoidal com vergência para ENE; em D foto tirada no afloramento ALFE24 mostrando fusão in situ, com leucossoma sendo formado e cortando a foliação. 


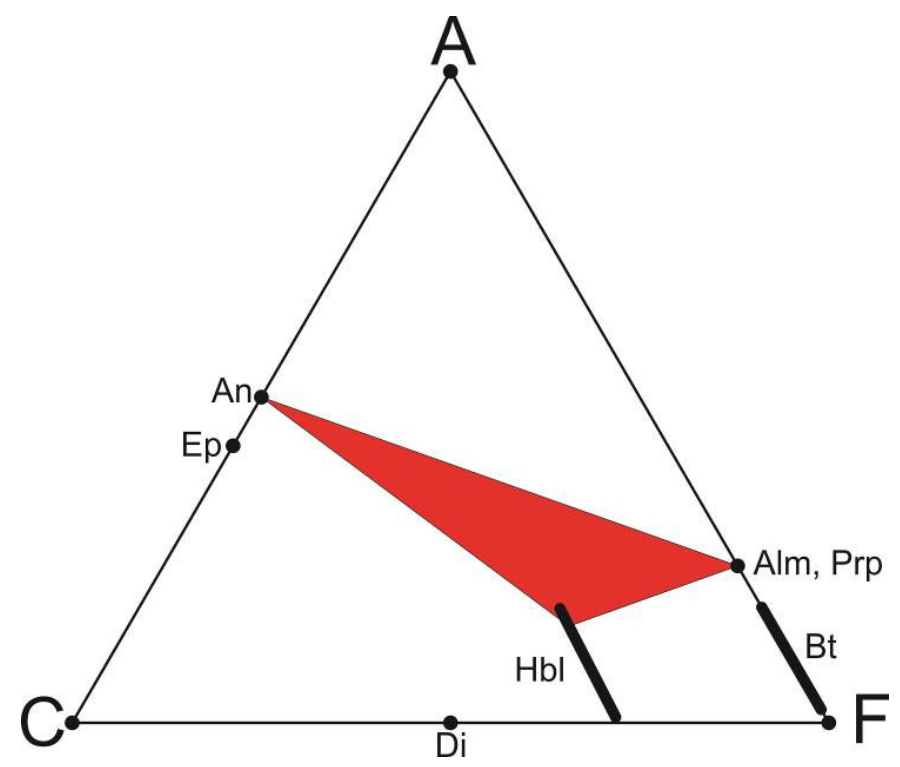

Fig. 73 - Diagrama de compatibilidade no sistema ACF com a paragênese do pico metamórfico da Unidade Campos Gerais, onde em vermelho indica a associação de minerais de pico metamórfico representado por granada-hornblenda-anortita.

Algumas reações cruzadas ao longo da trajetória $P-T$ para a rocha alcançar o pico metamórfico podem ser inferidas, como:

biotita + quartzo \pm epidoto $\pm \mathrm{H}_{2} \mathrm{O} \leftrightarrow$ anfibólio + granada + ortoclásio + plagioclásio + liquido

Para o cálculo de pressão e temperatura foi selecionada a amostra ALFE24b, em que quartzo, plagioclásio, granada, feldspato potássico e hornblenda estão em equilíbrio, e foram analisados. Foram separadas as análises que mais se adéquam ao cálculo e posteriormente processadas no programa Ax (Holland \& Powell, 2011), para cálculo das fórmulas estruturais e atividades dos membros finais de cada mineral (ANEXO 02). Com o programa THERMOCALC (Holland \& Powell, 2011) e a partir das atividades dos membros finais, um conjunto de reações linearmente independentes é encontrado pelo programa e o cálculo $P$ - $T$ é feito.

Para as rochas do Complexo Campos Gerais foram feitos cálculos $P-T$ com uma amostra contendo quartzo, plagioclásio, ortoclásio, granada, biotita e hornblenda, mas em dois campos diferentes. Usando o THERMOCALC os resultados de pressão são elevados, com valor de 13,3 $\pm 1,4$ kbar no primeiro campo e 17,6 $\pm 1,4$ kbar no segundo. Para o cálculo de temperatura dois valores muito diferentes foram obtidos, um deles baixo 
demais para as condições de fusão da rocha, como observado em campo, $560 \pm 166{ }^{\circ} \mathrm{C}$, e outro com valore mais dentro do esperado, $835 \pm 185^{\circ} \mathrm{C}$. Os altos valores de incertezas estão associados ao fato de que a rocha não apresenta paragênese ideal para o cálculo $P-T$, portanto os resultados de temperatura e pressão calculados pelo programa não são muito confiáveis, e devem ser considerados com cuidado. Mesmo assim, os resultados de pressão e temperatura calculados pelo THERMOCALC são condizentes com a paragênese da rocha e com as estruturas observadas em campo, tendo em média temperaturas de 835 a $925{ }^{\circ} \mathrm{C}$ e pressões entre 10 a 13 kbar. As disparidades nos resultados de cálculos $P-T$ podem ser efeito da dificuldade em definir realmente quais são os minerais do pico metamórfico, quais podem ser relíquias ígneas e, em virtude da intensa deformação com retrometamorfismo associado, saber quais fases são.

\subsection{Nappe Três Pontas-Varginha}

As rochas da Nappe Varginha-Três Pontas apresentam-se muito alteradas e muito cisalhadas na área estudada, inviabilizando a análise de química mineral, portanto as estimativas das pressões e temperaturas foram feitas a partir da posição das paragêneses em diagramas de fase e pseudosseções e, a partir daí, pela comparação com resultados de outros trabalhos feitos na região (Motta, 2001). A paragênese de pico metamórfico para essas rochas é (Fig. 74): cianita + granada + ortoclásio + quartzo + rutilo + líquido (representado pelo leucossoma).

A paragênese indica pressões mínimas acima de 10,5 kbar e temperaturas entre 850 e $900{ }^{\circ} \mathrm{C}$ (Fig. 75), o que é inferido pelo campo de estabilidade da paragênese e pela entrada de ortopiroxênio em rochas pelíticas. A paragênese é formada pela quebra da biotita e consumo de plagioclásio, o qual só está presente no leucossoma, o que permite fazer uma melhor inferência da pressão mínima quando examinamos as pseudosseções feitas para rochas semelhantes da Província Central do Grenville elaboradas por Indaires et al. (2008). O campo com quartzo + ortoclásio + granada + cianita + rutilo + líquido e sem plagioclásio indica que as pressões mínimas para a rocha em questão estão em torno de 15 kbar (Fig. 76). As possíveis reações para formar o pico metamórfico foram:

- biotita $+\mathrm{Al}_{2} \mathrm{SiO}_{5}+$ plagioclásio + quartzo $\leftrightarrow$ granada + ortoclásio + líquido

- quartzo + biotita(ss) $\leftrightarrow$ granada $+\mathrm{Al}_{2} \mathrm{SiO}_{5}+$ ortoclásio + líquido

- almandina + rutilo $\leftrightarrow$ ilmenita + cianita + quartzo 
A rocha está muito deformada e texturas miloníticas foram desenvolvidas, obliterando algumas texturas pretéritas e dificultando ainda mais a análise metamórfica, porém, sabe-se que a biotita e muscovita são minerais retrometamórficos, por estarem bordeando a granada e substituindo a cianita. A paragênese de retrometamorfismo é representada por: biotita+muscovita + ilmenita.

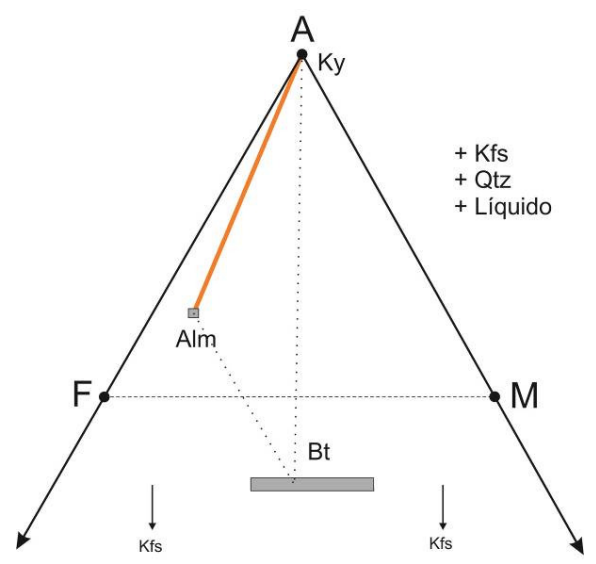

Fig. 74 - Diagrama de compatibilidade nos sistemas AFM para rochas metapelíticas da Nappe VarginhaTrês Pontas onde a paragênese de pico é formada por granada, cianita, ortoclásio e rutilo representada pela cor laranja no diagrama. $\mathrm{O}$ traço pontilhado representa o aparecimento de biotita no processo retrometamórfico.

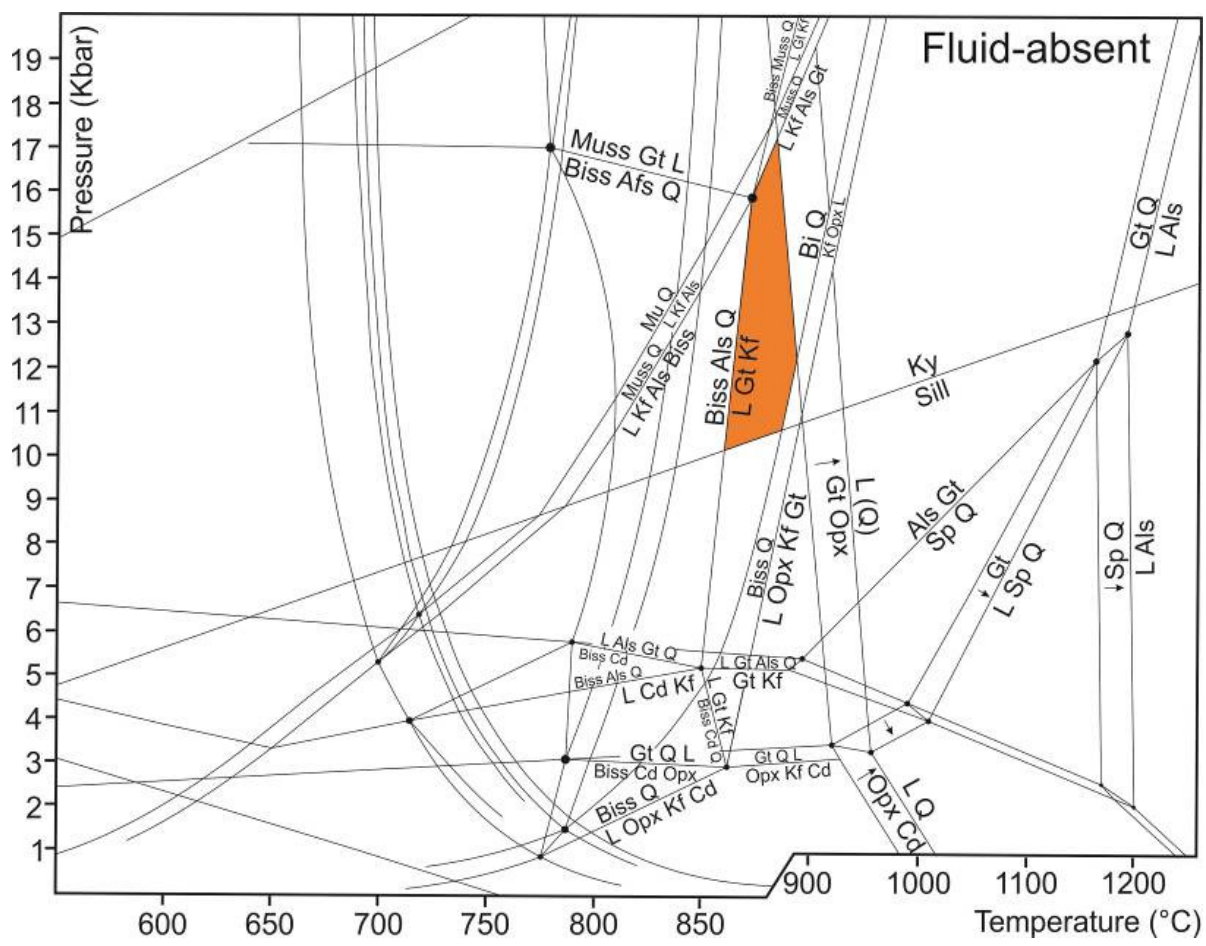

Fig. 75 - Diagrama $P-T$ com curvas experimentais de fusão para sistemas pelíticos na ausência de $\mathrm{H}_{2} \mathrm{O}$ (diagrama de Vielzeuf \& Holloway, 1988). Paragênese do pico metamórfico representado em laranja com a seguinte associação de minerais: granada-cianita-ortoclásio-rutilo. 


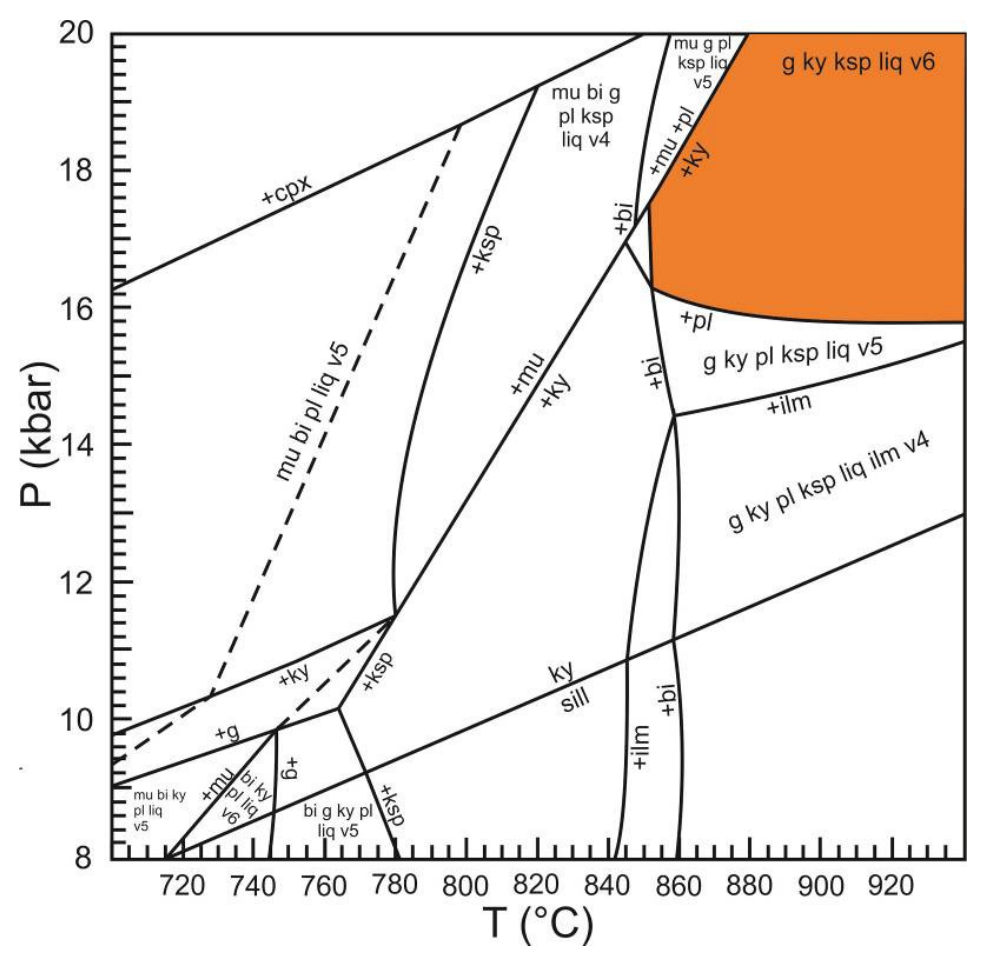

Fig. 76 - Pseudosseção calculada para rocha da província Grenville, cuja composição mineralógica é semelhante à das rochas da Nappe Varginha-Três Pontas. (sistema NCKFMASHTO $(+q+\mathrm{ru})$ ) (Indares et al., 2008). Paragênese do pico metamórfico representado em laranja com granada-cianita-ortoclásio-rutilo como associação de minerais do pico.

\subsection{Nappe Socorro-Guaxupé}

Da Nappe Socorro-Guaxupé foram investigados granulitos e diatexitos das unidades basal e intermediária. Boa parte dos granulitos são desprovidos de granada, sendo os félsicos, formados por ortopiroxênio, plagioclásio, ortoclásio, quartzo, ilmenomagnetita \pm granada \pm clinopiroxênio, com biotita e hornblenda retrometamórficas, enquanto os máficos apresentam praticamente a mesma associação, mas sem ortoclásio, com pouco quartzo. Os diatexitos apresentam muitos porfiroblastos de granada e rafts de biotita-hornblenda gnaisse, provável rocha parental, e lentes de granulitos. As rochas da NappeSocorro-Guaxupé na região estudada se apresentam muito retrometamorfisadas, dificultando a determinação da paragênese de pico metamórfico para ambas as unidades Granulítica e Diatexítica. Para tal, foi necessário o estudo petrográfico com ênfase nas rochas menos alteradas e retrometamórficas, o resultado foi a seleção das amostras ALFE11a, ALFE45Ib, ALFE45N, ALFE45V1 e ALFE45Va para unidade Granulítica e 
ALFE71C e ALFE71E1 para unidade Diatexítica. Para o cálculo da pressão e temperatura dessas rochas foram usadas grades petrogenéticas no sistema NKFMASH para altas temperaturas.

As amostras que melhor representam a paragênese de pico metamórfico das rochas da Nappe Socorro-Guaxupé são: ALFE45Ib, ALFE45N e ALFE45V1, as quais foram usadas nos cálculos $P-T$. Para a estimativa de pressão e temperatura da Unidade Diatexítica usou-se a petrografia e os campos de estabilidade das paragêneses presentes.

\subsubsection{Unidade Granulítica}

As rochas da Unidade Granulítica são as que representam as condições de pressão e temperatura da base da Nappe Socorro-Guaxupé. Para essas rochas foram identificadas duas paragêneses: $i$ ) clinopiroxênio + ortopiroxênio + plagioclásio \pm quartzo e ii) granada + ortopiroxênio + plagioclásio + quartzo + ortoclásio.

As paragêneses indicam pressões entre 6 e 10 kbar e temperaturas entre $850{ }^{\circ} \mathrm{C}$ e $950{ }^{\circ} \mathrm{C}$ (Fig. 77), geradas pela quebra da biotita para formar ortopiroxênio, granada e feldspato potássico concomitante com as reações de desidratação da hornblenda, gerando granada, ortopiroxênio e clinopiroxênio (Fig. 78). A pressão máxima é determinada pela presença de sillimanita em raros afloramentos em que o mineral foi reconhecido. As possíveis reações que geraram a paragênese da rocha foram:

- hornblenda + plagioclásio $\leftrightarrow$ clinopiroxênio + líquido $\leftrightarrow$ ortopiroxênio + líquido

- clinopiroxênio + quartzo + granada $\leftrightarrow$ ortopiroxênio + plagioclásio

- hornblenda + plagioclásio + quartzo $\leftrightarrow$ granada + clinopiroxênio + líquido (>10 kbar)

- hornblenda + quartzo \pm granada $\leftrightarrow$ ortopiroxênio + clinopiroxênio \pm plagioclásio + líquido $(<10$ kbar $)$

- hornblenda + plagioclásio I + quartzo $\leftrightarrow$ clinopiroxênio + ortopiroxênio + plagioclásio II + líquido

- hornblenda $\leftrightarrow$ plagioclásio + clinopiroxênio + ortopiroxênio $+\mathrm{H}_{2} \mathrm{O}$

- quartzo + hornblenda \pm plagioclásio $+\mathrm{H}_{2} \mathrm{O} \leftrightarrow$ ortopiroxênio + clinopiroxênio \pm granada + líquido

A rocha sofreu intenso retrometamorfismo evidenciado pelo excesso de hornblenda e biotita e por apresentar clinopiroxênio substituindo ortopiroxênio e hornblenda substituindo tanto clino- quanto ortopiroxênio. As relações texturais indicam sucessão dos seguintes minerais no retrometamorfismo: clinopiroxênio, hornblenda e biotita (Fig. 78). 


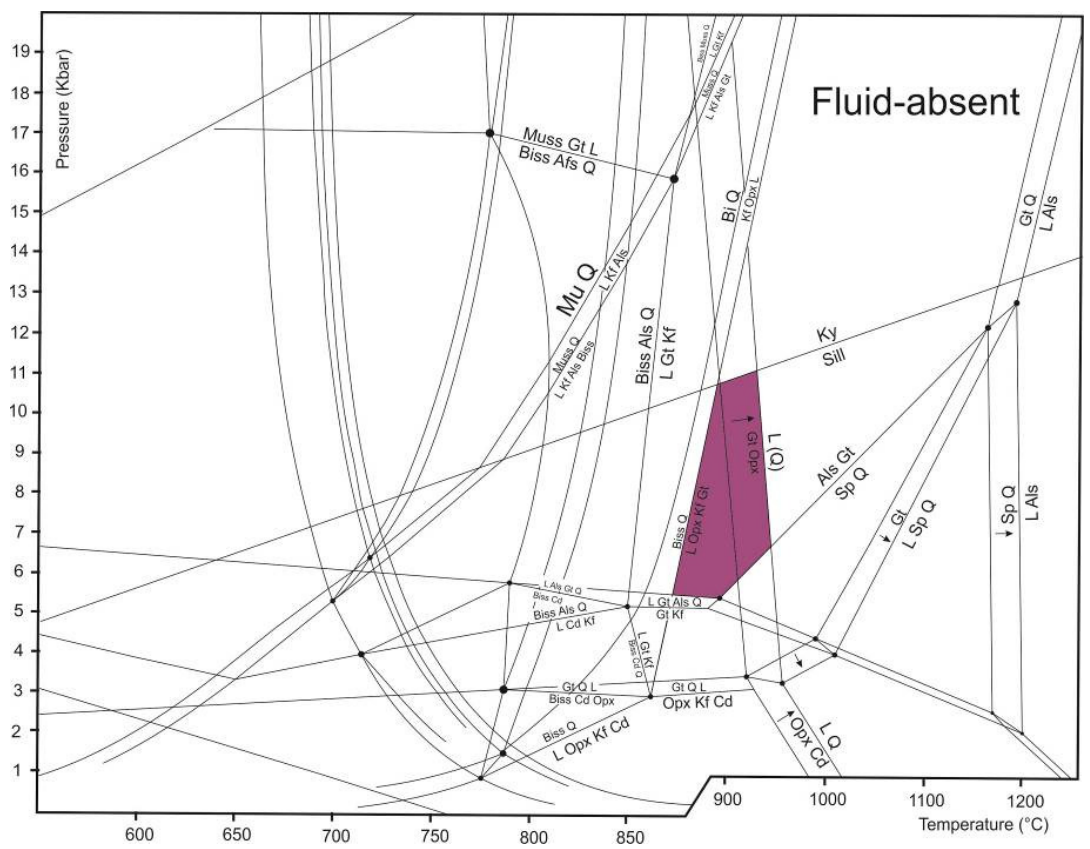

Fig. 77 - Diagrama $P-T$ com curvas experimentais de fusão para sistemas pelíticos na ausência de H2O. Em roxo está indicado o campo de estabilidade das rochas da unidade granulítica da Nappe Socorro-Guaxupé. Diagrama de Vielzeuf \& Holloway (1988).

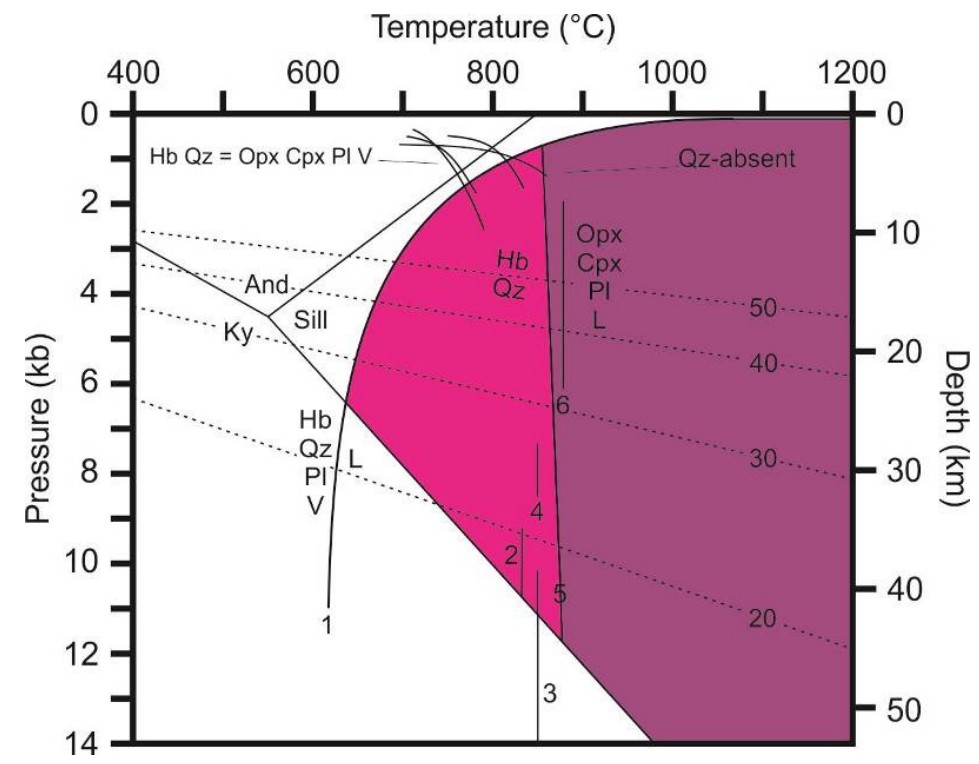

Fig. 78 - Diagrama $P$-T-profundidade mostrando as reações de desidratação e fusão da hornblenda. Variação em baixa pressão com reações de hornblenda com e sem quartzo. Reações calculadas por Choudhuri and Winkler (1967); Binns (1969); Spear (1981). Onde o campo de estabilidade da rocha é delimitado pela curva 5 , onde 5 representa a reação biotita + illmenita + quartzo + plagioclásio $=$ ortopiroxênio \pm granada + líquido, calculada por Patiño-Douce and Beard (1995). A cor roxa representa o campo de estabilidade da rocha no pico metamórfico e em rosa o retrometamorfismo. 
Para o cálculo de pressão e temperatura foram usadas duas amostras, coletadas a sul de Alfenas, na Pedreira Santa Terezinha. Na amostra ALFE45Ib foram selecionados grãos de granada, ortopiroxênio e plagioclásio tanto na matriz quanto no leucossoma da rocha, e foram usados os programas THERMOCALC, e diversos termômetros e barômetros, alguns disponíveis no programa PTMAFIC (Soto \& Soto, 1995). Além disso, o protocolo de recuperação de composição dos minerais descritos por Pattison \& Bégin (1994), usando as calibrações de Harley \& Green (1982) e Harley (1984a e b), também foi aplicado.

Com os grãos do leucossoma, analisados em dois campos diferentes, e o uso do THERMOCALC para o cálculo $P-T$, foram obtidas condições de pressão de $11.9 \pm 1.5$ kbar (ALF45I02a) e $11.8 \pm 1.3$ kbar (ALF45I02b), e que são resultados idênticos. Infelizmente no cálculo de temperatura o THERMOCALC não conseguiu encontrar um conjunto de reações linearmente independentes e nenhum resultado foi obtido. A temperatura foi obtida com o THERMOCALC calculando-se $P$ e $T$ ao mesmo tempo, mas mesmo assim os resultados não são satisfatórios, com valores bem mais baixos de $P-T$, no limite inferior da fácies granulito ou na fácies anfibolito. Além disso, o resultado apresenta altíssima correlação entre $P$ e $T(0,9)$, demonstrando que o resultado da temperatura é dependente da qualidade do resultado da pressão. Como esse é bem diferente do cálculo anterior, mais confiável, pois apenas uma variável foi calculada, conclui-se que o cálculo de temperatura não é confiável. Os resultados estão apresentados na tabela 2.

Tabela 2 - Relação de temperaturas e pressões obtidas pelo THERMOCALC nos dois campos analisados no leucossoma.

\begin{tabular}{lll}
\hline & ALF45i02a & ALF45i02b \\
\hline THERMOCALC P & $11.9 \pm 1.5 \mathrm{kbar}$ & $11.8 \pm 1.3 \mathrm{kbar}$ \\
& $\mathrm{T}=656 \pm 156^{\circ} \mathrm{C}$ & $\mathrm{T}=777 \pm 196^{\circ} \mathrm{C}$ \\
THERMOCALC & $\mathrm{P}=7.9 \pm 2.0 \mathrm{kbar}$ & $\mathrm{P}=9.2 \pm 2.5 \mathrm{kbar}$ \\
$($ média $P$ - $T$ ) & corr $=0.889$ & corr $=0.901$
\end{tabular}

As pressões e temperaturas calculadas para o leucossoma pelo THERMOCALC foram usadas como referência para os cálculos de pressão com o barômetro ortopiroxênio-quartzo-granada-plagioclásio, feitos com o programa PTMAFIC e com as calibrações de Harley \& Green (1982) e de Harley (1984 a e b). Os resultados indicam 
pressões em torno de 11,5 kbar para temperaturas de $850{ }^{\circ} \mathrm{C}$ (Tabela 3). Quando o método descrito por Pattison \& Bégin (1994) é aplicado para recuperar a composição dos minerais para recalcular as condições do pico metamórfico, pressão da ordem de 13,9 kbar é calculada e a temperatura do pico muda de $713{ }^{\circ} \mathrm{C}$ para $725{ }^{\circ} \mathrm{C}$. O método é ineficiente para recuperar temperaturas acima de $800{ }^{\circ} \mathrm{C}$, as quais são compatíveis com os dados experimentais de estabilidade de ortopiroxênio. Isso provavelmente se deve ao reequilíbrio químico muito intenso ocorrido nos grãos dentro do leucossoma.

Tabela 3 - Relação das pressões obtidas pelo PTMAFIC e pelas calibrações de Harley\& Green (1982) e de Harley (1984 a e b) para o leucossoma.

\begin{tabular}{ll}
\hline & P (kbar) \\
\hline Newton \& Perkins (1982) & 11.3 \\
Perkins \& Chipera (1985) & $11.4(\mathrm{Mg})$ \\
Perkins \& Chipera (1985) & $11.1(\mathrm{Fe})$ \\
Powell \& Holland (1988) & 21.3 \\
Eckert et al. (1991) & 11.8 \\
\hline
\end{tabular}

Para o granulito, na mesma lâmina, foram usados dois campos de uma lâmina com a mesma paragênese constituída de quartzo + ortopiroxênio + granada + plagioclásio (ALF45i04 e ALF45i05)(ANEXO02). Usando o THERMOCALC, o programa conseguiu estabelecer conjuntos de reações linearmente independentes para o cálculo de pressão, de temperatura e de média de pressão e temperatura. Para o cálculo de temperatura, só foi possível estabelecer conjuntos de reações linearmente independentes para um dos campos (ALF45i05, ver tabela 4). Os resultados de pressão não são diferentes dos calculados para o leucossoma, entre 9,5 e 10,5 kbar e temperatura de $868 \pm 62{ }^{\circ} \mathrm{C}$. Quanto ao método média $P-T$, o programa também não conseguiu estabelecer um conjunto de reações linearmente independentes para um dos campos (ALF45i05, ver tabela 4) e quando é usado no outro campo as condições são de 9 kbar e $808 \pm 190{ }^{\circ} \mathrm{C}$ com alta correlação $(0,88)$. 
Tabela 04 - Relação de temperaturas e pressões obtidas pelo THERMOCALC nos dois campos analisados no granulito.

\begin{tabular}{lll}
\hline THERMOCALC & ALF45i04 & ALF45i05 \\
\hline $\mathrm{P}$ & $10.53 \pm 1.07 \mathrm{kbar}$ & $9.50 \pm 1.12 \mathrm{kbars}$ \\
& $868 \pm 62^{\circ} \mathrm{C}$ & $\mathrm{X}$ \\
$\mathrm{T}$ & & $\mathrm{T}=808 \pm 190^{\circ} \mathrm{C}$ \\
& & $\mathrm{P}=9.1 \pm 2.3 \mathrm{kbars}$ \\
$($ média $P-T)$ & corr $=0.883$ \\
\hline
\end{tabular}

As pressões e temperaturas calculadas com o THERMOCALC para o granulito serviram de referência para os outros cálculos de pressão com os mesmos métodos usados para o leucossoma, com o barômetro ortopiroxênio - quartzo - granada - plagioclásio, do PTMAFIC e com as calibrações de Harley \& Green (1982) e de Harley (1984 a e b), os resultados indicaram pressões em torno de 11,3 kbar para o primeiro campo e 11,5 kbar par o segundo campo, ambos calculados com temperaturas de $850{ }^{\circ} \mathrm{C}$ (Tabela 5). Quando é aplicado o método de Pattison \& Bégin (1994) a pressão calculada aumenta relativamente, sendo em ALF45i04 pressão de 17,87 kbar e a temperatura muda de 718 ${ }^{\circ} \mathrm{C}$ para $727{ }^{\circ} \mathrm{C}$ e em ALFE45i05, pressões de 13,90 kbar e a temperatura muda de 758,6 ${ }^{\circ} \mathrm{C}$ para $731{ }^{\circ} \mathrm{C}$, tornando assim o método ineficiente para cálculos com as temperaturas compatíveis com os dados experimentais de estabilidade de ortopiroxênio $\left(>800^{\circ} \mathrm{C}\right)$. Assim como no leucossoma, isso se deve ao reequilíbrio químico ocorrido nos grãos.

Tabela 5 - Relação das pressões obtidas pelo PTMAFIC e pelas calibrações de Harley\& Green (1982) e de Harley (1984 a e b) para os granulitos. (Dados em kbar).

\begin{tabular}{lll}
\hline & ALF45i04 & ALF45i05 \\
\hline Newton \& Perkins (1982) & 11.3 & 11.55 \\
Perkins \& Chipera (1985) & $11.24(\mathrm{Mg})$ & $11.6(\mathrm{Mg})$ \\
Perkins \& Chipera (1985) & $11.01(\mathrm{Fe})$ & $11.75(\mathrm{Fe})$ \\
Powell \& Holland (1988) & 21.34 & 21.25 \\
Eckert et al. (1991) & 11.79 & 11.98 \\
\hline
\end{tabular}


Na amostra ALFE45V1 foram selecionados grãos de granada e ortopiroxênio da matriz da rocha. Usando os valores de referência das amostras anteriores, os cálculos de pressão foram feitos com geobarômetro ortopiroxênio-granada usado pelo PTMAFIC. As temperaturas para essa amostra foram calculadas com calibração de Harley \& Green (1982) e de Harley (1984 a e b) que geraram resultados em torno de 800 a $900{ }^{\circ} \mathrm{C}$ para temperatura e de 19 a 23 kbar para pressão.

Os resultados dos cálculos indicam que a rocha sofreu metamorfismo de fácies granulito, com pico metamórfico entre 800 a $950{ }^{\circ} \mathrm{C}$ e pressões em torno de 9 a $11 \mathrm{kbar}$, e passou por intenso processo de migmatização acompanhado de hidratação causando retrometamorfismo em fácies anfibolito, evidenciado pela presença de hornblenda e biotita, em torno de 650 a $850{ }^{\circ} \mathrm{C}$ e 7 a 11 kbar. Alguns resultados são suspeitos por extrapolarem os valores condizentes com a paragênese observada na rocha e podem indicar reequilíbrio dos minerais durante o resfriamento.

\subsubsection{Unidade Diatexítica}

As rochas da Unidade Diatexítica apresentam taxa de fusão muito alta, dificultando o reconhecimento da paragênese de pico metamórfico. São rochas de composição mais pelítica que as rochas da unidade granulítica, por apresentarem maior quantidade de fundido, menor quantidade de porções máficas, cristais de granadas extremamente grandes e composição muito quartzo-feldspática aluminosa (protólito arenítico) e com paragênese hidratada, fazendo com que as temperaturas de pico metamórfico sejam menores. Para o cálculo da pressão e temperatura utilizou-se apenas grades petrogenéticas com dados experimentais de reações de fusão de granitóides com biotita ou hornblenda. A rocha apresenta como paragênese de pico metamórfico: granada+ hornblenda + plagioclásio + feldspato potássico + quartzo.

A paragênese foi formada a partir da quebra da biotita para gerar hornblenda e granada, mas as condições $P$ - $T$ não devem ultrapassaras o campo de estabilidade da hornblenda. Uma possível reação para formação da paragênese é:

- biotita + quartzo + plagioclásio $\leftrightarrow$ feldspato potássico \pm granada + líquido

- biotita + quartzo + epidoto $\leftrightarrow$ hornblenda + granada+ feldspato potássico + plagioclásio + líquido

- biotita + plagioclásio $\leftrightarrow$ granada + hornblenda + líquido 
Como a paragênese é restrita pelas reações de quebra de biotita e hornblenda, é possível estimar o campo de estabilidade da rocha que varia entre 750 a $950{ }^{\circ} \mathrm{C}$ (Fig. 79). As pressões foram definidas pelo campo de estabilidade da sillimanita que é o aluminossilicato observado em um único afloramento de rocha pelítica com granada e sillimanita dentro da Unidade Granulítica um pouco a norte do contato com a Unidade Diatexítica da Nappe Socorro-Guaxupé.

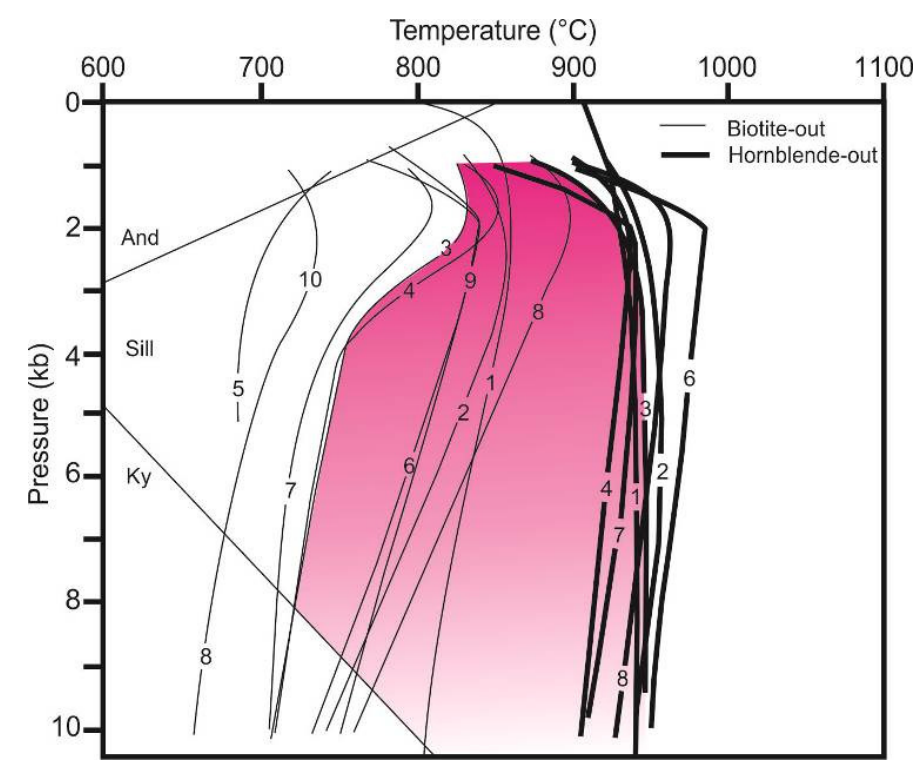

Fig. 79 - Diagrama experimental $P$ - $T$ mostrando reações de quebra da biotita e da hornblenda para várias composições graníticas. Em rosa, o campo de estabilidade das rochas da unidade diatexítica da Nappe Socorro-Guaxupé, delimitado pelas curvas de número 3, calculadas para granodioritos, por Piwinskii (1973a). 


\section{Discussão e Conclusão}

$\mathrm{Na}$ área estudada são identificadas três unidades ligadas, pelo contexto tectônico, a evolução neoproterozóica do Orógeno Brasília. Na base estrutural desse pacote estão as rochas do Complexo Campos Gerais, sobrepostas pelas rochas da Nappe Três PontasVarginha, que por sua vez estão sotopostas pelas rochas da Nappe Socorro-Guaxupé, que é dividida em Unidade Granulítica (basal) e Unidade Diatexítica (intermediária).

O Complexo Campos Gerais está intensamente deformado em zona de cisalhamento, de movimento sinistral e com componente normal com movimentação de topo para SW. Dois tipos litológicos dominam o complexo, bioita gnaisse migmatítico que está exposta e domina a porção norte da área mapeada e hornblenda-biotita-granada gnaisse migmatítico, mais próximo da zona de cisalhamento, ao sul. Intercalado aos dois tipos é possível observar lentes de rocha ultramáfica. A rocha que melhor representa a paragênese para calcular o campo $P-T$ da unidade é a hornblenda-biotita-granada gnaisse migmatítico, com granada - biotita- hornblenda - plagioclásio - feldspato potássico como minerais que compõe a paragênese de pico metamórfico. Os cálculos termobarométricos para essas rochas apresentam resultados de temperaturas entre 835 a $925{ }^{\circ} \mathrm{C}$ e pressões entre 10 a 13 kbar. Porém as incertezas nos cálculos, que não fornecem resultados homogêneos, não são pequenas. Alguns problemas podem estar ligados ao fato de que é difícil nessas rochas saber exatamente quais fases realmente estavam em equilíbrio no pico metamórfico, algumas são rochas ortoderivadas, migmatizadas e cisalhadas de forma intensa, combinação de fatores que dificulta a definição de quais são os minerais do pico metamórfico, quais podem ser relíquias ígneas da rocha original, ou mesmo cristalização de líquido aprisionado da migmatização e, além disso, por cima disso ainda ocorre intensa deformação e retrometamorfismo.

A Nappe Três Pontas-Varginha é composta por granulitos aluminosos, cuja paragênese de pico metamórfico é composta por granada - cianita - rutilo - ortoclásio quartzo - líquido (representado pelo leucossoma), o que indica alta pressão. Com essa paragênese foram inferidas condições de pressão e temperatura em torno de $850-900{ }^{\circ} \mathrm{C}$ e 10,5 a 15 kbar, indicando que a rocha sofreu metamorfismo de fácies granulito de alta pressão.

A Nappe Socorro-Guaxupé é dividida em duas unidades, a Unidade Granulítica, considerada basal, e a Unidade Diatexítica que é intermediária. A Unidade Granulítica 
apresenta duas paragêneses distintas de pico metamórfico, uma composta por granada ortopiroxênio - plagioclásio - feldspato potássico e a outra composta por clinopiroxênio ortopiroxênio - plagioclásio \pm granada, dependendo se o granulito é félsico ou máfico, respectivamente. Com essas paragêneses foram estimada as condições $P-T$ do pico metamórfico, com temperaturas em torno de $850-950{ }^{\circ} \mathrm{C}$ e pressões de 6 a $10 \mathrm{kbar}$. Quando o cálculo é feito por geotermômetros e geobarômetros as pressões calculadas foram de $11 \mathrm{kbar}$, com margem de erro pequena e bom grau de confiabilidade. As temperaturas calculadas usando granada e ortopiroxênio são 720 a $760{ }^{\circ} \mathrm{C}$, abaixo do campo de estabilidade do ortopiroxênio $\left(>800{ }^{\circ} \mathrm{C}\right)$, sendo assim, o método usado é ineficiente para o cálculo de temperaturas para essas rochas. O cálculo de temperatura para uma das amostras indicou condições de $870{ }^{\circ} \mathrm{C}$, usando o THERMOCALC e essa temperatura parece ser o melhor resultado calculado para essas rochas. Foi observado que a rocha sofreu retrometamorfismo de fácies anfibolito devido à presença de hornblenda e biotita que substituem boa parte dos minerais anidros da rocha. Portanto a rocha sofreu metamorfismo em fácies granulito com pico $P-T$ de 11 kbar e $870{ }^{\circ} \mathrm{C}$, com retrometamorfismo de fácies anfibolito.

As rochas da unidade diatexítica apresentam grau de fusão elevado gerando paragênese de pico metamórfico composta por granada - hornblenda - plagioclásio feldspato potássico - quartzo, que indica temperaturas em torno de 750-950 ${ }^{\circ} \mathrm{C}$. Com essa paragênese não é possível estimar pressão, devido ao amplo campo de estabilidade dos minerais, portanto, essa foi estimada pela presença de lentes de metassedimentos com granada e sillimanita que sofreram o mesmo processo tectônico e metamórfico que as rochas dessa unidade, limitando assim, as pressões para o campo de estabilidade da sillimanita, ou seja, $P<10$ kbar.

Com o mapeamento geológico feito na área é possível perceber que existem algumas inconsistências com o mapa regional de Campos Neto et al. (2007). A sequência de empilhamento aqui definida na área estudada é, de norte para sul, composta pelo Complexo Campos Gerais, seguida pela Nappe Três Pontas-Varginha, logo acima a Unidade Granulítica da Nappe Socorro-Guaxupé sobreposta pela Unidade Diatexítica da mesma Nappe (ver mapa e perfil geológicos). De acordo com Campos Neto et al. (2007), entre o Complexo Campos Gerais e a Nappe Três Pontas-Varginha existem rochas do Grupo Carrancas e acima da unidade granulítica viria a Unidade Metatexítica da Nappe Socorro-Guaxupé. No entanto as rochas metassedimentares do Grupo Carrancas não foram reconhecidas, nem a Unidade Metatexítica. 
Mesmo com grandes incertezas, de modo geral pode-se dizer que as pressões aumentam de sul para norte, em aumento quase que contínuo entre as rochas da Nappe Socorrro-Guaxupé e Três Pontas-Varginha. Além disso, não há variação termométrica significativa entre as unidades mapeadas, indicando que sofreram o mesmo processo metamórfico e que as variações estruturais encontradas entre elas se dão pela variação composicional, pela porcentagem de água no sistema e pela taxa de fusão de cada uma.

Alguns dos resultados calculados para as condições $P-T$ pelo THERMOCALC se mostraram ineficiente por diferirem muito dos valores condizentes com as paragêneses observadas, podendo indicar reequilíbrio dos minerais durante o resfriamento.

As rochas da Nappe Socorro-Guaxupé sofreram metamorfismo de fácies granulito com temperaturas em torno de $870{ }^{\circ} \mathrm{C}$ e pressões de $11 \mathrm{kbar}$. As condições de fusão e metamorfismo para as rochas do Complexo Campos Gerais e Nappe Três PontasVarginha foram apenas inferidas e um estudo mais aprofundado será necessário para melhor definição, e para estas últimas áreas vizinhas terão que ser investigadas, pois na região em que a unidade aflora entre Alfenas e Fama, os afloramentos são de rochas muito intemperizadas. 


\section{Referências Bibliográficas}

Behr, H. J.; Tex, E. den; Waard, D.; Mehnert, K. R.; Scharbert, H. G.; St. Sobolev, V.; Watznauer, A.; Winkler, H. G. F.; Wynne-Edwards, H. R.; Zoubek, V.; Zwart, H. J., 1971. Granulites: results of a discussion. N. Jahrbuch f. Mineralogie. Monatshefte, 1: $97-123$.

Brito Neves, B. B.; Campos Neto M. C. \& Fuck, R. A., 1999. From Rodinia to western Gondwana: an approach to the Brasiliano-Pan African Cycle and orogenic collage. Episodes, 22:155-166.

Brito Neves, B. B.; Sá J. M.; Nilson, A. A.; Botelho, N. F.; 1995. A Tafrogênese Estateriana nos blocos Paleoproterozóicos da América do Sul e processos subseqüentes. Geonomos, 3(2): $1-21$.

Campos Neto, M. C., 2000. Orogenic Systems from SW-Gondwana: An approach to BrasilianoPan African Cycle and orogenic collage in SE-Brazil. In: Umberto Cordani; Antonio Thomaz Filho; Edison José Milani. (Org.). Tectonic Evolution of South America. 1 ed. Rio de Janeiro: Companhia de Pesquisa de Recursos Minerais (CPRM), 1: 335-365.

Campos Neto, M. C.; Basei, M. A. S.; Vlach, S. R. F.; Caby, R.; Szabó, G. A. J.; Vasconcelos, P., 2004. Migração de orógeno e superposição de orogêneses: um estudo da colagem brasiliana no sul do cráton do São Francisco, SE - Brasil. Revista do Instituto de Geociências - USP. Geologia USP Série Científica, 4: 13-40.

Campos Neto, M. C.; Caby, R., 1999. Neoproterozoic high-pressure metamorphism and tectonic constraint from the Nappe system south of the São Francisco Craton, southeast Brazil. Precambrian Research, 97: 3-26.

Campos Neto, M. C.; Caby, R., 2000. Terrane accretion and upward extrusion of high-pressure granulites in the Neoproterozoic Nappes of southeast Brazil: petrologic and structural constraints. Tectonics, 19(4): 669-687.

Campos Neto, M. C.; Janasi, V. A.; Basei, M. A. S.; Siga Jr, O., 2007. Sistemas de Nappes Andrelândia, setor oriental: litoestratigrafia e posição estratigráfica. Revista Brasileira de Geociências, 37 (4 - suplementos): 47-60.

Cavalcante, J. C.; Cunha, H. C. S.; Chieregati, L. A.; Kaefer, L. Q.; Rocha, J. M.; Daitx, E. C.; Coutinho, M. G. N.; Yamamoto, K.; Drumond, J. B. V.; Rosa, D. B.; Ramalho, R., 1979. Projeto Sapucaí: Relatório Final de Geologia. São Paulo, S.P., DNPM/CPRM. 615 p..

Dardenne, M. A., 2000. The Brasilia fold belt. In: Cordani, U. G.; Milani, E. J.; Thomaz Filho, A.; Campos, D. A. (Eds) Tectonic Evolution of South America. Rio de Janeiro. p 231263.

Deer W. A.; Howie, R. A.; Zussman, J., 1982, Rock-forming minerals vol.1a: Orthosilicates. Londres, Liongman, 02(2): 919p.

Del Lama, E. A.; Oliveira, M. A. F.; Zanardo, A., 1998. Geochemistry of the Guaxupé Granulites Minas Gerais, Brazil. Gondwana Research, 1: 357-365.

Del Lama, E. A.; Zanardo, A.; Oliveira, M. A. F.; Morales, N., 2000. Exhumation of highpressure granulites of the Guaxupé Complex, southeastern Brazil. Geological Journal, 35: 231-249.

Freitas, F. C., 2000. Geotermobarometria e evolução metamórfica das rochas granulíticas da região de Socorro (SP). Dissertação de Mestrado. IGc-USP, São Paulo, 166 p. 
Freitas, F. C., 2006. Evolução metamórfica dos terrenos granulíticos de Socorro, Caconde (SP) e Cambuí (MG). Tese de Doutoramento. IGc-USP, São Paulo, 197 p.

Frost, B. R. \& Chacko, T., 1989. The granulite uncertainity principle: limitations on thermobarometry in granulites. Journal of Geology, 97: 435-450.

Fuck, R. A.; Pimentel, M. M.; Silva, L. J. H. D. 1994. Compartimentação tectônica da porção oriental da Província Tocantins. In: SBG, Anais do $\mathrm{XXX}^{\mathrm{VI} I}$ Congresso Brasileiro de Geologia, Balneário Camboriú, 1: 215-216.

Fyfe, W. S., 1973. The granulite fácies, partial melting and the Archean crust. Phil. Trans. R. Soc., London, 273(A): 457-461.

Garcia, M. G. M., 2001. Associações metamórficas de alta pressão: Nappes neoproterozóicas a sul do Craton São Francisco. Tese de doutoramento. Instituto de Geociências. Universidade de São Paulo. São Paulo. 195p

Garcia, M.G.M., Campos Neto, M.C., 2003. Contrasting metamorphic conditions in the Neoproterozoic collision - related nappes south of São Francisco Craton, SE Brazil. Journal of South America Earth Sciences, 15: 853-870.

Garda, G. M.; Atencio, D., 1990. Nomenclatura dos Piroxênios. Tradução do Original Em Inglês "Nomenclature Of Pyroxenes", Por N. Morimoto, Realizada Com Permissão da Ima. Revista Brasileira de Geociências, São Paulo, 20(1-4): 318-328.

Garda, G. M.; Atencio, D., 1991. Nomenclatura dos Anfibólios. Tradução do Original Em Inglês: "Nomenclature Of Amphiboles", Compilado Por B.E. Leake, Realizada Com Permissão da Ima. Revista Brasileira de Geociências, São Paulo,.21(3): 285-297.

Guo-Neng, C.; Grapes, R., 2007. Granite genesis: in-situ melting and crustal evolution. 278 p.

Harley, S. L., 1989. The origins of granulite: a metamotphc perspective. Geological Magazine, 126(3): $215-247$

Harley, S. L., 1992. Proterozoic granulites terranes. In: Condie, K. C., (ed) Proterozoic crustal evolution developments in Precambrian geology, Elsevier, Amsterdã, 10: 301-360.

Hasui, Y., 2009. A grande colisão pré-cambriana do Sudeste brasileiro e a estruturação regional. Geociências, São Paulo, 29(2): 141-169.

Heilbron, M.; Pedrosa Soares, A. C.; Campos Neto, M. C.; Silva, L. C.; Trouw, R. A. J.; Janasi, V. A., 2004. Província Mantiqueira. In: Virgínio Mantesso-Neto; Andréa Bartorelli; Celso Dal Ré Carneiro; Benjamim Bley de Brito Neves. (Org.). Geologia do Continente Sul Americano: Evolução da Obra de Fernando Flávio Marques de Almeida. $1^{\circ}$ ed. São Paulo, 1: 203-234.

Helwing, J., 1974. Eugeosynclinal basement and collage concept of orogenic belts. In: Helwing, J., Modern and ancient geosynclinal sedimentation. Tulsa: Society of Economic Paleontologists and Mineralogists, 19: 359-376.

Holland, T. B. J. \& Powell, R., 1998. An internally consistent thermodynamic data set for phases os petrological interest. Journal of Metamorphic Geology, 16(3): 309-343.

Holland, T. B. J. \& Powell, R., 2011. An improved and extended internally consistent thermodynamic dataset for phases of petrological interest, involving a new equation of state for solids. Journal of Metamorphic Geology; 29: 333-383.

Holness, M. B. \& Sawyer, E. W., 2008. On the pseudomorphing of melt-filled pores during the crystallization of migmatitos. Journal of Petrology. 49(7): 1343-1363.

Indares, A.; White, R. W., Powell, R., 2008. Phase equilibria modelling of kyanite-bearing anatectic paragneisses from the central Grenville Province. Journal of Metamorphic geology. 26: 815-836. 
Iyer, S. S.; Choudhuri, A.; Pattison, D. R. M.; De Paoli, G. R., 1996. Petrology and geochemistry of the Neoproterozoic Guaxupe granulite facies terrain, southeastern Brazil. Precambrian Research, 77: 23-40.

Janasi V. A. 1999. Petrogênese de granitos crustais na Nappe de empurrão Socorro-Guaxupé (SPMG): uma contribuição da geoquímica elemental e isotópica. Tese de Livre-Docência, IG/USP, 304p.

Janasi V. A., Campos Neto M. C., Vasconcellos A. C., Van Schmus W. R., Garcia M. G. M. 2000. Geochemical and isotopic ( $\mathrm{Nd}, \mathrm{Sr}$ ) evidences for a Neoproterozoic juvenile component in metasediments from allochtonous terranes in the southern Brasília Belt, Brazil. In: International Geological Congress, 3, Rio de Janeiro, RJ, Abstracts and CDROM.

Janasi, V.A., 2002. Elemental and Sr-Nd isotope geochemistry of two Neoproterozoic mangerite in SE Brazil: implications for the origin of the mangerite-charnockite-granite series. Precambrian Research, 119: 301-327.

Kriegsman, L. M., 2001. Partial melting, partial melt extraction and partial back reaction in anatectic migmatitos. Lithos, 56: 75-96.

Leake, E.B.;Woolley, A.R.; Arps, C.E.S.; Birch, W.D.; Gilbert, M.C.; Grice, J.D.; Howthorne, F.C.; Kato, A.; Kisch, H.J.; Krivovichev, V.G.; Linthout, K.; Laird, J.; Mandarino, J.A.; Maresch, W.V.; Nickel, E.H.; Schumacher, J.C.; Smith, D.C.; Stephenson, N.C.N.; Ungaretti, L.; Whittaker, E.J.W.; Youzhi, G.; 1997. Nomenclature of anphiboles: report of the subcommittee on amphiboles os the international mineralogical association, commission on new minerals and mineral name. The Canadian Mineralogist, 35: 219246

Miyashiro, A., 1974. Classification, characteristic and origin of anphibolite. Journal of Geology, 83(2): 249-2481.

Miyashiro, A., 1994. Metamorphic Petrology. UCL Press, London, 404 pp.

Montel, J. M.; Vielzeuf, D., 1997. Partial melting of metagreywackes. Part II. Compositions of minerals and melts. Contribution to Mineralogy and Petrology. 128: 176-196.

Moraes, R.; Brown, M.; Fuck, R. A.; Camargo, M. A.; Lima, T. M., 2002. Characterization and P$\mathrm{T}$ evolution of melt-beaning ultrahigh-temperature granulites: na example from the Anápolis-Itauçu Complex of the Brasília Fold Belt, Brazil. Journal of Petrology, 43(9): 1673-1705.

Navarro, M. S.; Gomes, C. B.; Girardi, V. A. V., 2008. The direct determination of rare earth elements of microwave oven sample decomposition procedures. Geostandards and Geoanalytical Research, 32(2): 167-180.

Negri, F.A., Oliveira, M.A.F., 2005. Geoquímica e geotermometria dos granulito máficos associados às rochas supracrustais da extremidade meridional do Domínio Socorro, região de São Francisco Xavier, SP. Revista brasileira de Geociências, 35(4): 591-602.

Oliveira, M. A. F., 1973. Petrologia das rochas metamórficas da região de São José do Rio Pardo, SP. Revista Brasileira de Geociências, 3: 256-278.

Oliveira, M. A. F., 1983. As Rochas Granulíticas da Faixa Paraiba do Sul. REVISTA BRASILEIRA DE GEOCIÊNCIAS, SÀO PAULO, 13(2). 84-92.

Oliveira, M. A. F.; ALVES, F. R., 1976. Wollastonita em associações cálcicas de fácies granulito. Revista Brasileira de Geociências, São Paulo, 6: 13-19.

Oliveira, M. A. F.; Hypolito, R., 1978. Ortopiroxênios e clinopiroxênios coexistentes nos granulitos de São José do Rio Pardo, SP. Revista Brasileira de Geociências, 8: 249-261. 
Oliveira, M. A. F.; Ruberti, E., 1979. Granada-cordierita gnaisse do complexo granulíticomigmatítico de São José do Rio Pardo, Caconde, SP: indicações sobre pressão e temperatura de formação. Boletim Mineralógico. Recife, 6: 15-29.

Patiño-Douce, A. E.; Beard, J.S., 1995. Dehydration melting of biotite gneiss and quartz amohibolite from 3 to $15 \mathrm{kbar}$. Journal of Petrology, 36: 707-738.

Patiño-Douce, A.E.; Beard, J.S., 1996. Effects of $P, f\left(\mathrm{O}_{2}\right)$ and $\mathrm{Mg} / \mathrm{Fe}$ ratio on dehydration melting of model metagreyqackes. Journal of Petrology. 37(5): 999-1024.

Pattison, D. R. M., 2003. Petrogenetic significance of orthopyroxene-free garnet + clinopyroxene + plagioclase \pm quartz-bearing metabasites with respect to the amphibolites and granulite facies. Journal of Metamorphic Geology. 21(1): 21-34.

Peternel, R.; Trouw, R. A. J.; Schmitt, R. S., 2005. Interferência entre duas Faixas Móveis Neoproterozóicas: o caso das Faixas Brasília e Ribeira no sudeste do Brasil. Revista Brasileira de Geociências, 35(3): 297-310.

Piwinskii, W.S., 1973b. Experimental studies of granithoids from the central and southern Coast Ranges, California. Tschermaks Mineral. Petrog. Mitt. 20: 107-130.

Powell, R. \& Holland, T. J. B., 1990. Calculated mineral equilibrian in the pelites system KFMASH (K2O-FeO-MgO-Al2O3-SiO2-H2O). American Mineralogist, 75(3-4): 367380.

Powell, R. \& Holland, T. J. B., 1994. Optical geothermometry and geobarometry. Americam Mineralogist, 79(1-2): 120-133.

Powell, R.; Holland, T.; Worley, B., 1998. Calculating phase diagrams involving solid solutios via non-linear equation, with example usins THERMOCALC. Journal of Metamorphic Geology, 16(4): 577-588.

Sawyer, E. W., 2008. Atlas of Migmatites. Ottawa, The American Mineralogist, Specila Publication 9. $371 \mathrm{p}$.

Sawyer, E. W., 2010. Migmatites formed by water-fluxed partial melting of a leucogranodiorite protolith: microstructures in the residual rocks and source of the fluid. Lithos, 116: 273286.

Skjerlie, K. P.; Johnston, A. D., 1996. Vapour-absent melting from 10 to 20 kbar of crustal rocks that contain multiple hydrous phases: implications for anatexis in the deep to very deep continental crust and active continental margins. Journal of Petrology. 37(3): 661-691.

Soto, J.I. \& Soto, V.M. 1995. PTMAFIC: Software package for thermometry, barometry, and activity calculations in mafic rocks using an IBM-compatible computer. Computers \& Geosciences, 21( 5): 619-652.

Spear, F., 1993. Metamorphic phase equilibria and pressure-temperature-time paths. Mineralogical Society of America, Washington, D.C.

Szabó, G. A. J.; Roig, H. L.; Schrank, A.; Choudhuri, A., 1993. Duas faixas lito-estruturais distintas e o limite das províncias Tocantins e Mantiqueira, entre Alpinópolis e Nova Resende (MG). In: Simp. sobre o Cráton do São Francisco-Salvador, BA. Anais. Salvador, SBG: 272-274.

Trouw R. A. J.; Ribeiro A.; Paciullo F. V. P., 1986. Contribuição à geologia da Folha Barbacena 1:250.000. In: Cong. Brasileiro de Geologia, 34, Goiânia, Anais. p 974-986.

Trouw, R. A. J.; Heilbron, M.; Ribeiro, A.; Paciullo, F.; Valeriano, C. M.; Almeida, J. C. H.; Tupinambá, M.; Andreis, R. R., 2000a. The central segment of the Ribeira Belt. In: Cordani, U. G.; Milani, E. J.; Thomaz Filho, A.; Campos, D. A. (eds.) Tectonic Evolution of South America. 31st International Geological Congress. Rio de Janeiro, Brazil. p. 287-310. 
Trouw, R. A. J.; Ribeiro, A.; Paciullo, F.; Heilbron, M. 2000b. Interference between the Neoproterozoic Brasília and Ribeira Belts, with special emphasis on high pressure granulites. In: 31st International Geological Congress. Field Trip Guide. Rio de Janeiro, Brazil. p. 45.

Vasconcellos, A. C. B. C., 1988. O Grupo Andrelândia na região norte de Ouro Fino, MG. Dissertação de Mestrado. IGc-USP, São Paulo, 199 p.

Vielzeuf, D.; Holloway, J. R., 1988. Experimental determination of the fluid-absent melting relations in the pelitic system. Contribution to Mineralogy and Petrology. 98: 257-276.

Vielzeuf, D.; Montel, J. M., 1994. Partial melting of metagreywackes. Part I. Fluid-absente experiments and phase relationships. Contribution to Mineralogy and Petrology. 117: 375-393.

Vielzeuf, D.; Schmidt, M. Q., 2001. Melting relations in hydrous systems revisited: application to metapelitos, metagreywackes and metabasalts. Contribution to Mineralogy and Petrology. 1418: 251-267.

White, R. W. \& Powell, R., 2002. Melt loss and preservation of granulite facies mineral assemblages. Journal of Metamorphic Geology, 20: 621-632.

Zanardo, A., Morales, N., Farias de Oliveira, M.A., Del Lama, E.A., 2006. Tectono-lithologic association of the Alterosa paleo suture zone, southeastern Brazil. Revista UnG Geociências, 5(1): 103-117.

Zanardo; A.; Del Lama, E. A.; Morales, N.; Oliveira, M. A. F., 1996. Geologia da porção limítrofe entre os blocos São Paulo e Brasília. Geociências, São Paulo, 15(n. esp.): 143168. 


\title{
ANEXO 01
}

\author{
Tabela de Pontos
}


Tabela de pontos com as coordenadas, foliação, unidades mapeadas, quantidade de amostras e lâminas

\begin{tabular}{|c|c|c|c|c|c|c|c|c|c|c|c|c|}
\hline PONTO & UTM N & UTM E & $\mathbf{S r}$ & & lex & & $\mathbf{l b}$ & & GRUPO & UNIDADES & AMOSTRAS & LAMINAS \\
\hline ALF01 & 397369 & 7628319 & & & & & & & GUAXUPÉ & GRANULITO & 2 & 4 \\
\hline \multirow{3}{*}{ ALF02 } & \multirow{3}{*}{402444} & \multirow{3}{*}{7634115} & 164 & 35 & & & & & \multirow{3}{*}{ ANDRELÂNDIA } & & \multirow{3}{*}{1} & \\
\hline & & & 200 & 40 & & & & & & & & \\
\hline & & & 183 & 40 & & & & & & & & \\
\hline ALF03 & 410226 & 7640916 & 182 & 38 & 92 & 2 & & & EMBASAMENTO & & & \\
\hline ALF04 & 406686 & 7636533 & 198 & 38 & 214 & 30 & & & ANDRELÂNDIA & & & \\
\hline \multirow{2}{*}{ ALF05 } & \multirow{2}{*}{406084} & \multirow{2}{*}{7634965} & 190 & 50 & 190 & 28 & & & \multirow{2}{*}{ ANDRELÂNDIA } & & \multirow{2}{*}{1} & \\
\hline & & & 200 & 50 & 106 & 0 & & & & & & \\
\hline ALF06 & 401972 & 7626264 & 131 & 50 & 206 & 40 & & & GUAXUPÉ & DIATEXITO & 1 & 1 \\
\hline ALF07 & 402738 & 7623071 & & & & & & & GUAXUPÉ & DIATEXITO & 1 & \\
\hline ALF08 & 402185 & 7611430 & & & & & & & GUAXUPÉ & GRANULITO/DIATEXITO & 2 & \\
\hline ALF09 & 407185 & 7604587 & & & & & & & GUAXUPÉ & GRANITO & 2 & \\
\hline ALF10 & 407716 & 7603763 & & & & & & & GUAXUPÉ & DIATEXITO & 2 & 1 \\
\hline \multirow{2}{*}{ ALF11 } & \multirow{2}{*}{405128} & \multirow{2}{*}{7625671} & 197 & 38 & 110 & 24 & & & \multirow{2}{*}{ GUAXUPÉ } & \multirow{2}{*}{ GRANULITO } & \multirow{2}{*}{7} & \multirow{2}{*}{5} \\
\hline & & & 165 & 26 & & & & & & & & \\
\hline ALF12 & 396725 & 7588674 & & & & & & & GUAXUPÉ & LASCA DE METASSEDIMENTO & & \\
\hline \multirow{5}{*}{ ALFE13 } & \multirow{5}{*}{406891} & \multirow{5}{*}{7636928} & 202 & 70 & & & & & \multirow{5}{*}{ EMBASAMENTO } & & & \\
\hline & & & 192 & 50 & & & 255 & 5 & & & & \\
\hline & & & 186 & 60 & 170 & 41 & 286 & 10 & & & & \\
\hline & & & 188 & 60 & 302 & 33 & 292 & 1 & & & & \\
\hline & & & 192 & 45 & 195 & 65 & & & & & & \\
\hline ALFE14 & 407107 & 7636888 & 190 & 55 & & & & & EMBASAMENTO & & & \\
\hline ALFE15 & 407173 & 7636711 & & & & & & & EMBASAMENTO & & 2 & \\
\hline controle & 407183 & 7636787 & & & & & & & & & & \\
\hline ALFE16 & 407528 & 7636799 & 194 & 55 & 142 & 45 & & & EMBASAMENTO & & & \\
\hline ALFE17 & 407906 & 7636565 & & & & & & & EMBASAMENTO & & & \\
\hline
\end{tabular}


Tabela de pontos com as coordenadas, foliação, unidades mapeadas, quantidade de amostras e lâminas

\begin{tabular}{|c|c|c|c|c|c|c|c|c|c|c|c|}
\hline \multirow{2}{*}{$\begin{array}{l}\text { PONTO } \\
\text { ALFE18 }\end{array}$} & \multirow{2}{*}{$\begin{array}{l}\text { UTM N } \\
408446\end{array}$} & \multirow{2}{*}{\begin{tabular}{|l} 
UTM E \\
7636402
\end{tabular}} & \multicolumn{2}{|c|}{ Sn } & \multicolumn{2}{|c|}{ lext } & \multirow[t]{2}{*}{ lb } & \multirow{2}{*}{$\begin{array}{c}\text { GRUPO } \\
\text { EMBASAMENTO }\end{array}$} & \multirow[t]{2}{*}{ UNIDADES } & \multirow{2}{*}{$\frac{\text { AMOSTRAS }}{2}$} & \multirow[t]{2}{*}{ LAMINAS } \\
\hline & & & 148 & 50 & & & & & & & \\
\hline ALFE19 & 407204 & 7636632 & & & & & & EMBASAMENTO & & & \\
\hline ALFE20 & 406866 & 7636869 & & & & & & EMBASAMENTO & & & \\
\hline ALFE21 & 410404 & 7636044 & 216 & 75 & 325 & 8 & & EMBASAMENTO & & & \\
\hline \multirow{4}{*}{ ALFE22 } & \multirow{4}{*}{410253} & \multirow{4}{*}{7636021} & 205 & 55 & & 185 & 45 & \multirow{4}{*}{ EMBASAMENTO } & & \multirow{4}{*}{1 amostra orientada $\mathrm{Sn}=202 / 65$} & \multirow{4}{*}{1} \\
\hline & & & 206 & 55 & & & & & & & \\
\hline & & & 294 & 71 & 270 & 42 & & & & & \\
\hline & & & & & 179 & 75 & & & & & \\
\hline ALFE23 & 410090 & 7636070 & 201 & 45 & 142 & 35 & & EMBASAMENTO & & 1 & \\
\hline ALFE24 & 409630 & 7635927 & & & & & & EMBASAMENTO & & 7 & 7 \\
\hline ALFE25 & 406841 & 7633646 & 192 & 27 & & & & ANDRELÂNDIA & & & \\
\hline ALFE26 & 396965 & 7629109 & 224 & 55 & & & & GUAXUPÉ & GRANULITO & 5 & 7 \\
\hline \multirow{2}{*}{ ALFE27 } & \multirow{2}{*}{401854} & \multirow{2}{*}{7626296} & 192 & 36 & 117 & 8 & & \multirow{2}{*}{ GUAXUPÉ } & \multirow{2}{*}{ GRANULITO } & & \\
\hline & & & & & 74 & 2 & & & & & \\
\hline ALFE28 & 401811 & 7625900 & & & & & & GUAXUPÉ & GRANULITO & 1 & \\
\hline ALFE29 & 405778 & 7629990 & 190 & 45 & & & & ANDRELÂNDIA & & 1 & \\
\hline ALFE30 & 410939 & 7629928 & & & & & & GUAXUPÉ/ANDRELÂNDIA & GRANULITO & 2 & \\
\hline \multirow{2}{*}{ ALFE31 } & \multirow{2}{*}{413489} & \multirow{2}{*}{7632494} & 194 & 48 & & & & \multirow{2}{*}{ ANDRELÂNDIA } & & \multirow{2}{*}{3} & \multirow{2}{*}{8} \\
\hline & & & 200 & 40 & 124 & 15 & & & & & \\
\hline ALFE32 & 413136 & 7630834 & 212 & 52 & 256 & 10 & & ANDRELÂNDIA & & & \\
\hline ALFE33 & 412568 & 7629787 & 192 & 35 & 84 & 2 & & ANDRELÂNDIA & & & \\
\hline ALFE34 & 410205 & 7626442 & & & & & & GUAXUPÉ & GRANULITO & & \\
\hline ALFE35 & 409848 & 7626593 & & & & & & GUAXUPÉ & GRANULITO & 1 & \\
\hline ALFE36 & 410482 & 7626430 & & & & & & GUAXUPÉ & GRANULITO & 1 & \\
\hline ALFE37 & 410159 & 7626050 & & & & & & GUAXUPÉ & GRANULITO & 2 & 1 \\
\hline ALFE38 & 399414 & 7627626 & 208 & 30 & & & & GUAXUPÉ & LASCA DE METASSEDIMENTO & 1 & \\
\hline
\end{tabular}


Tabela de pontos com as coordenadas, foliação, unidades mapeadas, quantidade de amostras e lâminas

\begin{tabular}{|c|c|c|c|c|c|c|c|c|c|c|c|}
\hline PONTO & UTM N & UTM E & $\mathbf{S}$ & & le & $\mathrm{xt}$ & $\mathbf{l b}$ & GRUPO & UNIDADES & AMOSTRAS & LAMINAS \\
\hline ALFE39 & 399227 & 7626611 & & & & & & GUAXUPÉ & GRANULITO & 1 & \\
\hline ALFE40 & 399333 & 7626487 & 226 & 40 & & & & GUAXUPÉ & GRANULITO & 1 & \\
\hline ALFE41 & 399236 & 7626560 & 205 & 44 & 294 & 10 & & GUAXUPÉ & GRANULITO & & \\
\hline ALFE42 & 399181 & 7626010 & & & & & & GUAXUPÉ & GRANULITO & & \\
\hline ALFE43 & 398832 & 7625151 & & & & & & GUAXUPÉ & GRANULITO & & \\
\hline ALFE44 & 398941 & 7624902 & 213 & 27 & 114 & 8 & & GUAXUPÉ & GRANULITO & 2 & \\
\hline \multirow{4}{*}{ ALFE45 } & \multirow{4}{*}{398999} & \multirow{4}{*}{7627042} & 200 & 30 & 174 & 15 & & \multirow{4}{*}{ GUAXUPÉ } & \multirow{4}{*}{ GRANULITO } & \multirow{4}{*}{26} & \multirow{4}{*}{37} \\
\hline & & & 214 & 50 & 120 & 10 & & & & & \\
\hline & & & 198 & 30 & & & & & & & \\
\hline & & & 215 & 35 & & & & & & & \\
\hline ALFE46 & 403222 & 7637909 & 214 & 54 & 132 & 7 & & EMBASAMENTO & & & \\
\hline ALFE47 & 403242 & 7637759 & 213 & 35 & & & & EMBASAMENTO & & & 2 \\
\hline ALFE48 & 401626 & 7639054 & & & & & & & & 2 & 2 \\
\hline ALFE49 & 402052 & 7638005 & 197 & 48 & 246 & 25 & & EMBASAMENTO & & & \\
\hline ALFE50 & 400732 & 7637959 & 207 & \begin{tabular}{|l|l|}
54 & \\
\end{tabular} & 295 & 14 & & EMBASAMENTO & & & \\
\hline ALFE51 & 399606 & 7638074 & 188 & 55 & & & & EMBASAMENTO & & & \\
\hline ALFE52 & 399509 & 7637723 & & & & & & ANDRELÂNDIA & & & \\
\hline ALFE53 & 398648 & 7636928 & & & & & & ANDRELÂNDIA & & & \\
\hline ALFE54 & 398267 & 7638007 & & & & & & ANDRELÂNDIA & & & \\
\hline ALFE55 & 399513 & 7636497 & & & & & & ANDRELÂNDIA & & & \\
\hline \multirow{2}{*}{ ALFE56 } & \multirow{2}{*}{399831} & \multirow{2}{*}{7635989} & 174 & 47 & 115 & 28 & & \multirow{2}{*}{ ANDRELÂNDIA } & & & \\
\hline & & & 170 & 55 & & & & & & & \\
\hline ALFE57 & 399665 & 7635920 & & & & & & ANDRELÂNDIA & & & \\
\hline ALFE58 & 399543 & 7635940 & 188 & 60 & 125 & 45 & & ANDRELÂNDIA & & & \\
\hline \multirow{3}{*}{ ALFE59 } & \multirow{3}{*}{400690} & \multirow{3}{*}{7635874} & 192 & 32 & & & & \multirow{3}{*}{ ANDRELÂNDIA } & & \multirow{3}{*}{1} & \\
\hline & & & 192 & 38 & & & & & & & \\
\hline & & & 194 & 62 & 284 & 4 & & & & & \\
\hline
\end{tabular}


Tabela de pontos com as coordenadas, foliação, unidades mapeadas, quantidade de amostras e lâminas

\begin{tabular}{|c|c|c|c|c|c|c|c|c|c|c|c|}
\hline PONTO & UTM N & UTM E & \multicolumn{2}{|c|}{ Sn } & \multicolumn{2}{|c|}{ lext } & \multirow[t]{2}{*}{$\mathbf{I b}$} & \multirow{2}{*}{$\begin{array}{c}\text { GRUPO } \\
\text { GUAXUPÉ }\end{array}$} & \multirow{2}{*}{$\begin{array}{c}\text { UNIDADES } \\
\text { GRANULITO }\end{array}$} & \multirow{2}{*}{$\begin{array}{c}\text { AMOSTRAS } \\
2\end{array}$} & \multirow{2}{*}{$\begin{array}{c}\text { LAMINAS } \\
2\end{array}$} \\
\hline ALFE60 & 396929 & 7627808 & & & & & & & & & \\
\hline \multirow{2}{*}{ ALFE61 } & \multirow{2}{*}{397915} & \multirow{2}{*}{7626904} & 204 & 48 & 271 & 10 & & \multirow{2}{*}{ GUAXUPÉ } & \multirow{2}{*}{ GRANULITO } & & \\
\hline & & & 213 & 55 & & & & & & & \\
\hline ALFE62 & 397569 & 7626742 & & & & & & GUAXUPÉ & GRANULITO & 1 & \\
\hline \multirow{2}{*}{ ALFE63 } & \multirow{2}{*}{397150} & \multirow{2}{*}{7626848} & 198 & 32 & 276 & 5 & & \multirow{2}{*}{ GUAXUPÉ } & \multirow{2}{*}{ METATEXITO } & \multirow{2}{*}{2} & \multirow{2}{*}{3} \\
\hline & & & 207 & 27 & & & & & & & \\
\hline ALFE64 & 397873 & 7624502 & & & & & & GUAXUPÉ & GRANULITO & & \\
\hline ALFE65 & 399811 & 7623630 & & & & & & GUAXUPÉ & DIATEXITO & & \\
\hline ALFE66 & 400681 & 7624402 & & & & & & GUAXUPÉ & DIATEXITO & 1 & 1 \\
\hline ALFE67 & 401033 & 7624610 & 219 & 35 & & & & GUAXUPÉ & DIATEXITO & & \\
\hline \multirow{2}{*}{ ALFE68 } & \multirow{2}{*}{406397} & \multirow{2}{*}{7625640} & 188 & 38 & 97 & 2 & & \multirow{2}{*}{ GUAXUPÉ } & \multirow{2}{*}{ GRANULITO } & \multirow{2}{*}{1} & \multirow{2}{*}{1} \\
\hline & & & 187 & 34 & & & & & & & \\
\hline ALFE69 & 404633 & 7625618 & & & & & & GUAXUPÉ & GRANULITO & 1 & 1 \\
\hline \multirow{2}{*}{ ALFE70 } & \multirow{2}{*}{411287} & \multirow{2}{*}{7624153} & 211 & 40 & & & & \multirow{2}{*}{ GUAXUPÉ } & \multirow{2}{*}{ GRANULITO } & & \\
\hline & & & 296 & 8 & & & & & & & \\
\hline & & & 156 & 41 & & & & & & & \\
\hline ALFF71 & 402713 & 7622050 & 154 & 45 & & & & GUAXIPÉ & DIATFXITO & 20 & 17 \\
\hline & 00270 & (102020 & 188 & 25 & & & & & & & \\
\hline & & & 194 & 56 & & & & & & & \\
\hline ALFE72 & 405319 & 7621100 & & & & & & GUAXUPÉ & DIATEXITO & & \\
\hline ALFE73 & 406093 & 7621542 & 118 & 45 & & & & GUAXUPÉ & DIATEXITO & 1 & \\
\hline ALFE74 & 409063 & 7624059 & & & & & & GUAXUPÉ & METATEXITO & & \\
\hline ALFE75 & 408641 & 7624117 & & & & & & GUAXUPÉ & METATEXITO/GRANULITO-FELSICO & & 1 \\
\hline
\end{tabular}


Tabela de pontos com as coordenadas, foliação, unidades mapeadas, quantidade de amostras e lâminas

\begin{tabular}{|c|c|c|c|c|c|c|c|c|c|c|c|}
\hline PONTO & UTM N & UTM E & \multicolumn{2}{|c|}{ Sn } & \multirow[t]{2}{*}{ lext } & \multicolumn{2}{|c|}{ lb } & \multirow{2}{*}{$\frac{\text { GRUPO }}{\text { GUAXUPÉ }}$} & \multirow{2}{*}{$\begin{array}{l}\text { UNIDADES } \\
\text { DIATEXITO }\end{array}$} & \multirow{2}{*}{$\begin{array}{c}\text { AMOSTRAS } \\
1\end{array}$} & \multirow[t]{2}{*}{ LAMINAS } \\
\hline ALFE76 & 408412 & 7621592 & & & & & & & & & \\
\hline ALFE77 & 407007 & 7620345 & & & & & & GUAXUPÉ & DIATEXITO & & \\
\hline ALFE78 & 406765 & 7619864 & & & & & & GUAXUPÉ & METATEXITO & & 1 \\
\hline ALFE79 & 409785 & 7613616 & & & & & & GUAXUPÉ & METATEXITO & & \\
\hline ALFE80 & 398845 & 7613786 & & & & & & GUAXUPÉ & DIATEXITO & & \\
\hline ALFE81 & 398724 & 7613866 & & & & & & GUAXUPÉ & DIATEXITO & 1 & 1 \\
\hline \multirow{2}{*}{ ALFE82 } & \multirow{2}{*}{397953} & \multirow{2}{*}{7614816} & 242 & 55 & & & & \multirow{2}{*}{ GUAXUPÉ } & \multirow{2}{*}{ DIATEXITO } & & \\
\hline & & & 231 & 65 & & & & & & & \\
\hline ALFE83 & 398598 & 7620525 & & & & & & GUAXUPÉ & DIATEXITO & & \\
\hline ALFE84 & & & & & & & & GUAXUPÉ & METATEXITO & & 2 \\
\hline ALFE85 & 398999 & 7627042 & & & & & & GUAXUPÉ & GRANULITO & 11 & 7 \\
\hline ALFE86 & 401965 & 7622275 & 185 & 32 & & & & GUAXUPÉ & DIATEXITO & & \\
\hline \multirow{3}{*}{ ALFE87 } & \multirow{3}{*}{408018} & \multirow{3}{*}{7619402} & 80 & 21 & & 298 & 32 & \multirow{3}{*}{ GUAXUPÉ } & \multirow{3}{*}{ DIATEXITO } & \multirow{3}{*}{2} & \\
\hline & & & 31 & 40 & & & & & & & \\
\hline & & & 18 & 35 & & & & & & & \\
\hline ALFE88 & 407313 & 7618382 & & & & & & GUAXUPÉ & DIATEXITO & & \\
\hline ALFE89 & 408221 & 7619315 & 300 & 12 & & 128 & 7 & GUAXUPÉ & DIATEXITO & & \\
\hline \multirow{2}{*}{ ALFE90 } & \multirow{2}{*}{408224} & \multirow{2}{*}{7619397} & 24 & 5 & & & & \multirow{2}{*}{ GUAXUPÉ } & \multirow{2}{*}{ DIATEXITO } & & \\
\hline & & & 115 & 10 & & & & & & & \\
\hline ALFE91 & 408248 & 7619625 & & & & & & GUAXUPÉ & DIATEXITO & & \\
\hline
\end{tabular}


ANEXO 02

Química Mineral 


\section{Amostra ALFE11a - Ortopiroxênio}

\begin{tabular}{|c|c|c|c|c|c|c|c|c|c|c|c|c|c|c|c|c|c|c|c|c|c|}
\hline Sample & 101 & 102 & 103 & 104 & 105 & 106 & 201 & 202 & 203 & 204 & 205 & 206 & 207 & 208 & 209 & 210 & 301 & 302 & 303 & 304 & 305 \\
\hline Min & onx & opx & opx & opx & opx & opx & opx & opx & opx & opx & opx & opx & opx & opx & opx & opx & opx & opx & opx & opx & opx \\
\hline $\mathrm{SiO}_{2}$ & 50,36 & 51,4 & 50,52 & 50,78 & 51,03 & 39,06 & 50,85 & 50,3 & 50,85 & 50,98 & 51,01 & 50,66 & 50,78 & 51,11 & 51,15 & 51,29 & 50,86 & 50,16 & 50,52 & 51,03 & 51,03 \\
\hline $\mathrm{TiO}_{2}$ & 0,05 & 0,07 & 0,09 & 0,09 & 0,1 & 0,01 & 0,09 & 0,09 & 0,09 & 0,07 & 0,07 & 0,09 & 0,09 & 0,07 & 0,08 & 0,06 & 0,05 & 0,1 & 0,09 & 0,09 & 0,06 \\
\hline $\mathrm{Al}_{2} \mathrm{O}_{3}$ & 2,17 & 1,6 & 2,29 & 2,05 & 2,16 & 3,58 & 2 & 2,35 & 2,31 & 2,03 & 1,95 & 1,97 & 2,19 & 1,89 & 1,86 & 1,75 & 2,37 & 2,4 & 2,26 & 2,14 & 1,78 \\
\hline $\mathrm{Cr}_{2} \mathrm{O}_{3}$ & 0 & 0 & 0 & 0 & 0 & 0 & 0 & 0 & 0 & 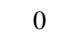 & 0 & 0 & 0 & 0 & 0 & 0 & 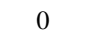 & 0 & 0 & 0 & 0 \\
\hline $\mathrm{Fe}_{2} \mathrm{O}_{3}$ & 2,88 & 0,76 & 2 & 1,07 & 1,23 & 0 & 1,18 & 2,04 & 1,45 & 1,1 & 2,15 & 1,92 & 1,18 & 0,03 & 0,58 & 1,65 & 1,03 & 1,89 & 1,37 & 0,74 & 0,34 \\
\hline $\mathrm{FeO}$ & 24,88 & 26,38 & 25,73 & 26,12 & 26,41 & 18,64 & 25,31 & 24,92 & 25,71 & 25,39 & 25,08 & 24,62 & 25,5 & 25,88 & 25,56 & 25,4 & 25,77 & 25,22 & 25,16 & 26,15 & 26,17 \\
\hline $\mathrm{MnO}$ & 0,59 & 0,6 & 0,57 & 0,58 & 0,58 & 0,26 & 0,54 & 0,55 & 0,47 & 0,34 & 0,55 & 0,51 & 0,58 & 0,55 & 0,6 & 0,59 & 0,42 & 0,65 & 0,61 & 0,62 & 0,43 \\
\hline $\mathrm{MgO}$ & 19,14 & 18,94 & 18,82 & 18,72 & 18,74 & 10,76 & 19,28 & 19,06 & 18,94 & 19,36 & 19,52 & 19,52 & 19,03 & 19,03 & 19,27 & 19,48 & 19,11 & 18,81 & 18,98 & 18,87 & 18,98 \\
\hline $\mathrm{CaO}$ & 0,38 & 0,46 & 0,46 & 0,48 & 0,49 & 1,51 & 0,5 & 0,56 & 0,56 & 0,45 & 0,49 & 0,5 & 0,56 & 0,55 & 0,53 & 0,46 & 0,46 & 0,52 & 0,55 & 0,49 & 0,45 \\
\hline $\mathrm{Na} 2 \mathrm{O}$ & 0,04 & 0,04 & 0,01 & 0,02 & 0,02 & 0,09 & 0,01 & 0,01 & 0,05 & 0, & 0 & 0,02 & 0,02 & 0,02 & 0,01 & 0,02 & . & 0 & 0,04 & 0,01 & 0,02 \\
\hline $\mathrm{K}_{2} \mathrm{O}$ & 0 & 0 & 0 & 0 & 0 & 0 & 0 & 0 & 0 & 0 & 0 & 0 & 0 & 0 & 0 & 0 & 0 & 0 & 0 & 0 & 0 \\
\hline Totals & 00,49 & 100,26 & 100,5 & 99,92 & 100,77 & 73,92 & 99,75 & 87 & 43 & 77 & 100,81 & 99,81 & 99,94 & 99,13 & 99,63 & 100,7 & 0,07 & 99,75 & 99,58 & 00,15 & 99,25 \\
\hline Oxygen & 6 & 6 & 6 & 6 & 6 & 6 & 6 & 6 & 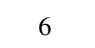 & 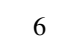 & 6 & 6 & 6 & 6 & 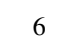 & 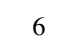 & 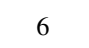 & 6 & 6 & 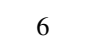 & 6 \\
\hline $\mathrm{Si}$ & 1,91 & 1,953 & 1,918 & 1,937 & 1,932 & 1,986 & 1,936 & 1,916 & 1,927 & 1,938 & 1,924 & 1,927 & 1,932 & 1,956 & 1,948 & 1,937 & 1,931 & 1,916 & 1,928 & 1,939 & 1,954 \\
\hline $\mathrm{Ti}$ & 0,001 & 0,002 & 0,003 & 0,003 & 0,003 & 0,001 & 0,002 & 0,002 & 0,003 & 0,002 & 0,002 & 0,003 & 0,003 & 0,002 & 0,002 & 0,002 & 0,001 & 0,003 & 0,002 & 0,003 & 0,002 \\
\hline $\mathrm{Al}$ & 0,097 & 0,072 & 0,102 & 0,092 & 0,097 & 0,214 & 0,09 & 0,105 & 0,103 & 0,091 & 0,087 & 0,088 & 0,098 & 0,085 & 0,083 & 0,078 & 0,106 & 0,108 & 0,102 & 0,096 & 0,08 \\
\hline $\mathrm{Cr}$ & 0 & 0 & . & . & 0 & 0 & 0 & 0 & 0 & 0 & 0 & 0 & 0 & 0 & 0 & 0 & 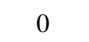 & 0 & 0 & 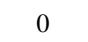 & 0 \\
\hline $\mathrm{Fe} 3$ & 0,082 & 0,022 & 0,057 & 0,031 & 0,035 & 0 & 0,034 & 0,058 & 0,041 & 0,031 & 0,061 & 0,055 & 0,034 & 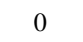 & 0,017 & 0,047 & 0,029 & 0,054 & 0,039 & 0,021 & 0,01 \\
\hline $\mathrm{Fe} 2$ & 0,79 & 0,838 & 0,817 & 0,833 & 0,836 & 0,793 & 0,806 & 0,794 & 0,815 & 0,808 & 0,791 & 0,783 & 0,811 & 0,829 & 0,814 & 0,802 & 0,818 & 0,806 & 0,803 & 0,831 & 0,838 \\
\hline $\mathrm{Mn}$ & 0,019 & 0,019 & 0,018 & 0,019 & 0,019 & 0,011 & 0,017 & 0,018 & 0,015 & 0,011 & 0,018 & 0,017 & 0,019 & 0,018 & 0,019 & 0,019 & 0,013 & 0,021 & 0,02 & 0,02 & 0,014 \\
\hline $\mathrm{Mg}$ & 1,082 & 1,072 & 1,065 & 1,064 & 1,058 & 0,815 & 1,094 & 1,082 & 1,07 & 1,097 & 1,098 & 1,106 & 1,079 & 1,085 & 1,094 & 1,096 & 1,081 & 1,071 & 1,08 & 1,069 & 1,083 \\
\hline $\mathrm{Ca}$ & 0,015 & 0,019 & 0,019 & 0,02 & 0,02 & 0,082 & 0,02 & 0,023 & 0,023 & 0,018 & 0,02 & 0,02 & 0,023 & 0,023 & 0,021 & 0,019 & 0,019 & 0,021 & 0,022 & 0,02 & 0,018 \\
\hline $\mathrm{Na}$ & 0,003 & 0,003 & 0,001 & 0,002 & 0,001 & 0,009 & 0,001 & 0,001 & 0,004 & 0,003 & 0 & 0,001 & 0,001 & 0,001 & 0,001 & 0,001 & 0 & 0 & 0,003 & 0,001 & 0,001 \\
\hline K & 0 & 0 & 0 & 0 & 0 & 0 & 0 & 0 & 0 & 0 & 0 & 0 & 0 & 0 & 0 & 0 & 0 & 0 & 0 & 0 & 0 \\
\hline Sum & 4 & 4 & 4 & 4 & 4 & 3,911 & 4 & 4 & 4 & 4 & 4 & 4 & 4 & 4 & 4 & 4 & 4 & 4 & 4 & 4 & 4 \\
\hline
\end{tabular}


Amostra ALFE11a - Plagioclásio

\begin{tabular}{|c|c|c|c|c|c|c|c|c|c|c|c|c|c|c|c|c|c|c|c|c|c|c|}
\hline Sample & 01_01 & 01_02 & 01_03 & $02 \_01$ & 02_02 & 02_03 & 04_01 & $04 \_02$ & 04_03 & 05_01 & 05_02 & 05_03 & 06_01 & 06_02 & 06_03 & 06_04 & 07_01 & 07_02 & 07_03 & 08_01 & 08_02 & 08_03 \\
\hline Min & fsp & fsp & fsp & fsp & fsp & fsp & fsp & fsp & fsp & fsp & fsp & fsp & fsp & fsp & fsp & fsp & fsp & fsp & fsp & $\mathrm{fsp}$ & fsp & fsp \\
\hline $\mathrm{SiO} 2$ & 62,95 & 62,68 & 61,53 & 61,64 & 63,28 & 62,38 & 62,06 & 62,87 & 62,01 & 62,68 & 63,06 & 62,57 & 62,41 & 62,54 & 62,85 & 62,33 & 63,44 & 62,76 & 61,69 & 65,14 & 65,04 & 65,56 \\
\hline $\mathrm{TiO} 2$ & 0 & 0 & 0 & 0 & 0 & 0 & 0 & 0 & 0 & 0 & 0 & 0 & 0 & 0 & 0 & 0 & 0 & 0 & 0 & 0 & 0 & 0 \\
\hline $\mathrm{A} 12 \mathrm{O} 3$ & 23,07 & 23,08 & 23,62 & 23,57 & 23,23 & 23,2 & 23,64 & 23,35 & 23,24 & 23,41 & 23,24 & 22,88 & 23,5 & 23,06 & 23,07 & 23,53 & 23,38 & 23,33 & 23,45 & 18 & 18,04 & 17,91 \\
\hline $\mathrm{Cr} 2 \mathrm{O} 3$ & 0 & 0 & 0 & 0 & 0 & 0 & 0 & 0 & 0 & 0 & 0 & 0 & 0 & 0 & 0 & 0 & 0 & 0 & 0 & 0 & 0 & 0 \\
\hline $\mathrm{Fe} 2 \mathrm{O} 3$ & 0 & 0 & 0 & 0 & 0 & 0 & 0 & 0 & 0 & 0 & 0 & 0 & 0 & 0 & 0 & 0 & 0 & 0 & 0 & 0 & 0 & 0 \\
\hline $\mathrm{FeO}$ & 0 & 0 & 0 & 0 & 0 & 0 & 0 & 0 & 0 & 0 & 0 & 0 & 0 & 0 & 0 & 0 & 0 & 0 & 0 & 0 & 0 & 0 \\
\hline $\mathrm{MnO}$ & 0 & 0 & 0 & 0 & 0 & 0 & 0 & 0 & 0 & 0 & 0 & 0 & 0 & 0 & 0 & 0 & 0 & 0 & 0 & 0 & 0 & 0 \\
\hline $\mathrm{MgO}$ & 0 & 0 & 0 & 0 & 0 & 0 & 0 & 0 & 0 & 0 & 0 & 0 & 0 & 0 & 0 & 0 & 0 & 0 & 0 & 0 & 0 & 0 \\
\hline $\mathrm{CaO}$ & 5,68 & 5,72 & 6,12 & 6,05 & 5,84 & 5,73 & 6,25 & 5,76 & 5,94 & 5,96 & 5,73 & 6,07 & 6,18 & 5,77 & 5,79 & 6,09 & 6,16 & 5,92 & 6,27 & 0,13 & 0,12 & 0,21 \\
\hline $\mathrm{Na} 2 \mathrm{O}$ & 7,76 & 7,78 & 7,6 & 7,52 & 7,64 & 7,58 & 7,46 & 7,36 & 7,47 & 7,6 & 7,73 & 7,58 & 7,58 & 7,72 & 7,66 & 7,59 & 7,44 & 7,71 & 7,46 & 0,82 & 1,08 & 1,2 \\
\hline $\mathrm{K} 2 \mathrm{O}$ & 0,42 & 0,48 & 0,32 & 0,33 & 0,4 & 0,33 & 0,74 & 0,91 & 0,7 & 0,65 & 0,56 & 0,6 & 0,36 & 0,53 & 0,6 & 0,29 & 0,39 & 0,46 & 0,36 & 17,69 & 17,38 & 16,96 \\
\hline Totals & 99,88 & 99,72 & 99,2 & 99,11 & 100,38 & 99,22 & 100,15 & 100,25 & 99,37 & 100,3 & 100,33 & 99,7 & 100,01 & 99,62 & 99,97 & 99,84 & 100,81 & 100,17 & 99,24 & 101,77 & 101,66 & 101,84 \\
\hline Oxygens & 8 & 8 & 8 & 8 & 8 & 8 & 8 & 8 & 8 & 8 & 8 & 8 & 8 & 8 & 8 & 8 & 8 & 8 & 8 & 8 & 8 & 8 \\
\hline $\mathrm{Si}$ & 2,789 & 2,783 & 2,75 & 2,752 & 2,788 & 2,78 & 2,75 & 2,779 & 2,767 & 2,771 & 2,783 & 2,783 & 2,764 & 2,781 & 2,785 & 2,764 & 2,784 & 2,775 & 2,755 & 2,988 & 2,986 & 2,997 \\
\hline $\mathrm{Ti}$ & 0 & 0 & 0 & 0 & 0 & 0 & 0 & 0 & 0 & 0 & 0 & 0 & 0 & 0 & 0 & 0 & 0 & 0 & 0 & 0 & 0 & 0 \\
\hline $\mathrm{Al}$ & 1,205 & 1,208 & 1,245 & 1,241 & 1,207 & 1,219 & 1,235 & 1,217 & 1,223 & 1,22 & 1,209 & 1,2 & 1,227 & 1,209 & 1,205 & 1,23 & 1,21 & 1,216 & 1,235 & 0,974 & 0,977 & 0,965 \\
\hline $\mathrm{Cr}$ & 0 & 0 & 0 & 0 & 0 & 0 & 0 & 0 & 0 & 0 & 0 & 0 & 0 & 0 & 0 & 0 & 0 & 0 & 0 & 0 & 0 & 0 \\
\hline $\mathrm{Fe} 3$ & 0 & 0,002 & 0 & 0,006 & 0,001 & 0 & 0,006 & 0,002 & 0,004 & 0,001 & 0,002 & 0 & 0,001 & 0,001 & 0,002 & 0,001 & 0,001 & 0,001 & 0,003 & 0,002 & 0 & 0,001 \\
\hline $\mathrm{Fe} 2$ & 0 & 0 & 0 & 0 & 0 & 0 & 0 & 0 & 0 & 0 & 0 & 0 & 0 & 0 & 0 & 0 & 0 & 0 & 0 & 0 & 0 & 0 \\
\hline $\mathrm{Mn}$ & 0 & 0 & 0 & 0 & 0 & 0 & 0 & 0 & 0 & 0 & 0 & 0 & 0 & 0 & 0 & 0 & 0 & 0 & 0 & 0 & 0 & 0 \\
\hline $\mathrm{Mg}$ & 0 & 0 & 0 & 0 & 0 & 0 & 0 & 0 & 0 & 0 & 0 & 0 & 0 & 0 & 0 & 0 & 0 & 0 & 0 & 0 & 0 & 0 \\
\hline $\mathrm{Ca}$ & 0,27 & 0,272 & 0,293 & 0,289 & 0,276 & 0,274 & 0,297 & 0,273 & 0,284 & 0,283 & 0,271 & 0,289 & 0,293 & 0,275 & 0,275 & 0,29 & 0,29 & 0,28 & 0,3 & 0,006 & 0,006 & 0,01 \\
\hline $\mathrm{Na}$ & 0,666 & 0,669 & 0,659 & 0,651 & 0,652 & 0,655 & 0,641 & 0,631 & 0,647 & 0,651 & 0,661 & 0,654 & 0,651 & 0,666 & 0,658 & 0,653 & 0,633 & 0,661 & 0,646 & 0,073 & 0,096 & 0,106 \\
\hline K & 0,024 & 0,027 & 0,018 & 0,019 & 0,022 & 0,019 & 0,042 & 0,051 & 0,04 & 0,037 & 0,032 & 0,034 & 0,02 & 0,03 & 0,034 & 0,016 & 0,022 & 0,026 & 0,02 & 1,035 & 1,018 & 0,989 \\
\hline Sum & 4,954 & 4,961 & 4,966 & 4,958 & 4,946 & 4,947 & 4,97 & 4,953 & 4,963 & 4,962 & 4,958 & 4,961 & 4,957 & 4,962 & 4,958 & 4,955 & 4,939 & 4,96 & 4,959 & 5,079 & 5,083 & 5,069 \\
\hline
\end{tabular}


Amostra ALFE11a - Plagioclásio

\begin{tabular}{|c|c|c|c|c|c|c|c|c|c|c|c|c|c|c|c|c|c|c|c|c|c|c|}
\hline Sample & 101 & 102 & 103 & 201 & 202 & 203 & 401 & 402 & 403 & 501 & 502 & 503 & 601 & 602 & 603 & 604 & 701 & 702 & 703 & 801 & 802 & 803 \\
\hline Min & fsp & fsp & fsp & fsp & fsp & fsp & fsp & fsp & fsp & fsp & fsp & fsp & fsp & fsp & fsp & fsp & fsp & fsp & fsp & fsp & fsp & fsp \\
\hline $\mathrm{SiO} 2$ & 62,95 & 62,68 & 61,53 & 61,64 & 63,28 & 62,38 & 62,06 & 62,87 & 62,01 & 62,68 & 63,06 & 62,57 & 62,41 & 62,54 & 62,85 & 62,33 & 63,44 & 62,76 & 61,69 & 65,14 & 65,04 & 65,56 \\
\hline $\mathrm{TiO} 2$ & 0 & 0 & 0 & 0 & 0 & 0 & 0 & 0 & 0 & 0 & 0 & 0 & 0 & 0 & 0 & 0 & 0 & 0 & 0 & 0 & 0 & 0 \\
\hline $\mathrm{Al} 2 \mathrm{O} 3$ & 23,07 & 23,08 & 23,62 & 23,57 & 23,23 & 23,2 & 23,64 & 23,35 & 23,24 & 23,41 & 23,24 & 22,88 & 23,5 & 23,06 & 23,07 & 23,53 & 23,38 & 23,33 & 23,45 & 18 & 18,04 & 17,91 \\
\hline $\mathrm{Cr} 2 \mathrm{O} 3$ & 0 & 0 & 0 & 0 & 0 & 0 & 0 & 0 & 0 & 0 & 0 & 0 & 0 & 0 & 0 & 0 & 0 & 0 & 0 & 0 & 0 & 0 \\
\hline $\mathrm{Fe} 2 \mathrm{O} 3$ & 0 & 0 & 0 & 0 & 0 & 0 & 0 & 0 & 0 & 0 & 0 & 0 & 0 & 0 & 0 & 0 & 0 & 0 & 0 & 0 & 0 & 0 \\
\hline $\mathrm{FeO}$ & 0 & 0 & 0 & 0 & 0 & 0 & 0 & 0 & 0 & 0 & 0 & 0 & 0 & 0 & 0 & 0 & 0 & 0 & 0 & 0 & 0 & 0 \\
\hline $\mathrm{MnO}$ & 0 & 0 & 0 & 0 & 0 & 0 & 0 & 0 & 0 & 0 & 0 & 0 & 0 & 0 & 0 & 0 & 0 & 0 & 0 & 0 & 0 & 0 \\
\hline $\mathrm{MgO}$ & 0 & 0 & 0 & 0 & 0 & 0 & 0 & 0 & 0 & 0 & 0 & 0 & 0 & 0 & 0 & 0 & 0 & 0 & 0 & 0 & 0 & 0 \\
\hline $\mathrm{CaO}$ & 5,68 & 5,72 & 6,12 & 6,05 & 5,84 & 5,73 & 6,25 & 5,76 & 5,94 & 5,96 & 5,73 & 6,07 & 6,18 & 5,77 & 5,79 & 6,09 & 6,16 & 5,92 & 6,27 & 0,13 & 0,12 & 0,21 \\
\hline $\mathrm{Na} 2 \mathrm{O}$ & 7,76 & 7,78 & 7,6 & 7,52 & 7,64 & 7,58 & 7,46 & 7,36 & 7,47 & 7,6 & 7,73 & 7,58 & 7,58 & 7,72 & 7,66 & 7,59 & 7,44 & 7,71 & 7,46 & 0,82 & 1,08 & 1,2 \\
\hline $\mathrm{K} 2 \mathrm{O}$ & 0,42 & 0,48 & 0,32 & 0,33 & 0,4 & 0,33 & 0,74 & 0,91 & 0,7 & 0,65 & 0,56 & 0,6 & 0,36 & 0,53 & 0,6 & 0,29 & 0,39 & 0,46 & 0,36 & 17,69 & 17,38 & 16,96 \\
\hline Totals & 99,88 & 99,72 & 99,2 & 99,11 & 100,38 & 99,22 & 100,15 & 100,25 & 99,37 & 100,3 & 100,33 & 99,7 & 100,01 & 99,62 & 99,97 & 99,84 & 100,81 & 100,17 & 99,24 & 101,77 & 101,66 & 101,84 \\
\hline Oxygens & 8 & 8 & 8 & 8 & 8 & 8 & 8 & 8 & 8 & 8 & 8 & 8 & 8 & 8 & 8 & 8 & 8 & 8 & 8 & 8 & 8 & 8 \\
\hline $\mathrm{Si}$ & 2,789 & 2,783 & 2,75 & 2,752 & 2,788 & 2,78 & 2,75 & 2,779 & 2,767 & 2,771 & 2,783 & 2,783 & 2,764 & 2,781 & 2,785 & 2,764 & 2,784 & 2,775 & 2,755 & 2,988 & 2,986 & 2,997 \\
\hline $\mathrm{Ti}$ & 0 & 0 & 0 & 0 & 0 & 0 & 0 & 0 & 0 & 0 & 0 & 0 & 0 & 0 & 0 & 0 & 0 & 0 & 0 & 0 & 0 & 0 \\
\hline $\mathrm{Al}$ & 1,205 & 1,208 & 1,245 & 1,241 & 1,207 & 1,219 & 1,235 & 1,217 & 1,223 & 1,22 & 1,209 & 1,2 & 1,227 & 1,209 & 1,205 & 1,23 & 1,21 & 1,216 & 1,235 & 0,974 & 0,977 & 0,965 \\
\hline $\mathrm{Cr}$ & 0 & 0 & 0 & 0 & 0 & 0 & 0 & 0 & 0 & 0 & 0 & 0 & 0 & 0 & 0 & 0 & 0 & 0 & 0 & 0 & 0 & 0 \\
\hline $\mathrm{Fe} 3$ & 0 & 0,002 & 0 & 0,006 & 0,001 & 0 & 0,006 & 0,002 & 0,004 & 0,001 & 0,002 & 0 & 0,001 & 0,001 & 0,002 & 0,001 & 0,001 & 0,001 & 0,003 & 0,002 & 0 & 0,001 \\
\hline $\mathrm{Fe} 2$ & 0 & 0 & 0 & 0 & 0 & 0 & 0 & 0 & 0 & 0 & 0 & 0 & 0 & 0 & 0 & 0 & 0 & 0 & 0 & 0 & 0 & 0 \\
\hline $\mathrm{Mn}$ & 0 & 0 & 0 & 0 & 0 & 0 & 0 & 0 & 0 & 0 & 0 & 0 & 0 & 0 & 0 & 0 & 0 & 0 & 0 & 0 & 0 & 0 \\
\hline $\mathrm{Mg}$ & 0 & 0 & 0 & 0 & 0 & 0 & 0 & 0 & 0 & 0 & 0 & 0 & 0 & 0 & 0 & 0 & 0 & 0 & 0 & 0 & 0 & 0 \\
\hline $\mathrm{Ca}$ & 0,27 & 0,272 & 0,293 & 0,289 & 0,276 & 0,274 & 0,297 & 0,273 & 0,284 & 0,283 & 0,271 & 0,289 & 0,293 & 0,275 & 0,275 & 0,29 & 0,29 & 0,28 & 0,3 & 0,006 & 0,006 & 0,01 \\
\hline $\mathrm{Na}$ & 0,666 & 0,669 & 0,659 & 0,651 & 0,652 & 0,655 & 0,641 & 0,631 & 0,647 & 0,651 & 0,661 & 0,654 & 0,651 & 0,666 & 0,658 & 0,653 & 0,633 & 0,661 & 0,646 & 0,073 & 0,096 & 0,106 \\
\hline $\mathrm{K}$ & 0,024 & 0,027 & 0,018 & 0,019 & 0,022 & 0,019 & 0,042 & 0,051 & 0,04 & 0,037 & 0,032 & 0,034 & 0,02 & 0,03 & 0,034 & 0,016 & 0,022 & 0,026 & 0,02 & 1,035 & 1,018 & 0,989 \\
\hline Sum & 4,954 & 4,961 & 4,966 & 4,958 & 4,946 & 4,947 & 4,97 & 4,953 & 4,963 & 4,962 & 4,958 & 4,961 & 4,957 & 4,962 & 4,958 & 4,955 & 4,939 & 4,96 & 4,959 & 5,079 & 5,083 & 5,069 \\
\hline
\end{tabular}


Amostra ALFE24b - Biotita

\begin{tabular}{|c|c|c|c|c|c|c|c|c|c|c|c|c|c|c|c|c|c|}
\hline Sample & 101 & 102 & 103 & 201 & 202 & 203 & 204 & 205 & 301 & 302 & 303 & 304 & 305 & 401 & 402 & 403 & 404 \\
\hline Min & bi & bi & bi & bi & bi & bi & bi & bi & bi & bi & bi & bi & bi & bi & bi & bi & bi \\
\hline $\mathrm{SiO} 2$ & 34,56 & 34,73 & 52,6 & 34,82 & 34,03 & 34,7 & 34,66 & 34,69 & 33,82 & 34,58 & 34,55 & 35,03 & 35,55 & 40,64 & 40,36 & 40,05 & 39,76 \\
\hline $\mathrm{TiO} 2$ & 2,42 & 2,3 & 1,67 & 2,8 & 3,11 & 3,23 & 3,79 & 3,67 & 1,97 & 2,38 & 2,92 & 3,34 & 3,42 & 1,34 & 1,44 & 1,32 & 1,28 \\
\hline $\mathrm{Al} 2 \mathrm{O} 3$ & 16,26 & 16,46 & 12,48 & 15,76 & 15,1 & 16,02 & 15,28 & 15,02 & 16,88 & 16,46 & 16,13 & 15,55 & 15,82 & 12,62 & 12,5 & 12,43 & 13,04 \\
\hline $\mathrm{Cr} 2 \mathrm{O} 3$ & 0 & 0 & 0 & 0 & 0 & 0 & 0 & 0 & 0 & 0 & 0 & 0 & 0 & 0 & 0 & 0 & 0 \\
\hline $\mathrm{Fe} 2 \mathrm{O} 3$ & 0 & 0 & 0 & 0 & 0 & 0 & 0 & 0 & 0 & 0 & 0 & 0 & 0 & 0 & 0 & 0 & 0 \\
\hline $\mathrm{FeO}$ & 33,15 & 30,99 & 23,82 & 32,79 & 34,02 & 33,23 & 32,77 & 32,8 & 33,36 & 32,28 & 32,83 & 33 & 33,09 & 29,09 & 29,64 & 29,77 & 29,23 \\
\hline $\mathrm{MnO}$ & 0 & 0 & 0 & 0 & 0 & 0 & 0 & 0 & 0 & 0 & 0 & 0 & 0 & 0 & 0 & 0 & 0 \\
\hline $\mathrm{MgO}$ & 0,84 & 0,82 & 0,58 & 0,96 & 0,86 & 0,85 & 0,88 & 0,91 & 0,86 & 0,87 & 0,84 & 0,86 & 0,87 & 0,4 & 0,58 & 0,56 & 0,47 \\
\hline $\mathrm{CaO}$ & 0 & 0 & 0 & 0 & 0 & 0 & 0 & 0 & 0 & 0 & 0 & 0 & 0 & 0 & 0 & 0 & 0 \\
\hline $\mathrm{Na} 2 \mathrm{O}$ & 0 & 0 & 0 & 0 & 0 & 0 & 0 & 0 & 0 & 0 & 0 & 0 & 0 & 0 & 0 & 0 & 0 \\
\hline $\mathrm{K} 2 \mathrm{O}$ & 9,11 & 9,29 & 6,69 & 9,19 & 8,59 & 8,74 & 8,82 & 8,66 & 9,23 & 9,36 & 9,51 & 9,59 & 9,6 & 2,2 & 2,21 & 2,23 & 2,24 \\
\hline Totals & 96,34 & 94,6 & 97,83 & 96,32 & 95,71 & 96,77 & 96,2 & 95,75 & 96,11 & 95,94 & 96,78 & 97,36 & 98,36 & 86,29 & 86,73 & 86,37 & 86,02 \\
\hline Oxygens & 11 & 11 & 11 & 11 & 11 & 11 & 11 & 11 & 11 & 11 & 11 & 11 & 11 & 11 & 11 & 11 & 11 \\
\hline $\mathrm{Si}$ & 2,789 & 2,828 & 3,737 & 2,807 & 2,78 & 2,782 & 2,795 & 2,811 & 2,745 & 2,795 & 2,778 & 2,801 & 2,807 & 3,388 & 3,362 & 3,357 & 3,337 \\
\hline $\mathrm{Ti}$ & 0,147 & 0,141 & 0,089 & 0,17 & 0,191 & 0,194 & 0,23 & 0,223 & 0,12 & 0,145 & 0,177 & 0,201 & 0,203 & 0,084 & 0,09 & 0,083 & 0,081 \\
\hline $\mathrm{Al}$ & 1,547 & 1,58 & 1,045 & 1,498 & 1,454 & 1,514 & 1,453 & 1,435 & 1,615 & 1,568 & 1,529 & 1,466 & 1,473 & 1,241 & 1,228 & 1,228 & 1,29 \\
\hline $\mathrm{Cr}$ & 0 & 0 & 0 & 0 & 0 & 0 & 0 & 0 & 0 & 0 & 0 & 0 & 0 & 0 & 0 & 0 & 0 \\
\hline $\mathrm{Fe} 3$ & 0 & 0 & 0 & 0 & 0 & 0 & 0 & 0 & 0 & 0 & 0 & 0 & 0 & 0 & 0 & 0 & 0 \\
\hline $\mathrm{Fe} 2$ & 2,237 & 2,11 & 1,415 & 2,211 & 2,324 & 2,228 & 2,211 & 2,223 & 2,265 & 2,181 & 2,208 & 2,207 & 2,185 & 2,028 & 2,065 & 2,087 & 2,051 \\
\hline $\mathrm{Mn}$ & 0 & 0 & 0 & 0 & 0 & 0 & 0 & 0 & 0 & 0 & 0 & 0 & 0 & 0 & 0 & 0 & 0 \\
\hline $\mathrm{Mg}$ & 0,102 & 0,1 & 0,061 & 0,115 & 0,105 & 0,102 & 0,106 & 0,11 & 0,104 & 0,105 & 0,101 & 0,102 & 0,102 & 0,049 & 0,072 & 0,07 & 0,059 \\
\hline $\mathrm{Ca}$ & 0 & 0 & 0 & 0 & 0 & 0 & 0 & 0 & 0 & 0 & 0 & 0 & 0 & 0 & 0 & 0 & 0 \\
\hline $\mathrm{Na}$ & 0 & 0 & 0 & 0 & 0 & 0 & 0 & 0 & 0 & 0 & 0 & 0 & 0 & 0 & 0 & 0 & 0 \\
\hline $\mathrm{K}$ & 0,938 & 0,965 & 0,606 & 0,945 & 0,895 & 0,894 & 0,908 & 0,896 & 0,956 & 0,965 & 0,976 & 0,978 & 0,967 & 0,234 & 0,235 & 0,238 & 0,24 \\
\hline Sum & 7,761 & 7,725 & 6,955 & 7,747 & 7,75 & 7,714 & 7,703 & 7,697 & 7,805 & 7,76 & 7,769 & 7,755 & 7,738 & 7,025 & 7,052 & 7,065 & 7,058 \\
\hline
\end{tabular}


Amostra ALFE24b - Feldspato Potássico

\begin{tabular}{|c|c|c|c|c|c|c|c|c|c|c|c|c|c|c|c|c|c|c|c|c|c|c|}
\hline Sample & 101 & 102 & 103 & 104 & 105 & 201 & 202 & 203 & 204 & 301 & 302 & 303 & 304 & 401 & 402 & 403 & 404 & 501 & 502 & 503 & 504 & 505 \\
\hline Min & fsp & fsp & fsp & fsp & fsp & fsp & fsp & fsp & fsp & fsp & fsp & fsp & fsp & fsp & fsp & fsp & fsp & fsp & fsp & fsp & fsp & fsp \\
\hline $\mathrm{SiO} 2$ & 63,54 & 63,78 & 63,29 & 63,46 & 64,29 & 63,52 & 64,15 & 63,83 & 63,84 & 63,7 & 64,13 & 64,25 & 64,31 & 85,39 & 64,36 & 64,1 & 64,51 & 64,17 & 64,18 & 63,95 & 63,65 & 62,45 \\
\hline $\mathrm{TiO} 2$ & 0 & 0 & 0 & 0 & 0 & 0 & 0 & 0 & 0 & 0 & 0 & 0 & 0 & 0 & 0 & 0 & 0 & 0 & 0 & 0 & 0 & 0 \\
\hline $\mathrm{A} 12 \mathrm{O} 3$ & 17,64 & 17,68 & 17,64 & 17,77 & 17,56 & 17,8 & 17,69 & 17,72 & 17,61 & 17,63 & 17,68 & 17,61 & 17,89 & 8,11 & 17,75 & 17,85 & 18,05 & 17,72 & 17,83 & 17,64 & 17,77 & 17,49 \\
\hline $\mathrm{Cr} 2 \mathrm{O} 3$ & 0 & 0 & 0 & 0 & 0 & 0 & 0 & 0 & 0 & 0 & 0 & 0 & 0 & 0 & 0 & 0 & 0 & 0 & 0 & 0 & 0 & 0 \\
\hline $\mathrm{Fe} 2 \mathrm{O} 3$ & 0 & 0 & 0 & 0 & 0 & 0 & 0 & 0 & 0 & 0 & 0 & 0 & 0 & 0 & 0 & 0 & 0 & 0 & 0 & 0 & 0 & 0 \\
\hline $\mathrm{FeO}$ & 0 & 0 & 0 & 0 & 0 & 0 & 0 & 0 & 0 & 0 & 0 & 0 & 0 & 0 & 0 & 0 & 0 & 0 & 0 & 0 & 0 & 0 \\
\hline $\mathrm{MnO}$ & 0 & 0 & 0 & 0 & 0 & 0 & 0 & 0 & 0 & 0 & 0 & 0 & 0 & 0 & 0 & 0 & 0 & 0 & 0 & 0 & 0 & 0 \\
\hline $\mathrm{MgO}$ & 0 & 0 & 0 & 0 & 0 & 0 & 0 & 0 & 0 & 0 & 0 & 0 & 0 & 0 & 0 & 0 & 0 & 0 & 0 & 0 & 0 & 0 \\
\hline $\mathrm{CaO}$ & 2,22 & 2,24 & 2,21 & 2,19 & 2,26 & 2,28 & 2,26 & 2,24 & 2,21 & 2,25 & 2,29 & 2,32 & 2,29 & 0,99 & 2,27 & 2,31 & 2,29 & 2,24 & 2,26 & 2,27 & 2,25 & 2,31 \\
\hline $\mathrm{Na} 2 \mathrm{O}$ & 0,51 & 0,62 & 0,63 & 0,65 & 0,69 & 0,53 & 0,67 & 0,71 & 0,67 & 0,59 & 0,62 & 0,6 & 0,55 & 0,11 & 0,67 & 0,51 & 0,57 & 0,59 & 0,7 & 0,65 & 0,63 & 0,25 \\
\hline $\mathrm{K} 2 \mathrm{O}$ & 15,86 & 15,48 & 15,43 & 15,63 & 15,36 & 15,56 & 15,53 & 15,55 & 15,52 & 15,9 & 15,72 & 15,69 & 15,99 & 7,3 & 15,68 & 15,94 & 16,05 & 15,91 & 15,72 & 15,46 & 15,74 & 15,73 \\
\hline Totals & 99,76 & 99,79 & 99,2 & 99,7 & 100,16 & 99,69 & 100,31 & 100,05 & 99,85 & 100,07 & 100,44 & 100,47 & 101,04 & 101,91 & 100,72 & 100,72 & 101,47 & 100,64 & 100,69 & 99,97 & 100,04 & 98,23 \\
\hline Oxygens & 8 & 8 & 8 & 8 & 8 & 8 & 8 & 8 & 8 & 8 & 8 & 8 & 8 & 8 & 8 & 8 & 8 & 8 & 8 & 8 & 8 & 8 \\
\hline $\mathrm{Si}$ & 2,968 & 2,972 & 2,966 & 2,964 & 2,981 & 2,965 & 2,974 & 2,968 & 2,974 & 2,965 & 2,972 & 2,975 & 2,965 & 3,577 & 2,973 & 2,965 & 2,963 & 2,97 & 2,967 & 2,974 & 2,964 & 2,964 \\
\hline $\mathrm{Ti}$ & 0 & 0 & 0 & 0 & 0 & 0 & 0 & 0 & 0 & 0 & 0 & 0 & 0 & 0 & 0 & 0 & 0 & 0 & 0 & 0 & 0 & 0 \\
\hline $\mathrm{Al}$ & 0,971 & 0,971 & 0,975 & 0,979 & 0,96 & 0,979 & 0,967 & 0,972 & 0,967 & 0,967 & 0,966 & 0,961 & 0,973 & 0,401 & 0,967 & 0,974 & 0,977 & 0,967 & 0,972 & 0,967 & 0,975 & 0,979 \\
\hline $\mathrm{Cr}$ & 0 & 0 & 0 & 0 & 0 & 0 & 0 & 0 & 0 & 0 & 0 & 0 & 0 & 0 & 0 & 0 & 0 & 0 & 0 & 0 & 0 & 0 \\
\hline $\mathrm{Fe} 3$ & 0 & 0 & 0,004 & 0 & 0 & 0 & 0 & 0 & 0 & 0,005 & 0,001 & 0,001 & 0,001 & 0 & 0 & 0,001 & 0 & 0,001 & 0,001 & 0 & 0 & 0 \\
\hline $\mathrm{Fe} 2$ & 0 & 0 & 0 & 0 & 0 & 0 & 0 & 0 & 0 & 0 & 0 & 0 & 0 & 0 & 0 & 0 & 0 & 0 & 0 & 0 & 0 & 0 \\
\hline $\mathrm{Mn}$ & 0 & 0 & 0 & 0 & 0 & 0 & 0 & 0 & 0 & 0 & 0 & 0 & 0 & 0 & 0 & 0 & 0 & 0 & 0 & 0 & 0 & 0 \\
\hline $\mathrm{Mg}$ & 0 & 0 & 0 & 0 & 0 & 0 & 0 & 0 & 0 & 0 & 0 & 0 & 0 & 0 & 0 & 0 & 0 & 0 & 0 & 0 & 0 & 0 \\
\hline $\mathrm{Ca}$ & 0,111 & 0,112 & 0,111 & 0,109 & 0,112 & 0,114 & 0,112 & 0,112 & 0,11 & 0,112 & 0,113 & 0,115 & 0,113 & 0,044 & 0,112 & 0,115 & 0,113 & 0,111 & 0,112 & 0,113 & 0,112 & 0,118 \\
\hline $\mathrm{Na}$ & 0,046 & 0,056 & 0,057 & 0,059 & 0,062 & 0,048 & 0,061 & 0,064 & 0,061 & 0,053 & 0,056 & 0,054 & 0,049 & 0,009 & 0,06 & 0,046 & 0,051 & 0,053 & 0,063 & 0,059 & 0,056 & 0,023 \\
\hline $\mathrm{K}$ & 0,945 & 0,92 & 0,923 & 0,931 & 0,908 & 0,927 & 0,919 & 0,923 & 0,922 & 0,944 & 0,929 & 0,927 & 0,941 & 0,39 & 0,924 & 0,941 & 0,941 & 0,94 & 0,928 & 0,917 & 0,935 & 0,952 \\
\hline Sum & 5,043 & 5,031 & 5,035 & 5,043 & 5,025 & 5,033 & 5,033 & 5,04 & 5,035 & 5,048 & 5,038 & 5,034 & 5,043 & 4,422 & 5,036 & 5,041 & 5,045 & 5,043 & 5,042 & 5,031 & 5,044 & 5,035 \\
\hline
\end{tabular}




\section{Amostra ALFE24b - Granada}

\begin{tabular}{|c|c|c|c|c|c|c|c|c|c|c|c|c|c|c|c|c|c|c|c|c|c|c|}
\hline Sample & 101 & 102 & 103 & 104 & 105 & 106 & 201 & 202 & 203 & 204 & 205 & 206 & 207 & 208 & 209 & 301 & 302 & 303 & 304 & 305 & 306 & 307 \\
\hline Min & $\mathrm{g}$ & $\mathrm{g}$ & $\mathrm{g}$ & g & $\mathrm{g}$ & $\mathrm{g}$ & $\mathrm{g}$ & $\mathrm{g}$ & $\mathrm{g}$ & $\mathrm{g}$ & $\mathrm{g}$ & $\mathrm{g}$ & $\mathrm{g}$ & $\mathrm{g}$ & $\mathrm{g}$ & $\mathrm{g}$ & $\mathrm{g}$ & $\mathrm{g}$ & $\mathrm{g}$ & $\mathrm{g}$ & g & $\mathrm{g}$ \\
\hline $\mathrm{SiO} 2$ & 39,51 & 39,28 & 39,06 &, 34 & 39,34 & 39,25 & 39,28 & 38,96 & 38,72 & 38,38 & 65,73 & 38,63 & 39,08 & 39,23 & 39,17 & 39,03 & 38,94 & 39,2 & 38,95 & 38,77 & 38,79 & 39,18 \\
\hline $\mathrm{TiO} 2$ & 0,02 & 0 & 0,02 & 0 & 0,02 & 0,01 & 0,03 & 0,03 & 0,02 & 0,04 & 0 & 0,02 & 0,02 & 0,03 & 0,02 & 0,03 & 0,03 & 0,01 & 0,02 & 0,04 & 0,04 & 0,03 \\
\hline $\mathrm{A} 12 \mathrm{O} 3$ & 20,29 & 20,35 & 20,5 & 20,45 & 20,25 & 20,36 & 19,66 & 20,02 & 19,78 & 19,78 & 19,51 & 20,02 & 19,79 & 19,97 & 20,26 & 20,05 & 20,13 & 20,45 & 20,22 & 19,98 & 20,28 & 19,89 \\
\hline $\mathrm{Cr} 2 \mathrm{O} 3$ & 0 & 0 & 0 & 0 & 0 & 0 & 0 & 0 & 0 & 0 & 0 & 0 & 0 & 0 & 0 & 0 & 0 & 0 & 0 & 0 & 0 & 0 \\
\hline $\mathrm{Fe} 2 \mathrm{O} 3$ & 0 & 0 & 0 & 0 & 0 & 0 & 0 & 0 & 0 & 0 & 0 & 0 & 0 & 0 & 0 & 0 & 0 & 0 & 0 & 0 & 0 & 0 \\
\hline $\mathrm{FeO}$ & 28,47 & 28,5 & 29,32 & 29,73 & 29,18 & 29,89 & 29,15 & 28,31 & 27,7 & 27,38 & 0,29 & 29,47 & 28,24 & 29,32 & 29,02 & 29,14 & 28,66 & 28,08 & 27,67 & 28,3 & 28,89 & 29,33 \\
\hline $\mathrm{MnO}$ & 0,37 & 0,35 & 0,41 & 0,39 & 0,39 & 038 & 0,42 & 0,35 & 0,29 & 0,34 & 0,01 & 0,34 & 0,36 & 0,36 & 0,37 & 0,37 & 0,34 & 0,36 & 0,33 & 0,33 & 0,37 & 0,38 \\
\hline $\mathrm{MgO}$ & 0,05 & 0 & 0 & 0 & 0 & 0 & 0,02 & 0 & 0 & 0,01 & 0 & 0,06 & 0,01 & 0 & 0 & 0,03 & 0,01 & 0,01 & 0 & 0,01 & 0,03 & 0,01 \\
\hline $\mathrm{CaO}$ & 12,78 & 12,6 & 12,18 & 12,23 & 12,15 & 11,92 & 11,47 & 12,46 & 12,85 & 12,57 & 2,52 & 11,56 & 12,07 & 11,37 & 11,45 & 11,75 & 12,54 & 12,69 & 13,21 & 12,39 & 11,89 & 11,52 \\
\hline $\mathrm{Na} 2 \mathrm{O}$ & 0 & 0 & 0 & 0 & 0 & 0 & 0 & 0 & 0 & 0 & 0 & 0 & 0 & م & 0 & 0 & 0 & 0 & 0 & 0 & 0 & 0 \\
\hline $\mathrm{K} 2 \mathrm{O}$ & 0 & 0 & 0 & 0 & 0 & 0 & 0 & 0 & 0 & 0 & 0 & 0 & 0 & 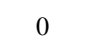 & 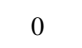 & 0 & 0 & 0 & 0 & 0 & 0 & 0 \\
\hline Totals & 101,48 & 101,09 & 101,5 & 102,14 & 101,32 & 101,82 & 100,04 & 100,13 & 99,36 & 98,48 & 88,06 & 100,1 & 99,56 & 100,28 & 100,28 & 100,39 & 100,66 & 100,8 & 100,4 & 99,82 & 100,29 & 100,3 \\
\hline Oxyger & 12 & 12 & 12 & 12 & 12 & 1 & 1 & 12 & 12 & 12 & 12 & 12 & 12 & 12 & 12 & 12 & 12 & 12 & 12 & 12 & 12 & 12 \\
\hline $\mathrm{Si}$ & 3,103 & 3,097 & 3,077 & 3,083 & 3,1 & 3,086 & 3,133 & 3,103 & 3,105 & 3,102 & 4,669 & 3,088 & 3,125 & 3,121 & 3,112 & 3,105 & 3,09 & 3,095 & 3,09 & 3,098 & 3,087 & 3,118 \\
\hline $\mathrm{Ti}$ & 0,001 & 0 & 0,001 & 0 & 0,001 & 0,001 & 0,002 & 0,002 & 0,001 & 0,002 & 0 & 0,001 & 0,001 & 0,002 & 0,001 & 0,002 & 0,002 & 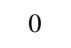 & 0,001 & 0,003 & 0,002 & 0,002 \\
\hline $\mathrm{Al}$ & 1,878 & 1,892 & 1,904 & 1,889 & 1,881 & 1,887 & 1,849 & 1,879 & 1,87 & 1,885 & 1,634 & 1,887 & 1,866 & 1,873 & 1,898 & 1,88 & 1,883 & 1,904 & 1,891 & 1,882 & 1,903 & 1,866 \\
\hline $\mathrm{Cr}$ & 0 & 0 & 0 & 0 & . & 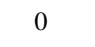 & 0 & 0 & 0 & 0 & 0 & 0 & 0 & 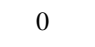 & 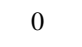 & 0 & 0 & 0 & 0 & 0 & 0 & 0 \\
\hline $\mathrm{Fe} 3$ & 0 & 0 & 0 & 0 & 0 & 0 & 0 & 0 & 0 & 0 & 0 & م & - & 0 & 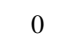 & 0 & 0 & 0 & 0 & 0 & 0 & 0 \\
\hline $\mathrm{Fe} 2$ & 1,87 & 1,879 & 1,932 & 1,948 & 1,923 & 1,966 & 1,944 & 1,885 & 1,858 & 1,851 & 0,017 & 1,971 & 1,889 & 1,951 & 1,928 & 1,938 & 1,902 & 1,854 & 1,836 & 1,891 & 1,924 & 1,952 \\
\hline $\mathrm{Mn}$ & 0,025 & 0,024 & 0,027 & 0,026 & 0,026 & 0,025 & 0,028 & 0,024 & 0,02 & 0,023 & 0,001 & 0,023 & 0,025 & 0,024 & 0,025 & 0,025 & 0,023 & 0,024 & 0,022 & 0,022 & 0,025 & 0,026 \\
\hline $\mathrm{Mg}$ & 0,006 & 0 & 0 & 0 & 0 & 0 & 0,003 & 0 & 0 & 0,001 & 0 & 0,007 & 0,001 & . & 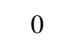 & 0,003 & 0,002 & 0,001 & 0 & 0,001 & 0,003 & 0,001 \\
\hline $\mathrm{Ca}$ & 1,075 & 1,065 & 1,028 & 1,027 & 1,026 & 1,005 & 0,981 & 1,063 & 1,104 & 1,089 & 0,192 & 0,991 & 1,034 & 0,969 & 0,975 & 1,002 & 1,066 & 1,074 & 1,123 & 1,061 & 1,015 & 0,982 \\
\hline $\mathrm{Na}$ & 0 & 0 & 0 & 0 & 0 & 0 & 0 & 0 & 0 & 0 & 0 & 0 & 0 & م & 0 & 0 & 0 & 0 & 0 & 0 & 0 & 0 \\
\hline K & 0 & 0 & 0 & 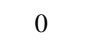 & 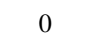 & 0 & 0 & 0 & 0 & 0 & 0 & 0 & 0 & 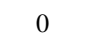 & 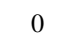 & 0 & 0 & 0 & 0 & 0 & 0 & 0 \\
\hline Sum & 7,957 & 7,957 & 7,97 & 7,973 & 7,958 & 7,97 & 7,941 & 7,956 & 7,959 & 7,953 & 6,513 & 7,967 & 7,941 & 7,941 & 7,939 & 7,954 & 7,967 & 7,953 & 7,964 & 7,959 & 7,959 & 7,947 \\
\hline
\end{tabular}


Amostra ALFE24b - Anfibólio

\begin{tabular}{|c|c|c|c|c|c|c|c|c|c|c|c|c|c|c|}
\hline Sample & 101 & 102 & 103 & 201 & 202 & 203 & 204 & 301 & 302 & 303 & 304 & 305 & 306 & 307 \\
\hline Min & amph & amph & amph & amph & amph & amph & amph & amph & amph & amph & amph & amph & amph & amph \\
\hline $\mathrm{SiO} 2$ & 40,58 & 38,53 & 38,78 & 38,14 & 39,01 & 38,75 & 38,25 & 38,08 & 38,34 & 38,62 & 38,58 & 38,34 & 38,6 & 38,64 \\
\hline $\mathrm{TiO} 2$ & 0,66 & 1 & 1,01 & 1,28 & 1,35 & 1,24 & 1,39 & 1,16 & 1,46 & 1,42 & 1,19 & 1,23 & 1,17 & 1,04 \\
\hline $\mathrm{A} 12 \mathrm{O} 3$ & 12,77 & 12,35 & 12,35 & 12,03 & 11,78 & 11,85 & 12,76 & 11,89 & 11,73 & 11,81 & 12,06 & 11,86 & 11,84 & 12,18 \\
\hline $\mathrm{Cr} 2 \mathrm{O} 3$ & 0 & 0 & 0 & 0 & 0 & 0 & 0 & 0 & 0 & 0 & 0 & 0 & 0 & 0 \\
\hline $\mathrm{Fe} 2 \mathrm{O} 3$ & 2,28 & 3,39 & 3,33 & 3,36 & 2,78 & 2,85 & 2,74 & 5,88 & 2,73 & 3,31 & 2,97 & 2,81 & 2,17 & 1,02 \\
\hline $\mathrm{FeO}$ & 29,52 & 29,24 & 29,47 & 29,57 & 30,16 & 30,01 & 29,42 & 28,68 & 30,27 & 30,25 & 29,84 & 29,98 & 30 & 29,86 \\
\hline $\mathrm{MnO}$ & 0,12 & 0,08 & 0,08 & 0,06 & 0,07 & 0,06 & 0,07 & 0,09 & 0,01 & 0,04 & 0,07 & 0,03 & 0,06 & 0,06 \\
\hline $\mathrm{MgO}$ & 0,51 & 0,61 & 0,61 & 0,65 & 0,71 & 0,66 & 0,64 & 0,58 & 0,66 & 0,61 & 0,61 & 0,64 & 0,7 & 0,65 \\
\hline $\mathrm{CaO}$ & 10,37 & 10,61 & 10,82 & 10,54 & 10,4 & 10,55 & 10,63 & 11,02 & 10,77 & 10,61 & 10,82 & 10,55 & 10,5 & 10,61 \\
\hline $\mathrm{Na} 2 \mathrm{O}$ & 1,18 & 1,21 & 1,22 & 1,74 & 1,86 & 1,89 & 1,27 & 1,22 & 1,55 & 1,54 & 1,34 & 1,64 & 1,73 & 1,63 \\
\hline $\mathrm{K} 2 \mathrm{O}$ & 2,45 & 2,54 & 2,48 & 2,46 & 2,46 & 2,46 & 2,63 & 2,35 & 2,47 & 2,47 & 2,5 & 2,41 & 2,44 & 2,56 \\
\hline Totals & 100,44 & 99,56 & 100,14 & 99,83 & 100,56 & 100,32 & 99,79 & 100,95 & 99,99 & 100,66 & 99,99 & 99,5 & 99,22 & 98,25 \\
\hline Oxygens & 23 & 23 & 23 & 23 & 23 & 23 & 23 & 23 & 23 & 23 & 23 & 23 & 23 & 23 \\
\hline $\mathrm{Si}$ & 6,364 & 6,162 & 6,166 & 6,11 & 6,194 & 6,173 & 6,102 & 6,041 & 6,14 & 6,141 & 6,16 & 6,16 & 6,207 & 6,253 \\
\hline $\mathrm{Ti}$ & 0,077 & 0,121 & 0,121 & 0,155 & 0,161 & 0,148 & 0,167 & 0,138 & 0,176 & 0,169 & 0,143 & 0,148 & 0,142 & 0,127 \\
\hline $\mathrm{Al}$ & 2,361 & 2,328 & 2,314 & 2,272 & 2,205 & 2,226 & 2,401 & 2,225 & 2,215 & 2,214 & 2,27 & 2,246 & 2,244 & 2,325 \\
\hline $\mathrm{Cr}$ & 0 & 0 & 0 & 0 & 0 & 0 & 0 & 0 & 0 & 0 & 0 & 0 & 0 & 0 \\
\hline $\mathrm{Fe} 3$ & 0,269 & 0,408 & 0,399 & 0,404 & 0,332 & 0,341 & 0,33 & 0,703 & 0,329 & 0,397 & 0,357 & 0,34 & 0,263 & 0,125 \\
\hline $\mathrm{Fe} 2$ & 3,871 & 3,911 & 3,918 & 3,962 & 4,005 & 3,999 & 3,925 & 3,805 & 4,054 & 4,021 & 3,984 & 4,029 & 4,036 & 4,041 \\
\hline $\mathrm{Mn}$ & 0,016 & 0,01 & 0,011 & 0,008 & 0,009 & 0,008 & 0,009 & 0,012 & 0,001 & 0,005 & 0,009 & 0,004 & 0,008 & 0,008 \\
\hline $\mathrm{Mg}$ & 0,119 & 0,146 & 0,145 & 0,155 & 0,168 & 0,156 & 0,153 & 0,137 & 0,157 & 0,144 & 0,145 & 0,154 & 0,168 & 0,156 \\
\hline $\mathrm{Ca}$ & 1,742 & 1,817 & 1,843 & 1,809 & 1,77 & 1,802 & 1,816 & 1,874 & 1,847 & 1,807 & 1,851 & 1,816 & 1,81 & 1,84 \\
\hline $\mathrm{Na}$ & 0,36 & 0,374 & 0,377 & 0,542 & 0,572 & 0,583 & 0,392 & 0,376 & 0,482 & 0,475 & 0,415 & 0,511 & 0,541 & 0,51 \\
\hline $\mathrm{K}$ & 0,49 & 0,519 & 0,502 & 0,504 & 0,497 & 0,501 & 0,535 & 0,475 & 0,505 & 0,5 & 0,51 & 0,494 & 0,5 & 0,528 \\
\hline Sum & 15,762 & 15,938 & 15,935 & 16,062 & 16,028 & 16,056 & 15,944 & 16,029 & 16,021 & 16,011 & 15,969 & 16,02 & 16,01 & 15,957 \\
\hline
\end{tabular}


Amostra ALFE24b - Plagioclásio

\begin{tabular}{|c|c|c|c|c|c|c|c|c|c|c|c|c|c|c|c|c|c|c|c|c|c|c|}
\hline Sample & 101 & 102 & 103 & 104 & 201 & 202 & 203 & 301 & 302 & 303 & 401 & 402 & 403 & 404 & 501 & 502 & 503 & 601 & 602 & 603 & 604 & 605 \\
\hline Min & fsp & fsp & fsp & fsp & fsp & fsp & fsp & fsp & fsp & fsp & fsp & fsp & fsp & fsp & fsp & fsp & fsp & fsp & fsp & fsp & fsp & fsp \\
\hline $\mathrm{SiO} 2$ & 67,1 & 66,63 & 65,47 & 68,11 & 65,77 & 66,55 & 68,1 & 66,85 & 65,56 & 65,62 & 65,73 & 66,3 & 66,73 & 65,98 & 66,8 & 66,12 & 67,74 & 67,53 & 66,4 & 67,33 & 67,15 & 67,74 \\
\hline $\mathrm{TiO} 2$ & 0 & 0 & 0 & 0 & 0 & 0 & 0 & 0 & 0 & 0 & 0 & 0 & 0 & 0 & 0 & 0 & 0 & 0 & 0 & 0 & 0 & 0 \\
\hline $\mathrm{A} 12 \mathrm{O} 3$ & 19,85 & 20,67 & 20,43 & 19,63 & 21,09 & 20,98 & 19,62 & 20,07 & 20,8 & 20,87 & 21,02 & 20,73 & 20,68 & 20,88 & 20,92 & 20,99 & 20,45 & 20,84 & 20,33 & 20,57 & 20,73 & 20,77 \\
\hline $\mathrm{Cr} 2 \mathrm{O} 3$ & 0 & 0 & 0 & 0 & 0 & 0 & 0 & 0 & 0 & 0 & 0 & 0 & 0 & 0 & 0 & 0 & 0 & 0 & 0 & 0 & 0 & 0 \\
\hline $\mathrm{Fe} 2 \mathrm{O} 3$ & 0 & 0 & 0 & 0 & 0 & 0 & 0 & 0 & 0 & 0 & 0 & 0 & 0 & 0 & 0 & 0 & 0 & 0 & 0 & 0 & 0 & 0 \\
\hline $\mathrm{FeO}$ & 0 & 0 & 0 & 0 & 0 & 0 & 0 & 0 & 0 & 0 & 0 & 0 & 0 & 0 & 0 & 0 & 0 & 0 & 0 & 0 & 0 & 0 \\
\hline $\mathrm{MnO}$ & 0 & 0 & 0 & 0 & 0 & 0 & 0 & 0 & 0 & 0 & 0 & 0 & 0 & 0 & 0 & 0 & 0 & 0 & 0 & 0 & 0 & 0 \\
\hline $\mathrm{MgO}$ & 0 & 0 & 0 & 0 & 0 & 0 & 0 & 0 & 0 & 0 & 0 & 0 & 0 & 0 & 0 & 0 & 0 & 0 & 0 & 0 & 0 & 0 \\
\hline $\mathrm{CaO}$ & 1,46 & 2,24 & 2,12 & 0,99 & 2,53 & 2,47 & 1,08 & 1,46 & 2,26 & 2,44 & 2,5 & 2,08 & 2,1 & 2,18 & 2,29 & 2,31 & 1,69 & 1,86 & 1,52 & 2,02 & 2,2 & 2,18 \\
\hline $\mathrm{Na} 2 \mathrm{O}$ & 11,09 & 10,07 & 10,24 & 11,07 & 10,24 & 10,38 & 11,27 & 10,94 & 10,52 & 10,41 & 10,32 & 10,1 & 10,61 & 10,55 & 10,56 & 10,49 & 10,81 & 10,59 & 10,25 & 10,62 & 10,52 & 10,63 \\
\hline $\mathrm{K} 2 \mathrm{O}$ & 0,07 & 0,08 & 0,12 & 0,03 & 0,09 & 0,07 & 0,06 & 0,07 & 0,09 & 0,14 & 0,1 & 0,28 & 0,06 & 0,08 & 0,05 & 0,03 & 0,05 & 0,09 & 0,65 & 0,09 & 0,12 & 0,13 \\
\hline Totals & 99,56 & 99,68 & 98,38 & 99,83 & 99,73 & 100,44 & 100,13 & 99,38 & 99,23 & 99,48 & 99,68 & 99,48 & 100,17 & 99,67 & 100,62 & 99,94 & 100,74 & 100,91 & 99,16 & 100,63 & 100,72 & 101,46 \\
\hline Oxygens & 8 & 8 & 8 & 8 & 8 & 8 & 8 & 8 & 8 & 8 & 8 & 8 & 8 & 8 & 8 & 8 & 8 & 8 & 8 & 8 & 8 & 8 \\
\hline $\mathrm{Si}$ & 2,955 & 2,927 & 2,92 & 2,981 & 2,898 & 2,91 & 2,977 & 2,948 & 2,904 & 2,901 & 2,898 & 2,923 & 2,924 & 2,908 & 2,915 & 2,906 & 2,945 & 2,932 & 2,939 & 2,934 & 2,926 & 2,93 \\
\hline $\mathrm{Ti}$ & 0 & 0 & 0 & 0 & 0 & 0 & 0 & 0 & 0 & 0 & 0 & 0 & 0 & 0 & 0 & 0 & 0 & 0 & 0 & 0 & 0 & 0 \\
\hline $\mathrm{Al}$ & 1,03 & 1,07 & 1,074 & 1,013 & 1,096 & 1,081 & 1,011 & 1,043 & 1,086 & 1,088 & 1,093 & 1,077 & 1,068 & 1,085 & 1,076 & 1,088 & 1,048 & 1,067 & 1,06 & 1,057 & 1,065 & 1,059 \\
\hline $\mathrm{Cr}$ & 0 & 0 & 0 & 0 & 0 & 0 & 0 & 0 & 0 & 0 & 0 & 0 & 0 & 0 & 0 & 0 & 0 & 0 & 0 & 0 & 0 & 0 \\
\hline $\mathrm{Fe} 3$ & 0,001 & 0,002 & 0 & 0 & 0 & 0 & 0 & 0,001 & 0,001 & 0 & 0,002 & 0,001 & 0 & 0 & 0 & 0 & 0,001 & 0 & 0,001 & 0 & 0,001 & 0 \\
\hline $\mathrm{Fe} 2$ & 0 & 0 & 0 & 0 & 0 & 0 & 0 & 0 & 0 & 0 & 0 & 0 & 0 & 0 & 0 & 0 & 0 & 0 & 0 & 0 & 0 & 0 \\
\hline $\mathrm{Mn}$ & 0 & 0 & 0 & 0 & 0 & 0 & 0 & 0 & 0 & 0 & 0 & 0 & 0 & 0 & 0 & 0 & 0 & 0 & 0 & 0 & 0 & 0 \\
\hline $\mathrm{Mg}$ & 0 & 0 & 0 & 0 & 0 & 0 & 0 & 0 & 0 & 0 & 0 & 0 & 0 & 0 & 0 & 0 & 0 & 0 & 0 & 0 & 0 & 0 \\
\hline $\mathrm{Ca}$ & 0,069 & 0,105 & 0,101 & 0,046 & 0,12 & 0,116 & 0,051 & 0,069 & 0,107 & 0,115 & 0,118 & 0,098 & 0,098 & 0,103 & 0,107 & 0,109 & 0,079 & 0,087 & 0,072 & 0,094 & 0,103 & 0,101 \\
\hline $\mathrm{Na}$ & 0,946 & 0,858 & 0,886 & 0,939 & 0,875 & 0,88 & 0,955 & 0,935 & 0,904 & 0,892 & 0,883 & 0,864 & 0,901 & 0,902 & 0,893 & 0,894 & 0,911 & 0,891 & 0,88 & 0,897 & 0,889 & 0,892 \\
\hline $\mathrm{K}$ & 0,004 & 0,004 & 0,007 & 0,002 & 0,005 & 0,004 & 0,003 & 0,004 & 0,005 & 0,008 & 0,006 & 0,015 & 0,003 & 0,005 & 0,003 & 0,001 & 0,003 & 0,005 & 0,037 & 0,005 & 0,006 & 0,007 \\
\hline Sum & 5,005 & 4,967 & 4,989 & 4,983 & 4,994 & 4,991 & 4,997 & 5 & 5,007 & 5,005 & 4,999 & 4,978 & 4,994 & 5,003 & 4,995 & 4,998 & 4,987 & 4,982 & 4,989 & 4,988 & 4,989 & 4,99 \\
\hline
\end{tabular}


ALFE45i - Granada

\begin{tabular}{cccccccccccc} 
Sample & 101 & 102 & 103 & 104 & 105 & 106 & 201 & 202 & 203 & 204 & 205 \\
\hline $\mathrm{Min}$ & $\mathrm{g}$ & $\mathrm{g}$ & $\mathrm{g}$ & $\mathrm{g}$ & $\mathrm{g}$ & $\mathrm{g}$ & $\mathrm{g}$ & $\mathrm{g}$ & $\mathrm{g}$ & $\mathrm{g}$ & $\mathrm{g}$ \\
$\mathrm{SiO} 2$ & 39,01 & 38,87 & 38,55 & 38,93 & 38,88 & 38,53 & 38,77 & 38,73 & 38,61 & 38,95 & 38,23 \\
$\mathrm{TiO} 2$ & 0,01 & 0,09 & 0,06 & 0,07 & 0,06 & 0,06 & 0,04 & 0,07 & 0,01 & 0,05 & 0,01 \\
$\mathrm{~A} 2 \mathrm{O} 3$ & 22,01 & 21,78 & 21,7 & 21,79 & 22 & 22,01 & 21,82 & 22,09 & 21,74 & 22,08 & 21,51 \\
$\mathrm{Cr} 2 \mathrm{O} 3$ & 0 & 0 & 0 & 0 & 0 & 0 & 0 & 0 & 0 & 0 & 0 \\
$\mathrm{Fe} 2 \mathrm{O} 3$ & 0 & 0 & 0 & 0 & 0 & 0 & 0 & 0 & 0 & 0,05 & 0,11 \\
$\mathrm{FeO}$ & 24,92 & 24,48 & 24,06 & 25 & 24,99 & 25,33 & 25,32 & 24,87 & 24,82 & 25,71 & 25,97 \\
$\mathrm{MnO}$ & 4,43 & 4,58 & 4,49 & 4,5 & 4,5 & 4,43 & 4,46 & 4,6 & 4,41 & 4,35 & 4,28 \\
$\mathrm{MgO}$ & 5,2 & 5,31 & 5,19 & 5,37 & 5,29 & 5,07 & 5,16 & 5,4 & 5,26 & 4,9 & 4,49 \\
$\mathrm{CaO}$ & 5,5 & 5,34 & 5,46 & 5,48 & 5,37 & 5,54 & 5,59 & 5,35 & 5,54 & 6,05 & 5,79 \\
$\mathrm{Na} 2 \mathrm{O}$ & 0 & 0 & 0 & 0 & 0 & 0 & 0 & 0 & 0 & 0 & 0 \\
$\mathrm{~K} 2 \mathrm{O}$ & 0 & 0 & 0 & 0 & 0 & 0 & 0 & 0 & 0 & 0 & 0
\end{tabular}

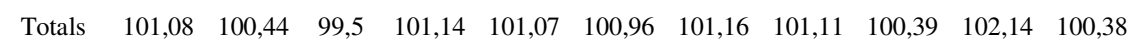

$\begin{array}{cccccccccccc}\text { Oxygens } & 12 & 12 & 12 & 12 & 12 & 12 & 12 & 12 & 12 & 12 & 12 \\ \mathrm{Si} & 3,016 & 3,022 & 3,022 & 3,012 & 3,009 & 2,993 & 3,005 & 2,997 & 3,01 & 2,995 & 3,001 \\ \mathrm{Ti} & 0,001 & 0,005 & 0,003 & 0,004 & 0,003 & 0,004 & 0,002 & 0,004 & 0 & 0,003 & 0,001 \\ \mathrm{Al} & 2,006 & 1,996 & 2,006 & 1,988 & 2,007 & 2,015 & 1,994 & 2,015 & 1,998 & 2,002 & 1,99 \\ \mathrm{Cr} & 0 & 0 & 0 & 0 & 0 & 0 & 0 & 0 & 0 & 0 & 0 \\ \mathrm{Fe} 3 & 0 & 0 & 0 & 0 & 0 & 0 & 0 & 0 & 0 & 0,002 & 0,006 \\ \mathrm{Fe} 2 & 1,611 & 1,591 & 1,578 & 1,618 & 1,617 & 1,645 & 1,642 & 1,61 & 1,618 & 1,654 & 1,705 \\ \mathrm{Mn} & 0,29 & 0,302 & 0,298 & 0,295 & 0,295 & 0,291 & 0,293 & 0,301 & 0,291 & 0,283 & 0,284 \\ \mathrm{Mg} & 0,599 & 0,615 & 0,606 & 0,62 & 0,609 & 0,586 & 0,596 & 0,622 & 0,611 & 0,562 & 0,525 \\ \mathrm{Ca} & 0,455 & 0,444 & 0,459 & 0,454 & 0,445 & 0,461 & 0,465 & 0,444 & 0,463 & 0,499 & 0,487 \\ \mathrm{Na} & 0 & 0 & 0 & 0 & 0 & 0 & 0 & 0 & 0 & 0 & 0 \\ \mathrm{~K} & 0 & 0 & 0 & 0 & 0 & 0 & 0 & 0 & 0 & 0 & 0 \\ \mathrm{Sum} & 7,98 & 7,975 & 7,972 & 7,99 & 7,985 & 7,996 & 7,996 & 7,992 & 7,991 & 8 & 8\end{array}$


ALFE45i - Granada

\begin{tabular}{|c|c|c|c|c|c|c|c|c|c|c|c|c|c|c|c|}
\hline Sample & 401 & 402 & 403 & 404 & 405 & 406 & 407 & 408 & 409 & 410 & 411 & 412 & 413 & 414 & 415 \\
\hline Min & $\mathrm{g}$ & $\mathrm{g}$ & $\mathrm{g}$ & $\mathrm{g}$ & $\mathrm{g}$ & $\mathrm{g}$ & $\mathrm{g}$ & $\mathrm{g}$ & $\mathrm{g}$ & $\mathrm{g}$ & $\mathrm{g}$ & $\mathrm{g}$ & $\mathrm{g}$ & $\mathrm{g}$ & $\mathrm{g}$ \\
\hline $\mathrm{SiO} 2$ & 38,76 & 38,92 & 38,58 & 38,77 & 38,65 & 38,78 & 38,76 & 38,6 & 38,52 & 38,7 & 38,5 & 38,84 & 38,62 & 38,87 & 37,5 \\
\hline $\mathrm{TiO} 2$ & 0,07 & 0,06 & 0,05 & 0,08 & 0,03 & 0,01 & 0,08 & 0,11 & 0,1 & 0,08 & 0,04 & 0,07 & 0,08 & 0 & 0,05 \\
\hline $\mathrm{Al} 2 \mathrm{O} 3$ & 21,77 & 21,98 & 22,27 & 22,09 & 21,92 & 22,09 & 21,82 & 21,81 & 22,08 & 21,73 & 21,48 & 21,92 & 21,67 & 22,21 & 20,9 \\
\hline $\mathrm{Cr} 2 \mathrm{O} 3$ & 0 & 0 & 0 & 0 & 0 & 0 & 0 & 0 & 0 & 0 & 0 & 0 & 0 & 0 & 0 \\
\hline $\mathrm{Fe} 2 \mathrm{O} 3$ & 0 & 0 & 1,01 & 0 & 0,22 & 0,13 & 0 & 0,62 & 0 & 0 & 0,01 & 0 & 0 & 0,1 & 1,57 \\
\hline $\mathrm{FeO}$ & 25,71 & 25,2 & 24,61 & 24,46 & 24,76 & 24,59 & 25,09 & 24,83 & 25,32 & 26,55 & 26,28 & 24,84 & 25,02 & 25,94 & 25,58 \\
\hline $\mathrm{MnO}$ & 4,25 & 4,42 & 4,32 & 4,4 & 4,32 & 4,31 & 4,36 & 4,47 & 4,39 & 4,38 & 4,41 & 4,4 & 4,4 & 4,34 & 4,41 \\
\hline $\mathrm{MgO}$ & 4,99 & 5,44 & 5,76 & 5,63 & 5,68 & 5,84 & 5,54 & 5,58 & 5,22 & 4,59 & 4,74 & 5,19 & 5,37 & 5,13 & 4,54 \\
\hline $\mathrm{CaO}$ & 5,66 & 5,39 & 5,4 & 5,46 & 5,45 & 5,47 & 5,39 & 5,43 & 5,35 & 5,27 & 5,37 & 5,53 & 5,48 & 5,46 & 5,26 \\
\hline $\mathrm{Na} 2 \mathrm{O}$ & 0 & 0 & 0 & 0 & 0 & 0 & 0 & 0 & 0 & 0 & 0 & 0 & 0 & 0 & 0 \\
\hline $\mathrm{K} 2 \mathrm{O}$ & 0 & 0 & 0 & 0 & 0 & 0 & 0 & 0 & 0 & 0 & 0 & 0 & 0 & 0 & 0 \\
\hline Totals & 101,21 & 101,39 & 102 & 100,9 & 101,04 & 101,21 & 101,03 & 101,45 & 100,97 & 101,3 & 100,84 & 100,78 & 100,62 & 102,05 & 99,81 \\
\hline Oxygens & 12 & 12 & 12 & 12 & 12 & 12 & 12 & 12 & 12 & 12 & 12 & 12 & 12 & 12 & 12 \\
\hline $\mathrm{Si}$ & 3,006 & 3,004 & 2,96 & 2,999 & 2,992 & 2,992 & 3,002 & 2,983 & 2,989 & 3,009 & 3,008 & 3,013 & 3,006 & 2,99 & 2,973 \\
\hline $\mathrm{Ti}$ & 0,004 & 0,003 & 0,003 & 0,005 & 0,002 & 0,001 & 0,005 & 0,006 & 0,006 & 0,005 & 0,003 & 0,004 & 0,004 & 0 & 0,003 \\
\hline $\mathrm{Al}$ & 1,99 & 2 & 2,015 & 2,014 & 2 & 2,009 & 1,993 & 1,986 & 2,02 & 1,992 & 1,979 & 2,004 & 1,988 & 2,014 & 1,954 \\
\hline $\mathrm{Cr}$ & 0 & 0 & 0 & 0 & 0 & 0 & 0 & 0 & 0 & 0 & 0 & 0 & 0 & 0 & 0 \\
\hline $\mathrm{Fe} 3$ & 0 & 0 & 0,058 & 0 & 0,012 & 0,007 & 0 & 0,036 & 0 & 0 & 0 & 0 & 0 & 0,005 & 0,093 \\
\hline $\mathrm{Fe} 2$ & 1,668 & 1,627 & 1,58 & 1,582 & 1,604 & 1,587 & 1,625 & 1,605 & 1,643 & 1,726 & 1,716 & 1,612 & 1,628 & 1,669 & 1,697 \\
\hline $\mathrm{Mn}$ & 0,279 & 0,289 & 0,281 & 0,288 & 0,283 & 0,281 & 0,286 & 0,292 & 0,288 & 0,289 & 0,292 & 0,289 & 0,29 & 0,283 & 0,296 \\
\hline $\mathrm{Mg}$ & 0,576 & 0,625 & 0,659 & 0,649 & 0,655 & 0,671 & 0,639 & 0,642 & 0,604 & 0,532 & 0,552 & 0,6 & 0,622 & 0,588 & 0,537 \\
\hline $\mathrm{Ca}$ & 0,47 & 0,445 & 0,444 & 0,452 & 0,452 & 0,452 & 0,447 & 0,449 & 0,445 & 0,439 & 0,45 & 0,46 & 0,457 & 0,45 & 0,447 \\
\hline $\mathrm{Na}$ & 0 & 0 & 0 & 0 & 0 & 0 & 0 & 0 & 0 & 0 & 0 & 0 & 0 & 0 & 0 \\
\hline K & 0 & 0 & 0 & 0 & 0 & 0 & 0 & 0 & 0 & 0 & 0 & 0 & 0 & 0 & 0 \\
\hline Sum & 7,994 & 7,993 & 8 & 7,99 & 8 & 8 & 7,997 & 8 & 7,995 & 7,991 & 8 & 7,981 & 7,996 & 8 & 8 \\
\hline
\end{tabular}


ALFE45i - Granada

\begin{tabular}{|c|c|c|c|c|c|c|c|c|c|c|c|c|c|c|}
\hline Sample & 501 & 502 & 503 & 504 & 505 & 506 & 507 & 508 & 509 & 510 & 511 & 512 & 513 & 514 \\
\hline Min & g & $\mathrm{g}$ & $\mathrm{g}$ & $\mathrm{g}$ & $\mathrm{g}$ & $\mathrm{g}$ & $\mathrm{g}$ & $\mathrm{g}$ & $\mathrm{g}$ & g & g & $\mathrm{g}$ & g & $\mathrm{g}$ \\
\hline $\mathrm{SiO} 2$ & 38,47 & 38,73 & 38,82 & 38,59 & 38,61 & 38,69 & 39,06 & 39,07 & 38,29 & 38,91 & 38,54 & 38,73 & 39,22 & 38,59 \\
\hline $\mathrm{TiO} 2$ & 0,06 & 0 & 0,07 & 0,05 & 0,07 & 0,06 & 0,06 & 0,07 & 0,05 & 0 & 0,06 & 0,05 & 0,04 & 0,02 \\
\hline $\mathrm{A} 12 \mathrm{O} 3$ & 21,67 & 21,97 & 22,01 & 22,37 & 22,13 & 22,31 & 22,16 & 22,33 & 21,76 & 22,05 & 21,97 & 21,46 & 21,83 & 21,75 \\
\hline $\mathrm{Cr} 2 \mathrm{O} 3$ & 0 & 0 & 0 & 0 & 0 & 0 & 0 & 0 & 0 & 0 & 0 & 0 & 0 & 0 \\
\hline $\mathrm{Fe} 2 \mathrm{O} 3$ & 0 & 0 & 0,36 & 0,4 & 0,35 & 0,23 & 0,43 & 0,18 & 0,97 & 0 & 0,22 & 0 & 0 & 0 \\
\hline $\mathrm{FeO}$ & 25,65 & 24,81 & 24,95 & 24,97 & 24,68 & 24,7 & 24,9 & 25,25 & 24,24 & 24,82 & 25,69 & 25,95 & 26,27 & 25,81 \\
\hline $\mathrm{MnO}$ & 4,55 & 4,5 & 4,39 & 4,4 & 4,31 & 4,21 & 4,23 & 4,22 & 4,42 & 4,39 & 4,46 & 4,46 & 4,4 & 4,37 \\
\hline $\mathrm{MgO}$ & 5,06 & 5,33 & 5,62 & 5,59 & 5,71 & 5,75 & 5,94 & 5,72 & 5,69 & 5,54 & 5,06 & 4,71 & 4,74 & 4,73 \\
\hline $\mathrm{CaO}$ & 5,3 & 5,35 & 5,51 & 5,31 & 5,46 & 5,54 & 5,45 & 5,5 & 5,43 & 5,43 & 5,39 & 5,54 & 5,27 & 5,78 \\
\hline $\mathrm{Na} 2 \mathrm{O}$ & 0 & 0 & 0 & 0 & 0 & 0 & 0 & 0 & 0 & 0 & 0 & 0 & 0 & 0 \\
\hline $\mathrm{K} 2 \mathrm{O}$ & 0 & 0 & 0 & 0 & 0 & 0 & 0 & 0 & 0 & 0 & 0 & 0 & 0 & 0 \\
\hline Totals & 100,77 & 100,7 & 101,74 & 101,69 & 101,32 & 101,48 & 102,25 & 102,34 & 100,84 & 101,14 & 101,39 & 100,9 & 101,77 & 101,06 \\
\hline Oxygens & 12 & 12 & 12 & 12 & 12 & 12 & 12 & 12 & 12 & 12 & 12 & 12 & 12 & 12 \\
\hline $\mathrm{Si}$ & 3,001 & 3,007 & 2,987 & 2,971 & 2,979 & 2,978 & 2,986 & 2,985 & 2,973 & 3,006 & 2,987 & 3,019 & 3,027 & 3,003 \\
\hline $\mathrm{Ti}$ & 0,004 & 0 & 0,004 & 0,003 & 0,004 & 0,003 & 0,004 & 0,004 & 0,003 & 0 & 0,003 & 0,003 & 0,002 & 0,001 \\
\hline $\mathrm{Al}$ & 1,993 & 2,011 & 1,997 & 2,03 & 2,014 & 2,024 & 1,997 & 2,011 & 1,992 & 2,007 & 2,008 & 1,972 & 1,986 & 1,995 \\
\hline $\mathrm{Cr}$ & 0 & 0 & 0 & 0 & 0 & 0 & 0 & 0 & 0 & 0 & 0 & 0 & 0 & 0 \\
\hline $\mathrm{Fe} 3$ & 0 & 0 & 0,021 & 0,023 & 0,02 & 0,013 & 0,024 & 0,01 & 0,056 & 0 & 0,012 & 0 & 0 & 0 \\
\hline $\mathrm{Fe} 2$ & 1,671 & 1,611 & 1,606 & 1,608 & 1,593 & 1,59 & 1,592 & 1,614 & 1,575 & 1,603 & 1,666 & 1,692 & 1,695 & 1,68 \\
\hline $\mathrm{Mn}$ & 0,301 & 0,296 & 0,286 & 0,287 & 0,282 & 0,274 & 0,274 & 0,273 & 0,291 & 0,287 & 0,293 & 0,294 & 0,287 & 0,288 \\
\hline $\mathrm{Mg}$ & 0,588 & 0,616 & 0,645 & 0,641 & 0,657 & 0,66 & 0,677 & 0,651 & 0,658 & 0,637 & 0,584 & 0,547 & 0,545 & 0,549 \\
\hline $\mathrm{Ca}$ & 0,443 & 0,445 & 0,454 & 0,438 & 0,452 & 0,457 & 0,446 & 0,451 & 0,452 & 0,45 & 0,447 & 0,463 & 0,436 & 0,482 \\
\hline $\mathrm{Na}$ & 0 & 0 & 0 & 0 & 0 & 0 & 0 & 0 & 0 & 0 & 0 & 0 & 0 & 0 \\
\hline $\mathrm{K}$ & 0 & 0 & 0 & 0 & 0 & 0 & 0 & 0 & 0 & 0 & 0 & 0 & 0 & 0 \\
\hline Sum & 8 & 7,987 & 8 & 8 & 8 & 8 & 8 & 8 & 8 & 7,991 & 8 & 7,991 & 7,978 & 7,998 \\
\hline
\end{tabular}


ALFE45i - Piroxênio

\begin{tabular}{|c|c|c|c|c|c|c|c|c|c|c|c|c|c|c|c|c|c|c|c|c|c|}
\hline Sample & 101 & 102 & 103 & 201 & 202 & 203 & 204 & 301 & 302 & 303 & 401 & 402 & 403 & 404 & 405 & 406 & 407 & 408 & 409 & 410 & 411 \\
\hline Min & opx & opx & opx & opx & opx & opx & opx & opx & opx & opx & opx & opx & opx & opx & opx & opx & opx & opx & opx & opx & opx \\
\hline $\mathrm{SiO} 2$ & 50,95 & 51,36 & 50,74 & 50,86 & 51,2 & 51,23 & 51,03 & 50,49 & 49,87 & 50,73 & 50,42 & 50,29 & 50,22 & 49,82 & 50,09 & 50,39 & 50,41 & 50,48 & 50,57 & 50,44 & 50,59 \\
\hline $\mathrm{TiO} 2$ & 0,07 & 0,07 & 0,11 & 0,06 & 0,07 & 0,08 & 0,07 & 0,06 & 0,1 & 0,03 & 0,09 & 0,11 & 0,1 & 0,13 & 0,11 & 0,12 & 0,11 & 0,1 & 0,1 & 0,11 & 0,04 \\
\hline $\mathrm{A} 12 \mathrm{O} 3$ & 1,47 & 1,44 & 1,43 & 1,2 & 0,96 & 1,26 & 1,31 & 1,59 & 1,71 & 1,22 & 1,76 & 2,03 & 2,05 & 2,18 & 2,08 & 1,86 & 1,73 & 1,68 & 1,84 & 1,72 & 1,51 \\
\hline $\mathrm{Cr} 2 \mathrm{O} 3$ & 0 & 0 & 0 & 0 & 0 & 0 & 0 & 0 & 0 & 0 & 0 & 0 & 0 & 0 & 0 & 0 & 0 & 0 & 0 & 0 & 0 \\
\hline $\mathrm{Fe} 2 \mathrm{O} 3$ & 1,44 & 1,03 & 2,39 & 2,43 & 2,09 & 1,76 & 2 & 1,24 & 2,62 & 2,37 & 1,68 & 1,28 & 1,26 & 1,97 & 0,96 & 2,08 & 1,44 & 2,02 & 1,47 & 1,48 & 1,57 \\
\hline $\mathrm{FeO}$ & 26,75 & 27,24 & 26,08 & 26,02 & 26,45 & 26,57 & 26,67 & 26,61 & 25,8 & 26,24 & 26,61 & 27,09 & 26,64 & 26,15 & 26,75 & 26,56 & 26,8 & 26,45 & 26,64 & 26,53 & 26,58 \\
\hline $\mathrm{MnO}$ & 1,46 & 1,46 & 1,56 & 1,44 & 1,47 & 1,55 & 1,34 & 1,49 & 1,53 & 1,49 & 1,84 & 1,86 & 1,83 & 1,8 & 1,8 & 1,83 & 1,8 & 1,81 & 1,83 & 1,83 & 1,81 \\
\hline $\mathrm{MgO}$ & 17,96 & 17,93 & 18,07 & 18,28 & 18,29 & 18,11 & 18,22 & 17,7 & 17,65 & 18,04 & 17,14 & 16,96 & 17,19 & 16,79 & 17,01 & 17,38 & 17,16 & 17,53 & 17,26 & 17,4 & 17,53 \\
\hline $\mathrm{CaO}$ & 0,58 & 0,63 & 0,69 & 0,56 & 0,59 & 0,65 & 0,42 & 0,59 & 0,71 & 0,57 & 0,91 & 0,81 & 0,79 & 1,2 & 0,86 & 0,73 & 0,91 & 0,73 & 0,98 & 0,72 & 0,66 \\
\hline $\mathrm{Na} 2 \mathrm{O}$ & 0 & 0 & 0 & 0,02 & 0 & 0,02 & 0,01 & 0 & 0 & 0,01 & 0,04 & 0 & 0 & 0,05 & 0 & 0,01 & 0 & 0 & 0,01 & 0,02 & 0 \\
\hline $\mathrm{K} 2 \mathrm{O}$ & 0 & 0 & 0 & 0 & 0 & 0 & 0 & 0 & 0 & 0 & 0 & 0 & 0 & 0 & 0 & 0 & 0 & 0 & 0 & 0 & 0 \\
\hline Totals & 100,68 & 101,16 & 101,08 & 100,86 & 101,11 & 101,22 & 101,07 & 99,77 & 100 & 100,69 & 100,49 & 100,42 & 100,07 & 100,09 & 99,65 & 100,95 & 100,38 & 100,79 & 100,7 & 100,25 & 100,3 \\
\hline Oxygens & 6 & 6 & 6 & 6 & 6 & 6 & 6 & 6 & 6 & 6 & 6 & 6 & 6 & 6 & 6 & 6 & 6 & 6 & 6 & 6 & 6 \\
\hline $\mathrm{Si}$ & 1,944 & 1,951 & 1,931 & 1,937 & 1,947 & 1,945 & 1,94 & 1,944 & 1,92 & 1,938 & 1,935 & 1,932 & 1,932 & 1,92 & 1,935 & 1,925 & 1,937 & 1,93 & 1,935 & 1,937 & 1,942 \\
\hline $\mathrm{Ti}$ & 0,002 & 0,002 & 0,003 & 0,002 & 0,002 & 0,002 & 0,002 & 0,002 & 0,003 & 0,001 & 0,003 & 0,003 & 0,003 & 0,004 & 0,003 & 0,003 & 0,003 & 0,003 & 0,003 & 0,003 & 0,001 \\
\hline $\mathrm{Al}$ & 0,066 & 0,064 & 0,064 & 0,054 & 0,043 & 0,056 & 0,059 & 0,072 & 0,077 & 0,055 & 0,08 & 0,092 & 0,093 & 0,099 & 0,095 & 0,084 & 0,078 & 0,076 & 0,083 & 0,078 & 0,068 \\
\hline $\mathrm{Cr}$ & 0 & 0 & 0 & 0 & 0 & 0 & 0 & 0 & 0 & 0 & 0 & 0 & 0 & 0 & 0 & 0 & 0 & 0 & 0 & 0 & 0 \\
\hline $\mathrm{Fe} 3$ & 0,041 & 0,03 & 0,069 & 0,07 & 0,06 & 0,05 & 0,057 & 0,036 & 0,076 & 0,068 & 0,048 & 0,037 & 0,037 & 0,057 & 0,028 & 0,06 & 0,042 & 0,058 & 0,042 & 0,043 & 0,045 \\
\hline $\mathrm{Fe} 2$ & 0,854 & 0,865 & 0,83 & 0,829 & 0,841 & 0,844 & 0,848 & 0,857 & 0,831 & 0,838 & 0,854 & 0,871 & 0,858 & 0,843 & 0,865 & 0,848 & 0,861 & 0,846 & 0,852 & 0,852 & 0,853 \\
\hline $\mathrm{Mn}$ & 0,047 & 0,047 & 0,05 & 0,046 & 0,047 & 0,05 & 0,043 & 0,049 & 0,05 & 0,048 & 0,06 & 0,061 & 0,06 & 0,059 & 0,059 & 0,059 & 0,059 & 0,058 & 0,059 & 0,06 & 0,059 \\
\hline $\mathrm{Mg}$ & 1,022 & 1,015 & 1,025 & 1,038 & 1,036 & 1,025 & 1,033 & 1,016 & 1,013 & 1,027 & 0,98 & 0,971 & 0,986 & 0,965 & 0,98 & 0,989 & 0,983 & 0,999 & 0,984 & 0,996 & 1,003 \\
\hline $\mathrm{Ca}$ & 0,024 & 0,026 & 0,028 & 0,023 & 0,024 & 0,026 & 0,017 & 0,024 & 0,029 & 0,023 & 0,037 & 0,033 & 0,032 & 0,05 & 0,036 & 0,03 & 0,038 & 0,03 & 0,04 & 0,03 & 0,027 \\
\hline $\mathrm{Na}$ & 0 & 0 & 0 & 0,002 & 0 & 0,001 & 0,001 & 0 & 0 & 0,001 & 0,003 & 0 & 0 & 0,004 & 0 & 0,001 & 0 & 0 & 0,001 & 0,001 & 0 \\
\hline K & 0 & 0 & 0 & 0 & 0 & 0 & 0 & 0 & 0 & 0 & 0 & 0 & 0 & 0 & 0 & 0 & 0 & 0 & 0 & 0 & 0 \\
\hline Sum & 4 & 4 & 4 & 4 & 4 & 4 & 4 & 4 & 4 & 4 & 4 & 4 & 4 & 4 & 4 & 4 & 4 & 4 & 4 & 4 & 4 \\
\hline
\end{tabular}


ALFE45i - Piroxênio

\begin{tabular}{|c|c|c|c|c|c|c|c|c|c|c|}
\hline Sample & 501 & 502 & 503 & 504 & 505 & 601 & 602 & 603 & 604 & 605 \\
\hline Min & opx & opx & opx & opx & opx & opx & opx & opx & opx & opx \\
\hline $\mathrm{SiO} 2$ & 49,63 & 50,37 & 50,45 & 50,44 & 50,5 & 50,62 & 50,27 & 50,62 & 50,43 & 50,75 \\
\hline $\mathrm{TiO} 2$ & 0,09 & 0,09 & 0,06 & 0,09 & 0,07 & 0,1 & 0,11 & 0,1 & 0,1 & 0,1 \\
\hline $\mathrm{Al} 2 \mathrm{O} 3$ & 1,73 & 1,73 & 1,47 & 1,88 & 1,56 & 1,71 & 1,59 & 1,69 & 1,91 & 1,62 \\
\hline $\mathrm{Cr} 2 \mathrm{O} 3$ & 0 & 0 & 0 & 0 & 0 & 0 & 0 & 0 & 0 & 0 \\
\hline $\mathrm{Fe} 2 \mathrm{O} 3$ & 2,57 & 1,5 & 2,25 & 1,13 & 1,71 & 1,75 & 2,08 & 2,11 & 2,27 & 1,45 \\
\hline $\mathrm{FeO}$ & 25,37 & 26,57 & 25,84 & 26,85 & 25,93 & 26,59 & 25,87 & 26,16 & 26,21 & 27,03 \\
\hline $\mathrm{MnO}$ & 1,67 & 1,64 & 1,7 & 1,72 & 1,69 & 1,64 & 1,68 & 1,63 & 1,62 & 1,58 \\
\hline $\mathrm{MgO}$ & 17,61 & 17,38 & 17,88 & 17,36 & 17,95 & 17,67 & 17,77 & 17,87 & 17,77 & 17,5 \\
\hline $\mathrm{CaO}$ & 0,71 & 0,72 & 0,69 & 0,68 & 0,56 & 0,63 & 0,73 & 0,71 & 0,67 & 0,61 \\
\hline $\mathrm{Na} 2 \mathrm{O}$ & 0,01 & 0,04 & 0,02 & 0 & 0,02 & 0,01 & 0,01 & 0,01 & 0 & 0,03 \\
\hline $\mathrm{K} 2 \mathrm{O}$ & 0 & 0 & 0 & 0 & 0 & 0 & 0 & 0 & 0 & 0 \\
\hline Totals & 99,39 & 100,05 & 100,35 & 100,14 & 99,99 & 100,73 & 100,1 & 100,91 & 100,98 & 100,68 \\
\hline Oxygens & 6 & 6 & 6 & 6 & 6 & 6 & 6 & 6 & 6 & 6 \\
\hline $\mathrm{Si}$ & 1,921 & 1,938 & 1,933 & 1,939 & 1,939 & 1,934 & 1,931 & 1,929 & 1,922 & 1,941 \\
\hline $\mathrm{Ti}$ & 0,003 & 0,003 & 0,002 & 0,002 & 0,002 & 0,003 & 0,003 & 0,003 & 0,003 & 0,003 \\
\hline $\mathrm{Al}$ & 0,079 & 0,078 & 0,066 & 0,085 & 0,071 & 0,077 & 0,072 & 0,076 & 0,086 & 0,073 \\
\hline $\mathrm{Cr}$ & 0 & 0 & 0 & 0 & 0 & 0 & 0 & 0 & 0 & 0 \\
\hline $\mathrm{Fe} 3$ & 0,075 & 0,043 & 0,065 & 0,033 & 0,049 & 0,05 & 0,06 & 0,061 & 0,065 & 0,042 \\
\hline $\mathrm{Fe} 2$ & 0,821 & 0,855 & 0,828 & 0,863 & 0,833 & 0,85 & 0,831 & 0,834 & 0,835 & 0,865 \\
\hline $\mathrm{Mn}$ & 0,055 & 0,053 & 0,055 & 0,056 & 0,055 & 0,053 & 0,055 & 0,053 & 0,052 & 0,051 \\
\hline $\mathrm{Mg}$ & 1,016 & 0,997 & 1,021 & 0,994 & 1,027 & 1,006 & 1,017 & 1,015 & 1,009 & 0,998 \\
\hline $\mathrm{Ca}$ & 0,029 & 0,03 & 0,028 & 0,028 & 0,023 & 0,026 & 0,03 & 0,029 & 0,028 & 0,025 \\
\hline $\mathrm{Na}$ & 0,001 & 0,003 & 0,001 & 0 & 0,001 & 0,001 & 0,001 & 0,001 & 0 & 0,002 \\
\hline $\mathrm{K}$ & 0 & 0 & 0 & 0 & 0 & 0 & 0 & 0 & 0 & 0 \\
\hline Sum & 4 & 4 & 4 & 4 & 4 & 4 & 4 & 4 & 4 & 4 \\
\hline
\end{tabular}


ALFE45i - Plagioclásio

\begin{tabular}{|c|c|c|c|c|c|c|c|c|c|c|c|c|c|c|c|c|c|c|c|}
\hline Sample & 101 & 102 & 103 & 104 & 105 & 201 & 202 & 203 & 204 & 205 & 301 & 302 & 303 & 304 & 401 & 402 & 403 & 404 & 405 \\
\hline Min & fsp & fsp & fsp & fsp & fsp & fsp & fsp & fsp & fsp & fsp & $\mathrm{fsp}$ & fsp & fsp & fsp & fsp & fsp & fsp & fsp & $\mathrm{fsp}$ \\
\hline $\mathrm{SiO} 2$ & 62,71 & 62,19 & 62,06 & 61,83 & 62,46 & 62,52 & 62,05 & 62,24 & 61,1 & 61,81 & 59,22 & 61,34 & 61,64 & 61,45 & 61,95 & 62,1 & 62,27 & 60,89 & 61,57 \\
\hline $\mathrm{TiO} 2$ & 0 & 0 & 0 & 0 & 0 & 0 & 0 & 0 & 0 & 0 & 0 & 0 & 0 & 0 & 0 & 0 & 0 & 0 & 0 \\
\hline $\mathrm{A} 12 \mathrm{O} 3$ & 23,46 & 24,02 & 23,73 & 23,79 & 23,62 & 23,82 & 23,63 & 23,38 & 23,76 & 23,7 & 22,48 & 23,89 & 24,21 & 23,96 & 24,2 & 23,88 & 23,86 & 24,05 & 23,86 \\
\hline $\mathrm{Cr} 2 \mathrm{O} 3$ & 0 & 0 & 0 & 0 & 0 & 0 & 0 & 0 & 0 & 0 & 0 & 0 & 0 & 0 & 0 & 0 & 0 & 0 & 0 \\
\hline $\mathrm{Fe} 2 \mathrm{O} 3$ & 0 & 0 & 0 & 0 & 0 & 0 & 0 & 0 & 0 & 0 & 0 & 0 & 0 & 0 & 0 & 0 & 0 & 0 & 0 \\
\hline $\mathrm{FeO}$ & 0 & 0 & 0 & 0 & 0 & 0 & 0 & 0 & 0 & 0 & 0 & 0 & 0 & 0 & 0 & 0 & 0 & 0 & 0 \\
\hline $\mathrm{MnO}$ & 0 & 0 & 0 & 0 & 0 & 0 & 0 & 0 & 0 & 0 & 0 & 0 & 0 & 0 & 0 & 0 & 0 & 0 & 0 \\
\hline $\mathrm{MgO}$ & 0 & 0 & 0 & 0 & 0 & 0 & 0 & 0 & 0 & 0 & 0 & 0 & 0 & 0 & 0 & 0 & 0 & 0 & 0 \\
\hline $\mathrm{CaO}$ & 6,02 & 6,11 & 6,16 & 6,23 & 6,02 & 6,02 & 6,31 & 6,16 & 6,12 & 5,91 & 6,03 & 6,31 & 6,46 & 6,36 & 6,39 & 6,23 & 6,42 & 6,36 & 6,37 \\
\hline $\mathrm{Na} 2 \mathrm{O}$ & 8,18 & 8,22 & 7,96 & 7,91 & 7,54 & 7,88 & 7,89 & 7,85 & 7,85 & 7,99 & 7,24 & 7,59 & 7,65 & 7,63 & 7,63 & 7,71 & 7,67 & 7,28 & 7,09 \\
\hline $\mathrm{K} 2 \mathrm{O}$ & 0,2 & 0,23 & 0,26 & 0,3 & 0,26 & 0,51 & 0,42 & 0,43 & 0,36 & 0,27 & 0,28 & 0,44 & 0,4 & 0,4 & 0,47 & 0,5 & 0,47 & 0,4 & 0,31 \\
\hline Totals & 100,57 & 100,77 & 100,16 & 100,06 & 99,9 & 100,74 & 100,3 & 100,07 & 99,19 & 99,68 & 95,27 & 99,57 & 100,35 & 99,79 & 100,64 & 100,41 & 100,69 & 98,98 & 99,21 \\
\hline Oxygens & 8 & 8 & 8 & 8 & 8 & 8 & 8 & 8 & 8 & 8 & 8 & 8 & 8 & 8 & 8 & 8 & 8 & 8 & 8 \\
\hline $\mathrm{Si}$ & 2,764 & 2,74 & 2,748 & 2,741 & 2,763 & 2,748 & 2,748 & 2,76 & 2,736 & 2,749 & 2,716 & 2,736 & 2,728 & 2,733 & 2,73 & 2,745 & 2,746 & 2,726 & 2,745 \\
\hline $\mathrm{Ti}$ & 0 & 0 & 0 & 0 & 0 & 0 & 0 & 0 & 0 & 0 & 0 & 0 & 0 & 0 & 0 & 0 & 0 & 0 & 0 \\
\hline $\mathrm{Al}$ & 1,219 & 1,247 & 1,238 & 1,243 & 1,231 & 1,234 & 1,234 & 1,222 & 1,254 & 1,243 & 1,216 & 1,257 & 1,263 & 1,256 & 1,258 & 1,244 & 1,24 & 1,269 & 1,254 \\
\hline $\mathrm{Cr}$ & 0 & 0 & 0 & 0 & 0 & 0 & 0 & 0 & 0 & 0 & 0 & 0 & 0 & 0 & 0 & 0 & 0 & 0 & 0 \\
\hline $\mathrm{Fe} 3$ & 0,003 & 0,003 & 0,004 & 0,005 & 0,008 & 0,013 & 0,002 & 0,003 & 0,002 & 0,003 & 0,079 & 0 & 0,002 & 0,005 & 0,008 & 0,002 & 0,002 & 0,008 & 0,006 \\
\hline $\mathrm{Fe} 2$ & 0 & 0 & 0 & 0 & 0 & 0 & 0 & 0 & 0 & 0 & 0 & 0 & 0 & 0 & 0 & 0 & 0 & 0 & 0 \\
\hline $\mathrm{Mn}$ & 0 & 0 & 0 & 0 & 0 & 0 & 0 & 0 & 0 & 0 & 0 & 0 & 0 & 0 & 0 & 0 & 0 & 0 & 0 \\
\hline $\mathrm{Mg}$ & 0 & 0 & 0 & 0 & 0 & 0 & 0 & 0 & 0 & 0 & 0 & 0 & 0 & 0 & 0 & 0 & 0 & 0 & 0 \\
\hline $\mathrm{Ca}$ & 0,284 & 0,288 & 0,292 & 0,296 & 0,285 & 0,283 & 0,3 & 0,293 & 0,294 & 0,282 & 0,296 & 0,302 & 0,306 & 0,303 & 0,302 & 0,295 & 0,303 & 0,305 & 0,304 \\
\hline $\mathrm{Na}$ & 0,699 & 0,702 & 0,683 & 0,68 & 0,647 & 0,671 & 0,677 & 0,675 & 0,682 & 0,689 & 0,644 & 0,657 & 0,656 & 0,658 & 0,652 & 0,661 & 0,656 & 0,632 & 0,613 \\
\hline K & 0,011 & 0,013 & 0,015 & 0,017 & 0,014 & 0,028 & 0,024 & 0,025 & 0,021 & 0,015 & 0,017 & 0,025 & 0,022 & 0,023 & 0,026 & 0,028 & 0,027 & 0,023 & 0,018 \\
\hline Sum & 4,98 & 4,993 & 4,98 & 4,983 & 4,948 & 4,977 & 4,985 & 4,977 & 4,988 & 4,98 & 4,962 & 4,976 & 4,978 & 4,977 & 4,975 & 4,976 & 4,974 & 4,962 & 4,94 \\
\hline
\end{tabular}


ALFE45i - Plagioclásio

\begin{tabular}{|c|c|c|c|c|c|c|c|c|c|c|c|c|c|c|c|c|c|c|c|c|c|c|c|}
\hline Sample & 501 & 502 & 503 & 504 & 505 & 506 & 601 & 602 & 603 & 604 & 605 & 701 & 702 & 703 & 704 & 801 & 802 & 803 & 804 & 901 & 902 & 903 & 904 \\
\hline Min & $\mathrm{fsp}$ & $\mathrm{fsp}$ & $\mathrm{fsp}$ & fsp & fsp & $\mathrm{fsp}$ & $\mathrm{fsp}$ & $\mathrm{fsp}$ & $\mathrm{fsp}$ & fsp & fsp & fsp & fsp & fsp & fsp & $\mathrm{fsp}$ & fsp & fsp & fsp & fsp & $\mathrm{fsp}$ & fsp & fsp \\
\hline $\mathrm{SiO} 2$ & 61,34 & 60,74 & 61,36 & 62,16 & 62,01 & 61,93 & 61,87 & 61,1 & 61,58 & 61,47 & 62,65 & 62,53 & 60,81 & 62,56 & 59,23 & 62,14 & 61,93 & 61,67 & 62,44 & 61,38 & 62,88 & 62,19 & 62,32 \\
\hline $\mathrm{TiO} 2$ & 0 & 0 & 0 & 0 & 0 & 0 & 0 & 0 & 0 & 0 & 0 & 0 & 0 & 0 & 0 & 0 & 0 & 0 & 0 & 0 & 0 & 0 & 0 \\
\hline $\mathrm{A} 12 \mathrm{O} 3$ & 23,93 & 24 & 23,95 & 23,94 & 24,41 & 23,95 & 24,27 & 23,7 & 23,7 & 23,58 & 23,15 & 23,74 & 23,73 & 23,95 & 21,78 & 23,94 & 23,78 & 24,05 & 23,98 & 23,87 & 23,75 & 23,76 & 23,91 \\
\hline $\mathrm{Cr} 2 \mathrm{O} 3$ & 0 & 0 & 0 & 0 & 0 & 0 & 0 & 0 & 0 & 0 & 0 & 0 & 0 & 0 & 0 & 0 & 0 & 0 & 0 & 0 & 0 & 0 & 0 \\
\hline $\mathrm{Fe} 2 \mathrm{O} 3$ & 0 & 0 & 0 & 0 & 0 & 0 & 0 & 0 & 0 & 0 & 0 & 0 & 0 & 0 & 0 & 0 & 0 & 0 & 0 & 0 & 0 & 0 & 0 \\
\hline $\mathrm{FeO}$ & 0 & 0 & 0 & 0 & 0 & 0 & 0 & 0 & 0 & 0 & 0 & 0 & 0 & 0 & 0 & 0 & 0 & 0 & 0 & 0 & 0 & 0 & 0 \\
\hline $\mathrm{MnO}$ & 0 & 0 & 0 & 0 & 0 & 0 & 0 & 0 & 0 & 0 & 0 & 0 & 0 & 0 & 0 & 0 & 0 & 0 & 0 & 0 & 0 & 0 & 0 \\
\hline $\mathrm{MgO}$ & 0 & 0 & 0 & 0 & 0 & 0 & 0 & 0 & 0 & 0 & 0 & 0 & 0 & 0 & 0 & 0 & 0 & 0 & 0 & 0 & 0 & 0 & 0 \\
\hline $\mathrm{CaO}$ & 6,43 & 6,35 & 6,4 & 6,5 & 6,44 & 6,45 & 6,44 & 6,37 & 6,23 & 6 & 5,67 & 6,27 & 6,2 & 6,28 & 5,4 & 6,35 & 6,21 & 6,44 & 6,32 & 6,17 & 6,19 & 6,23 & 6,26 \\
\hline $\mathrm{Na} 2 \mathrm{O}$ & 7,81 & 7,66 & 7,68 & 7,64 & 7,6 & 7,71 & 7,42 & 7,07 & 7,67 & 7,68 & 8,1 & 7,4 & 7,64 & 7,83 & 6,95 & 7,71 & 7,78 & 7,62 & 7,67 & 7,38 & 7,68 & 7,49 & 7,27 \\
\hline $\mathrm{K} 2 \mathrm{O}$ & 0,28 & 0,3 & 0,28 & 0,26 & 0,29 & 0,27 & 0,37 & 0,4 & 0,35 & 0,29 & 0,2 & 0,43 & 0,39 & 0,33 & 0,22 & 0,28 & 0,3 & 0,27 & 0,21 & 0,56 & 0,53 & 0,53 & 0,54 \\
\hline Totals & 99,79 & 99,06 & 99,67 & 100,51 & 100,75 & 100,31 & 100,37 & 98,64 & 99,53 & 99,03 & 99,77 & 100,37 & 98,77 & 100,95 & 93,58 & 100,42 & 100,01 & 100,04 & 100,63 & 99,37 & 101,03 & 100,2 & 100,3 \\
\hline Oxygens & 8 & 8 & 8 & 8 & 8 & 8 & 8 & 8 & 8 & 8 & 8 & 8 & 8 & 8 & 8 & 8 & 8 & 8 & 8 & 8 & 8 & 8 & 8 \\
\hline $\mathrm{Si}$ & 2,728 & 2,723 & 2,73 & 2,743 & 2,73 & 2,739 & 2,722 & 2,741 & 2,745 & 2,75 & 2,779 & 2,756 & 2,733 & 2,748 & 2,737 & 2,743 & 2,747 & 2,735 & 2,749 & 2,739 & 2,76 & 2,752 & 2,737 \\
\hline $\mathrm{Ti}$ & 0 & 0 & 0 & 0 & 0 & 0 & 0 & 0 & 0 & 0 & 0 & 0 & 0 & 0 & 0 & 0 & 0 & 0 & 0 & 0 & 0 & 0 & 0 \\
\hline $\mathrm{Al}$ & 1,255 & 1,269 & 1,257 & 1,246 & 1,267 & 1,249 & 1,259 & 1,254 & 1,246 & 1,244 & 1,211 & 1,233 & 1,257 & 1,24 & 1,186 & 1,246 & 1,243 & 1,258 & 1,244 & 1,256 & 1,229 & 1,24 & 1,238 \\
\hline $\mathrm{Cr}$ & 0 & 0 & 0 & 0 & 0 & 0 & 0 & 0 & 0 & 0 & 0 & 0 & 0 & 0 & 0 & 0 & 0 & 0 & 0 & 0 & 0 & 0 & 0 \\
\hline $\mathrm{Fe} 3$ & 0,007 & 0,003 & 0,006 & 0,002 & 0,001 & 0,004 & 0,026 & 0,007 & 0,002 & 0,003 & 0,002 & 0,01 & 0,003 & 0,004 & 0,108 & 0,005 & 0,002 & 0,001 & 0,003 & 0,005 & 0,003 & 0,003 & 0,033 \\
\hline $\mathrm{Fe} 2$ & 0 & 0 & 0 & 0 & 0 & 0 & 0 & 0 & 0 & 0 & 0 & 0 & 0 & 0 & 0 & 0 & 0 & 0 & 0 & 0 & 0 & 0 & 0 \\
\hline Mn & 0 & 0 & 0 & 0 & 0 & 0 & 0 & 0 & 0 & 0 & 0 & 0 & 0 & 0 & 0 & 0 & 0 & 0 & 0 & 0 & 0 & 0 & 0 \\
\hline $\mathrm{Mg}$ & 0 & 0 & 0 & 0 & 0 & 0 & 0 & 0 & 0 & 0 & 0 & 0 & 0 & 0 & 0 & 0 & 0 & 0 & 0 & 0 & 0 & 0 & 0 \\
\hline $\mathrm{Ca}$ & 0,307 & 0,305 & 0,305 & 0,307 & 0,304 & 0,305 & 0,304 & 0,306 & 0,298 & 0,288 & 0,269 & 0,296 & 0,299 & 0,295 & 0,268 & 0,3 & 0,295 & 0,306 & 0,298 & 0,295 & 0,291 & 0,296 & 0,295 \\
\hline $\mathrm{Na}$ & 0,673 & 0,666 & 0,663 & 0,654 & 0,649 & 0,661 & 0,633 & 0,615 & 0,663 & 0,667 & 0,697 & 0,633 & 0,666 & 0,667 & 0,623 & 0,66 & 0,669 & 0,655 & 0,655 & 0,639 & 0,653 & 0,643 & 0,619 \\
\hline K & 0,016 & 0,017 & 0,016 & 0,015 & 0,017 & 0,015 & 0,021 & 0,023 & 0,02 & 0,017 & 0,011 & 0,024 & 0,023 & 0,019 & 0,013 & 0,016 & 0,017 & 0,015 & 0,012 & 0,032 & 0,03 & 0,03 & 0,03 \\
\hline Sum & 4,985 & 4,983 & 4,977 & 4,967 & 4,968 & 4,973 & 4,961 & 4,947 & 4,972 & 4,968 & 4,969 & 4,951 & 4,98 & 4,972 & 4,926 & 4,969 & 4,974 & 4,971 & 4,961 & 4,966 & 4,966 & 4,963 & 4,95 \\
\hline
\end{tabular}


ALFE45N - Clinopiroxênio

\begin{tabular}{|c|c|c|c|c|c|c|c|c|c|c|c|c|c|c|c|c|c|c|c|c|c|c|c|c|}
\hline Sample & 401 & 402 & 403 & 404 & 405 & 406 & 407 & 408 & 101 & 102 & 103 & 104 & 105 & 201 & 202 & 203 & 204 & 205 & 206 & 301 & 302 & 303 & 304 & 305 \\
\hline Min & cpx & $\mathrm{x}$ & $\mathrm{x}$ & $\mathrm{x}$ & $\mathrm{x}$ & cpx & $\mathrm{x}$ & $\mathrm{x}$ & cpx & cpx & $\mathrm{x}$ & $\mathrm{x}$ & $\mathrm{x}$ & cpx & cpx & $\mathrm{x}$ & $x$ & cpx & cpx & $\mathrm{px}$ & px & cpx & cpx & px \\
\hline $\mathrm{SiO} 2$ & 49,88 & 50,11 & 50,08 & 50,04 & 50,28 & 49,93 & 50,32 & 50,23 & 50,19 & 49,71 & 49,84 & 50,06 & 50,73 & 50,41 & 50,27 & 50,16 & 50,05 & 50,1 & 50,71 & 50,6 & 50,07 & 49,49 & 49,37 & 49,75 \\
\hline $\mathrm{TiO} 2$ & 0,33 & 0,29 & 0,31 & 0,31 & 0,24 & 0,3 & 0,23 & 0,05 & 0,25 & 0,35 & 0,32 & 0,31 & 0,21 & 0,18 & 0,33 & 0,2 & 0,26 & 0,26 & 0,2 & 0,24 & 0,27 & 0,31 & 0,31 & 0,31 \\
\hline $\mathrm{A} 12 \mathrm{O} 3$ & 3,43 & 3,2 & 3,32 & 3,2 & 2,92 & 3,12 & 2,79 & 1,31 & 2,7 & 3,52 & 3,25 & 3,19 & 2,65 & 2,39 & 3,21 & 2,51 & 3,01 & 2,87 & 2,59 & 2,56 & 2,81 & 3,04 & 3,23 & 2,94 \\
\hline $\mathrm{Cr} 2 \mathrm{O} 3$ & 0 & 0 & 0 & 0 & 0 & 0 & 0 & 0 & 0 & 0 & 0 & 0 & 0 & 0 & 0 & 0 & 0 & 0 & 0 & 0 & 0 & 0 & 0 & 0 \\
\hline $\mathrm{Fe} 2 \mathrm{O} 3$ & 4,04 & 3,6 & 4,62 & 4,16 & 5,35 & 3,69 & 4,48 & 2,05 & 4,23 & 4,06 & 4,39 & 4,16 & 3,84 & 3,79 & 3,38 & 4,71 & 4,67 & 3,34 & 3,83 & 3,53 & 4,43 & 4,15 & 4,82 & 4,15 \\
\hline $\mathrm{FeO}$ & 8,55 & 10,55 & 10,08 & 10,15 & 7,37 & 9,68 & 7,92 & 26,16 & 7,74 & 9,09 & 7,81 & 8,31 & 7,67 & 7,44 & 8,46 & 7,03 & 7,25 & 10,19 & 8,47 & 8,81 & 8,59 & 9,26 & 8,06 & 9,08 \\
\hline $\mathrm{MnO}$ & 0,47 & 0,52 & 0,54 & 0,51 & 0,45 & 0,49 & 0,45 & 0,96 & 0,44 & 0,48 & 0,48 & 0,47 & 0,42 & 0,38 & 0,45 & 0,44 & 0,33 & 0,26 & 0,45 & 0,22 & 0,22 & 0,34 & 0,24 & 0,22 \\
\hline $\mathrm{MgO}$ & 11,28 & 12,12 & 12,01 & 11,97 & 11,71 & 11,34 & 11,55 & 18,04 & 11,46 & 11,16 & 11,13 & 11,35 & 11,73 & 11,8 & 11,47 & 11,97 & 11,65 & 11,9 & 11,88 & 11,59 & 11,73 & 11,45 & 11,3 & 11,44 \\
\hline $\mathrm{CaO}$ & 20,83 & 18,55 & 18,79 & 18,94 & 21,63 & 20,12 & 21,49 & 0,57 & 21,8 & 20,5 & 21,41 & 21,1 & 21,86 & 21,96 & 21,05 & 21,64 & 21,59 & 19,37 & 20,97 & 21,38 & 20,8 & 20,09 & 21,17 & 20,68 \\
\hline $\mathrm{Na} 2 \mathrm{O}$ & 0,89 & 0,8 & 0,87 & 0,83 & 0,85 & 0,82 & 0,84 & 0,02 & 0,8 & 0,87 & 0,93 & 0,88 & 0,83 & 0,74 & 0,88 & 0,78 & 0,88 & 0,79 & 0,83 & 0,79 & 0,81 & 0,8 & 0,81 & 0,77 \\
\hline $\mathrm{K} 2 \mathrm{O}$ & 0 & 0 & 0 & 0 & 0 & 0 & 0 & 0 & 0 & 0 & 0 & 0 & 0 & 0 & 0 & 0 & 0 & 0 & 0 & 0 & 0 & 0 & 0 & 0 \\
\hline Totals & 99,71 & 99,75 & 100,62 & 100,1 & 100,79 & 99,48 & 100,06 & 99,4 & 99,61 & 99,75 & 99,57 & 99,84 & 99,94 & 99,09 & 99,51 & 99,44 & 99,68 & 99,08 & 99,94 & 99,73 & 99,73 & 98,93 & 99,31 & 99,35 \\
\hline Oxygens & 6 & 6 & 6 & 6 & 6 & 6 & 6 & 6 & 6 & 6 & 6 & 6 & 6 & 6 & 6 & 6 & 6 & 6 & 6 & 6 & 6 & 6 & 6 & 6 \\
\hline $\mathrm{Si}$ & 1,889 & 1,898 & 1,884 & 1,891 & 1,884 & 1,899 & 1,898 & 1,94 & 1,902 & 1,885 & 1,89 & 1,893 & 1,911 & 1,915 & 1,903 & 1,9 & 1,891 & 1,91 & 1,913 & 1,915 & 1,896 & 1,893 & 1,879 & 1,894 \\
\hline $\mathrm{Ti}$ & 0,009 & 0,008 & 0,009 & 0,009 & 0,007 & 0,009 & 0,006 & 0,002 & 0,007 & 0,01 & 0,009 & 0,009 & 0,006 & 0,005 & 0,009 & 0,006 & 0,007 & 0,007 & 0,006 & 0,007 & 0,008 & 0,009 & 0,009 & 0,009 \\
\hline $\mathrm{Al}$ & 0,153 & 0,143 & 0,147 & 0,143 & 0,129 & 0,14 & 0,124 & 0,06 & 0,121 & 0,158 & 0,145 & 0,142 & 0,118 & 0,107 & 0,143 & 0,112 & 0,134 & 0,129 & 0,115 & 0,114 & 0,125 & 0,137 & 0,145 & 0,132 \\
\hline $\mathrm{Cr}$ & 0 & 0 & 0 & 0 & 0 & 0 & 0 & 0 & 0 & 0 & 0 & 0 & 0 & 0 & 0 & 0 & 0 & 0 & 0 & 0 & 0 & 0 & 0 & 0 \\
\hline $\mathrm{Fe} 3$ & 0,115 & 0,103 & 0,131 & 0,118 & 0,151 & 0,105 & 0,127 & 0,059 & 0,12 & 0,116 & 0,125 & 0,118 & 0,109 & 0,108 & 0,096 & 0,134 & 0,133 & 0,096 & 0,109 & 0,1 & 0,126 & 0,119 & 0,138 & 0,119 \\
\hline $\mathrm{Fe} 2$ & 0,271 & 0,334 & 0,317 & 0,321 & 0,231 & 0,308 & 0,25 & 0,845 & 0,245 & 0,288 & 0,248 & 0,263 & 0,242 & 0,236 & 0,268 & 0,223 & 0,229 & 0,325 & 0,267 & 0,279 & 0,272 & 0,296 & 0,257 & 0,289 \\
\hline $\mathrm{Mn}$ & 0,015 & 0,017 & 0,017 & 0,016 & 0,014 & 0,016 & 0,014 & 0,032 & 0,014 & 0,015 & 0,015 & 0,015 & 0,013 & 0,012 & 0,014 & 0,014 & 0,01 & 0,008 & 0,014 & 0,007 & 0,007 & 0,011 & 0,008 & 0,007 \\
\hline $\mathrm{Mg}$ & 0,637 & 0,684 & 0,673 & 0,674 & 0,654 & 0,643 & 0,649 & 1,038 & 0,647 & 0,631 & 0,629 & 0,64 & 0,659 & 0,668 & 0,647 & 0,676 & 0,656 & 0,676 & 0,668 & 0,653 & 0,662 & 0,652 & 0,641 & 0,649 \\
\hline $\mathrm{Ca}$ & 0,845 & 0,753 & 0,757 & 0,767 & 0,868 & 0,82 & 0,869 & 0,024 & 0,885 & 0,833 & 0,87 & 0,855 & 0,882 & 0,894 & 0,854 & 0,878 & 0,874 & 0,791 & 0,847 & 0,867 & 0,844 & 0,823 & 0,864 & 0,844 \\
\hline $\mathrm{Na}$ & 0,065 & 0,059 & 0,064 & 0,061 & 0,062 & 0,061 & 0,061 & 0,002 & 0,059 & 0,064 & 0,069 & 0,065 & 0,06 & 0,055 & 0,064 & 0,057 & 0,064 & 0,058 & 0,061 & 0,058 & 0,059 & 0,059 & 0,06 & 0,057 \\
\hline K & 0 & 0 & 0 & 0 & 0 & 0 & 0 & 0 & 0 & 0 & 0 & 0 & 0 & 0 & 0 & 0 & 0 & 0 & 0 & 0 & 0 & 0 & 0 & 0 \\
\hline Sum & 4 & 4 & 4 & 4 & 4 & 4 & 4 & 4 & 4 & 4 & 4 & 4 & 4 & 4 & 4 & 4 & 4 & 4 & 4 & 4 & 4 & 4 & 4 & 4 \\
\hline
\end{tabular}


ALFE45N - Ortopiroxênio

\begin{tabular}{|c|c|c|c|c|c|c|c|c|c|c|c|c|c|c|c|c|c|}
\hline Sample & 101 & 102 & 103 & 104 & 105 & 201 & 202 & 203 & 204 & 205 & 206 & 301 & 302 & 303 & 304 & 305 & 306 \\
\hline Min & opx & opx & opx & opx & opx & opx & opx & opx & opx & opx & opx & opx & opx & opx & opx & opx & opx \\
\hline $\mathrm{SiO} 2$ & 50,96 & 51,58 & 51,18 & 51,88 & 51,41 & 51,8 & 51,92 & 51,63 & 51,79 & 51,89 & 51,92 & 52,11 & 51,82 & 51,6 & 51,69 & 52,18 & 52,1 \\
\hline $\mathrm{TiO} 2$ & 0,09 & 0,09 & 0,1 & 0,08 & 0,1 & 0,08 & 0,06 & 0,09 & 0,07 & 0,1 & 0,09 & 0,07 & 0,1 & 0,09 & 0,1 & 0,09 & 0,09 \\
\hline $\mathrm{Al} 2 \mathrm{O} 3$ & 1,23 & 1,32 & 1,52 & 1,43 & 1,49 & 1,04 & 1,52 & 1,44 & 1,45 & 1,3 & 1,18 & 1,16 & 1,39 & 1,49 & 1,48 & 1,09 & 1,06 \\
\hline $\mathrm{Cr} 2 \mathrm{O} 3$ & 0 & 0 & 0 & 0 & 0 & 0 & 0 & 0 & 0 & 0 & 0 & 0 & 0 & 0 & 0 & 0 & 0 \\
\hline $\mathrm{Fe} 2 \mathrm{O} 3$ & 1,46 & 0,36 & 0,37 & 0 & 0,89 & 0 & 0 & 0,19 & 0 & 0,02 & 0 & 0 & 0 & 0 & 0,81 & 0,11 & 0 \\
\hline $\mathrm{FeO}$ & 25,86 & 25,95 & 26,88 & 26,12 & 26,68 & 25,63 & 24,47 & 26,43 & 25,56 & 25,94 & 26,33 & 26,29 & 26,87 & 27,07 & 26,75 & 27,43 & 26,98 \\
\hline $\mathrm{MnO}$ & 0,54 & 0,52 & 0,52 & 0,53 & 0,52 & 0,51 & 0,5 & 0,47 & 0,49 & 0,52 & 0,5 & 0,51 & 0,5 & 0,51 & 0,53 & 0,41 & 0,49 \\
\hline $\mathrm{MgO}$ & 18,86 & 18,96 & 18,5 & 18,39 & 18,72 & 19,11 & 17,96 & 19 & 18,74 & 19,27 & 19,09 & 18,99 & 18,56 & 18,56 & 18,85 & 18,88 & 18,71 \\
\hline $\mathrm{CaO}$ & 0,75 & 1,05 & 0,71 & 0,93 & 0,68 & 0,65 & 2,74 & 0,72 & 0,74 & 1,03 & 0,6 & 0,61 & 0,79 & 0,63 & 0,76 & 0,69 & 0,61 \\
\hline $\mathrm{Na} 2 \mathrm{O}$ & 0,01 & 0,03 & 0 & 0,03 & 0,03 & 0,01 & 0,13 & 0,03 & 0,01 & 0 & 0,01 & 0,03 & 0,02 & 0 & 0,01 & 0,02 & 0,01 \\
\hline $\mathrm{K} 2 \mathrm{O}$ & 0 & 0 & 0 & 0 & 0 & 0 & 0 & 0 & 0 & 0 & 0 & 0 & 0 & 0 & 0 & 0 & 0 \\
\hline Totals & 99,76 & 99,88 & 99,79 & 99,38 & 100,52 & 98,81 & 99,3 & 100 & 98,86 & 100,07 & 99,73 & 99,76 & 100,05 & 99,96 & 100,99 & 100,9 & 100,05 \\
\hline Oxygens & 6 & 6 & 6 & 6 & 6 & 6 & 6 & 6 & 6 & 6 & 6 & 6 & 6 & 6 & 6 & 6 & 6 \\
\hline $\mathrm{Si}$ & 1,949 & 1,964 & 1,957 & 1,981 & 1,952 & 1,985 & 1,98 & 1,963 & 1,982 & 1,968 & 1,977 & 1,982 & 1,972 & 1,967 & 1,953 & 1,972 & 1,982 \\
\hline $\mathrm{Ti}$ & 0,003 & 0,003 & 0,003 & 0,002 & 0,003 & 0,002 & 0,002 & 0,003 & 0,002 & 0,003 & 0,003 & 0,002 & 0,003 & 0,003 & 0,003 & 0,003 & 0,003 \\
\hline $\mathrm{Al}$ & 0,055 & 0,059 & 0,069 & 0,064 & 0,067 & 0,047 & 0,068 & 0,065 & 0,066 & 0,058 & 0,053 & 0,052 & 0,062 & 0,067 & 0,066 & 0,049 & 0,048 \\
\hline $\mathrm{Cr}$ & 0 & 0 & 0 & 0 & 0 & 0 & 0 & 0 & 0 & 0 & 0 & 0 & 0 & 0 & 0 & 0 & 0 \\
\hline $\mathrm{Fe} 3$ & 0,042 & 0,01 & 0,011 & 0 & 0,025 & 0 & 0 & 0,006 & 0 & 0 & 0 & 0 & 0 & 0 & 0,023 & 0,003 & 0 \\
\hline $\mathrm{Fe} 2$ & 0,827 & 0,826 & 0,86 & 0,834 & 0,847 & 0,821 & 0,78 & 0,841 & 0,818 & 0,823 & 0,838 & 0,836 & 0,855 & 0,863 & 0,845 & 0,867 & 0,858 \\
\hline $\mathrm{Mn}$ & 0,018 & 0,017 & 0,017 & 0,017 & 0,017 & 0,016 & 0,016 & 0,015 & 0,016 & 0,017 & 0,016 & 0,016 & 0,016 & 0,017 & 0,017 & 0,013 & 0,016 \\
\hline $\mathrm{Mg}$ & 1,075 & 1,076 & 1,054 & 1,046 & 1,059 & 1,091 & 1,021 & 1,077 & 1,069 & 1,089 & 1,083 & 1,076 & 1,053 & 1,055 & 1,062 & 1,064 & 1,06 \\
\hline $\mathrm{Ca}$ & 0,031 & 0,043 & 0,029 & 0,038 & 0,028 & 0,027 & 0,112 & 0,03 & 0,03 & 0,042 & 0,024 & 0,025 & 0,032 & 0,026 & 0,031 & 0,028 & 0,025 \\
\hline $\mathrm{Na}$ & 0,001 & 0,002 & 0 & 0,002 & 0,002 & 0,001 & 0,01 & 0,002 & 0,001 & 0 & 0,001 & 0,002 & 0,001 & 0 & 0,001 & 0,001 & 0,001 \\
\hline $\mathrm{K}$ & 0 & 0 & 0 & 0 & 0 & 0 & 0 & 0 & 0 & 0 & 0 & 0 & 0 & 0 & 0 & 0 & 0 \\
\hline Sum & 4 & 4 & 4 & 3,985 & 4 & 3,99 & 3,989 & 4 & 3,984 & 4 & 3,995 & 3,991 & 3,995 & 3,997 & 4 & 4 & 3,992 \\
\hline
\end{tabular}


ALFE45N - Ortopiroxênio

\begin{tabular}{|c|c|c|c|c|c|c|c|c|c|c|c|c|}
\hline Sample & 401 & 402 & 403 & 501 & 502 & 503 & 504 & 505 & 601 & 602 & 603 & 604 \\
\hline Min & opx & opx & opx & opx & opx & opx & opx & opx & opx & opx & opx & opx \\
\hline $\mathrm{SiO} 2$ & 51,81 & 51,99 & 51,98 & 52,07 & 51,7 & 51,9 & 52,08 & 52,26 & 52,17 & 52,11 & 52,03 & 52,04 \\
\hline $\mathrm{TiO} 2$ & 0,07 & 0,08 & 0,07 & 0 & 0,07 & 0,09 & 0,06 & 0,05 & 0,07 & 0,07 & 0 & 0,07 \\
\hline $\mathrm{A} 12 \mathrm{O} 3$ & 1,23 & 1,19 & 1,14 & 1,02 & 1,48 & 1,22 & 1,22 & 1,04 & 1,19 & 1,36 & 1,39 & 1,32 \\
\hline $\mathrm{Cr} 2 \mathrm{O} 3$ & 0 & 0 & 0 & 0 & 0 & 0 & 0 & 0 & 0 & 0 & 0 & 0 \\
\hline $\mathrm{Fe} 2 \mathrm{O} 3$ & 0 & 0 & 0 & 0,13 & 0,04 & 0 & 0 & 0 & 0,79 & 0 & 0 & 0,61 \\
\hline $\mathrm{FeO}$ & 28,39 & 27,26 & 27,5 & 27,57 & 27,51 & 27,82 & 27,67 & 27,84 & 27,06 & 26,19 & 27,26 & 27,63 \\
\hline $\mathrm{MnO}$ & 0,56 & 0,49 & 0,51 & 0,52 & 0,5 & 0,48 & 0,5 & 0,51 & 0,5 & 0,49 & 0,53 & 0,49 \\
\hline $\mathrm{MgO}$ & 17,81 & 18,59 & 18,56 & 18,76 & 18,2 & 18,19 & 18,32 & 18,62 & 18,98 & 18,38 & 18,49 & 18,73 \\
\hline $\mathrm{CaO}$ & 0,61 & 0,83 & 0,82 & 0,57 & 1,09 & 0,69 & 0,56 & 0,72 & 0,76 & 1,66 & 0,73 & 0,59 \\
\hline $\mathrm{Na} 2 \mathrm{O}$ & 0 & 0 & 0 & 0 & 0,01 & 0,01 & 0,01 & 0 & 0,02 & 0,05 & 0 & 0,01 \\
\hline $\mathrm{K} 2 \mathrm{O}$ & 0 & 0 & 0 & 0 & 0 & 0 & 0 & 0 & 0 & 0 & 0 & 0 \\
\hline Totals & 100,48 & 100,42 & 100,58 & 100,63 & 100,59 & 100,41 & 100,44 & 101,05 & 101,53 & 100,32 & 100,42 & 101,48 \\
\hline Oxygens & 6 & 6 & 6 & 6 & 6 & 6 & 6 & 6 & 6 & 6 & 6 & 6 \\
\hline $\mathrm{Si}$ & 1,976 & 1,974 & 1,973 & 1,975 & 1,965 & 1,975 & 1,979 & 1,976 & 1,961 & 1,976 & 1,975 & 1,96 \\
\hline $\mathrm{Ti}$ & 0,002 & 0,002 & 0,002 & 0 & 0,002 & 0,003 & 0,002 & 0,001 & 0,002 & 0,002 & 0 & 0,002 \\
\hline $\mathrm{Al}$ & 0,055 & 0,053 & 0,051 & 0,045 & 0,066 & 0,055 & 0,055 & 0,046 & 0,053 & 0,061 & 0,062 & 0,059 \\
\hline $\mathrm{Cr}$ & 0 & 0 & 0 & 0 & 0 & 0 & 0 & 0 & 0 & 0 & 0 & 0 \\
\hline $\mathrm{Fe} 3$ & 0 & 0 & 0 & 0,004 & 0,001 & 0 & 0 & 0 & 0,022 & 0 & 0 & 0,017 \\
\hline $\mathrm{Fe} 2$ & 0,906 & 0,866 & 0,873 & 0,875 & 0,874 & 0,886 & 0,879 & 0,88 & 0,851 & 0,83 & 0,865 & 0,87 \\
\hline $\mathrm{Mn}$ & 0,018 & 0,016 & 0,016 & 0,017 & 0,016 & 0,015 & 0,016 & 0,016 & 0,016 & 0,016 & 0,017 & 0,016 \\
\hline $\mathrm{Mg}$ & 1,012 & 1,052 & 1,05 & 1,061 & 1,031 & 1,032 & 1,038 & 1,049 & 1,063 & 1,038 & 1,046 & 1,051 \\
\hline $\mathrm{Ca}$ & 0,025 & 0,034 & 0,033 & 0,023 & 0,044 & 0,028 & 0,023 & 0,029 & 0,031 & 0,067 & 0,03 & 0,024 \\
\hline $\mathrm{Na}$ & 0 & 0 & 0 & 0 & 0,001 & 0,001 & 0,001 & 0 & 0,001 & 0,004 & 0 & 0 \\
\hline $\mathrm{K}$ & 0 & 0 & 0 & 0 & 0 & 0 & 0 & 0 & 0 & 0 & 0 & 0 \\
\hline Sum & 3,994 & 3,997 & 3,999 & 4 & 4 & 3,995 & 3,992 & 3,999 & 4 & 3,994 & 3,994 & 4 \\
\hline
\end{tabular}


ALFE45N - Plagioclásio

\begin{tabular}{|c|c|c|c|c|c|c|c|c|c|c|c|c|c|c|c|c|c|c|c|c|}
\hline Sample & 101 & 102 & 103 & 104 & 201 & 202 & 203 & 204 & 301 & 302 & 303 & 304 & 401 & 402 & 403 & 404 & 501 & 502 & 503 & 504 \\
\hline Min & fsp & fsp & fsp & fsp & fsp & fsp & fsp & fsp & fsp & fsp & fsp & fsp & fsp & fsp & fsp & fsp & fsp & fsp & fsp & fsp \\
\hline $\mathrm{SiO} 2$ & 61,26 & 60,52 & 61,29 & 61,31 & 60,5 & 59,37 & 60,44 & 61 & 60,3 & 60,75 & 60,87 & 59,86 & 60,54 & 60,85 & 60,8 & 60,73 & 60,98 & 60,49 & 60,41 & 61,4 \\
\hline $\mathrm{TiO} 2$ & 0 & 0 & 0 & 0 & 0 & 0 & 0 & 0 & 0 & 0 & 0 & 0 & 0 & 0 & 0 & 0 & 0 & 0 & 0 & 0 \\
\hline $\mathrm{A} 12 \mathrm{O} 3$ & 23,28 & 23,51 & 23,41 & 23,66 & 23,47 & 23,24 & 23,3 & 23,55 & 23,4 & 23,48 & 23,19 & 23,43 & 23,49 & 23,08 & 23,49 & 23,52 & 23,28 & 23,27 & 23,44 & 23,49 \\
\hline $\mathrm{Cr} 2 \mathrm{O} 3$ & 0 & 0 & 0 & 0 & 0 & 0 & 0 & 0 & 0 & 0 & 0 & 0 & 0 & 0 & 0 & 0 & 0 & 0 & 0 & 0 \\
\hline $\mathrm{Fe} 2 \mathrm{O} 3$ & 0 & 0 & 0 & 0 & 0 & 0 & 0 & 0 & 0 & 0 & 0 & 0 & 0 & 0 & 0 & 0 & 0 & 0 & 0 & 0 \\
\hline $\mathrm{FeO}$ & 0 & 0 & 0 & 0 & 0 & 0 & 0 & 0 & 0 & 0 & 0 & 0 & 0 & 0 & 0 & 0 & 0 & 0 & 0 & 0 \\
\hline $\mathrm{MnO}$ & 0 & 0 & 0 & 0 & 0 & 0 & 0 & 0 & 0 & 0 & 0 & 0 & 0 & 0 & 0 & 0 & 0 & 0 & 0 & 0 \\
\hline $\mathrm{MgO}$ & 0 & 0 & 0 & 0 & 0 & 0 & 0 & 0 & 0 & 0 & 0 & 0 & 0 & 0 & 0 & 0 & 0 & 0 & 0 & 0 \\
\hline $\mathrm{CaO}$ & 5,89 & 5,87 & 5,78 & 5,88 & 5,89 & 5,72 & 5,85 & 5,79 & 5,81 & 5,86 & 5,56 & 5,82 & 5,92 & 5,72 & 6,04 & 5,84 & 5,89 & 5,92 & 5,91 & 5,92 \\
\hline $\mathrm{Na} 2 \mathrm{O}$ & 8,03 & 8,06 & 8,2 & 8,1 & 8,23 & 8,18 & 8,07 & 8,29 & 8,12 & 8,03 & 8,2 & 8,28 & 7,97 & 8,07 & 7,93 & 8,01 & 8,11 & 8,05 & 8,04 & 7,91 \\
\hline $\mathrm{K} 2 \mathrm{O}$ & 0,36 & 0,36 & 0,32 & 0,24 & 0,21 & 0,31 & 0,32 & 0,29 & 0,35 & 0,29 & 0,34 & 0,23 & 0,47 & 0,51 & 0,48 & 0,36 & 0,29 & 0,47 & 0,43 & 0,48 \\
\hline Totals & 98,82 & 98,32 & 99 & 99,19 & 98,31 & 96,81 & 97,98 & 98,94 & 97,98 & 98,41 & 98,15 & 97,61 & 98,38 & 98,23 & 98,73 & 98,46 & 98,55 & 98,2 & 98,23 & 99,19 \\
\hline Oxygens & 8 & 8 & 8 & 8 & 8 & 8 & 8 & 8 & 8 & 8 & 8 & 8 & 8 & 8 & 8 & 8 & 8 & 8 & 8 & 8 \\
\hline $\mathrm{Si}$ & 2,752 & 2,736 & 2,749 & 2,743 & 2,735 & 2,728 & 2,741 & 2,738 & 2,735 & 2,741 & 2,753 & 2,725 & 2,735 & 2,753 & 2,738 & 2,739 & 2,749 & 2,74 & 2,735 & 2,749 \\
\hline $\mathrm{Ti}$ & 0 & 0 & 0 & 0 & 0 & 0 & 0 & 0 & 0 & 0 & 0 & 0 & 0 & 0 & 0 & 0 & 0 & 0 & 0 & 0 \\
\hline $\mathrm{Al}$ & 1,233 & 1,253 & 1,238 & 1,248 & 1,251 & 1,259 & 1,246 & 1,246 & 1,252 & 1,249 & 1,236 & 1,258 & 1,251 & 1,231 & 1,247 & 1,251 & 1,237 & 1,243 & 1,251 & 1,24 \\
\hline $\mathrm{Cr}$ & 0 & 0 & 0 & 0 & 0 & 0 & 0 & 0 & 0 & 0 & 0 & 0 & 0 & 0 & 0 & 0 & 0 & 0 & 0 & 0 \\
\hline $\mathrm{Fe} 3$ & 0,003 & 0,001 & 0 & 0,001 & 0,001 & 0 & 0 & 0,005 & 0,002 & 0,001 & 0,001 & 0,005 & 0,002 & 0,001 & 0,001 & 0,002 & 0 & 0,001 & 0,001 & 0,002 \\
\hline $\mathrm{Fe} 2$ & 0 & 0 & 0 & 0 & 0 & 0 & 0 & 0 & 0 & 0 & 0 & 0 & 0 & 0 & 0 & 0 & 0 & 0 & 0 & 0 \\
\hline $\mathrm{Mn}$ & 0 & 0 & 0 & 0 & 0 & 0 & 0 & 0 & 0 & 0 & 0 & 0 & 0 & 0 & 0 & 0 & 0 & 0 & 0 & 0 \\
\hline $\mathrm{Mg}$ & 0 & 0 & 0 & 0 & 0 & 0 & 0 & 0 & 0 & 0 & 0 & 0 & 0 & 0 & 0 & 0 & 0 & 0 & 0 & 0 \\
\hline $\mathrm{Ca}$ & 0,283 & 0,284 & 0,278 & 0,282 & 0,285 & 0,282 & 0,284 & 0,279 & 0,282 & 0,283 & 0,269 & 0,284 & 0,286 & 0,277 & 0,291 & 0,282 & 0,284 & 0,288 & 0,287 & 0,284 \\
\hline $\mathrm{Na}$ & 0,7 & 0,707 & 0,713 & 0,703 & 0,722 & 0,728 & 0,71 & 0,721 & 0,714 & 0,702 & 0,719 & 0,731 & 0,698 & 0,708 & 0,692 & 0,7 & 0,709 & 0,707 & 0,705 & 0,687 \\
\hline K & 0,021 & 0,021 & 0,018 & 0,014 & 0,012 & 0,018 & 0,019 & 0,017 & 0,021 & 0,017 & 0,019 & 0,013 & 0,027 & 0,029 & 0,028 & 0,021 & 0,017 & 0,027 & 0,025 & 0,027 \\
\hline Sum & 4,991 & 5,001 & 4,997 & 4,991 & 5,006 & 5,016 & 5 & 5,005 & 5,005 & 4,993 & 4,998 & 5,015 & 5 & 4,999 & 4,998 & 4,995 & 4,996 & 5,005 & 5,004 & 4,988 \\
\hline
\end{tabular}


ALFE45V1 -Granada

\begin{tabular}{|c|c|c|c|c|c|c|c|c|c|c|c|c|c|c|c|c|c|c|c|c|}
\hline Sample & 101 & 102 & 103 & 104 & 105 & 106 & 107 & 108 & 201 & 202 & 203 & 204 & 205 & 206 & 207 & 301 & 302 & 303 & 304 & 305 \\
\hline Min & $\mathrm{g}$ & $\mathrm{g}$ & $\mathrm{g}$ & $\mathrm{g}$ & $\mathrm{g}$ & $\mathrm{g}$ & $\mathrm{g}$ & $\mathrm{g}$ & $\mathrm{g}$ & $\mathrm{g}$ & $\mathrm{g}$ & $\mathrm{g}$ & $\mathrm{g}$ & $\mathrm{g}$ & $\mathrm{g}$ & $\mathrm{g}$ & $\mathrm{g}$ & $\mathrm{g}$ & $\mathrm{g}$ & $\mathrm{g}$ \\
\hline $\mathrm{SiO} 2$ & 39,87 & 40,12 & 40,46 & 40,01 & 40,34 & 39,98 & 40,09 & 39,97 & 39,67 & 40,25 & 39,91 & 40,09 & 39,66 & 40,11 & 38,99 & 39,74 & 39,72 & 39,56 & 40,2 & 39,94 \\
\hline $\mathrm{TiO} 2$ & 0,03 & 0,04 & 0,03 & 0,04 & 0,02 & 0,01 & 0,02 & 0,04 & 0,02 & 0,04 & 0,02 & 0,05 & 0,03 & 0,03 & 0,04 & 0,05 & 0,04 & 0,04 & 0,04 & 0,02 \\
\hline $\mathrm{A} 12 \mathrm{O} 3$ & 20,47 & 20,63 & 20,49 & 20,63 & 20,8 & 20 & 20,66 & 20,41 & 20,46 & 20,42 & 20,42 & 20,57 & 20,4 & 20,59 & 19,72 & 20,37 & 20,36 & 20,53 & 20,37 & 19,93 \\
\hline $\mathrm{Cr} 2 \mathrm{O} 3$ & 0 & 0 & 0 & 0 & 0 & 0 & 0 & 0 & 0 & 0 & 0 & 0 & 0 & 0 & 0 & 0 & 0 & 0 & 0 & 0 \\
\hline $\mathrm{Fe} 2 \mathrm{O} 3$ & 0 & 0 & 0 & 0 & 0 & 0 & 0 & 0 & 0 & 0 & 0 & 0 & 0 & 0 & 0 & 0 & 0 & 0 & 0 & 0 \\
\hline $\mathrm{FeO}$ & 23,97 & 23,19 & 22 & 23,03 & 23,23 & 23,59 & 23,65 & 22,64 & 24,16 & 22,66 & 22,49 & 23,18 & 23,01 & 23,14 & 24,14 & 23,92 & 24 & 23,49 & 23,76 & 23,94 \\
\hline $\mathrm{MnO}$ & 2,38 & 2,29 & 2,23 & 2,27 & 2,28 & 2,26 & 2,27 & 2,49 & 2,41 & 2,15 & 2,26 & 2,29 & 2,33 & 2,36 & 2,3 & 2,2 & 2,22 & 2,21 & 2,17 & 2,5 \\
\hline $\mathrm{MgO}$ & 6,15 & 6,6 & 6,67 & 6,77 & 6,51 & 6,8 & 6,65 & 6,48 & 5,77 & 6,59 & 6,33 & 6,65 & 6,64 & 6,75 & 6,15 & 6,16 & 6,37 & 6,49 & 6,18 & 5,57 \\
\hline $\mathrm{CaO}$ & 6,26 & 6,37 & 6,57 & 6,43 & 6,48 & 6,03 & 6,05 & 6,19 & 6,33 & 6,87 & 6,45 & 6,07 & 6,46 & 6,26 & 6,06 & 6,53 & 6,47 & 6,53 & 6,56 & 6,55 \\
\hline $\mathrm{Na} 2 \mathrm{O}$ & 0 & 0 & 0 & 0 & 0 & 0 & 0 & 0 & 0 & 0 & 0 & 0 & 0 & 0 & 0 & 0 & 0 & 0 & 0 & 0 \\
\hline $\mathrm{K} 2 \mathrm{O}$ & 0 & 0 & 0 & 0 & 0 & 0 & 0 & 0 & 0 & 0 & 0 & 0 & 0 & 0 & 0 & 0 & 0 & 0 & 0 & 0 \\
\hline Totals & 99,13 & 99,25 & 98,44 & 99,19 & 99,65 & 98,67 & 99,4 & 98,22 & 98,83 & 98,98 & 97,89 & 98,89 & 98,52 & 99,24 & 97,41 & 98,98 & 99,19 & 98,85 & 99,28 & 98,46 \\
\hline Oxygens & 12 & 12 & 12 & 12 & 12 & 12 & 12 & 12 & 12 & 12 & 12 & 12 & 12 & 12 & 12 & 12 & 12 & 12 & 12 & 12 \\
\hline $\mathrm{Si}$ & 3,108 & 3,111 & 3,143 & 3,103 & 3,113 & 3,124 & 3,107 & 3,126 & 3,107 & 3,124 & 3,13 & 3,117 & 3,101 & 3,109 & 3,104 & 3,104 & 3,097 & 3,089 & 3,124 & 3,14 \\
\hline $\mathrm{Ti}$ & 0,001 & 0,002 & 0,002 & 0,003 & 0,001 & 0,001 & 0,001 & 0,002 & 0,001 & 0,003 & 0,001 & 0,003 & 0,002 & 0,002 & 0,003 & 0,003 & 0,003 & 0,003 & 0,002 & 0,001 \\
\hline $\mathrm{Al}$ & 1,882 & 1,886 & 1,877 & 1,886 & 1,892 & 1,842 & 1,888 & 1,882 & 1,89 & 1,868 & 1,887 & 1,885 & 1,881 & 1,882 & 1,851 & 1,876 & 1,872 & 1,89 & 1,866 & 1,847 \\
\hline $\mathrm{Cr}$ & 0 & 0 & 0 & 0 & 0 & 0 & 0 & 0 & 0 & 0 & 0 & 0 & 0 & 0 & 0 & 0 & 0 & 0 & 0 & 0 \\
\hline $\mathrm{Fe} 3$ & 0 & 0 & 0 & 0 & 0 & 0 & 0 & 0 & 0 & 0 & 0 & 0 & 0 & 0 & 0 & 0 & 0 & 0 & 0 & 0 \\
\hline $\mathrm{Fe} 2$ & 1,563 & 1,503 & 1,429 & 1,494 & 1,499 & 1,541 & 1,532 & 1,481 & 1,583 & 1,47 & 1,475 & 1,507 & 1,505 & 1,5 & 1,608 & 1,563 & 1,565 & 1,534 & 1,544 & 1,574 \\
\hline $\mathrm{Mn}$ & 0,157 & 0,151 & 0,147 & 0,149 & 0,149 & 0,15 & 0,149 & 0,165 & 0,16 & 0,141 & 0,15 & 0,151 & 0,154 & 0,155 & 0,155 & 0,146 & 0,147 & 0,146 & 0,143 & 0,166 \\
\hline $\mathrm{Mg}$ & 0,715 & 0,762 & 0,772 & 0,782 & 0,749 & 0,792 & 0,768 & 0,755 & 0,674 & 0,762 & 0,739 & 0,77 & 0,773 & 0,78 & 0,729 & 0,717 & 0,74 & 0,755 & 0,716 & 0,652 \\
\hline $\mathrm{Ca}$ & 0,523 & 0,529 & 0,547 & 0,535 & 0,536 & 0,505 & 0,503 & 0,519 & 0,531 & 0,571 & 0,542 & 0,506 & 0,541 & 0,52 & 0,517 & 0,546 & 0,541 & 0,546 & 0,546 & 0,552 \\
\hline $\mathrm{Na}$ & 0 & 0 & 0 & 0 & 0 & 0 & 0 & 0 & 0 & 0 & 0 & 0 & 0 & 0 & 0 & 0 & 0 & 0 & 0 & 0 \\
\hline $\mathrm{K}$ & 0 & 0 & 0 & 0 & 0 & 0 & 0 & 0 & 0 & 0 & 0 & 0 & 0 & 0 & 0 & 0 & 0 & 0 & 0 & 0 \\
\hline Sum & 7,95 & 7,944 & 7,917 & 7,952 & 7,94 & 7,955 & 7,948 & 7,931 & 7,947 & 7,94 & 7,925 & 7,938 & 7,957 & 7,948 & 7,968 & 7,955 & 7,965 & 7,964 & 7,941 & 7,935 \\
\hline
\end{tabular}


ALFE45V1 - Ortopiroxênio

\begin{tabular}{|c|c|c|c|c|c|c|c|c|c|c|c|c|c|c|c|c|c|c|}
\hline Sample & 101 & 102 & 103 & 104 & 105 & 106 & 107 & 201 & 202 & 203 & 204 & 205 & 206 & 207 & 208 & 209 & 210 & 211 \\
\hline Min & opx & opx & opx & opx & opx & opx & opx & opx & opx & opx & opx & opx & opx & opx & opx & opx & opx & opx \\
\hline $\mathrm{SiO} 2$ & 50,75 & 50,35 & 50,24 & 50,6 & 50,59 & 51,18 & 50,92 & 50,99 & 50,58 & 50,76 & 50,22 & 50,45 & 50,64 & 49,6 & 50,34 & 50,38 & 50,84 & 50,98 \\
\hline $\mathrm{TiO} 2$ & 0,09 & 0,11 & 0,11 & 0,09 & 0,1 & 0,08 & 0,08 & 0,1 & 0,1 & 0,1 & 0,07 & 0,09 & 0,09 & 0,04 & 0,11 & 0,09 & 0,1 & 0,09 \\
\hline $\mathrm{Al} 2 \mathrm{O} 3$ & 1,43 & 1,58 & 1,75 & 1,71 & 1,75 & 1,27 & 1,31 & 1,6 & 1,67 & 1,73 & 1,78 & 1,77 & 1,71 & 1,75 & 1,77 & 1,81 & 1,54 & 1,3 \\
\hline $\mathrm{Cr} 2 \mathrm{O} 3$ & 0 & 0 & 0 & 0 & 0 & 0 & 0 & 0 & 0 & 0 & 0 & 0 & 0 & 0 & 0 & 0 & 0 & 0 \\
\hline $\mathrm{Fe} 2 \mathrm{O} 3$ & 1,01 & 0,83 & 1,8 & 0,77 & 1,58 & 0,33 & 0,35 & 0 & 0 & 0,07 & 0 & 0 & 0 & 0 & 0,01 & 0 & 0 & 0 \\
\hline $\mathrm{FeO}$ & 25,43 & 26,04 & 25,16 & 26,53 & 25,53 & 26,46 & 26,61 & 26,53 & 25,63 & 27,42 & 27,17 & 27,25 & 27,36 & 26,48 & 27,01 & 26,08 & 26,57 & 26,36 \\
\hline $\mathrm{MnO}$ & 1,48 & 1,52 & 1,43 & 1,44 & 1,51 & 1,52 & 1,53 & 1,08 & 0,91 & 0,88 & 0,97 & 0,9 & 0,83 & 0,84 & 0,77 & 0,77 & 0,8 & 0,86 \\
\hline $\mathrm{MgO}$ & 18,02 & 17,57 & 17,63 & 17,68 & 17,63 & 17,7 & 17,79 & 17,12 & 17,14 & 17,56 & 17,13 & 16,79 & 17,15 & 17,18 & 17,48 & 16,7 & 18,01 & 18,03 \\
\hline $\mathrm{CaO}$ & 1,2 & 0,99 & 1,42 & 0,73 & 1,36 & 1,24 & 0,79 & 0,87 & 1,11 & 0,8 & 0,91 & 1,24 & 0,89 & 0,83 & 0,93 & 1,72 & 0,82 & 0,88 \\
\hline $\mathrm{Na} 2 \mathrm{O}$ & 0,04 & 0,03 & 0,07 & 0,03 & 0,08 & 0,03 & 0,02 & 0,01 & 0,03 & 0,03 & 0,03 & 0,06 & 0,03 & 0,03 & 0,04 & 0,09 & 0,02 & 0,03 \\
\hline $\mathrm{K} 2 \mathrm{O}$ & 0 & 0 & 0 & 0 & 0 & 0 & 0 & 0 & 0 & 0 & 0 & 0 & 0 & 0 & 0 & 0 & 0 & 0 \\
\hline Totals & 99,45 & 99,02 & 99,61 & 99,6 & 100,13 & 99,8 & 99,39 & 98,32 & 97,16 & 99,36 & 98,27 & 98,55 & 98,71 & 96,76 & 98,47 & 97,63 & 98,7 & 98,53 \\
\hline Oxygens & 6 & 6 & 6 & 6 & 6 & 6 & 6 & 6 & 6 & 6 & 6 & 6 & 6 & 6 & 6 & 6 & 6 & 6 \\
\hline $\mathrm{Si}$ & 1,952 & 1,95 & 1,934 & 1,948 & 1,938 & 1,965 & 1,964 & 1,98 & 1,981 & 1,958 & 1,959 & 1,964 & 1,966 & 1,961 & 1,957 & 1,971 & 1,965 & 1,973 \\
\hline $\mathrm{Ti}$ & 0,003 & 0,003 & 0,003 & 0,003 & 0,003 & 0,002 & 0,002 & 0,003 & 0,003 & 0,003 & 0,002 & 0,003 & 0,003 & 0,001 & 0,003 & 0,003 & 0,003 & 0,003 \\
\hline Al & 0,065 & 0,072 & 0,08 & 0,078 & 0,079 & 0,057 & 0,059 & 0,073 & 0,077 & 0,078 & 0,082 & 0,081 & 0,078 & 0,082 & 0,081 & 0,084 & 0,07 & 0,059 \\
\hline $\mathrm{Cr}$ & 0 & 0 & 0 & 0 & 0 & 0 & 0 & 0 & 0 & 0 & 0 & 0 & 0 & 0 & 0 & 0 & 0 & 0 \\
\hline $\mathrm{Fe} 3$ & 0,029 & 0,024 & 0,052 & 0,022 & 0,045 & 0,01 & 0,01 & 0 & 0 & 0,002 & 0 & 0 & 0 & 0 & 0 & 0 & 0 & 0 \\
\hline $\mathrm{Fe} 2$ & 0,818 & 0,843 & 0,81 & 0,854 & 0,818 & 0,85 & 0,858 & 0,861 & 0,839 & 0,885 & 0,887 & 0,887 & 0,888 & 0,876 & 0,878 & 0,853 & 0,859 & 0,853 \\
\hline $\mathrm{Mn}$ & 0,048 & 0,05 & 0,046 & 0,047 & 0,049 & 0,049 & 0,05 & 0,036 & 0,03 & 0,029 & 0,032 & 0,03 & 0,027 & 0,028 & 0,025 & 0,026 & 0,026 & 0,028 \\
\hline $\mathrm{Mg}$ & 1,033 & 1,014 & 1,011 & 1,015 & 1,007 & 1,013 & 1,022 & 0,991 & 1 & 1,009 & 0,996 & 0,974 & 0,992 & 1,012 & 1,013 & 0,973 & 1,038 & 1,04 \\
\hline $\mathrm{Ca}$ & 0,049 & 0,041 & 0,059 & 0,03 & 0,056 & 0,051 & 0,033 & 0,036 & 0,047 & 0,033 & 0,038 & 0,052 & 0,037 & 0,035 & 0,039 & 0,072 & 0,034 & 0,036 \\
\hline $\mathrm{Na}$ & 0,003 & 0,002 & 0,005 & 0,002 & 0,006 & 0,002 & 0,001 & 0,001 & 0,003 & 0,003 & 0,003 & 0,005 & 0,002 & 0,002 & 0,003 & 0,007 & 0,002 & 0,002 \\
\hline K & 0 & 0 & 0 & 0 & 0 & 0 & 0 & 0 & 0 & 0 & 0 & 0 & 0 & 0 & 0 & 0 & 0 & 0 \\
\hline Sum & 4 & 4 & 4 & 4 & 4 & 4 & 4 & 3,981 & 3,979 & 4 & 3,999 & 3,995 & 3,994 & 3,998 & 4 & 3,988 & 3,997 & 3,995 \\
\hline
\end{tabular}


ALFE45V1 - Ortopiroxênio

\begin{tabular}{|c|c|c|c|c|c|c|c|c|c|c|c|c|c|c|c|c|c|}
\hline Sample & 301 & 302 & 303 & 304 & 305 & 401 & 403 & 404 & 405 & 406 & 501 & 502 & 503 & 504 & 505 & 506 & 507 \\
\hline Min & opx & opx & opx & opx & opx & opx & opx & opx & opx & opx & opx & opx & opx & opx & opx & opx & opx \\
\hline $\mathrm{SiO} 2$ & 50,51 & 50,49 & 49,92 & 50,59 & 51,35 & 51,53 & 51,33 & 51,57 & 51,35 & 51,12 & 51,3 & 51,45 & 51,22 & 51,48 & 52 & 51,31 & 50,21 \\
\hline $\mathrm{TiO} 2$ & 0,08 & 0,09 & 0,11 & 0,1 & 0,07 & 0,05 & 0,05 & 0,04 & 0,07 & 0,05 & 0,01 & 0,04 & 0,04 & 0,05 & 0,06 & 0,09 & 0,12 \\
\hline $\mathrm{Al} 2 \mathrm{O} 3$ & 1,74 & 1,53 & 1,71 & 1,86 & 1,51 & 1,48 & 1,39 & 1,41 & 1,59 & 1,63 & 1,41 & 1,44 & 1,61 & 1,35 & 1,16 & 1,51 & 1,17 \\
\hline $\mathrm{Cr} 2 \mathrm{O} 3$ & 0 & 0 & 0 & 0 & 0 & 0 & 0 & 0 & 0 & 0 & 0 & 0 & 0 & 0 & 0 & 0 & 0 \\
\hline $\mathrm{Fe} 2 \mathrm{O} 3$ & 0 & 0 & 0 & 0 & 0,02 & 0 & 0 & 0 & 0 & 0 & 0 & 0 & 0 & 0,41 & 0 & 0 & 0 \\
\hline $\mathrm{FeO}$ & 27,01 & 27,22 & 26,28 & 27,21 & 27,18 & 26,3 & 26,89 & 27,33 & 26,78 & 26,25 & 26,04 & 26,12 & 27,12 & 26,45 & 26,51 & 26,32 & 25,86 \\
\hline $\mathrm{MnO}$ & 0,73 & 0,76 & 0,71 & 0,75 & 0,82 & 0,97 & 0,82 & 0,93 & 0,89 & 0,96 & 0,72 & 0,73 & 0,7 & 0,67 & 0,63 & 0,73 & 0,71 \\
\hline $\mathrm{MgO}$ & 17,35 & 17,29 & 17,19 & 17,21 & 17,87 & 17,93 & 18,11 & 18,06 & 17,84 & 17,78 & 17,75 & 18,14 & 17,96 & 18,92 & 18,68 & 18,32 & 18,03 \\
\hline $\mathrm{CaO}$ & 1,06 & 0,75 & 1,31 & 1,32 & 1,2 & 0,52 & 0,55 & 0,58 & 0,69 & 0,6 & 0,62 & 0,7 & 0,66 & 0,49 & 0,45 & 0,44 & 0,51 \\
\hline $\mathrm{Na} 2 \mathrm{O}$ & 0,06 & 0,03 & 0,05 & 0,04 & 0,01 & 0,01 & 0 & 0,03 & 0,02 & 0,01 & 0,01 & 0,03 & 0,01 & 0,03 & 0,02 & 0,01 & 0 \\
\hline $\mathrm{K} 2 \mathrm{O}$ & 0 & 0 & 0 & 0 & 0 & 0 & 0 & 0 & 0 & 0 & 0 & 0 & 0 & 0 & 0 & 0 & 0 \\
\hline Totals & 98,53 & 98,17 & 97,27 & 99,06 & 100,03 & 98,79 & 99,15 & 99,95 & 99,23 & 98,41 & 97,85 & 98,64 & 99,31 & 99,86 & 99,52 & 98,74 & 96,62 \\
\hline Oxygens & 6 & 6 & 6 & 6 & 6 & 6 & 6 & 6 & 6 & 6 & 6 & 6 & 6 & 6 & 6 & 6 & 6 \\
\hline $\mathrm{Si}$ & 1,962 & 1,969 & 1,962 & 1,957 & 1,965 & 1,984 & 1,975 & 1,972 & 1,974 & 1,977 & 1,991 & 1,982 & 1,969 & 1,963 & 1,985 & 1,975 & 1,978 \\
\hline $\mathrm{Ti}$ & 0,002 & 0,003 & 0,003 & 0,003 & 0,002 & 0,001 & 0,002 & 0,001 & 0,002 & 0,001 & 0 & 0,001 & 0,001 & 0,002 & 0,002 & 0,002 & 0,004 \\
\hline $\mathrm{Al}$ & 0,08 & 0,07 & 0,079 & 0,085 & 0,068 & 0,067 & 0,063 & 0,064 & 0,072 & 0,075 & 0,065 & 0,065 & 0,073 & 0,061 & 0,052 & 0,069 & 0,054 \\
\hline $\mathrm{Cr}$ & 0 & 0 & 0 & 0 & 0 & 0 & 0 & 0 & 0 & 0 & 0 & 0 & 0 & 0 & 0 & 0 & 0 \\
\hline $\mathrm{Fe} 3$ & 0 & 0 & 0 & 0 & 0 & 0 & 0 & 0 & 0 & 0 & 0 & 0 & 0 & 0,012 & 0 & 0 & 0 \\
\hline $\mathrm{Fe} 2$ & 0,878 & 0,888 & 0,864 & 0,88 & 0,87 & 0,847 & 0,865 & 0,874 & 0,861 & 0,849 & 0,845 & 0,841 & 0,872 & 0,844 & 0,846 & 0,848 & 0,852 \\
\hline $\mathrm{Mn}$ & 0,024 & 0,025 & 0,024 & 0,025 & 0,027 & 0,032 & 0,027 & 0,03 & 0,029 & 0,032 & 0,024 & 0,024 & 0,023 & 0,022 & 0,02 & 0,024 & 0,024 \\
\hline $\mathrm{Mg}$ & 1,004 & 1,005 & 1,007 & 0,992 & 1,019 & 1,029 & 1,038 & 1,029 & 1,022 & 1,025 & 1,027 & 1,041 & 1,029 & 1,075 & 1,063 & 1,051 & 1,058 \\
\hline $\mathrm{Ca}$ & 0,044 & 0,031 & 0,055 & 0,055 & 0,049 & 0,021 & 0,023 & 0,024 & 0,028 & 0,025 & 0,026 & 0,029 & 0,027 & 0,02 & 0,018 & 0,018 & 0,022 \\
\hline $\mathrm{Na}$ & 0,005 & 0,002 & 0,004 & 0,003 & 0,001 & 0,001 & 0 & 0,002 & 0,001 & 0,001 & 0 & 0,002 & 0,001 & 0,002 & 0,001 & 0,001 & 0 \\
\hline $\mathrm{K}$ & 0 & 0 & 0 & 0 & 0 & 0 & 0 & 0 & 0 & 0 & 0 & 0 & 0 & 0 & 0 & 0 & 0 \\
\hline Sum & 3,998 & 3,994 & 3,997 & 3,999 & 4 & 3,982 & 3,992 & 3,996 & 3,989 & 3,984 & 3,977 & 3,985 & 3,994 & 4 & 3,988 & 3,988 & 3,991 \\
\hline
\end{tabular}


ALFE45V1 - Plagioclásio

\begin{tabular}{|c|c|c|c|c|c|c|c|c|c|c|c|c|c|}
\hline Sample & 101 & 102 & 103 & 104 & 201 & 202 & 203 & 204 & 205 & 301 & 302 & 303 & 304 \\
\hline Min & fsp & fsp & fsp & fsp & fsp & fsp & fsp & fsp & fsp & fsp & fsp & fsp & fsp \\
\hline $\mathrm{SiO} 2$ & 60,15 & 59,68 & 60,17 & 59,33 & 59,92 & 59,6 & 60,47 & 59,9 & 59,03 & 60,39 & 60,68 & 60,97 & 59,36 \\
\hline $\mathrm{TiO} 2$ & 0 & 0 & 0 & 0 & 0 & 0 & 0 & 0 & 0 & 0 & 0 & 0 & 0 \\
\hline $\mathrm{Al} 2 \mathrm{O} 3$ & 23,24 & 23,46 & 23,47 & 23,98 & 23,9 & 23,59 & 23,25 & 23,66 & 24,1 & 23,95 & 23,95 & 23,89 & 23,81 \\
\hline $\mathrm{Cr} 2 \mathrm{O} 3$ & 0 & 0 & 0 & 0 & 0 & 0 & 0 & 0 & 0 & 0 & 0 & 0 & 0 \\
\hline $\mathrm{Fe} 2 \mathrm{O} 3$ & 0 & 0 & 0 & 0 & 0 & 0 & 0 & 0 & 0 & 0 & 0 & 0 & 0 \\
\hline $\mathrm{FeO}$ & 0 & 0 & 0 & 0 & 0 & 0 & 0 & 0 & 0 & 0 & 0 & 0 & 0 \\
\hline $\mathrm{MnO}$ & 0 & 0 & 0 & 0 & 0 & 0 & 0 & 0 & 0 & 0 & 0 & 0 & 0 \\
\hline $\mathrm{MgO}$ & 0 & 0 & 0 & 0 & 0 & 0 & 0 & 0 & 0 & 0 & 0 & 0 & 0 \\
\hline $\mathrm{CaO}$ & 0 & 0 & 0 & 0 & 0 & 0 & 0 & 0 & 0 & 0 & 0 & 0 & 0 \\
\hline $\mathrm{Na} 2 \mathrm{O}$ & 7,77 & 8,3 & 8,35 & 7,93 & 7,9 & 8,02 & 7,88 & 7,95 & 7,78 & 7,65 & 7,73 & 7,63 & 7,55 \\
\hline $\mathrm{K} 2 \mathrm{O}$ & 0,21 & 0,26 & 0,25 & 0,2 & 0,19 & 0,37 & 0,42 & 0,38 & 0,2 & 0,35 & 0,6 & 0,63 & 0,57 \\
\hline Totals & 91,37 & 91,7 & 92,24 & 91,44 & 91,91 & 91,59 & 92,02 & 91,89 & 91,11 & 92,34 & 92,96 & 93,11 & 91,28 \\
\hline Oxygens & 8 & 8 & 8 & 8 & 8 & 8 & 8 & 8 & 8 & 8 & 8 & 8 & 8 \\
\hline $\mathrm{Si}$ & 2,839 & 2,82 & 2,828 & 2,808 & 2,822 & 2,821 & 2,844 & 2,823 & 2,802 & 2,825 & 2,828 & 2,836 & 2,816 \\
\hline $\mathrm{Ti}$ & 0 & 0 & 0 & 0 & 0 & 0 & 0 & 0 & 0 & 0 & 0 & 0 & 0 \\
\hline $\mathrm{Al}$ & 1,293 & 1,307 & 1,301 & 1,338 & 1,327 & 1,316 & 1,289 & 1,314 & 1,349 & 1,32 & 1,316 & 1,31 & 1,331 \\
\hline $\mathrm{Cr}$ & 0 & 0 & 0 & 0 & 0 & 0 & 0 & 0 & 0 & 0 & 0 & 0 & 0 \\
\hline $\mathrm{Fe} 3$ & 0,013 & 0,007 & 0,003 & 0,005 & 0 & 0,003 & 0,004 & 0,004 & 0,006 & 0,008 & 0,001 & 0,001 & 0,004 \\
\hline $\mathrm{Fe} 2$ & 0 & 0 & 0 & 0 & 0 & 0 & 0 & 0 & 0 & 0 & 0 & 0 & 0 \\
\hline $\mathrm{Mn}$ & 0 & 0 & 0 & 0 & 0 & 0 & 0 & 0 & 0 & 0 & 0 & 0 & 0 \\
\hline $\mathrm{Mg}$ & 0 & 0 & 0 & 0 & 0 & 0 & 0 & 0 & 0 & 0 & 0 & 0 & 0 \\
\hline $\mathrm{Ca}$ & 0 & 0 & 0 & 0 & 0 & 0 & 0 & 0 & 0 & 0 & 0 & 0 & 0 \\
\hline $\mathrm{Na}$ & 0,711 & 0,76 & 0,761 & 0,728 & 0,721 & 0,736 & 0,719 & 0,726 & 0,716 & 0,693 & 0,699 & 0,688 & 0,695 \\
\hline $\mathrm{K}$ & 0,013 & 0,015 & 0,015 & 0,012 & 0,012 & 0,023 & 0,025 & 0,023 & 0,012 & 0,021 & 0,036 & 0,037 & 0,034 \\
\hline Sum & 4,868 & 4,91 & 4,908 & 4,89 & 4,881 & 4,899 & 4,881 & 4,891 & 4,884 & 4,867 & 4,88 & 4,872 & 4,88 \\
\hline
\end{tabular}


ALFE45V1 - Plagioclásio

\begin{tabular}{|c|c|c|c|c|c|c|c|c|c|c|c|c|c|c|c|c|c|}
\hline Sample & 401 & 402 & 403 & 404 & 405 & 501 & 502 & 503 & 504 & 601 & 602 & 603 & 604 & 605 & 701 & 702 & 703 \\
\hline Min & fsp & fsp & fsp & fsp & fsp & fsp & fsp & fsp & fsp & fsp & fsp & fsp & fsp & fsp & fsp & fsp & fsp \\
\hline $\mathrm{SiO} 2$ & 59,02 & 59,69 & 58,93 & 58,83 & 58,71 & 58,81 & 58,53 & 59,06 & 58,36 & 57,85 & 58,81 & 59,52 & 58,82 & 58,6 & 59,58 & 60,78 & 60,44 \\
\hline $\mathrm{TiO} 2$ & 0 & 0 & 0 & 0 & 0 & 0 & 0 & 0 & 0 & 0 & 0 & 0 & 0 & 0 & 0 & 0 & 0 \\
\hline $\mathrm{A} 12 \mathrm{O} 3$ & 23,44 & 23,53 & 23,55 & 23,44 & 24,04 & 23,49 & 23,41 & 23,16 & 23,78 & 23,87 & 23,71 & 23,77 & 23,7 & 24,02 & 23,5 & 23,4 & 23,7 \\
\hline $\mathrm{Cr} 2 \mathrm{O} 3$ & 0 & 0 & 0 & 0 & 0 & 0 & 0 & 0 & 0 & 0 & 0 & 0 & 0 & 0 & 0 & 0 & 0 \\
\hline $\mathrm{Fe} 2 \mathrm{O} 3$ & 0 & 0 & 0 & 0 & 0 & 0 & 0 & 0 & 0 & 0 & 0 & 0 & 0 & 0 & 0 & 0 & 0 \\
\hline $\mathrm{FeO}$ & 0 & 0 & 0 & 0 & 0 & 0 & 0 & 0 & 0 & 0 & 0 & 0 & 0 & 0 & 0 & 0 & 0 \\
\hline $\mathrm{MnO}$ & 0 & 0 & 0 & 0 & 0 & 0 & 0 & 0 & 0 & 0 & 0 & 0 & 0 & 0 & 0 & 0 & 0 \\
\hline $\mathrm{MgO}$ & 0 & 0 & 0 & 0 & 0 & 0 & 0 & 0 & 0 & 0 & 0 & 0 & 0 & 0 & 0 & 0 & 0 \\
\hline $\mathrm{CaO}$ & 0 & 0 & 0 & 0 & 0 & 0 & 0 & 0 & 0 & 0 & 0 & 0 & 0 & 0 & 0 & 0 & 0 \\
\hline $\mathrm{Na} 2 \mathrm{O}$ & 7,57 & 7,82 & 7,8 & 7,64 & 7,6 & 7,65 & 7,71 & 7,78 & 7,67 & 7,57 & 7,65 & 7,61 & 7,59 & 7,48 & 7,5 & 7,63 & 7,4 \\
\hline $\mathrm{K} 2 \mathrm{O}$ & 0,49 & 0,55 & 0,58 & 0,49 & 0,45 & 0,53 & 0,83 & 0,6 & 0,28 & 0,3 & 0,29 & 0,37 & 0,34 & 0,28 & 0,8 & 0,82 & 0,71 \\
\hline Totals & 90,52 & 91,59 & 90,86 & 90,4 & 90,79 & 90,48 & 90,48 & 90,6 & 90,09 & 89,59 & 90,46 & 91,27 & 90,45 & 90,38 & 91,38 & 92,63 & 92,26 \\
\hline Oxygens & 8 & 8 & 8 & 8 & 8 & 8 & 8 & 8 & 8 & 8 & 8 & 8 & 8 & 8 & 8 & 8 & 8 \\
\hline $\mathrm{Si}$ & 2,824 & 2,827 & 2,814 & 2,82 & 2,801 & 2,818 & 2,813 & 2,828 & 2,803 & 2,796 & 2,815 & 2,822 & 2,815 & 2,804 & 2,828 & 2,845 & 2,836 \\
\hline $\mathrm{Ti}$ & 0 & 0 & 0 & 0 & 0 & 0 & 0 & 0 & 0 & 0 & 0 & 0 & 0 & 0 & 0 & 0 & 0 \\
\hline $\mathrm{Al}$ & 1,322 & 1,314 & 1,326 & 1,325 & 1,352 & 1,327 & 1,327 & 1,308 & 1,346 & 1,36 & 1,338 & 1,329 & 1,337 & 1,355 & 1,315 & 1,291 & 1,311 \\
\hline $\mathrm{Cr}$ & 0 & 0 & 0 & 0 & 0 & 0 & 0 & 0 & 0 & 0 & 0 & 0 & 0 & 0 & 0 & 0 & 0 \\
\hline $\mathrm{Fe} 3$ & 0,002 & 0 & 0,002 & 0,001 & 0,003 & 0,001 & 0 & 0,002 & 0,005 & 0,003 & 0 & 0,001 & 0,002 & 0,002 & 0,002 & 0,001 & 0,002 \\
\hline $\mathrm{Fe} 2$ & 0 & 0 & 0 & 0 & 0 & 0 & 0 & 0 & 0 & 0 & 0 & 0 & 0 & 0 & 0 & 0 & 0 \\
\hline $\mathrm{Mn}$ & 0 & 0 & 0 & 0 & 0 & 0 & 0 & 0 & 0 & 0 & 0 & 0 & 0 & 0 & 0 & 0 & 0 \\
\hline $\mathrm{Mg}$ & 0 & 0 & 0 & 0 & 0 & 0 & 0 & 0 & 0 & 0 & 0 & 0 & 0 & 0 & 0 & 0 & 0 \\
\hline $\mathrm{Ca}$ & 0 & 0 & 0 & 0 & 0 & 0 & 0 & 0 & 0 & 0 & 0 & 0 & 0 & 0 & 0 & 0 & 0 \\
\hline $\mathrm{Na}$ & 0,702 & 0,718 & 0,722 & 0,71 & 0,703 & 0,711 & 0,719 & 0,722 & 0,714 & 0,71 & 0,71 & 0,699 & 0,704 & 0,694 & 0,691 & 0,693 & 0,673 \\
\hline $\mathrm{K}$ & 0,03 & 0,033 & 0,035 & 0,03 & 0,027 & 0,032 & 0,051 & 0,037 & 0,017 & 0,018 & 0,018 & 0,022 & 0,021 & 0,017 & 0,048 & 0,049 & 0,043 \\
\hline Sum & 4,88 & 4,892 & 4,9 & 4,886 & 4,886 & 4,889 & 4,909 & 4,896 & 4,886 & 4,886 & 4,88 & 4,874 & 4,878 & 4,872 & 4,883 & 4,879 & 4,865 \\
\hline
\end{tabular}


ALFE45Va - Granada

\begin{tabular}{|c|c|c|c|c|c|c|c|c|c|c|c|c|c|c|c|c|c|c|c|c|c|}
\hline Sample & 101 & 102 & 103 & 104 & 105 & 106 & 107 & 108 & 109 & 110 & 111 & 112 & 113 & 114 & 115 & 116 & 117 & 118 & 119 & 120 & 121 \\
\hline Min & $\mathrm{g}$ & $\mathrm{g}$ & $\mathrm{g}$ & $\mathrm{g}$ & $\mathrm{g}$ & $\mathrm{g}$ & $\mathrm{g}$ & $\mathrm{g}$ & $\mathrm{g}$ & $\mathrm{g}$ & $\mathrm{g}$ & $\mathrm{g}$ & $\mathrm{g}$ & $\mathrm{g}$ & $\mathrm{g}$ & $\mathrm{g}$ & $\mathrm{g}$ & $\mathrm{g}$ & $\mathrm{g}$ & $\mathrm{g}$ & $\mathrm{g}$ \\
\hline $\mathrm{SiO} 2$ & 40,39 & 40,77 & 40,27 & 40,41 & 40,6 & 40,58 & 40,6 & 40,93 & 40,29 & 40,11 & 40,52 & 40,3 & 40,38 & 40,41 & 40,02 & 40,55 & 40,77 & 40,66 & 38,97 & 40,46 & 40,52 \\
\hline $\mathrm{TiO} 2$ & 0,04 & 0,03 & 0,04 & 0,04 & 0,05 & 0,05 & 0,05 & 0,07 & 0,05 & 0,04 & 0,02 & 0,03 & 0,04 & 0,06 & 0,03 & 0,06 & 0,04 & 0,04 & 0,03 & 0,02 & 0,03 \\
\hline $\mathrm{A} 12 \mathrm{O} 3$ & 20,75 & 20,86 & 20,65 & 20,54 & 20,83 & 20,65 & 21 & 20,56 & 20,93 & 20,84 & 20,74 & 20,76 & 21,01 & 20,7 & 20,69 & 20,63 & 20,54 & 20,73 & 20,32 & 20,71 & 20,72 \\
\hline $\mathrm{Cr} 2 \mathrm{O} 3$ & 0 & 0 & 0 & 0 & 0 & 0 & 0 & 0 & 0 & 0 & 0 & 0 & 0 & 0 & 0 & 0 & 0 & 0 & 0 & 0 & 0 \\
\hline $\mathrm{Fe} 2 \mathrm{O} 3$ & 0 & 0 & 0 & 0 & 0 & 0 & 0 & 0 & 0 & 0 & 0 & 0 & 0 & 0 & 0 & 0 & 0 & 0 & 0 & 0 & 0 \\
\hline $\mathrm{FeO}$ & 23,63 & 24,16 & 23,86 & 24 & 24,61 & 24,87 & 23,86 & 24,42 & 24,32 & 24,23 & 24,45 & 24,75 & 24,66 & 24,02 & 24,22 & 24 & 23,83 & 22,94 & 24,61 & 24,27 & 24,59 \\
\hline $\mathrm{MnO}$ & 1,96 & 1,83 & 1,9 & 1,91 & 1,89 & 1,86 & 1,87 & 1,79 & 1,83 & 1,83 & 1,87 & 1,86 & 1,86 & 1,88 & 1,8 & 1,9 & 1,85 & 1,79 & 1,93 & 1,85 & 2,09 \\
\hline $\mathrm{MgO}$ & 6,54 & 6,78 & 6,87 & 6,69 & 6,88 & 6,9 & 6,8 & 6,76 & 6,99 & 6,81 & 6,98 & 6,72 & 7,04 & 6,8 & 7 & 6,61 & 6,99 & 6,83 & 6,14 & 6,89 & 7,06 \\
\hline $\mathrm{CaO}$ & 7,48 & 6,62 & 6,4 & 6,72 & 6,74 & 6,71 & 6,65 & 6,72 & 6,8 & 6,77 & 6,71 & 6,77 & 6,36 & 6,58 & 6,61 & 6,5 & 6,73 & 6,66 & 6,59 & 6,71 & 6,7 \\
\hline $\mathrm{Na} 2 \mathrm{O}$ & 0 & 0 & 0 & 0 & 0 & 0 & 0 & 0 & 0 & 0 & 0 & 0 & 0 & 0 & 0 & 0 & 0 & 0 & 0 & 0 & 0 \\
\hline $\mathrm{K} 2 \mathrm{O}$ & 0 & 0 & 0 & 0 & 0 & 0 & 0 & 0 & 0 & 0 & 0 & 0 & 0 & 0 & 0 & 0 & 0 & 0 & 0 & 0 & 0 \\
\hline
\end{tabular}

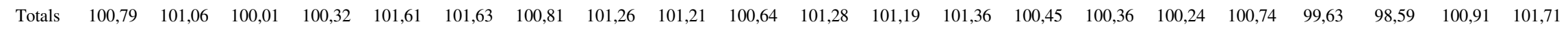

\begin{tabular}{|c|c|c|c|c|c|c|c|c|c|c|c|c|c|c|c|c|c|c|c|c|c|}
\hline Oxygens & 12 & 12 & 12 & 12 & 12 & 12 & 12 & 12 & 12 & 12 & 12 & 12 & 12 & 12 & 12 & 12 & 12 & 12 & 12 & 12 & 12 \\
\hline $\mathrm{Si}$ & 3,093 & 3,107 & 3,102 & 3,107 & 3,088 & 3,09 & 3,099 & 3,117 & 3,074 & 3,078 & 3,09 & 3,082 & 3,077 & 3,101 & 3,079 & 3,116 & 3,115 & 3,127 & 3,069 & 3,095 & 3,082 \\
\hline $\mathrm{Ti}$ & 0,002 & 0,002 & 0,003 & 0,002 & 0,003 & 0,003 & 0,003 & 0,004 & 0,003 & 0,002 & 0,001 & 0,001 & 0,002 & 0,003 & 0,002 & 0,003 & 0,002 & 0,002 & 0,002 & 0,001 & 0,002 \\
\hline $\mathrm{Al}$ & 1,873 & 1,875 & 1,875 & 1,862 & 1,868 & 1,853 & 1,89 & 1,846 & 1,883 & 1,886 & 1,864 & 1,872 & 1,887 & 1,873 & 1,877 & 1,869 & 1,851 & 1,879 & 1,887 & 1,867 & 1,858 \\
\hline $\mathrm{Cr}$ & 0 & 0 & 0 & 0 & 0 & 0 & 0 & 0 & 0 & 0 & 0 & 0 & 0 & 0 & 0 & 0 & 0 & 0 & 0 & 0 & 0 \\
\hline $\mathrm{Fe} 3$ & 0 & 0 & 0 & 0 & 0 & 0 & 0 & 0 & 0 & 0 & 0 & 0 & 0 & 0 & 0 & 0 & 0 & 0 & 0 & 0 & 0 \\
\hline $\mathrm{Fe} 2$ & 1,513 & 1,54 & 1,537 & 1,544 & 1,565 & 1,584 & 1,523 & 1,556 & 1,552 & 1,555 & 1,559 & 1,583 & 1,572 & 1,541 & 1,559 & 1,542 & 1,523 & 1,476 & 1,621 & 1,553 & 1,564 \\
\hline $\mathrm{Mn}$ & 0,127 & 0,118 & 0,124 & 0,125 & 0,122 & 0,12 & 0,121 & 0,116 & 0,118 & 0,119 & 0,121 & 0,121 & 0,12 & 0,122 & 0,117 & 0,124 & 0,12 & 0,116 & 0,129 & 0,12 & 0,135 \\
\hline $\mathrm{Mg}$ & 0,746 & 0,77 & 0,789 & 0,767 & 0,78 & 0,783 & 0,773 & 0,768 & 0,795 & 0,778 & 0,793 & 0,766 & 0,8 & 0,778 & 0,802 & 0,757 & 0,796 & 0,782 & 0,721 & 0,785 & 0,801 \\
\hline $\mathrm{Ca}$ & 0,614 & 0,541 & 0,529 & 0,554 & 0,549 & 0,548 & 0,544 & 0,549 & 0,556 & 0,557 & 0,548 & 0,555 & 0,519 & 0,541 & 0,545 & 0,535 & 0,551 & 0,549 & 0,556 & 0,55 & 0,546 \\
\hline $\mathrm{Na}$ & 0 & 0 & 0 & 0 & 0 & 0 & 0 & 0 & 0 & 0 & 0 & 0 & 0 & 0 & 0 & 0 & 0 & 0 & 0 & 0 & 0 \\
\hline $\mathrm{K}$ & 0 & 0 & 0 & 0 & 0 & 0 & 0 & 0 & 0 & 0 & 0 & 0 & 0 & 0 & 0 & 0 & 0 & 0 & 0 & 0 & 0 \\
\hline Sum & 7,968 & 7,954 & 7,958 & 7,96 & 7,976 & 7,981 & 7,953 & 7,956 & 7,982 & 7,977 & 7,977 & 7,981 & 7,977 & 7,96 & 7,981 & 7,946 & 7,958 & 7,932 & 7,985 & 7,971 & 7,988 \\
\hline
\end{tabular}


ALFE71c - Biotita

\begin{tabular}{|c|c|c|c|c|c|c|c|c|c|c|c|c|c|}
\hline Sample & 101 & 102 & 103 & 104 & 201 & 202 & 203 & 204 & 301 & 302 & 303 & 304 & 305 \\
\hline Min & bi & bi & bi & bi & bi & $\mathrm{bi}$ & bi & bi & bi & bi & bi & bi & bi \\
\hline $\mathrm{SiO} 2$ & 38,01 & 38 & 34,4 & 38,63 & 38,11 & 38,27 & 38,08 & 38,39 & 37,92 & 37,72 & 37,55 & 37,52 & 37,56 \\
\hline $\mathrm{TiO} 2$ & 4,23 & 4,25 & 3,88 & 4,34 & 4,72 & 4,54 & 4,51 & 4,56 & 4,93 & 5,17 & 5,15 & 4,8 & 5,18 \\
\hline $\mathrm{A} 12 \mathrm{O} 3$ & 16,83 & 16,32 & 15,79 & 17,62 & 17,75 & 16,55 & 16,2 & 16,59 & 16,27 & 16,56 & 16,27 & 16,35 & 16,78 \\
\hline $\mathrm{Cr} 2 \mathrm{O} 3$ & 0 & 0 & 0 & 0 & 0 & 0 & 0 & 0 & 0 & 0 & 0 & 0 & 0 \\
\hline $\mathrm{Fe} 2 \mathrm{O} 3$ & 0 & 0 & 0 & 0 & 0 & 0 & 0 & 0 & 0 & 0 & 0 & 0 & 0 \\
\hline $\mathrm{FeO}$ & 17,33 & 16,8 & 16,49 & 16,16 & 16,06 & 17,9 & 18,42 & 18,24 & 19,47 & 18,63 & 18,36 & 19,14 & 18,9 \\
\hline $\mathrm{MnO}$ & 0 & 0 & 0 & 0 & 0 & 0 & 0 & 0 & 0 & 0 & 0 & 0 & 0 \\
\hline $\mathrm{MgO}$ & 12,9 & 12,87 & 10,91 & 11,65 & 12,32 & 12,08 & 12,13 & 11,84 & 11,2 & 10,51 & 11,38 & 11,28 & 11,45 \\
\hline $\mathrm{CaO}$ & 0 & 0 & 0 & 0 & 0 & 0 & 0 & 0 & 0 & 0 & 0 & 0 & 0 \\
\hline $\mathrm{Na} 2 \mathrm{O}$ & 0 & 0 & 0 & 0 & 0 & 0 & 0 & 0 & 0 & 0 & 0 & 0 & 0 \\
\hline $\mathrm{K} 2 \mathrm{O}$ & 10,54 & 10,42 & 9,41 & 9,94 & 10,17 & 10,12 & 10,14 & 10,21 & 10,22 & 10,18 & 10,12 & 10,14 & 10,1 \\
\hline Totals & 99,85 & 98,66 & 90,88 & 98,34 & 99,13 & 99,45 & 99,47 & 99,82 & 100,01 & 98,76 & 98,83 & 99,24 & 99,97 \\
\hline Oxygens & 11 & 11 & 11 & 11 & 11 & 11 & 11 & 11 & 11 & 11 & 11 & 11 & 11 \\
\hline $\mathrm{Si}$ & 2,74 & 2,766 & 2,73 & 2,792 & 2,74 & 2,769 & 2,764 & 2,772 & 2,753 & 2,762 & 2,747 & 2,743 & 2,72 \\
\hline $\mathrm{Ti}$ & 0,229 & 0,233 & 0,232 & 0,236 & 0,255 & 0,247 & 0,246 & 0,247 & 0,269 & 0,284 & 0,283 & 0,264 & 0,282 \\
\hline $\mathrm{Al}$ & 1,431 & 1,4 & 1,477 & 1,502 & 1,505 & 1,411 & 1,387 & 1,412 & 1,393 & 1,43 & 1,403 & 1,409 & 1,433 \\
\hline $\mathrm{Cr}$ & 0 & 0 & 0 & 0 & 0 & 0 & 0 & 0 & 0 & 0 & 0 & 0 & 0 \\
\hline $\mathrm{Fe} 3$ & 0 & 0 & 0 & 0 & 0 & 0 & 0 & 0 & 0 & 0 & 0 & 0 & 0 \\
\hline $\mathrm{Fe} 2$ & 1,045 & 1,023 & 1,094 & 0,977 & 0,966 & 1,083 & 1,118 & 1,101 & 1,182 & 1,141 & 1,123 & 1,17 & 1,144 \\
\hline $\mathrm{Mn}$ & 0 & 0 & 0 & 0 & 0 & 0 & 0 & 0 & 0 & 0 & 0 & 0 & 0 \\
\hline $\mathrm{Mg}$ & 1,386 & 1,396 & 1,291 & 1,255 & 1,32 & 1,302 & 1,312 & 1,274 & 1,212 & 1,146 & 1,241 & 1,229 & 1,236 \\
\hline $\mathrm{Ca}$ & 0 & 0 & 0 & 0 & 0 & 0 & 0 & 0 & 0 & 0 & 0 & 0 & 0 \\
\hline $\mathrm{Na}$ & 0 & 0 & 0 & 0 & 0 & 0 & 0 & 0 & 0 & 0 & 0 & 0 & 0 \\
\hline K & 0,969 & 0,968 & 0,953 & 0,917 & 0,933 & 0,934 & 0,939 & 0,94 & 0,947 & 0,951 & 0,944 & 0,946 & 0,933 \\
\hline Sum & 7,8 & 7,786 & 7,777 & 7,679 & 7,72 & 7,747 & 7,767 & 7,746 & 7,756 & 7,715 & 7,741 & 7,762 & 7,749 \\
\hline
\end{tabular}


ALFE71c - Granada

\begin{tabular}{|c|c|c|c|c|c|c|c|c|c|c|c|c|}
\hline Sample & 101 & 102 & 103 & 104 & 105 & 106 & 107 & 108 & 109 & 110 & 111 & 112 \\
\hline Min & $\mathrm{g}$ & g & $\mathrm{g}$ & $\mathrm{g}$ & $\mathrm{g}$ & g & $\mathrm{g}$ & g & g & $\mathrm{g}$ & g & g \\
\hline $\mathrm{SiO} 2$ & 38.84 & 39.00 & 37.61 & 39.15 & 39.25 & 38.85 & 39.12 & 39.30 & 39.25 & 39.04 & 39.51 & 39.31 \\
\hline $\mathrm{TiO} 2$ & 0.02 & 0.02 & 0.04 & 0.02 & 0.01 & 0.03 & 0.06 & 0.00 & 0.05 & 0.01 & 0.01 & 0.07 \\
\hline $\mathrm{Al} 2 \mathrm{O} 3$ & 21.96 & 22.68 & 21.05 & 22.59 & 22.27 & 22.17 & 22.08 & 22.53 & 22.35 & 22.59 & 22.43 & 22.70 \\
\hline $\mathrm{Cr} 2 \mathrm{O} 3$ & 0.00 & 0.00 & 0.00 & 0.00 & 0.00 & 0.00 & 0.00 & 0.00 & 0.00 & 0.00 & 0.00 & 0.00 \\
\hline $\mathrm{Fe} 2 \mathrm{O} 3$ & 0.00 & 0.45 & 0.00 & 0.00 & 0.00 & 0.00 & 0.00 & 0.00 & 0.31 & 0.11 & 0.00 & 0.00 \\
\hline $\mathrm{FeO}$ & 29.44 & 28.28 & 26.67 & 28.09 & 28.15 & 29.11 & 27.61 & 27.66 & 27.58 & 27.54 & 27.33 & 27.66 \\
\hline $\mathrm{MnO}$ & 3.35 & 2.66 & 2.52 & 2.22 & 2.24 & 2.54 & 2.22 & 2.07 & 2.09 & 2.04 & 2.06 & 2.14 \\
\hline $\mathrm{MgO}$ & 4.96 & 6.12 & 5.85 & 6.97 & 7.05 & 6.17 & 6.62 & 6.97 & 7.04 & 7.16 & 7.13 & 7.10 \\
\hline $\mathrm{CaO}$ & 2.88 & 3.72 & 3.36 & 2.92 & 2.73 & 2.79 & 3.77 & 3.76 & 3.69 & 3.37 & 3.64 & 2.96 \\
\hline $\mathrm{Na} 2 \mathrm{O}$ & 0.00 & 0.00 & 0.00 & 0.00 & 0.00 & 0.00 & 0.00 & 0.00 & 0.00 & 0.00 & 0.00 & 0.00 \\
\hline $\mathrm{K} 2 \mathrm{O}$ & 0.00 & 0.00 & 0.00 & 0.00 & 0.00 & 0.00 & 0.00 & 0.00 & 0.00 & 0.00 & 0.00 & 0.00 \\
\hline Totals & 101.46 & 102.93 & 97.10 & 101.96 & 101.71 & 101.67 & 101.49 & 102.30 & 102.35 & 101.85 & 102.10 & 101.94 \\
\hline Oxygens & 12.0 & 12.0 & 12.0 & 12.0 & 12.0 & 12.0 & 12.0 & 12.0 & 12.0 & 12.0 & 12.0 & 12.0 \\
\hline $\mathrm{Si}$ & 3.017 & 2.969 & 3.023 & 2.989 & 3.004 & 2.995 & 3.004 & 2.990 & 2.986 & 2.980 & 3.004 & 2.994 \\
\hline $\mathrm{Ti}$ & 0.001 & 0.001 & 0.002 & 0.001 & 0.001 & 0.002 & 0.004 & 0.000 & 0.003 & 0.000 & 0.000 & 0.004 \\
\hline $\mathrm{Al}$ & 2.011 & 2.035 & 1.996 & 2.034 & 2.009 & 2.015 & 1.999 & 2.021 & 2.005 & 2.033 & 2.011 & 2.038 \\
\hline $\mathrm{Cr}$ & 0.000 & 0.000 & 0.000 & 0.000 & 0.000 & 0.000 & 0.000 & 0.000 & 0.000 & 0.000 & 0.000 & 0.000 \\
\hline $\mathrm{Fe} 3$ & 0.000 & 0.025 & 0.000 & 0.000 & 0.000 & 0.000 & 0.000 & 0.000 & 0.017 & 0.006 & 0.000 & 0.000 \\
\hline $\mathrm{Fe} 2$ & 1.913 & 1.801 & 1.793 & 1.794 & 1.802 & 1.877 & 1.773 & 1.758 & 1.756 & 1.759 & 1.738 & 1.762 \\
\hline $\mathrm{Mn}$ & 0.221 & 0.171 & 0.171 & 0.143 & 0.145 & 0.166 & 0.145 & 0.134 & 0.134 & 0.132 & 0.133 & 0.138 \\
\hline $\mathrm{Mg}$ & 0.574 & 0.695 & 0.701 & 0.793 & 0.805 & 0.709 & 0.758 & 0.790 & 0.798 & 0.814 & 0.808 & 0.805 \\
\hline $\mathrm{Ca}$ & 0.240 & 0.303 & 0.289 & 0.239 & 0.224 & 0.231 & 0.310 & 0.307 & 0.301 & 0.276 & 0.296 & 0.242 \\
\hline $\mathrm{Na}$ & 0.000 & 0.000 & 0.000 & 0.000 & 0.000 & 0.000 & 0.000 & 0.000 & 0.000 & 0.000 & 0.000 & 0.000 \\
\hline $\mathrm{K}$ & 0.000 & 0.000 & 0.000 & 0.000 & 0.000 & 0.000 & 0.000 & 0.000 & 0.000 & 0.000 & 0.000 & 0.000 \\
\hline Sum & 7.977 & 8.000 & 7.976 & 7.993 & 7.991 & 7.995 & 7.993 & 8.000 & 8.000 & 8.000 & 7.990 & 7.983 \\
\hline
\end{tabular}


ALFE71c - Granada

\begin{tabular}{|c|c|c|c|c|c|c|c|c|c|c|c|c|c|c|c|c|c|}
\hline Sample & 201 & 202 & 203 & 204 & 205 & 206 & 207 & 208 & 209 & 210 & 301 & 302 & 303 & 304 & 305 & 306 & 307 \\
\hline Min & g & $\mathrm{g}$ & $\mathrm{g}$ & $\mathrm{g}$ & g & g & $\mathrm{g}$ & $\mathrm{g}$ & $\mathrm{g}$ & $\mathrm{g}$ & $\mathrm{g}$ & $\mathrm{g}$ & g & $\mathrm{g}$ & $\mathrm{g}$ & $\mathrm{g}$ & $\mathrm{g}$ \\
\hline $\mathrm{SiO} 2$ & 39.30 & 39.02 & 39.26 & 38.90 & 39.03 & 39.15 & 39.17 & 38.93 & 39.24 & 39.18 & 38.65 & 38.71 & 38.40 & 39.14 & 38.94 & 39.13 & 39.15 \\
\hline TiO2 & 0.04 & 0.03 & 0.07 & 0.01 & 0.08 & 0.03 & 0.04 & 0.06 & 0.05 & 0.04 & 0.03 & 0.00 & 0.00 & 0.03 & 0.00 & 0.03 & 0.00 \\
\hline $\mathrm{Al} 2 \mathrm{O} 3$ & 22.56 & 22.23 & 22.54 & 22.55 & 22.53 & 22.79 & 22.54 & 22.30 & 22.37 & 22.03 & 21.81 & 22.20 & 22.14 & 22.04 & 22.26 & 22.51 & 22.69 \\
\hline $\mathrm{Cr} 2 \mathrm{O} 3$ & 0.00 & 0.00 & 0.00 & 0.00 & 0.00 & 0.00 & 0.00 & 0.00 & 0.00 & 0.00 & 0.00 & 0.00 & 0.00 & 0.00 & 0.00 & 0.00 & 0.00 \\
\hline $\mathrm{Fe} 2 \mathrm{O} 3$ & 0.18 & 0.00 & 0.32 & 0.71 & 0.00 & 0.01 & 0.00 & 0.05 & 0.00 & 0.00 & 0.00 & 0.34 & 0.32 & 0.00 & 0.08 & 0.34 & 0.00 \\
\hline $\mathrm{FeO}$ & 27.93 & 27.91 & 28.25 & 27.79 & 27.37 & 27.82 & 27.68 & 27.48 & 27.63 & 27.82 & 29.98 & 29.63 & 29.29 & 27.85 & 28.06 & 28.23 & 27.96 \\
\hline $\mathrm{MnO}$ & 2.08 & 2.10 & 1.98 & 2.00 & 2.04 & 2.08 & 2.14 & 2.18 & 2.19 & 2.27 & 3.44 & 3.10 & 2.98 & 2.63 & 2.52 & 2.45 & 2.35 \\
\hline $\mathrm{MgO}$ & 7.31 & 6.80 & 7.16 & 7.17 & 6.72 & 6.79 & 6.81 & 6.94 & 7.01 & 7.01 & 5.06 & 5.43 & 5.39 & 6.39 & 6.67 & 6.81 & 6.81 \\
\hline $\mathrm{CaO}$ & 3.09 & 3.10 & 3.12 & 3.06 & 3.83 & 3.76 & 3.70 & 3.54 & 3.28 & 2.99 & 2.66 & 3.00 & 3.13 & 3.29 & 3.16 & 3.09 & 2.91 \\
\hline $\mathrm{Na} 2 \mathrm{O}$ & 0.00 & 0.00 & 0.00 & 0.00 & 0.00 & 0.00 & 0.00 & 0.00 & 0.00 & 0.00 & 0.00 & 0.00 & 0.00 & 0.00 & 0.00 & 0.00 & 0.00 \\
\hline $\mathrm{K} 2 \mathrm{O}$ & 0.00 & 0.00 & 0.00 & 0.00 & 0.00 & 0.00 & 0.00 & 0.00 & 0.00 & 0.00 & 0.00 & 0.00 & 0.00 & 0.00 & 0.00 & 0.00 & 0.00 \\
\hline Totals & 102.49 & 101.18 & 102.69 & 102.18 & 101.59 & 102.43 & 102.08 & 101.48 & 101.78 & 101.33 & 101.62 & 102.39 & 101.65 & 101.37 & 101.70 & 102.60 & 101.87 \\
\hline Oxygens & 12.0 & 12.0 & 12.0 & 12.0 & 12.0 & 12.0 & 12.0 & 12.0 & 12.0 & 12.0 & 12.0 & 12.0 & 12.0 & 12.0 & 12.0 & 12.0 & 12.0 \\
\hline $\mathrm{Si}$ & 2.983 & 3.002 & 2.979 & 2.966 & 2.988 & 2.977 & 2.988 & 2.987 & 2.998 & 3.010 & 3.006 & 2.982 & 2.979 & 3.013 & 2.990 & 2.979 & 2.991 \\
\hline $\mathrm{Ti}$ & 0.002 & 0.002 & 0.004 & 0.001 & 0.004 & 0.002 & 0.002 & 0.003 & 0.003 & 0.002 & 0.002 & 0.000 & 0.000 & 0.002 & 0.000 & 0.002 & 0.000 \\
\hline $\mathrm{Al}$ & 2.019 & 2.017 & 2.016 & 2.027 & 2.034 & 2.043 & 2.026 & 2.017 & 2.015 & 1.995 & 2.000 & 2.016 & 2.024 & 2.000 & 2.015 & 2.020 & 2.043 \\
\hline $\mathrm{Cr}$ & 0.000 & 0.000 & 0.000 & 0.000 & 0.000 & 0.000 & 0.000 & 0.000 & 0.000 & 0.000 & 0.000 & 0.000 & 0.000 & 0.000 & 0.000 & 0.000 & 0.000 \\
\hline $\mathrm{Fe} 3$ & 0.010 & 0.000 & 0.018 & 0.040 & 0.000 & 0.000 & 0.000 & 0.002 & 0.000 & 0.000 & 0.000 & 0.019 & 0.018 & 0.000 & 0.004 & 0.019 & 0.000 \\
\hline $\mathrm{Fe} 2$ & 1.774 & 1.796 & 1.793 & 1.772 & 1.752 & 1.768 & 1.766 & 1.764 & 1.766 & 1.787 & 1.950 & 1.910 & 1.900 & 1.793 & 1.803 & 1.798 & 1.786 \\
\hline $\mathrm{Mn}$ & 0.134 & 0.137 & 0.128 & 0.129 & 0.132 & 0.134 & 0.138 & 0.142 & 0.142 & 0.147 & 0.226 & 0.202 & 0.196 & 0.171 & 0.164 & 0.158 & 0.152 \\
\hline $\mathrm{Mg}$ & 0.827 & 0.780 & 0.809 & 0.815 & 0.766 & 0.770 & 0.774 & 0.793 & 0.798 & 0.803 & 0.587 & 0.623 & 0.623 & 0.733 & 0.763 & 0.772 & 0.775 \\
\hline $\mathrm{Ca}$ & 0.251 & 0.255 & 0.253 & 0.250 & 0.314 & 0.306 & 0.302 & 0.291 & 0.269 & 0.246 & 0.222 & 0.247 & 0.260 & 0.272 & 0.260 & 0.252 & 0.238 \\
\hline $\mathrm{Na}$ & 0.000 & 0.000 & 0.000 & 0.000 & 0.000 & 0.000 & 0.000 & 0.000 & 0.000 & 0.000 & 0.000 & 0.000 & 0.000 & 0.000 & 0.000 & 0.000 & 0.000 \\
\hline $\mathrm{K}$ & 0.000 & 0.000 & 0.000 & 0.000 & 0.000 & 0.000 & 0.000 & 0.000 & 0.000 & 0.000 & 0.000 & 0.000 & 0.000 & 0.000 & 0.000 & 0.000 & 0.000 \\
\hline Sum & 8.000 & 7.988 & 8.000 & 8.000 & 7.991 & 8.000 & 7.997 & 8.000 & 7.991 & 7.991 & 7.993 & 8.000 & 8.000 & 7.985 & 8.000 & 8.000 & 7.987 \\
\hline
\end{tabular}


ALFE71c - Plagioclásio

\begin{tabular}{|c|c|c|c|c|c|c|c|c|c|c|c|c|c|c|}
\hline Sample & 101 & 102 & 103 & 104 & 105 & 106 & 107 & 201 & 202 & 203 & 301 & 302 & 303 & 304 \\
\hline Min & fsp & fsp & fsp & fsp & fsp & fsp & fsp & fsp & fsp & fsp & fsp & fsp & fsp & fsp \\
\hline $\mathrm{SiO} 2$ & 62,25 & 62,11 & 63,07 & 62,3 & 62,73 & 62,37 & 64,75 & 63,32 & 63,52 & 64,25 & 62,43 & 62,52 & 62,4 & 62,8 \\
\hline $\mathrm{TiO} 2$ & 0 & 0 & 0 & 0 & 0 & 0 & 0 & 0 & 0 & 0 & 0 & 0 & 0 & 0 \\
\hline $\mathrm{A} 12 \mathrm{O} 3$ & 23,5 & 23,56 & 23,46 & 23,74 & 23,25 & 23,48 & 22,36 & 21,99 & 23,09 & 22,83 & 23,62 & 23,4 & 23,44 & 23,19 \\
\hline $\mathrm{Cr} 2 \mathrm{O} 3$ & 0 & 0 & 0 & 0 & 0 & 0 & 0 & 0 & 0 & 0 & 0 & 0 & 0 & 0 \\
\hline $\mathrm{Fe} 2 \mathrm{O} 3$ & 0 & 0 & 0 & 0 & 0 & 0 & 0 & 0 & 0 & 0 & 0 & 0 & 0 & 0 \\
\hline $\mathrm{FeO}$ & 0 & 0 & 0 & 0 & 0 & 0 & 0 & 0 & 0 & 0 & 0 & 0 & 0 & 0 \\
\hline $\mathrm{MnO}$ & 0 & 0 & 0 & 0 & 0 & 0 & 0 & 0 & 0 & 0 & 0 & 0 & 0 & 0 \\
\hline $\mathrm{MgO}$ & 0 & 0 & 0 & 0 & 0 & 0 & 0 & 0 & 0 & 0 & 0 & 0 & 0 & 0 \\
\hline $\mathrm{CaO}$ & 5,9 & 5,86 & 5,77 & 5,99 & 3,91 & 5,85 & 4,11 & 4,28 & 5,42 & 5,25 & 5,66 & 5,49 & 5,68 & 5,31 \\
\hline $\mathrm{Na} 2 \mathrm{O}$ & 7,89 & 7,93 & 7,89 & 7,82 & 7,78 & 7,96 & 8,21 & 8,56 & 8,03 & 8,28 & 7,9 & 7,83 & 7,97 & 8,23 \\
\hline $\mathrm{K} 2 \mathrm{O}$ & 0 & 0 & 0 & 0 & 1 & 0 & 0 & 0 & 0 & 0 & 0 & 0 & 0 & 0 \\
\hline Totals & 100 & 100 & 101 & 100 & 99 & 100 & 100 & 98 & 100,29 & 100,83 & 99,89 & 99,65 & 99,93 & 99,7 \\
\hline Oxygens & 8 & 8 & 8 & 8 & 8 & 8 & 8 & 8 & 8 & 8 & 8 & 8 & 8 & 8 \\
\hline $\mathrm{Si}$ & 2,763 & 2,759 & 2,776 & 2,755 & 2,803 & 2,764 & 2,853 & 2,837 & 3 & 3 & 3 & 3 & 3 & 3 \\
\hline $\mathrm{Ti}$ & 0 & 0 & 0 & 0 & 0 & 0 & 0 & 0 & 0 & 0 & 0 & 0 & 0 & 0 \\
\hline $\mathrm{Al}$ & 1,23 & 1,234 & 1,217 & 1,238 & 1,224 & 1,227 & 1,162 & 1,161 & 1,199 & 1,179 & 1,234 & 1,225 & 1,226 & 1,212 \\
\hline $\mathrm{Cr}$ & 0 & 0 & 0 & 0 & 0 & 0 & 0 & 0 & 0 & 0 & 0 & 0 & 0 & 0 \\
\hline $\mathrm{Fe} 3$ & 0,001 & 0 & 0 & 0,001 & 0,003 & 0,001 & 0 & 0 & 0,001 & 0,001 & 0,001 & 0,002 & 0,001 & 0 \\
\hline $\mathrm{Fe} 2$ & 0 & 0 & 0 & 0 & 0 & 0 & 0 & 0 & 0 & 0 & 0 & 0 & 0 & 0 \\
\hline $\mathrm{Mn}$ & 0 & 0 & 0 & 0 & 0 & 0 & 0 & 0 & 0 & 0 & 0 & 0 & 0 & 0 \\
\hline $\mathrm{Mg}$ & 0 & 0 & 0 & 0 & 0 & 0 & 0 & 0 & 0 & 0 & 0 & 0 & 0 & 0 \\
\hline $\mathrm{Ca}$ & 0,28 & 0,279 & 0,272 & 0,284 & 0,187 & 0,278 & 0,194 & 0,205 & 0,256 & 0,246 & 0,269 & 0,261 & 0,27 & 0,252 \\
\hline $\mathrm{Na}$ & 0,679 & 0,683 & 0,674 & 0,67 & 0,674 & 0,684 & 0,701 & 0,743 & 0,686 & 0,703 & 0,679 & 0,674 & 0,685 & 0,708 \\
\hline K & 0,018 & 0,023 & 0,025 & 0,025 & 0,058 & 0,02 & 0,011 & 0,015 & 0,012 & 0,012 & 0,015 & 0,023 & 0,025 & 0,01 \\
\hline Sum & 4,971 & 4,978 & 4,965 & 4,973 & 4,949 & 4,974 & 4,922 & 4,962 & 4,952 & 4,954 & 4,964 & 4,96 & 4,974 & 4,967 \\
\hline
\end{tabular}


ALFE71e - Biotita

\begin{tabular}{|c|c|c|c|c|c|c|c|c|c|c|c|c|c|c|c|c|c|c|c|c|c|}
\hline Sample & 101 & 102 & 103 & 201 & 202 & 203 & 301 & 302 & 303 & 401 & 402 & 403 & 404 & 501 & 502 & 503 & 504 & 601 & 602 & 603 & 604 \\
\hline Min & bi & bi & bi & bi & bi & bi & bi & bi & bi & bi & bi & bi & bi & bi & bi & bi & bi & bi & bi & bi & bi \\
\hline $\mathrm{SiO} 2$ & 37,73 & 37,6 & 70,51 & 68,73 & 37,05 & 37,79 & 37,67 & 37,77 & 38,46 & 36,84 & 37,4 & 38,58 & 37,86 & 37,22 & 38,11 & 38,2 & 37,69 & 37,34 & 37,48 & 37,57 & 37,62 \\
\hline $\mathrm{TiO} 2$ & 4,63 & 4,72 & 2,46 & 2,86 & 4,95 & 4,85 & 4,81 & 4,76 & 4,62 & 4,73 & 4,4 & 4,92 & 4,57 & 4,77 & 5 & 5 & 4,88 & 4,71 & 4,71 & 4,78 & 4,89 \\
\hline $\mathrm{Al} 2 \mathrm{O} 3$ & 15,94 & 15,42 & 7,8 & 8,59 & 16,21 & 15,8 & 15,6 & 15,59 & 15,22 & 16,1 & 16,04 & 15,19 & 15,66 & 15,52 & 15,5 & 15,79 & 15,94 & 15,83 & 15,85 & 15,7 & 15,83 \\
\hline $\mathrm{Cr} 2 \mathrm{O} 3$ & 0 & 0 & 0 & 0 & 0 & 0 & 0 & 0 & 0 & 0 & 0 & 0 & 0 & 0 & 0 & 0 & 0 & 0 & 0 & 0 & 0 \\
\hline $\mathrm{Fe} 2 \mathrm{O} 3$ & 0 & 0 & 0 & 0 & 0 & 0 & 0 & 0 & 0 & 0 & 0 & 0 & 0 & 0 & 0 & 0 & 0 & 0 & 0 & 0 & 0 \\
\hline $\mathrm{FeO}$ & 18,24 & 18,02 & 10,02 & 9,87 & 18,05 & 17,47 & 18,43 & 18,09 & 18,15 & 17,83 & 17,86 & 17,52 & 17,97 & 18,36 & 18,25 & 18,2 & 17,82 & 18,03 & 17,61 & 17,76 & 17,92 \\
\hline $\mathrm{MnO}$ & 0 & 0 & 0 & 0 & 0 & 0 & 0 & 0 & 0 & 0 & 0 & 0 & 0 & 0 & 0 & 0 & 0 & 0 & 0 & 0 & 0 \\
\hline $\mathrm{MgO}$ & 12,54 & 12,61 & 6,23 & 6,21 & 11,99 & 12,62 & 12,2 & 12,4 & 12,92 & 12,21 & 12,29 & 12,88 & 12,2 & 11,95 & 12,31 & 12,11 & 12,54 & 12,36 & 12,38 & 12,42 & 12,3 \\
\hline $\mathrm{CaO}$ & 0 & 0 & 0 & 0 & 0 & 0 & 0 & 0 & 0 & 0 & 0 & 0 & 0 & 0 & 0 & 0 & 0 & 0 & 0 & 0 & 0 \\
\hline $\mathrm{Na} 2 \mathrm{O}$ & 0 & 0 & 0 & 0 & 0 & 0 & 0 & 0 & 0 & 0 & 0 & 0 & 0 & 0 & 0 & 0 & 0 & 0 & 0 & 0 & 0 \\
\hline $\mathrm{K} 2 \mathrm{O}$ & 10 & 10 & 5 & 6 & 10 & 10 & 10 & 10 & 10,16 & 10,26 & 10,08 & 10,18 & 10,09 & 10,1 & 10,32 & 10,24 & 10,35 & 10,03 & 10,21 & 10,49 & 10,37 \\
\hline Totals & 99,34 & 98,71 & 102,02 & 102,09 & 98,41 & 98,8 & 98,84 & 98,9 & 99,53 & 97,96 & 98,06 & 99,28 & 98,34 & 97,91 & 99 & 100 & 99,22 & 98,29 & 98,24 & 98,72 & 98,93 \\
\hline Oxygens & 11 & 11 & 11 & 11 & 11 & 11 & 11 & 11 & 11 & 11 & 11 & 11 & 11 & 11 & 11 & 11 & 11 & 11 & 11 & 11 & 11 \\
\hline $\mathrm{Si}$ & 2,747 & 2,757 & 4,324 & 4,243 & 2,723 & 2,757 & 2,758 & 2,762 & 2,789 & 2,721 & 2,752 & 2,796 & 2,778 & 2,754 & 2,778 & 2,77 & 2,744 & 2,745 & 2,753 & 2,752 & 2,749 \\
\hline $\mathrm{Ti}$ & 0,254 & 0,26 & 0,113 & 0,133 & 0,274 & 0,266 & 0,265 & 0,262 & 0,252 & 0,263 & 0,244 & 0,268 & 0,252 & 0,266 & 0,258 & 0,274 & 0,267 & 0,26 & 0,26 & 0,263 & 0,269 \\
\hline $\mathrm{Al}$ & 1 & 1 & 1 & 1 & 1 & 1 & 1 & 1 & 1,301 & 1,402 & 1,392 & 1,298 & 1,355 & 1,354 & 1,332 & 1,35 & 1,368 & 1,372 & 1,372 & 1,356 & 1,364 \\
\hline $\mathrm{Cr}$ & 0 & 0 & 0 & 0 & 0 & 0 & 0 & 0 & 0 & 0 & 0 & 0 & 0 & 0 & 0 & 0 & 0 & 0 & 0 & 0 & 0 \\
\hline $\mathrm{Fe} 3$ & 0 & 0 & 0 & 0 & 0 & 0 & 0 & 0 & 0 & 0 & 0 & 0 & 0 & 0 & 0 & 0 & 0 & 0 & 0 & 0 & 0 \\
\hline $\mathrm{Fe} 2$ & 1,11 & 1,105 & 0,514 & 0,509 & 1,11 & 1,066 & 1,129 & 1,107 & 1,101 & 1,101 & 1,099 & 1,062 & 1,103 & 1,136 & 1,113 & 1,104 & 1,085 & 1,108 & 1,082 & 1,088 & 1,095 \\
\hline $\mathrm{Mn}$ & 0 & 0 & 0 & 0 & 0 & 0 & 0 & 0 & 0 & 0 & 0 & 0 & 0 & 0 & 0 & 0 & 0 & 0 & 0 & 0 & 0 \\
\hline $\mathrm{Mg}$ & 1,36 & 1,378 & 0,569 & 0,572 & 1,314 & 1,372 & 1,332 & 1,351 & 1,396 & 1,344 & 1,348 & 1,391 & 1,334 & 1,318 & 1,337 & 1,308 & 1,361 & 1,354 & 1,355 & 1,356 & 1,34 \\
\hline $\mathrm{Ca}$ & 0 & 0 & 0 & 0 & 0 & 0 & 0 & 0 & 0 & 0 & 0 & 0 & 0 & 0 & 0 & 0 & 0 & 0 & 0 & 0 & 0 \\
\hline $\mathrm{Na}$ & 0 & 0 & 0 & 0 & 0 & 0 & 0 & 0 & 0 & 0 & 0 & 0 & 0 & 0 & 0 & 0 & 0 & 0 & 0 & 0 & 0 \\
\hline K & 0,952 & 0,968 & 0,391 & 0,459 & 0,952 & 0,955 & 0,947 & 0,959 & 0,94 & 0,967 & 0,947 & 0,941 & 0,944 & 0,953 & 0,96 & 0,948 & 0,961 & 0,941 & 0,956 & 0,98 & 0,967 \\
\hline Sum & 7,792 & 7,801 & 6,476 & 6,541 & 7,778 & 7,775 & 7,777 & 7,785 & 7,779 & 7,799 & 7,782 & 7,758 & 7,766 & 7,781 & 7,778 & 7,755 & 7,786 & 7,78 & 7,779 & 7,797 & 7,784 \\
\hline
\end{tabular}


ALFE71e - Granada

\begin{tabular}{|c|c|c|c|c|c|c|c|c|c|c|c|c|c|c|c|c|c|}
\hline Sample & 101 & 102 & 103 & 104 & 105 & 106 & 107 & 108 & 109 & 110 & 111 & 112 & 113 & 114 & 115 & 116 & 117 \\
\hline Min & $\mathrm{g}$ & $\mathrm{g}$ & $\mathrm{g}$ & $\mathrm{g}$ & $\mathrm{g}$ & $\mathrm{g}$ & $\mathrm{g}$ & $\mathrm{g}$ & $\mathrm{g}$ & $\mathrm{g}$ & $\mathrm{g}$ & $\mathrm{g}$ & $\mathrm{g}$ & $\mathrm{g}$ & $\mathrm{g}$ & $\mathrm{g}$ & $\mathrm{g}$ \\
\hline $\mathrm{SiO} 2$ & 39,07 & 39,13 & 39,34 & 39,29 & 38,88 & 39,3 & 39,16 & 39,18 & 38,95 & 39,27 & 39,37 & 38,85 & 39,12 & 39,38 & 38,99 & 39,11 & 39,19 \\
\hline $\mathrm{TiO} 2$ & 0,01 & 0 & 0,01 & 0,05 & 0,04 & 0,06 & 0,01 & 0 & 0,05 & 0 & 0,04 & 0,02 & 0 & 0 & 0,02 & 0,03 & 0,02 \\
\hline $\mathrm{Al} 2 \mathrm{O} 3$ & 22,26 & 22,38 & 22,36 & 22,4 & 22,3 & 22,79 & 22,63 & 22,25 & 22,44 & 22,71 & 22,61 & 22,86 & 22,51 & 22,47 & 22,79 & 22,87 & 22,25 \\
\hline $\mathrm{Cr} 2 \mathrm{O} 3$ & 0 & 0 & 0 & 0 & 0 & 0 & 0 & 0 & 0 & 0 & 0 & 0 & 0 & 0 & 0 & 0 & 0 \\
\hline $\mathrm{Fe} 2 \mathrm{O} 3$ & 0 & 0 & 0,33 & 0 & 0 & 0 & 0 & 0 & 0 & 0 & 0 & 0 & 0 & 0 & 0 & 0 & 0 \\
\hline $\mathrm{FeO}$ & 28,17 & 27,91 & 28,07 & 28,03 & 27,25 & 27,18 & 27,59 & 27,44 & 28,02 & 28,29 & 27,78 & 27,66 & 27,29 & 28,37 & 27,13 & 28,84 & 28,78 \\
\hline $\mathrm{MnO}$ & 1,62 & 1,57 & 1,53 & 1,51 & 1,44 & 1,44 & 1,45 & 1,42 & 1,47 & 1,47 & 1,42 & 1,52 & 1,53 & 1,5 & 1,54 & 1,61 & 1,7 \\
\hline $\mathrm{MgO}$ & 7,04 & 7,14 & 7,33 & 7 & 7,14 & 7,29 & 7,55 & 7,81 & 7,95 & 8,11 & 8,2 & 8,05 & 8,22 & 7,94 & 7,69 & 7,39 & 6,3 \\
\hline $\mathrm{CaO}$ & 3 & 3 & 3 & 4 & 4 & 4 & 3 & 3 & 2,13 & 1,81 & 1,61 & 1,75 & 1,67 & 1,81 & 1,99 & 2,31 & 2,81 \\
\hline $\mathrm{Na} 2 \mathrm{O}$ & 0 & 0 & 0 & 0 & 0 & 0 & 0 & 0 & 0 & 0 & 0 & 0 & 0 & 0 & 0 & 0 & 0 \\
\hline $\mathrm{K} 2 \mathrm{O}$ & 0 & 0 & 0 & 0 & 0 & 0 & 0 & 0 & 0 & 0 & 0 & 0 & 0 & 0 & 0 & 0 & 0 \\
\hline Totals & 101,09 & 101,24 & 102,39 & 101,94 & 101,03 & 101,87 & 101,67 & 100,69 & 101 & 101,66 & 101,03 & 100,7 & 100,33 & 101,47 & 100,15 & 102,16 & 101,04 \\
\hline Oxygens & 12 & 12 & 12 & 12 & 12 & 12 & 12 & 12 & 12 & 12 & 12 & 12 & 12 & 12 & 12 & 12 & 12 \\
\hline $\mathrm{Si}$ & 3,004 & 3,001 & 2,989 & 2,996 & 2,988 & 2,987 & 2,985 & 3,008 & 2,987 & 2,99 & 3,006 & 2,98 & 3,005 & 3,005 & 3,001 & 2,976 & 3,021 \\
\hline $\mathrm{Ti}$ & 0,001 & 0 & 0,001 & 0,003 & 0,003 & 0,003 & 0 & 0 & 0,003 & 0 & 0,002 & 0,001 & 0 & 0 & 0,001 & 0,002 & 0,001 \\
\hline $\mathrm{Al}$ & 2,018 & 2,023 & 2,002 & 2,014 & 2,02 & 2,042 & 2,033 & 2,014 & 2,029 & 2,038 & 2,036 & 2,067 & 2,039 & 2,021 & 2,068 & 2,052 & 2,022 \\
\hline $\mathrm{Cr}$ & 0 & 0 & 0 & 0 & 0 & 0 & 0 & 0 & 0 & 0 & 0 & 0 & 0 & 0 & 0 & 0 & 0 \\
\hline $\mathrm{Fe} 3$ & 0 & 0 & 0,019 & 0 & 0 & 0 & 0 & 0 & 0 & 0 & 0 & 0 & 0 & 0 & 0 & 0 & 0 \\
\hline $\mathrm{Fe} 2$ & 1,811 & 1,79 & 1,783 & 1,788 & 1,749 & 1,728 & 1,759 & 1,762 & 1,797 & 1,801 & 1,774 & 1,774 & 1,753 & 1,81 & 1,747 & 1,835 & 1,855 \\
\hline $\mathrm{Mn}$ & 0,106 & 0,102 & 0,098 & 0,097 & 0,094 & 0,093 & 0,093 & 0,093 & 0,096 & 0,095 & 0,092 & 0,099 & 0,099 & 0,097 & 0,1 & 0,104 & 0,111 \\
\hline $\mathrm{Mg}$ & 0,807 & 0,816 & 0,83 & 0,796 & 0,818 & 0,826 & 0,858 & 0,893 & 0,909 & 0,92 & 0,933 & 0,92 & 0,941 & 0,903 & 0,882 & 0,838 & 0,723 \\
\hline $\mathrm{Ca}$ & 0,24 & 0,257 & 0,278 & 0,299 & 0,328 & 0,31 & 0,268 & 0,213 & 0,175 & 0,148 & 0,132 & 0,144 & 0,137 & 0,148 & 0,164 & 0,189 & 0,232 \\
\hline $\mathrm{Na}$ & 0 & 0 & 0 & 0 & 0 & 0 & 0 & 0 & 0 & 0 & 0 & 0 & 0 & 0 & 0 & 0 & 0 \\
\hline K & 0 & 0 & 0 & 0 & 0 & 0 & 0 & 0 & 0 & 0 & 0 & 0 & 0 & 0 & 0 & 0 & 0 \\
\hline Sum & 7,986 & 7,988 & 8 & 7,994 & 8 & 7,989 & 7,998 & 7,985 & 7,996 & 7,991 & 7,974 & 7,985 & 7,975 & 7,985 & 7,964 & 7,996 & 7,966 \\
\hline
\end{tabular}


ALFE71e - Granada

\begin{tabular}{|c|c|c|c|c|c|c|c|c|c|c|c|c|c|c|c|c|c|}
\hline Sample & 201 & 202 & 203 & 204 & 205 & 206 & 207 & 208 & 301 & 302 & 303 & 304 & 305 & 306 & 307 & 308 & 309 \\
\hline Min & $\mathrm{g}$ & $\mathrm{g}$ & $\mathrm{g}$ & $\mathrm{g}$ & $\mathrm{g}$ & $\mathrm{g}$ & $\mathrm{g}$ & $\mathrm{g}$ & $\mathrm{g}$ & $\mathrm{g}$ & $\mathrm{g}$ & $\mathrm{g}$ & $\mathrm{g}$ & $\mathrm{g}$ & $\mathrm{g}$ & $\mathrm{g}$ & $\mathrm{g}$ \\
\hline $\mathrm{SiO} 2$ & 38,87 & 38,99 & 39,33 & 38,93 & 39,06 & 39,01 & 39,42 & 39,03 & 38,92 & 38,79 & 36,83 & 38,88 & 38,99 & 38,85 & 39,11 & 38,75 & 38,65 \\
\hline $\mathrm{TiO} 2$ & 0,02 & 0,02 & 0 & 0,03 & 0,03 & 0,04 & 0,01 & 0,03 & 0 & 0,01 & 0,04 & 0,03 & 0,03 & 0,03 & 0 & 0,01 & 0,04 \\
\hline $\mathrm{Al} 2 \mathrm{O} 3$ & 22,82 & 22,53 & 22,61 & 22,48 & 22,45 & 22,29 & 22,18 & 22,56 & 21,98 & 22,2 & 22,5 & 22,3 & 22,38 & 22,29 & 22,37 & 22,27 & 22,12 \\
\hline $\mathrm{Cr} 2 \mathrm{O} 3$ & 0 & 0 & 0 & 0 & 0 & 0 & 0 & 0 & 0 & 0 & 0 & 0 & 0 & 0 & 0 & 0 & 0 \\
\hline $\mathrm{Fe} 2 \mathrm{O} 3$ & 0 & 0,17 & 0 & 0,72 & 0 & 0 & 0 & 0,48 & 0 & 0 & 0 & 0,01 & 0 & 0 & 0 & 0,23 & 0 \\
\hline $\mathrm{FeO}$ & 28,65 & 29,21 & 28,29 & 28,37 & 28,3 & 28,29 & 28,39 & 28,74 & 28,12 & 28,26 & 24,07 & 28,51 & 27,32 & 28 & 28,04 & 28,31 & 29,2 \\
\hline $\mathrm{MnO}$ & 1,73 & 1,67 & 1,6 & 1,57 & 1,59 & 1,64 & 1,57 & 1,64 & 1,81 & 1,86 & 1,52 & 1,84 & 1,76 & 1,75 & 1,81 & 1,81 & 1,97 \\
\hline $\mathrm{MgO}$ & 6 & 7 & 7 & 7 & 7 & 7 & 7 & 7 & 6,77 & 6,6 & 5,43 & 6,52 & 6,86 & 7 & 6,7 & 6,59 & 5,61 \\
\hline $\mathrm{CaO}$ & 3 & 3 & 3 & 3 & 3 & 3 & 3 & 3 & 3,01 & 3,41 & 3,16 & 3,53 & 3,12 & 3,2 & 3,34 & 3,48 & 3,58 \\
\hline $\mathrm{Na} 2 \mathrm{O}$ & 0 & 0 & 0 & 0 & 0 & 0 & 0 & 0 & 0 & 0 & 0 & 0 & 0 & 0 & 0 & 0 & 0 \\
\hline $\mathrm{K} 2 \mathrm{O}$ & 0 & 0 & 0 & 0 & 0 & 0 & 0 & 0 & 0 & 0 & 0 & 0 & 0 & 0 & 0 & 0 & 0 \\
\hline Totals & 101,31 & 102,23 & 101,74 & 102,15 & 101,17 & 101,07 & 101,53 & 102,44 & 100,61 & 101,14 & 93,54 & 101,62 & 100,46 & 101,12 & 101,36 & 101,45 & 101,16 \\
\hline Oxygens & 12 & 12 & 12 & 12 & 12 & 12 & 12 & 12 & 12 & 12 & 12 & 12 & 12 & 12 & 12 & 12 & 12 \\
\hline $\mathrm{Si}$ & 2,988 & 2,979 & 3 & 2,968 & 3 & 3,002 & 3,016 & 2,972 & 3,012 & 2,992 & 3,019 & 2,988 & 3,009 & 2,99 & 3,003 & 2,982 & 2,997 \\
\hline $\mathrm{Ti}$ & 0,001 & 0,001 & 0 & 0,001 & 0,002 & 0,002 & 0 & 0,001 & 0 & 0,001 & 0,002 & 0,002 & 0,002 & 0,002 & 0 & 0 & 0,003 \\
\hline $\mathrm{Al}$ & 2,068 & 2,029 & 2,033 & 2,02 & 2,032 & 2,022 & 2 & 2,025 & 2,005 & 2,019 & 2,175 & 2,02 & 2,036 & 2,023 & 2,024 & 2,021 & 2,022 \\
\hline $\mathrm{Cr}$ & 0 & 0 & 0 & 0 & 0 & 0 & 0 & 0 & 0 & 0 & 0 & 0 & 0 & 0 & 0 & 0 & 0 \\
\hline $\mathrm{Fe} 3$ & 0 & 0,01 & 0 & 0,041 & 0 & 0 & 0 & 0,027 & 0 & 0 & 0 & 0 & 0 & 0 & 0 & 0,013 & 0 \\
\hline $\mathrm{Fe} 2$ & 1,842 & 1,867 & 1,805 & 1,809 & 1,817 & 1,821 & 1,817 & 1,831 & 1,82 & 1,823 & 1,65 & 1,833 & 1,763 & 1,802 & 1,8 & 1,823 & 1,894 \\
\hline $\mathrm{Mn}$ & 0,112 & 0,108 & 0,104 & 0,102 & 0,104 & 0,107 & 0,102 & 0,105 & 0,119 & 0,121 & 0,105 & 0,12 & 0,115 & 0,114 & 0,118 & 0,118 & 0,129 \\
\hline $\mathrm{Mg}$ & 0,737 & 0,772 & 0,825 & 0,843 & 0,805 & 0,796 & 0,821 & 0,797 & 0,781 & 0,759 & 0,663 & 0,747 & 0,789 & 0,803 & 0,766 & 0,755 & 0,648 \\
\hline $\mathrm{Ca}$ & 0,23 & 0,234 & 0,216 & 0,215 & 0,223 & 0,237 & 0,226 & 0,241 & 0,249 & 0,282 & 0,277 & 0,291 & 0,258 & 0,264 & 0,275 & 0,287 & 0,298 \\
\hline $\mathrm{Na}$ & 0 & 0 & 0 & 0 & 0 & 0 & 0 & 0 & 0 & 0 & 0 & 0 & 0 & 0 & 0 & 0 & 0 \\
\hline $\mathrm{K}$ & 0 & 0 & 0 & 0 & 0 & 0 & 0 & 0 & 0 & 0 & 0 & 0 & 0 & 0 & 0 & 0 & 0 \\
\hline Sum & 7,977 & 8 & 7,983 & 8 & 7,983 & 7,985 & 7,983 & 8 & 7,986 & 7,998 & 7,892 & 8 & 7,971 & 7,997 & 7,985 & 8 & 7,99 \\
\hline
\end{tabular}


ALFE71e - Plagioclásio

\begin{tabular}{|c|c|c|c|c|c|c|c|c|c|c|c|c|c|c|c|c|c|c|c|c|}
\hline Sample & 101 & 102 & 103 & 104 & 201 & 202 & 203 & 204 & 301 & 302 & 303 & 401 & 402 & 403 & 501 & 502 & 503 & 504 & 505 & 506 \\
\hline Min & fsp & fsp & fsp & fsp & fsp & fsp & fsp & fsp & fsp & fsp & fsp & fsp & fsp & fsp & fsp & fsp & fsp & fsp & fsp & fsp \\
\hline $\mathrm{SiO} 2$ & 61,89 & 62,61 & 61,85 & 61,51 & 62,56 & 61,5 & 62,42 & 62,21 & 59,87 & 61,92 & 60,9 & 61,57 & 61,05 & 61,13 & 60,31 & 60,97 & 61,8 & 61 & 61,93 & 60,76 \\
\hline $\mathrm{TiO} 2$ & 0 & 0 & 0 & 0 & 0 & 0 & 0 & 0 & 0 & 0 & 0 & 0 & 0 & 0 & 0 & 0 & 0 & 0 & 0 & 0 \\
\hline $\mathrm{A} 12 \mathrm{O} 3$ & 23,9 & 23,81 & 23,92 & 23,82 & 23,93 & 23,83 & 23,5 & 23,72 & 24,15 & 23,61 & 24,08 & 24,27 & 23,74 & 24,16 & 23,91 & 24,19 & 24,08 & 23,62 & 24,01 & 24,26 \\
\hline $\mathrm{Cr} 2 \mathrm{O} 3$ & 0 & 0 & 0 & 0 & 0 & 0 & 0 & 0 & 0 & 0 & 0 & 0 & 0 & 0 & 0 & 0 & 0 & 0 & 0 & 0 \\
\hline $\mathrm{Fe} 2 \mathrm{O} 3$ & 0 & 0 & 0 & 0 & 0 & 0 & 0 & 0 & 0 & 0 & 0 & 0 & 0 & 0 & 0 & 0 & 0 & 0 & 0 & 0 \\
\hline $\mathrm{FeO}$ & 0 & 0 & 0 & 0 & 0 & 0 & 0 & 0 & 0 & 0 & 0 & 0 & 0 & 0 & 0 & 0 & 0 & 0 & 0 & 0 \\
\hline $\mathrm{MnO}$ & 0 & 0 & 0 & 0 & 0 & 0 & 0 & 0 & 0 & 0 & 0 & 0 & 0 & 0 & 0 & 0 & 0 & 0 & 0 & 0 \\
\hline $\mathrm{MgO}$ & 0 & 0 & 0 & 0 & 0 & 0 & 0 & 0 & 0 & 0 & 0 & 0 & 0 & 0 & 0 & 0 & 0 & 0 & 0 & 0 \\
\hline $\mathrm{CaO}$ & 6,59 & 6,46 & 6,5 & 6,46 & 6,63 & 6,78 & 6,34 & 6,54 & 6,96 & 6,69 & 6,79 & 6,78 & 6,5 & 6,75 & 6,6 & 6,88 & 6,8 & 6,82 & 6,58 & 6,88 \\
\hline $\mathrm{Na} 2 \mathrm{O}$ & 7,14 & 7,3 & 7,3 & 7,19 & 7,18 & 7,15 & 7,24 & 7,14 & 7,18 & 7,01 & 7,15 & 7,04 & 7,16 & 7,21 & 6,96 & 6,73 & 7,08 & 7,1 & 6,92 & 7,17 \\
\hline $\mathrm{K} 2 \mathrm{O}$ & 0,48 & 0,52 & 0,56 & 0,51 & 0,41 & 0,53 & 0,58 & 0,5 & 0,34 & 0,49 & 0,45 & 0,47 & 0,55 & 0,51 & 0,53 & 0,52 & 0,56 & 0,6 & 0,62 & 0,51 \\
\hline Totals & 100,01 & 100,69 & 100,12 & 99,48 & 100,71 & 99,78 & 100,08 & 100,11 & 98,5 & 99,71 & 99,37 & 100,13 & 99 & 99,76 & 98,31 & 99,28 & 100,32 & 99,14 & 100,06 & 99,58 \\
\hline Oxygens & 8 & 8 & 8 & 8 & 8 & 8 & 8 & 8 & 8 & 8 & 8 & 8 & 8 & 8 & 8 & 8 & 8 & 8 & 8 & 8 \\
\hline $\mathrm{Si}$ & 2,745 & 2,757 & 2,742 & 2,744 & 2,753 & 2,738 & 2,765 & 2,755 & 2,703 & 2,753 & 2,722 & 2,728 & 2,738 & 2,723 & 2,725 & 2,726 & 2,736 & 2,736 & 2,745 & 2,714 \\
\hline $\mathrm{Ti}$ & 0 & 0 & 0 & 0 & 0 & 0 & 0 & 0 & 0 & 0 & 0 & 0 & 0 & 0 & 0 & 0 & 0 & 0 & 0 & 0 \\
\hline $\mathrm{Al}$ & 1,25 & 1,236 & 1,25 & 1,253 & 1,241 & 1,251 & 1,227 & 1,238 & 1,285 & 1,238 & 1,269 & 1,268 & 1,255 & 1,269 & 1,273 & 1,275 & 1,257 & 1,249 & 1,255 & 1,277 \\
\hline $\mathrm{Cr}$ & 0 & 0 & 0 & 0 & 0 & 0 & 0 & 0 & 0 & 0 & 0 & 0 & 0 & 0 & 0 & 0 & 0 & 0 & 0 & 0 \\
\hline $\mathrm{Fe} 3$ & 0,001 & 0,001 & 0,001 & 0 & 0,002 & 0 & 0,001 & 0,001 & 0,004 & 0,001 & 0,002 & 0,003 & 0,001 & 0,002 & 0 & 0 & 0 & 0,001 & 0 & 0,001 \\
\hline $\mathrm{Fe} 2$ & 0 & 0 & 0 & 0 & 0 & 0 & 0 & 0 & 0 & 0 & 0 & 0 & 0 & 0 & 0 & 0 & 0 & 0 & 0 & 0 \\
\hline $\mathrm{Mn}$ & 0 & 0 & 0 & 0 & 0 & 0 & 0 & 0 & 0 & 0 & 0 & 0 & 0 & 0 & 0 & 0 & 0 & 0 & 0 & 0 \\
\hline $\mathrm{Mg}$ & 0 & 0 & 0 & 0 & 0 & 0 & 0 & 0 & 0 & 0 & 0 & 0 & 0 & 0 & 0 & 0 & 0 & 0 & 0 & 0 \\
\hline $\mathrm{Ca}$ & 0,313 & 0,305 & 0,309 & 0,309 & 0,313 & 0,324 & 0,301 & 0,31 & 0,337 & 0,319 & 0,325 & 0,322 & 0,312 & 0,322 & 0,32 & 0,329 & 0,322 & 0,328 & 0,312 & 0,329 \\
\hline $\mathrm{Na}$ & 0,614 & 0,623 & 0,628 & 0,622 & 0,613 & 0,617 & 0,622 & 0,614 & 0,628 & 0,604 & 0,619 & 0,605 & 0,623 & 0,622 & 0,609 & 0,583 & 0,608 & 0,617 & 0,595 & 0,621 \\
\hline K & 0,027 & 0,029 & 0,031 & 0,029 & 0,023 & 0,03 & 0,033 & 0,028 & 0,02 & 0,028 & 0,025 & 0,026 & 0,031 & 0,029 & 0,031 & 0,03 & 0,032 & 0,034 & 0,035 & 0,029 \\
\hline Sum & 4,95 & 4,951 & 4,962 & 4,956 & 4,944 & 4,96 & 4,948 & 4,946 & 4,976 & 4,943 & 4,964 & 4,952 & 4,961 & 4,967 & 4,958 & 4,943 & 4,955 & 4,965 & 4,942 & 4,972 \\
\hline
\end{tabular}


ANEXO 03

\author{
MAPA GEOLÓGICO \\ E \\ MAPA DE PONTOS
}




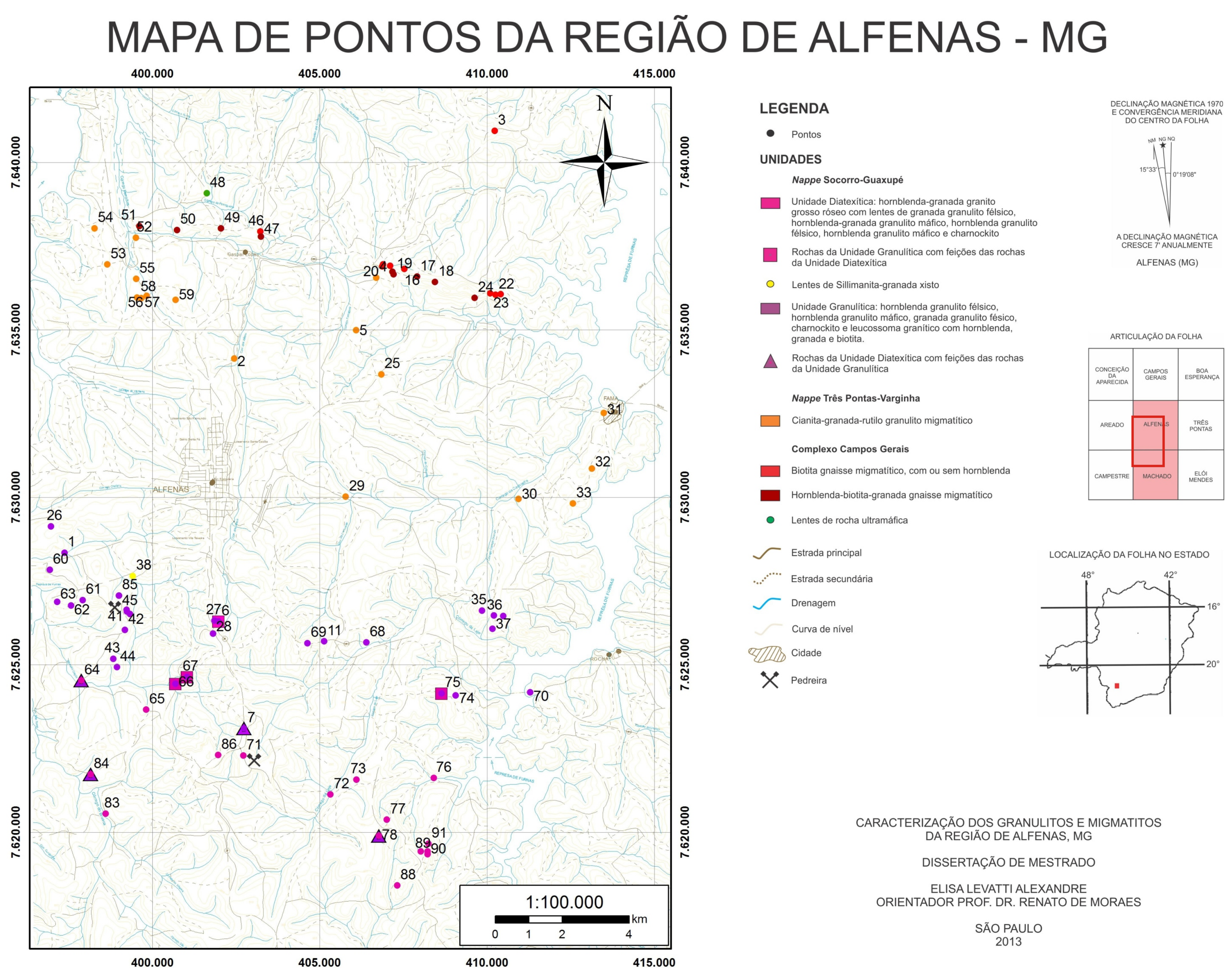




\section{MAPA DE GEOLÓGICO DA REGIÃO DE ALFENAS - MG \\ 400.000}

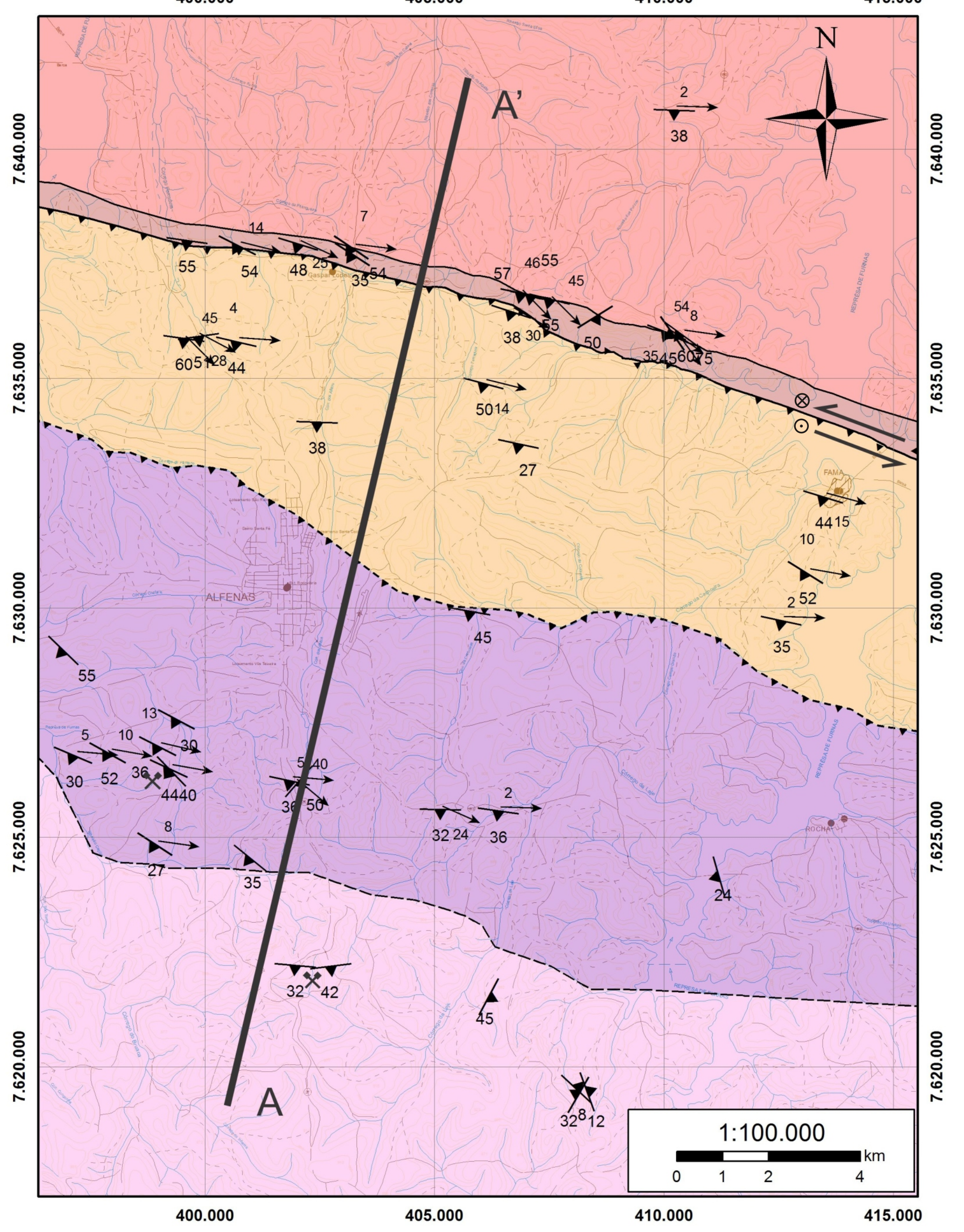

\section{LEGENDA}

UNIDADES

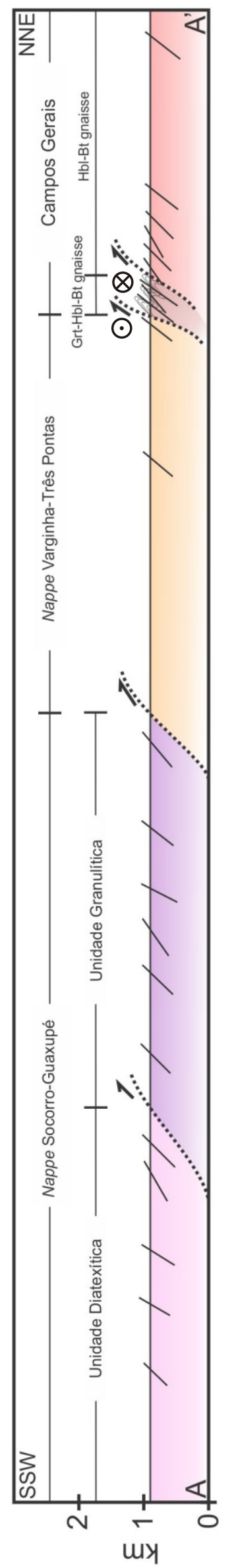

Nappe Socorro-Guaxupé

Unidade Diatexitica: hornblenda-granada granito
grosso róseo com lentes de granada granulito félsico, hornblenda-granada granulito máfico, hornblenda granulito homblenda granulito márico $\mathrm{e}$

Unidade Granulitica: hornblenda granulito félsico,
hornblenda granulito máfico, granada granulito fésico, hornblenda granulito máfico, granada granulito fésico,
charnockito e leucossoma granitico com hornblenda, granada e biotita.

Nappe Três Pontas-Varginha

$\square$ Cianita-granada-rutilo granulito migmatítico

Complexo Campos Gerais

$\square$ Biotita gnaisse migmatitico, com ou sem hornblenda

$\square$ Hornblenda-biotita-granada gnaisse migmatitico

$\frown$ Estrada principal

Estrada secundária

$\frown$ Drenagem

$$
\text { Curva de nivel }
$$

UII Cidade

$X$ Pedreira

MAPA

- Pontos

Falha de empurrão observada

Falha de empurrão inferida

Contato geológico observado

.... Contato geológico inferido

A' Linha do perfil (A-A')

${ }^{40}$ Foliação principal

Lineação de extiramento

$\checkmark$ Zona de cisalhamento

$\odot \otimes$ Componente vertical SEÇÃO GEOLÓGICA

‘** Falha de empurrão

Contato geológico inferido

Traço da foliação

$\odot \otimes$ Componente horizontal

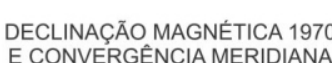
DO CENTRO DAFOLHA

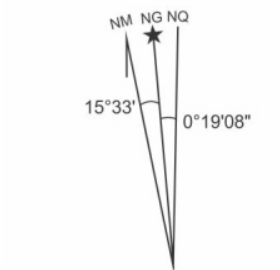

ADECLINACÃO MAGNETICA
CRESCE T'ANUALMENTE ALFENAS (MG)

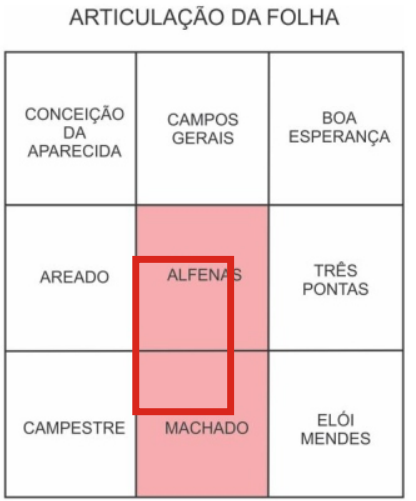

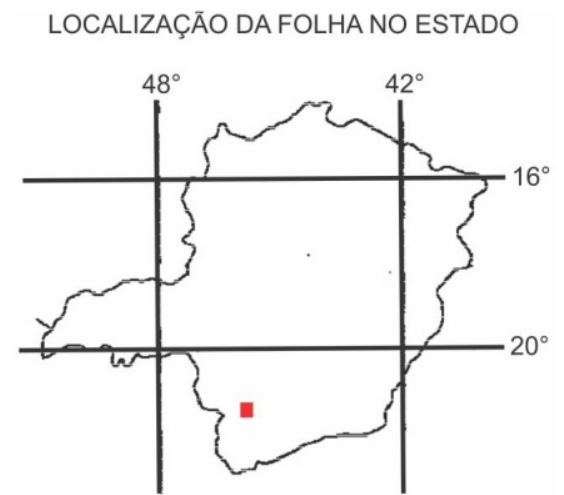

CARACTERIZAÇÃO DOS GRANULITOS E MIGMATITOS DA REGIÃO DE ALFENAS, MG DISSERTAÇÃO DE MESTRADO ELISA LEVATTI ALEXANDRE ORIENTADOR PROF. DR. RENATO DE MORAES SÃO PAULO 